\title{
RUPTURAS E ENCONTROS
} desafios da Reforma Psiquiátrica brasileira

Silvio Yasui

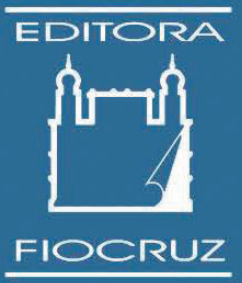




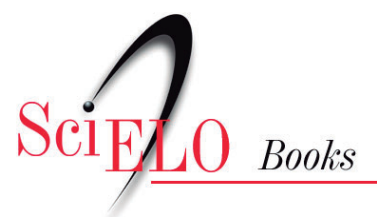

\title{
Rupturas e encontros desafios da reforma psiquiátrica brasileira
}

\author{
Silvio Yasui
}

\section{SciELO Books / SciELO Livros / SciELO Libros}

YASUI, S. Rupturas e encontros: desafios da reforma psiquiátrica brasileira [online]. Rio de Janeiro: Editora FIOCRUZ, 2010, 190 p. Loucura \& Civilização collection. ISBN 978-85-7541-362-3. https://doi.org/10.7476/9788575413623.

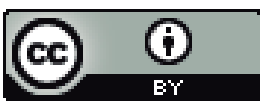

All the contents of this work, except where otherwise noted, is licensed under a Creative Commons Attribution 4.0 $\underline{\text { International license. }}$

Todo o conteúdo deste trabalho, exceto quando houver ressalva, é publicado sob a licença Creative Commons Atribição $\underline{4.0}$.

Todo el contenido de esta obra, excepto donde se indique lo contrario, está bajo licencia de la licencia Creative Commons Reconocimento 4.0. 


\section{RUPTURASE ENCONTROS}

desafios da Reforma Psiquiátrica brasileira 


\title{
FUNDAÇÃO OSWALDO CRUZ
}

Presidente

Paulo Gadelha

Vice-Presidente de Ensino, Informação e Comunicação

Maria do Carmo Leal

\author{
EDITORA FIOCRUZ \\ Diretora \\ Maria do Carmo Leal \\ Editor Executivo \\ João Carlos Canossa Mendes \\ Editores Científicos \\ Nisia Trindade Lima e Ricardo Ventura Santos \\ Conselho Editorial \\ Ana Lúcia Teles Rabello \\ Armando de Oliveira Schubach \\ Carlos E. A. Coimbra Jr. \\ Gerson Oliveira Penna \\ Gilberto Hochman \\ Joseli Lannes Vieira \\ Ligia Vieira da Silva \\ Maria Cecilia de Souza Minayo
}

Coleção Loucura \& Civilização

Editor Responsável: Paulo Amarante 
Loncura \& Civilização

\section{RUPTURAS EENCONTROS}

desafios da Reforma Psiquiátrica brasileira

Silvio Yasui

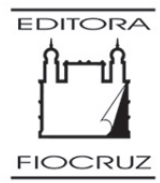


Copyright (C) 2010 do autor

Todos os direitos desta edição reservados à

FUNDAÇÃO OSWALDO CRUZ / EDITORA

Capa e projeto gráfico

Guilherme Ashton

Editoração eletrônica

Daniel Pose Vazquez

Revisão

M. Cecilia G. B. Moreira

Normalização de referências

Clarissa Bravo

Catalogação na fonte

Centro de Informação Científica e Tecnológica

Biblioteca da Escola Nacional de Saúde Pública Sergio Arouca

Y29

Yasui, Silvio

Rupturas e Encontros: desafios da Reforma Psiquiátrica brasileira. / Silvio Yasui. - Rio de Janeiro: Editora FIOCRUZ, 2010.

192 p., il. (Coleção Loucura \& Civilização)

ISBN: 978-85-7541-195-7

1. Reforma dos Serviços de Saúde. 2. Serviços de Saúde Mental. 3. Participação Comunitária. 4. Políticas Públicas. 5. Transtornos Mentais - Psicologia. I. Título.

CDD - 22.ed. - 362.2

2010

EDITORA FIOCRUZ

Av. Brasil, $4036-1^{\circ}$ andar

sala 112 - Manguinhos

21040-361 - Rio de Janeiro - RJ

Tel.: (21) 3882-9039 e 3882-9007

Telefax: (21) 3882-9006

editora@fiocruz.br

www.fiocruz.br/editora 
Morte e Vida Severina

$O$ retirante explica ao leitor quem é e a que vai

- O meu nome é Severino, não tenho outro de pia.

Como há muitos Severinos, que é santo de romaria, deram então de me chamar

Severino de Maria;

Mais isso ainda diz pouco

Somos muitos Severinos iguais em tudo na vida:

morremos de morte igual, mesma morte severina: que é a morte de que se morre de velhice antes dos trinta, de emboscada antes dos vinte de fome um pouco por dia (de fraqueza e de doença é que a morte severina ataca em qualquer idade, $e$ até gente não nascida). Mas, para que me conheçam melhor Vossas Senhorias e melhor possam seguir a história de minha vida, passo a ser o Severino que em vossa presença emigra.

João Cabral de Melo Neto 


\section{SUMÁRIO}

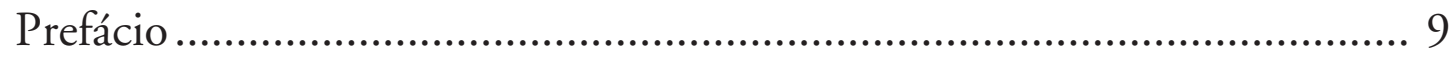

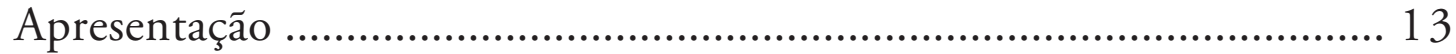

1. Movimento Social e Política Pública .................................................. 25

2. A Reforma Psiquiátrica e a Transição Paradigmática ........................... 75

3. Caps: estratégia de produção de cuidados ........................................ 113

4. Plantadores de Sonhos: a Reforma Psiquiátrica é um

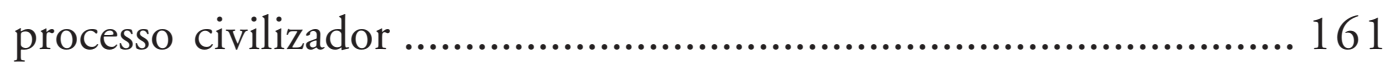

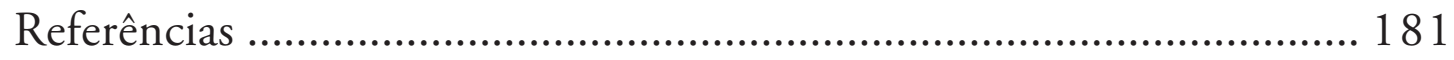




\section{PREFÁCIO}

Aqui a vida é Severina, e a loucura também!

Silvio Yasui é o nosso Severino sobrevivente, na descrição do mundo da loucura no Brasil, tomando recortes de diferentes lugares por onde passou, em narrativas de rara delicadeza e acuidade.

"Severino foi à busca do mar e encontrou a pobreza, a morte, a dor, mas também a esperança no espetáculo da vida”. E é de esperança que vamos falar doravante, nos capítulos muito bem articulados deste livro, que retratam a trajetória do autor e sua visão particular da Reforma Psiquiátrica brasileira com tal cuidado que nos faz viajar junto, tal o seu rigor narrativo. Sempre ancorado na crítica leitura de uma bibliografia disponível e, sobretudo, na sua experiência como protagonista de diferentes experiências em instituições psiquiátricas e de saúde mental no Brasil.

Lembro Silvio, quase menino, recém-formado, um bravo psicólogo a liderar um grupo de psicólogos ainda mais jovens, num programa de aprimoramento técnico no velho hospício do Juqueri. Transformou algumas coisas, lutou sempre. Lutou tão bravamente que o expulsaram de lá, nos fins dos anos 80 .

A brutalidade com que humanos subjugam humanos a condições vis, utilizando-se de argumentos, ora 'científicos', ora tutelares, para excluir a desrazão humana da cena principal, escondendo-a no porão, sensibilizou Silvio desde sempre a querer transformar o seu mundo de referência. A excitação pela possibilidade concreta de mudar a história talvez seja a maior regularidade na sua trajetória. 
Seu comportamento ético o levou até a rua Itapeva, 700, onde o acolhemos. Coube a mim entrevistá-lo e convocá-lo para se juntar aos que davam sentido à ideia do primeiro Centro de Atenção Psicossocial (Caps) Luiz Cerqueira, na Bela Vista, em São Paulo, que, por oportunidade, desejo e destino, me coube começar. Ali encontrou Jairo Goldberg, Sandra Fischetti, Nerse Reparch, Jonas Melmann, Carlos Videira, Ana Luiza Aranha, Sonia Barros, Adalberto, Sergio Urquiza, Tiana, Emiron e tantos outros e outras que fizeram e fazem real aquele sonho.

Ali pude acompanhar a sua sensibilidade clínica e de reabilitação psicossocial, plenamente articuladas. Seu violão bem afinado atraía pessoas, harmonizava espíritos, estabilizava delírios e alucinações, que o seu estilo zen de escuta tratava de ouvir e decifrar, para transformar temores em modos de viver a vida.

Estivemos juntos na primeira iniciativa de aproximar "fazejamento" e "pensação", como sempre quis o nosso David Capistrano, descrevendo, avaliando e produzindo teoria em serviço comunitário de saúde mental no país.

"Avaliação de serviço de atenção médico-psicossocial a usuários de sistema de saúde no município de São Paulo", 1990, foi um projeto de pesquisa financiada pelo Banco Mundial para avaliar serviços de saúde. Abrigado no Departamento de Medicina Preventiva da Faculdade de Medicina da Universidade de São Paulo (FM-USP), foi também a chance de conhecer outro Silvio Yasui, arguto e persistente indagador de métodos e técnicas de investigação que nos fizessem desvendar os mistérios de uma prática recente que tanto nos inquietava: lidar com a loucura fora do manicômio. O dilema 'quali-quanti' nos motivava ao debate, nas sessões noturnas, nas jornadas estendidas de trabalho de um técnico que não se satisfazia com as atividades assistenciais que estavam prescritas no seu contrato de trabalho e dedicava $o$ tempo livre ao desafio do conhecimento. A vocação docente-assistencial desse Caps sempre o colocou no lugar de mestre-aprendiz, acolhendo, compartindo, aprendendo, ensinando...

A atitude política de não se curvar ao estabelecido, participando de todas as iniciativas culturais, quer em eventos, quer em escritos, demonstrando uma trajetória coerente em defesa dos direitos humanos dos que sofrem com transtornos mentais, testemunhei muitas vezes. E essas iniciativas parecem ter estimulado muitas das questões arqueologicamente desenvolvidas neste texto. 
O encontro com Paulo Amarante, autor antimanicomial brasileiro dos mais profícuos, seu orientador de doutorado na Escola Nacional de Saúde Pública Sergio Arouca (Ensp), originando este livro tão oportuno, somente potencializou uma corrente de documentação do que vem se constituindo como movimento da Reforma Psiquiátrica brasileira, para a qual o Laboratório de Estudos e Pesquisas em Saúde Mental e Atenção Psicossocial da Fundação Oswaldo Cruz (Laps/Fiocruz) pacientemente amealha signos e sinais do que aconteceu no país, em tempos recentes, num esforço singular do seu criador. Agrega desta vez um olhar oriental e paulistano na construção de uma episteme que nos faz compreender encontros... rupturas... movimentos... políticas... práticas, tudo o que faça sentido na decifração de um movimento sem precedentes, em sua descontinuidade e persistência, na história brasileira.

O horizonte ético-político e estético desse processo civilizatório irreversível em que se constitui a Reforma Psiquiátrica brasileira encontra neste trabalho uma sistematização irrepreensível. É um autor maduro, professor da Universidade Estadual Paulista (Unesp) de Assis, que tem ensinado ao país como conduzir, a um só tempo, um trabalho acadêmico rigoroso e socialmente engajado, que o faz consistente no seu percurso teórico-técnicopolítico, o qual ele, generosamente, nos expõe à leitura.

O texto é precioso, denso e nos traz uma epistemologia da saúde mental brasileira, desde sua constituição, que não faz muito, até o tempo presente. Com o seu estilo firme e delicado, denuncia o mundo degradado e aviltante das instituiçõos psiquiátricas. Mas não fica na lamentação. Vai à luta e nos traz experiências construídas com o seu envolvimento pessoal, que nos cativa pelo que de verdadeiro pode espelhar para seus leitores.

Não se iludam quando ele nos alerta para uma abordagem exploratória sobre a Reforma Psiquiátrica. Como Simão Bacamarte, o inesquecível alienista de Machado de Assis, ele percebe a distinção entre a ilha e o oceano. Faznos ver o quanto é precoce qualquer juízo de valor que se possa fazer sobre práticas que apenas se iniciam, torpedeadas cotidianamente por diferentes grupos de interesse que se beneficiam ou se beneficiaram com o modelo asilo-manicomial. Construímos muito pouco, sabemos menos ainda, mas longe está a certeza dos apressados que se arvoram a defender modelos somente porque a inércia, a violência e o desrespeito à humanidade dos homens a instituíram como ciência e verdade. 
Há muito não temos à mão um arranjo de ideias e informações tão preciosas sobre a Reforma Sanitária brasileira, juntando o que já se escreveu sobre o tema e um testemunho sensível e particular de um militante antimanicomial que fez a Reforma por onde passou.

É tempo de celebração e leitura cuidadosa!

Ana Maria Fernandes Pitta

Professora e pesquisadora da Universidade Federal da Bahia; doutora em medicina preventiva pela Faculdade de Medicina da Universidade de São Paulo, com pós-doutorado em várias instituiçôes, entre elas, na Université de Montréal 


\section{APRESENTAÇÃO}

Dos muitos modos possíveis para se iniciar este livro, optei pelo caminho da poesia. Não sou nordestino, embora tenha por eles uma boa dose de admiração. O que tenho em comum com o início deste belo poema de João Cabral de Melo Neto é que sou filho de imigrantes e desejo me apresentar e introduzir este trabalho, que é fruto de uma tese de doutorado defendida em 2006, na Escola Nacional de Saúde Pública Sergio Arouca da Fundação Oswaldo Cruz (Ensp/Fiocruz), no Rio de Janeiro. Trata-se de um trabalho que tem o sentido de alguém que se movimenta, que transita, se desloca em busca de algo. Severino foi à busca do mar e encontrou a pobreza, a morte, a dor, mas também a esperança no espetáculo da vida; vendo-a desfiar seu fio que teimosamente se fabrica; vendo-a brotar em uma nova vida que explodia, ainda que franzina, ainda que de mais uma vida severina.

Já este que se apresenta ao leitor, com certeza, não tem esse suave dom da poesia, embora, para contar das coisas duras da vida, tenha a teimosa persistência dos que caminham. E como somos muitos os caminhantes nas veredas destes sertões, de muitas sinas e destinos - e se me permitem a ousadia e certo excesso, gostaria de apresentar o meu caminho, que resultou neste trabalho.

Comecei a me interessar pelo campo da saúde mental em 1976, no segundo ano do curso de Psicologia, quando tive a oportunidade de realizar um estágio voluntário em um hospital psiquiátrico. Conheci cedo a dura realidade da instituição psiquiátrica, dos maus-tratos, do abandono. Um dos primeiros pacientes com quem tive contato me marcou profundamente. Era um homem de uns 45 anos, com uma bela voz. Estava ensaiando uma pequena peça de teatro e solicitei a ele que fosse o narrador da história. 
De pronto, pegou o microfone, ajeitou-se e encantou a todos com uma possante e bonita voz. Perguntei-lhe o que fazia antes de ser internado, e ele me contou que era locutor de uma importante rádio de São Paulo. Estava quase um ano internado. $\mathrm{O}$ motivo: alcoolismo. Ele assegurava que estava bem, que já podia e queria sair, mas o "doutor" não autorizava. Soube, mais tarde, que esse era um procedimento comum nos hospitais psiquiátricos, manter os pacientes alcoolistas, pois, em abstinência, eram excelentes para as tarefas cotidianas do hospital e acabavam sendo utilizados como mão de obra barata. Percebi, com a peça de teatro, que aqueles a quem se nomeavam loucos, doidos, doentes mentais, eram pessoas interessantes, agradáveis, com histórias de vida intensas e, apesar das crises que apresentavam, vez ou outra, mantinham um contato pessoal e afetivo. E precisavam de pouco: serem reconhecidos e respeitados. Essa experiência marcou profundamente minha vida. Ainda que de uma forma não muito clara, decidi ali com o que gostaria de trabalhar.

Poucos anos após minha formatura, ao final de 1983, assumi a função de psicólogo no Departamento Psiquiátrico II, nacionalmente conhecido como Hospital Psiquiátrico de Juqueri (São Paulo). Meu primeiro contato foi com o diretor clínico do hospital, que me contava sobre os diferentes projetos que estavam iniciando, um pouco para me seduzir com um deles, chamado "Lar abrigado", que acabei por integrar. Aquele foi um importante encontro. Havia uma expectativa de diversos médicos para que eu fosse trabalhar com os residentes, aplicando testes projetivos e realizando psicoterapia nos pacientes por eles indicados, como forma de ampliar as discussões clínicas psiquiátricas. Embora pressionado, o diretor clínico sustentou minha escolha em trabalhar no "Lar abrigado'. Começava ali uma trajetória profissional, a qual me remeteria a construir/inventar uma forma diferente de atuar.

Aqueles eram tempos diferentes. Um governo estadual eleito democraticamente, um sanitarista como secretário da Saúde. Vários profissionais recém-contratados, imbuídos do espírito de trabalhar para mudar e transformar. O clima de mudança e participação estava presente na cena brasileira naqueles anos. Em 1984, houve a campanha das Diretas-Já, que resgatou nossa capacidade coletiva de participação em eventos políticos grandiosos. Depois, veio a eleição indireta de Tancredo Neves e a sua morte. Então, assumiu seu vice, José Sarney, dando início à Nova República. 
A lembrança mais viva que trago daqueles anos é a excitação pela possibilidade concreta de mudar a história: do lugar que trabalhava, de minha cidade, de meu estado, de meu país. Aquilo que antes era sonho parecia próximo, real e concreto. Eram os tempos da Constituinte. Os atores da Reforma Sanitária lutavam pela conquista do direito à saúde, pelo estabelecimento das diretrizes do Sistema Único de Saúde (SUS). Tempos da histórica $8^{\text {a }}$ Conferência Nacional de Saúde de 1986, que teve como consequência a realização, no ano de 1987, da I Conferência Nacional de Saúde Mental.

Tive a oportunidade de participar daquela Conferência de Saúde Mental e de presenciar, em seus bastidores, as articulações para a organização do II Congresso Nacional de Trabalhadores de Saúde Mental, realizado no mês de dezembro do mesmo ano, na cidade de Bauru, SP, em que participei ativamente. Um congresso também histórico pelo nascimento do Movimento da Luta Antimanicomial - marcado pelo lema "Por uma sociedade sem manicômios" e pela escolha do dia 18 de maio como o Dia Nacional da Luta Antimanicomial.

Todos esses eventos apontam para um importante processo que, iniciado no final dos anos 70, ganha impulso e legitimidade no início dos anos 80: a Reforma Psiquiátrica. Trata-se de um movimento de muitas faces: a das inovadoras experiências institucionais, dando seus primeiros passos; a da legitimidade como política pública, começando a ser assumida pelo Ministério da Saúde, com a I Conferência Nacional; a de movimento social, com o Movimento da Luta Antimanicomial, congregando diferentes atores, usuários, profissionais, familiares, simpatizantes.

Como sublinhei, havia naqueles anos um clima que nos convocava a participar ativamente das mudanças, nas diferentes dimensões de nossa existência.

Em 1987, deixei, compulsoriamente, o trabalho no Juqueri e comecei em um novo serviço de saúde mental que surgia naquele ano: o Centro de Atenção Psicossocial (Caps) Prof. Luiz da Rocha Cerqueira. Essa mudança marcou profundamente minha vida profissional.

Os primeiros meses de trabalho no Caps foram intensos. Assim como eu, vários outros profissionais estavam chegando e em condições parecidas: foram afastados de projetos em que se destacavam. Foi um espasmo autoritário de início do governo estadual. O Caps conseguiu ser o que é, apesar da 
política de precarização do trabalho na saúde, implementada naqueles dias. Porém, o que importava era que estávamos assumindo um importante projeto, colocando em prática a possibilidade de construir um serviço de cuidados às pessoas que apresentavam sofrimento psíquico, prescindindo do hospital psiquiátrico. Foi uma inesquecível experiência de construção coletiva.

Em 1989, foi publicado o primeiro livro da Coleção Saúdeloucura, da Editora Hucitec, que traz um texto de minha autoria, no qual realizo algumas reflexões sobre aqueles primeiros anos do Caps.

Em função do caráter inovador de nosso trabalho, fomos convidados a expô-lo em dezenas de eventos pelo país. Apresentávamos e discutíamos a possibilidade de se construir um novo serviço de saúde mental, não apenas em congressos oficiais e formais, mas em dezenas de encontros informais com as equipes de saúde de municípios. Guardo a agradável lembrança de horas e mais horas de conversas, de trocas de experiências, de certa sensação de estar semeando ideias sobre a possibilidade de transformação.

Esses convites tornaram-se mais intensos, a partir de 1992, com a 2a Conferência Nacional de Saúde Mental, a qual consolidou a política oficial de mudança assistencial. $\mathrm{O}$ trabalho que desenvolvíamos no Caps ganhou reconhecimento e legitimidade, transformando-se, assim como os Núcleos de Atenção Psicossocial (Naps) de Santos, em marcas de serviços de saúde transformadores.

Ao final de 1994, tomei uma importante decisão em minha vida e mudei-me para o interior de São Paulo. Em 1995, trabalhei como assessor de saúde mental da Unidade de Saúde Mental de Penápolis-SP, onde, juntamente com a equipe, reorganizamos o atendimento e implantamos um Caps. Por imperativos imponderáveis do destino, retomei um antigo projeto de dedicar-me à universidade e terminei o ano como docente da Universidade Estadual Paulista (Unesp) de Assis e como articulador regional das ações de saúde mental na Direção Regional de Saúde de Assis (DIR VIII).

Comecei esse trabalho criando um fórum regional de articuladores municipais de saúde mental, o Colegiado Regional de Saúde Mental. Além de ser um espaço para troca de experiências entre os diferentes profissionais, o colegiado possibilitou um reconhecimento, por parte dos gestores de saúde, da importância das açôes em saúde mental, das questôes e dificuldades inerentes ao nosso campo. Percorria os municípios da região, para dialogar com os profissionais, buscando contribuir para a construçãa/invenção de 
ações de saúde mental que rompessem com o tradicional modelo de atendimento centrado em consultas psiquiátricas ou psicológicas e mais nada além.

Mensalmente, participava do Colegiado Estadual de Saúde Mental, reunião realizada em São Paulo, junto com todos os articuladores das direções regionais. Foi um espaço para trocas e democratização das informações, em âmbito estadual. Também foi espaço onde se discutiam as supervisões de avaliação dos serviços de saúde mental, notadamente dos hospitais psiquiátricos, com vistas ao credenciamento junto ao SUS. Isso me possibilitou conhecer a realidade assistencial de praticamente todas as importantes cidades do estado de São Paulo. Pude perceber o quanto o processo da Reforma Psiquiátrica era distante da realidade de muitos profissionais. As questôes que encontrei em diversos lugares me remetiam ao tempo em que trabalhava no Juqueri: a internação como terapêutica exclusiva e compulsória; estruturas hierarquizadas e centralizadas na figura do médico; predominância do tratamento medicamentoso; intolerância em relação às crises dos pacientes; ausência de alternativas assistenciais e equipes queixosas, sempre prontas a culpabilizar o outro por suas 'carências'. Essas andanças me provocaram inúmeras questôes, especialmente no que se refere ao trabalho das equipes.

Enquanto atuava na Direção Regional de Saúde, desenvolvia atividades de docente na Unesp. Esta duplicidade durou entre outubro de 1995 e fevereiro de 2000, quando passei a me dedicar exclusivamente à universidade. Entretanto, não abandonei os trabalhos e a pesquisa no campo da saúde mental e da saúde coletiva, que continuo a desenvolver, especialmente por meio das atividades de supervisão de estágios dos alunos do curso de Psicologia, em serviços de saúde mental nos municípios de Assis e região.

Em 2002, ingressei no curso de doutorado em saúde pública na Ensp e defendi, em 2006, a tese que é o ponto de partida e a essência deste trabalho, a que ora o leitor tem acesso.

Espero não tê-lo cansado com esta extensa apresentação de minha biografia. Poupei-o de relatar outros tantos encontros (e desencontros) que produziram efeitos, sentidos, emoções, pensamentos, e constituem a matériaprima da minha existência. Matéria essencial para compreender o caminho que escolhi para este trabalho.

Heitor Villa-Lobos tornou famosa uma frase: "Faço músicas como quem manda um bilhete para a posteridade". Escrevo aqui sobre um processo 
social amplo e complexo, nomeado de Reforma Psiquiátrica, construído graças ao trabalho de centenas de protagonistas, de Severinos, como este que ousa assim escrever. Falar em processo é falar de algo que continua no tempo, que nos transcende. Quero fazer deste trabalho um legado para a posteridade, contando que "os nossos dias eram assim". ${ }^{1}$

Ao começar o doutorado, tinha em mente um projeto de pesquisa que se foi modificando, passando de uma pesquisa de campo para uma reflexão sobre diferentes temas da Reforma Psiquiátrica. O projeto, que inicialmente havido planejado, não contemplaria de forma satisfatória esses temas. Isso me levou a considerar a possibilidade de realizar tal tarefa em ensaios distintos, mas que convergem, cada qual a seu modo, para a conclusão sobre o processo civilizador da Reforma Psiquiátrica.

Para Tobar e Yalour (2001: 24), o ensaio

envolve uma tomada de posição diante de um tema ou objeto de meditação. Explicita a subjetividade de seu autor e o compromete. É um exercício crítico de procura, e o que se procura são maneiras novas de olhar as coisas. Por este motivo, o ensaio é sempre exploratório. Ensina a ver e convida a olhar de outra forma. Mas apenas consegue ver a paisagem quem transita pelo caminho ou a percorre.

Com este trabalho, tenho a humilde pretensão de convidar o leitor a olhar para a Reforma Psiquiátrica com os olhos de quem, há mais de vinte anos, tem trilhado os caminhos da saúde mental pública. A implantação da Reforma Psiquiátrica se intensificou nos anos 90, com novas instituições surgidas da capacidade de invenção dos atores sociais, especialmente os trabalhadores de saúde mental, os quais modificaram sua prática cotidiana, criando novos paradigmas assistenciais. Esse processo foi caracterizado não apenas por meio da luta pela transformação do campo da assistência, porém se estendia e compreendia a luta pela transformação da sociedade.

Ao longo de minha trajetória pelo campo e diante da complexidade e da amplitude desse processo social, questões foram me inquietando, provocando reflexôes. São questões exploratórias, afirmações provisórias, olhares que tentam não pecar pela miopia, mas revelam a narrativa de uma longa viagem compartilhada com muitas pessoas: inesquecíveis e inestimáveis companheiros de trabalho e estudo, que me ajudaram a tecer os fios desta história;

1 Referência à música “Aos nossos filhos” de Ivan Lins e Vítor Martins, cantada na voz de Elis Regina. 
autores clássicos e contemporâneos, com os quais dialoguei em insones noites, ora de angústia, ora de alegria reflexiva.

Companheiros de viagem que forjaram em minha alma as lentes com as quais enxergo a realidade. Freud e Marx estão na fonte e na origem de muitas dessas reflexões, inclusive por meio de outros autores que, de tantos, prefiro deixar para o leitor identificar ao longo dos ensaios. Autores, teorias e teses que, embora com tensões e contradições entre si, têm em comum o olhar crítico para a realidade social, para desconstruir, para explicitar, a fim de revelar o jogo de forças e poder que a constitui. Olhar crítico também em relação à produção da verdade científica e de sua implicação naquele jogo de forças e poder.

Isso marca um lugar político e ideológico norteador de minha prática profissional, de minha produção científica e da escolha de minhas referências teóricas. Confio na possibilidade de o homem viver mais autonomamente; ser sujeito de sua própria história, de seu desejo. Creio na possibilidade deste homem em construir uma sociedade mais democrática, socialmente mais justa, mais equânime e, ao mesmo tempo, acredito que este mesmo homem é o resultado das forças sociais, políticas, econômicas, culturais e desejantes que incidem sobre seu corpo, criam saberes e práticas que o sujeitam. É nesse confronto, ou nesse paradoxo entre ser sujeito e ser sujeitado, que criamos nossos projetos sobre o mundo, orientamos nossas ações, nos potencializamos ou desanimamos. O campo da saúde mental é constituído dessa matéria-prima, de conflito e de contradições. É o lugar do humano, demasiadamente humano.

Trata-se, portanto, de um estudo teórico-conceitual sobre a Reforma Psiquiátrica que efetuei, realizando uma ampla revisão e pesquisa bibliográfica. É um estudo teórico inspirado e articulado à minha prática profissional como trabalhador da saúde, como gestor da saúde mental, como supervisor institucional, como docente, como testemunha e atuante em um processo social amplo e complexo.

O conceito de processo social complexo é central na análise que pretendo empreender. Rotelli, Leonardi e Mauri (2001) utilizam-no para caracterizar a desinstitucionalização italiana e diferenciá-la da ocorrida na Europa e nos Estados Unidos, que, para eles, reduziu-se a uma 'desospitalização', motivada especialmente pela necessidade de racionalização financeira e administrativa. Eles afirmam: 
A verdadeira desinstitucionalização em Psiquiatria tornou-se na Itália um processo social complexo que tende a mobilizar como atores os sujeitos sociais envolvidos, que tende a transformar as relações de poder entre os pacientes e as instituições, que tende a produzir estruturas de Saúde Mental que substituam inteiramente a internação no Hospital Psiquiátrico e que nascem da desmontagem e reconversão dos recursos humanos e materiais que estavam ali depositados. (Rotelli, Leonardi \& Mauri 2001: 18)

Esse processo envolve, ainda, desinstitucionalizar o paradigma psiquiátrico, ou seja, reconstruir a complexidade do objeto, desmontando o conceito de doença, retomando o contato com a existência e o sofrimento do sujeito e sua ligação com o corpo social, não mais para curar, mas para a produção de vida, de sentidos, de sociabilidade e de espaços coletivos de convivência.

Amarante (2003) toma emprestado esse conceito e aplica-o ao processo de transformação da assistência em saúde mental, isto é, a Reforma Psiquiátrica. Embora a palavra 'reforma' não contemple a amplitude de tal processo, podendo ser associada a mudanças meramente superficiais, ou mudanças para não mudar, é um conceito consagrado que guarda estreita e profunda ligação histórica com o Movimento Sanitário e a Reforma Sanitária. Em comum, ideais e utopias, problemas e dilemas, contradições e desafios. Ao analisar a prática científica da Reforma Sanitária, Dâmaso (1995: 73) ressalta, a propósito das limitações do termo 'reforma': "Em que pese a sua ameaça reformista, o conceito de Reforma Sanitária tem, todavia, um sentido "forte": trata-se de conceber e fazer da saúde o fundamento revolucionário de uma transformação setorial, com ressonâncias estruturais sobre o conjunto da sociedade".

O termo 'forte' é igualmente empregado por Rotelli, Leonardi e Mauri (2001) para definir um serviço inteiramente substitutivo à internação, que responde à complexidade das necessidades, antes absorvidas pelo asilo psiquiátrico. Nessa perspectiva, pretendo contribuir para a construção de uma conceituação 'forte' da Reforma Psiquiátrica, ou seja, superar a ideia de um reformismo simplista, restrito a uma mudança técnica ou administrativa. Tratase de tomar a Reforma Psiquiátrica no sentido de uma transformação que impacta e ressoa na sociedade. É essencialmente um processo que vai se constituindo em estreita vinculação com seu tempo histórico, com os seus atores, nos territórios e locais em que está inserido, concretiza-se, ganha materialidade. Meu intento é o de construir uma conceituação dinâmica desse processo 
amplo e complexo. Fazendo referência a um conhecido poema de Antonio Machado, ${ }^{2}$ este é um caminho que se faz, desfaz e se refaz, caminhando.

Assim, Amarante caracteriza a Reforma Psiquiátrica como um processo social complexo que abrange quatro dimensões essenciais: dimensão teóricoconceitual ou epistemológica, técnico-assistencial, jurídico-política e sociocultural. São essas dimensões que comporão o eixo deste trabalho. Neste momento histórico que atravessamos, de ampliação dos serviços, de consolidação da Reforma Psiquiátrica como política pública, em um contexto social, político e econômico desfavorável à implementação de políticas sociais redistributivas, cada dimensão apresenta um conjunto de desafios que se faz urgente e necessário enfrentar. Em cada capítulo, procurei elaborar um ensaio buscando caracterizar os desafios e discuti-los, refletindo sobre as rupturas com modelos hegemônicos e sobre a construção de novos modos de cuidar, de novos paradigmas, do sonho de uma nova sociedade. Desse sonho decorre minha hipótese final do conceito 'forte' da Reforma Psiquiátrica: ela é um processo civilizador.

No primeiro capítulo, intitulado "Movimento social e política pública", sugiro uma pequena alteração, renomeando a dimensão jurídico-política como dimensão política. A ênfase no termo 'político' visa a destacar exatamente as tensões e conflitos decorrentes das ações que provocam e interrogam a relação entre Estado e sociedade, e que produzem resultados nem sempre ideais, por vezes negociados, como, por exemplo, todo o processo envolvido até a aprovação da lei 10.216. Ações encarnadas em protagonistas que objetivam uma mudança para o lugar social da loucura, para a diferença. Trata-se, enfim, de uma luta política para uma transformação social. O texto retoma o percurso histórico da Reforma Psiquiátrica, destacando a dimensão política desse processo e de seus protagonistas.

No segundo capítulo, "A Reforma Psiquiátrica e a transição paradigmática", focalizo o tema da dimensão epistemológica, buscando estabelecer uma relação e um paralelo entre a transição paradigmática das ciências, tal como proposto por diversos autores críticos da racionalidade científica moderna, e a ruptura epistemológica em relação à psiquiatria tradicional presente nos

\footnotetext{
2 "Caminante, son tus huellas / el camino y nada más; / Caminante, no hay camino, / se hace camino al andar. / Al andar se hace el camino, / y al volver la vista atrás / se ve la senda que nunca / se ha de volver a pisar. / Caminante no hay camino / sino estelas en la mar" (Proverbios y cantares - XXIX. Disponível em: <www.geocities.com/Athens/Delphi/5205/machado.htm>. Acesso em: 20 out. 2005).
} 
princípios da Reforma Psiquiátrica. Ao propor a construção de um novo olhar sobre a loucura, sobre o sofrimento psíquico, a reforma aponta para a construção de novos saberes e de novas práticas sociais, em um processo semelhante à produção de conhecimento, a partir de novos paradigmas sobre a verdade científica.

O terceiro capítulo, "Caps: estratégia de produção de cuidados", trata de uma reflexão sobre a dimensão técnico-assistencial, intimamente relacionada com a dimensão epistemológica. Proponho-me cartografar e refletir sobre os principais conceitos que norteiam a produção de cuidados dos Caps, aqui entendido não apenas como um serviço, mas como uma estratégia que produz uma ruptura com o modelo assistencial hegemônico.

O quarto e último capítulo, "Plantadores de sonhos: a Reforma Psiquiátrica é um processo civilizador”, pretende contemplar a dimensão sociocultural que se refere às questóes relativas à construção de um novo lugar social para a loucura, por meio da transformação do seu imaginário e de suas relaçôes com a sociedade. E pretendo fazê-lo apontando para dois aspectos dessa dimensão: o dispositivo utilizado para provocar essa transformação, que são as açôes culturais e artísticas produzidas por todos os envolvidos neste campo - usuários, familiares, profissionais, estudantes - e pelos artistas que, historicamente, têm colocado em suas obras referências diretas à loucura. $\mathrm{O}$ outro aspecto, que se coloca no horizonte dessa dimensão e que articula todas as outras: a utopia de mudar o mundo. A Reforma Psiquiátrica, por sua complexidade, diversidade e abrangência, não pode e não deve ser confundida com uma modificação na estrutura dos serviços de saúde ou de mudança nas instituições. Sua natureza é mais ampla. A Reforma Psiquiátrica é um processo civilizador.

$\mathrm{Na}$ tentativa de representar graficamente a inter-relação entre as quatro dimensões, apresento a Figura 1, inspirada na faixa de Moebius. Se tomarmos uma tira simples, na forma de um cinto, veremos que esta possui duas superfícies distintas (uma interna e outra externa). Se, antes de fecharmos o cinto, produzirmos uma torção de $180^{\circ}$ (Figura 2) teremos a fita de Moebius, que tem uma única superfície, ou seja, se a percorremos, estaremos sempre na mesma face. Podemos ir de um ponto de um 'lado' da faixa a qualquer ponto do 'outro' lado, por meio de um caminho contínuo sem nunca perfurar a superfície nem passar pela fronteira. A faixa de Moebius possui esta interessante propriedade: não tem um lado de 'dentro' e outro de 'fora', 
nem um lado 'direito' e seu 'avesso'. Segundo Granan-Lafont (1988), é sobre esses paradoxos que Lacan, responsável por trazer tal topologia do campo da matemática para a psicanálise, utiliza essa figura como apoio para diferentes usos, seja para reunificar dois conceitos separados, seja para representar um tipo de relação entre duas noções, como, por exemplo, a relação entre significante-significado.

$\mathrm{Na}$ figura que apresento, produzi quatro torçôes na faixa (o que a descaracteriza como uma faixa moebiana que necessita sempre de um número de torções ímpar), de maneira a representar as quatro dimensões da Reforma Psiquiátrica, compondo um único processo, no qual não há o 'fora' ou o 'dentro'. As dimensões se imbricam e se mesclam, formando uma mesma figura. Para compreender a complexidade do processo da Reforma Psiquiátrica, é necessário percorrer a faixa, transitando por todas as dimensões.

Figura I - Representação gráfica das quatro dimensões da Reforma Psiquiátrica, inspirada na faixa de Moebius

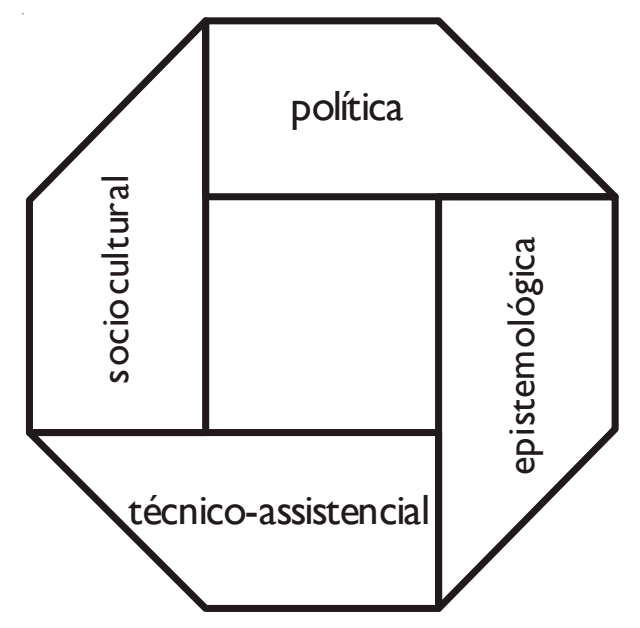

Figura 2 - Torção de $180^{\circ}$
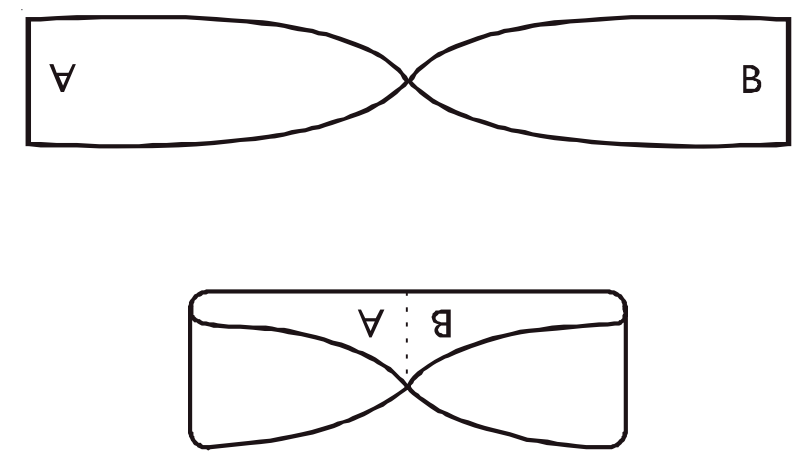
Finalizo esta apresentação explicitando que, dentre os diversos interlocutores imaginários que me acompanharam, na redação deste trabalho, os profissionais que estão na linha de frente dos serviços de saúde mental foram os mais constantes. Assim, tenho um claro desejo de que a leitura deste livro possa se transformar em um momento de diálogo entre este autor e esses profissionais que têm sob sua responsabilidade uma imensa tarefa: a de concretizar, de dar corpo e alma a este processo complexo de transformação. 


\section{1 \\ MOVIMENTO SOCIAL E POLÍTICA PÚBLICA}

Há aqueles que lutam um dia; e por isso são bons. Há aqueles que lutam muitos dias; e por isso são muito bons.

Há aqueles que lutam anos; esão melhores ainda. Porém há aqueles que lutam toda a vida; esses são os imprescindiveis.

Bertolt Brecht

Este primeiro capítulo pretende abordar a dimensão jurídico-política. Amarante $(1999,2003)$ a define como revisão das legislaçôes no que se referem aos conceitos e noções que relacionam a loucura à periculosidade, irracionalidade, incapacidade e irresponsabilidade civil. Esta dimensão busca rediscutir e redefinir as relaçóes sociais e civis em termos de cidadania, de direitos humanos e sociais. Proponho aqui uma pequena alteração, renomeando-a como dimensão política. Busco com esta proposta destacar o conceito político, ressaltando as tensões e conflitos decorrentes das ações produzidas pela Reforma Psiquiátrica, as quais provocam e interrogam a relação entre Estado e sociedade. Tais ações mostram-se encarnadas em protagonistas que constroem um conjunto de princípios e proposições, articuladas a um processo que tem como resultado mudanças no aparato jurídico do Estado. Processo que também ativa e muda os atores sociais, cria contradições, inventa instituiçōes de cuidado, transforma as políticas municipais, provoca as universidades. Enfim, implica todos, em uma utopia ativa de transformação social que se faz e refaz cotidianamente. Trata-se, dessa forma, de uma luta política para uma transformação social.

A relação entre os termos 'reforma', 'psiquiatria', 'política' e 'Estado' remontam ao ato fundador da psiquiatria, produzido no contexto da Revolução Francesa por um de seus líderes políticos: Philippe Pinel. Delgado 
(1992) destaca que, durante o século XIX, vamos encontrar várias iniciativas de reforma da psiquiatria, com o objetivo de constituir uma direção mais científica aos estabelecimentos especializados. No Brasil, Machado e colaboradores (1978) analisam a criação do Hospício de Alienados Pedro II, marco inaugural da psiquiatria no país, como parte integrante de um projeto normalizador da medicina para a sociedade brasileira. Em 1830, os médicos, para solucionar o problema dos alienados abandonados à sua sorte pelas ruas da cidade, ou internados indevidamente no Hospital Santa Casa, lançam o lema "aos loucos o hospício", que obtém êxito com decreto de 18 de julho de 1841, ato da maioridade do Imperador, criando o Hospício de Alienados Pedro II, na praia Vermelha, no Rio de Janeiro.

Já no final do século XIX e início do século XX, Cunha (1988) enfatiza o intenso e rápido processo de urbanização e industrialização da então Província de São Paulo. Tal processo produziu pressões junto ao poder público para resolver o problema dos loucos que lotavam as cadeias da cidade e resultou na criação, em 1898, do Hospício de Juqueri, construído por Franco da Rocha, após uma longa negociação política. Ambos os hospícios cumpriram uma função social de legitimar a exclusão de indivíduos ou setores sociais não enquadráveis, indisciplinados.

Nos anos 20 e 30, vamos encontrar, conforme aponta Costa (1981), a Liga Brasileira de Higiene Mental, apresentando seu ideal eugênico como projeto político para a sociedade brasileira. Delgado (1992) aponta para a consolidação da estrutura manicomial do Estado, na era Vargas, como parte de um projeto reformista. Resende (1987) afirma que a palavra 'exclusão' é a que melhor define e sintetiza a política de assistência em saúde mental ao longo de boa parte do século XX. Todos esses autores, e muitos outros aqui não citados, analisam e evidenciam a estreita e íntima relação entre o hospício e as demandas e necessidades oriundas dos processos econômicos, políticos e sociais da cidade e da sociedade, na qual estão inseridos.

Foucault (1979), em uma entrevista que se encontra nas primeiras páginas do livro Microfisica do Poder, apresenta os motivos que o levaram a escrever História da Loucura, afirmando que um dos problemas que lhe interessavam era o do estatuto político da ciência e as funções ideológicas que podia difundir. Resumido em duas palavras: a relação entre poder e saber. Para ele, as relaçôes entre as ciências, como a física teórica ou a química orgânica, com as estruturas políticas e econômicas da sociedade não são tão 
claras quanto com o saber psiquiátrico, pois seu perfil epistemológico é pouco definido e a sua prática está ligada a uma série de instituições, de exigências econômicas imediatas e de urgências políticas de regulamentações sociais.

Se, desde os seus primórdios, a psiquiatria vem sendo reformada, sofrendo mudanças que se articulam com contextos políticos, econômicos, sociais e culturais, qual a diferença da proposta da Reforma Psiquiátrica de que trataremos neste trabalho? O que apresentarei neste e nos próximos capítulos se diferencia das outras reformas, porque se refere a um processo social complexo, caracterizado por uma ruptura dos fundamentos epistemológicos do saber psiquiátrico, pela produção de saberes e fazeres que se concretizam na criação de novas instituições e modalidades de cuidado e atenção ao sofrimento psíquico e que buscam construir um novo lugar social para a loucura. Esse processo situa-se, no caso brasileiro, no contexto histórico e político do renascimento dos movimentos sociais e da redemocratização do país, na segunda metade dos anos 70 .

A Reforma Psiquiátrica brasileira é um amplo campo heterogêneo composto por distintas dimensões. É, sobretudo, um processo que traz as marcas de seu tempo. Não é possível compreendê-la sem mencionar suas origens, como movimento social, como uma articulação de atores da sociedade civil que apresentaram suas demandas e necessidades, assumindo seu lugar de interlocutor, exigindo do Estado a concretização de seus direitos. São ações que pressupõem verbalização e afirmação de interesses, disputas, articulações, conflitos, negociações, propostas de novos pactos sociais. Ações que acreditam na possibilidade da construção de uma nova sociedade ("um outro mundo é possível"). ${ }^{3}$ Acreditam na possibilidade de transformar a sociedade, mudar as relações sociais, possibilitar a participação nos bens econômicos, culturais, construir um mundo mais justo, mais equânime, mais livre. Acreditam em milagres, no sentido atribuído por Hannah Arendt ao termo.

No sombrio contexto de meados do século XX, que apresenta, de um lado, a traumática experiência de regimes totalitários e, de outro, a existência dos meios para o total extermínio da Humanidade, Arendt (2004) afirma que o sentido da política é a liberdade, pois se baseia na pluralidade dos homens, na convivência entre diferentes. A autora postula que a política

\footnotetext{
3 Referência ao lema do Fórum Social Mundial.
} 
não surge 'no' homem, mas sim 'entre' os homens. Dessa forma, a liberdade e a espontaneidade dos diferentes homens são pressupostos necessários para o surgimento do espaço, onde só então se torna possível a política. Para ela, o homem é possuidor de um dom "extremamente maravilhoso e misterioso, de fazer milagres". Chama a esse dom, a essa aptidão, de agir. Arendt (2004: 43-4) sublinha:

É característico do agir a capacidade de desencadear processos, cujo automatismo depois parece muito semelhante ao dos processos naturais; é-lhe característico, inclusive, o poder impor um novo começo, começar algo novo, tomar iniciativa (...) O milagre da liberdade está contido nesse poder-recomeçar que, por seu lado, está contido no fato de que cada homem é em si um novo começo, uma vez que, por meio do nascimento, veio ao mundo que existia antes dele e vai continuar existindo depois dele.

Política é a convivência com o diferente, é agir em um mundo de interesses diversos, de conflitos, disputas, alianças. Exercitar a liberdade é correr os riscos de viver a vida como este milagre de começar o novo, tomar a iniciativa de romper com os discursos e práticas hegemônicas que incidem sobre nosso cotidiano, tornando-o monótono, repetitivo, sem perspectiva, cinzento, sem vida.

A dimensão política, que abordo neste capítulo, é da ordem desse milagre. Sintetizo a trajetória de protagonistas que tomaram a iniciativa de correr os riscos de construir o novo, a Reforma Psiquiátrica, a qual tem sua origem como movimento social no final dos anos 70, organiza-se e fortalecese nos anos 80, transformando-se em política pública de saúde, nos anos 90. Ao final, discuto as perspectivas e os desafios que se colocam no início deste milênio.

\section{REFORMA SANITÁRIA E REFORMA PSIQUIÁTRICA: MOVIMENTOS SOCIAIS}

Muitos dos principais movimentos sociais da segunda metade dos anos 70 nasceram nas periferias das grandes cidades e das necessidades cotidianas de sobrevivência: transporte, moradia, saneamento básico, saúde. São temas que possibilitaram a criação de uma identificação e o reconhecimento de interesses coletivos comuns. $\mathrm{Na}$ conversa com os vizinhos, nas discussões no 
salão paroquial da igreja, em encontros espontâneos nos lugares públicos, foi sendo organizado um movimento pautado em reivindicações vinculadas às condições de vida, especialmente da vida urbana. Para Jacobi (1989), tais condiçôes do cotidiano dos bairros e a organização coletiva possibilitaram o surgimento, na cena política, de novos sujeitos históricos, os quais foram se afirmando como essenciais interlocutores no processo de reconstrução da cidadania.

Surpreendendo a todos, pois até então as análises tendiam a interpretar a fábrica e o partido político como os lugares exclusivos e privilegiados das manifestações da classe operária, tais movimentos, pontuais em suas reivindicaçôes, surgiram, para Telles (1987), em um momento histórico marcado pela opressão, em que os canais de manifestações estavam emudecidos ou eliminados pelo regime autoritário. Apontaram para um sentido e um alcance que ultrapassou o imediato e o local, para mobilizar e articular, como experiência compartilhada, as várias opressões vividas em locais diferenciados. Ou seja, em tempos autoritários, as condições cotidianas de vida apareceram como campo de luta que permitiu a conquista de espaços políticos para a manifestação, articulação, reivindicação e exigências de direitos frente ao Estado, solidificando, na sociedade civil, a noção de participação e ação coletivas, acelerando a transição democrática.

Sader destaca a emergência de um novo sujeito social e histórico, naqueles movimentos sociais, onde havia

a promessa de uma radical renovação da vida política. Apontam no sentido de uma política constituída a partir das questōes da vida cotidiana. Apontam para uma concepção da política, a partir da intervenção direta dos interessados. Colocam a reivindicação da democracia referida às regras da vida social, em que a população trabalhadora está diretamente implicada: nas fábricas, nos sindicatos, nos serviços públicos e nas administrações nos bairros. Eles mostram que há recantos da realidade não recobertos pelos discursos instituídos e não iluminados nos cenários estabelecidos da vida pública. Constituem um espaço público além do sistema da representação política. Através de suas formas de organização e de luta, eles alargam as fronteiras da política. Neles aponta-se a autonomia dos sujeitos coletivos que buscam o controle de suas condiçōes de vida contra as instituições de poder estabelecidas. (Sader, 1995:313)

Nesse contexto, iniciou-se um movimento pela transformação das condições de saúde da população, o movimento da Reforma Sanitária. Em uma 
apresentação realizada em 2002, no evento comemorativo ao $20^{\circ}$ aniversário do curso de especialização em Saúde Mental da Ensp/Fiocruz, Sergio Arouca, um dos principais militantes e ideólogos do Sistema Único de Saúde (SUS), ao falar sobre as origens da Reforma Sanitária, ressaltou que ela nasceu não apenas no campo específico das reformas da saúde, mas da luta contra a ditadura. Aludiu a uma questão decisiva que se colocava à época: como se podia exercer uma profissão, no horário comercial, e ser revolucionário e contestador, no tempo livre? Como integrar isso? Pensar o trabalho e a formação na saúde e enfrentar o pensamento autoritário: essa grande questão deu origem ao movimento de medicina social, de saúde coletiva dentro dos departamentos de medicina preventiva que começaram a produzir reflexões e a realizar denúncias das contradições entre ditadura, pensamento autoritário e saúde, no seu sentido mais amplo.

Arouca salientava, com seu grande e contagiante entusiasmo, a íntima relação entre ser profissional e ser militante político ou protagonista. Militância entendida como uma atividade ética, de entrega aos valores na luta pela emancipação de todos, pelos interesses daqueles cuja voz é silenciada, a dos mais humildes, a dos humilhados. Não era possível ser um agente transformador apenas no restrito campo de atuação profissional. Era necessário ampliar essa visão e ação. Era preciso pensar e atuar na sociedade, no tempo histórico em que se vivia. Também não era possível pensar no campo da saúde apenas como um campo determinado por fatores eminentemente biológicos. A saúde tem determinantes sociais, o que implica pensála como resultante da complexidade de fatores sociais, econômicos, culturais e políticos. Transformar a saúde é transformar a sociedade que a produz enquanto processo social.

Escorel (1998) detalha as origens e a articulação desse processo, descrevendo a participação de outras instituições e outros atores, que foram se agregando, se articulando, compondo um processo histórico, tais como o Centro Brasileiro de Estudos da Saúde (Cebes), a Associação Brasileira de Pós-Graduação em Saúde Coletiva (Abrasco), os movimentos de saúde ligados às Comunidades Eclesiais de Base (CEBs) da Igreja Católica e setores dos movimentos estudantil e dos médicos residentes.

A Reforma Sanitária se colocava, assim, fundamentalmente como um processo político, entendido como possibilidade emancipatória na construção da polis, da esfera pública, dos bens comuns. Era um processo que levava à produção intelectual crítica, práticas e açôes alternativas ao modelo 
hegemônico, militância cotidiana, ocupação de espaços institucionais, articulações com outros setores da sociedade, ocupação de espaços no interior do aparato estatal, avanços e recuos. Um processo político, colocando em cena e em pauta a relação entre Estado e sociedade civil. A Reforma Sanitária se constituiu tensionando criticamente os termos dessa relação.

Paim afirma que a Reforma Sanitária pode ser considerada como um conjunto de princípios e proposições apresentados no relatório final da $8^{\mathrm{a}}$ Conferência Nacional de Saúde e como projeto consubstanciado em um conjunto de políticas articuladas que requerem uma dada consciência sanitária, uma participação da cidadania e uma vinculação com as lutas políticas e sociais mais amplas. É ainda um processo, porque

a proposta não se conteve nos arquivos nem nas bibliotecas, mas transformou-se em bandeira de luta, articulou um conjunto de práticas, e teceu um projeto político-cultural consistente enquanto prática social, tornando-se História. Trata-se, conseqüentemente, de um conjunto complexo de práticas (inclusive práticas de saúde) que integram a prática social. (Paim, 1997: 20)

Teixeira e Mendonça (1995) referem-se a três direcionamentos básicos das estratégias de luta pela Reforma Sanitária: a politização da questão da saúde, visando a aprofundar e difundir uma nova consciência sanitária, a alteração da norma legal necessária à criação do sistema único universal de saúde e a mudança das práticas institucionais sob a orientação dos princípios democráticos.

No interior desse processo mais amplo, localizamos a saúde mental trilhando os mesmos caminhos. Nascida a partir da mobilização de trabalhadores de saúde, no cotidiano de suas práticas institucionais e nas universidades, a Reforma Psiquiátrica buscou politizar a questão da saúde mental, especialmente na luta contra as instituições psiquiátricas; produziu reflexões críticas que provocaram uma ruptura epistemológica; criou experiências e estratégias de cuidado contra-hegemônicas; conquistou mudanças em normas legais e buscou produzir efeitos no campo sociocultural.

Todo esse processo se articulou com outros movimentos sociais e com a luta pela redemocratização do país, levando seus protagonistas a desempenhar uma militância que transcendia a questão específica da saúde mental. Mais do que isso, criou um movimento social, o Movimento da Luta Antimanicomial, congregador não apenas de setores da saúde mental, como 
profissionais, associações de usuários e familiares, como também estudantes, artistas, jornalistas, intelectuais.

Como a Reforma Sanitária, a Reforma Psiquiátrica se configura não apenas como mudança de um subsetor, mas como um processo político de transformação social. O campo da saúde mental é um lugar de conflitos e disputas. Lugar do encontro do singular e do social, do eu e do outro. É, também, o lugar de confronto: das ideias de liberdade, autonomia e solidariedade contra o controle e a segregação, da inclusão e da exclusão, da afirmação da cidadania e de sua negação. Portanto, campo de lutas políticas e ideológicas que envolvem militância, protagonismos, negociações, articulaçôes, pactuações. Assim, a Reforma Psiquiátrica é um movimento político, impregnado ética e ideologicamente, e o processo de sua construção não pode ser desvinculado da luta pela transformação da sociedade.

\section{ORIGENS DA REFORMA PSIQUIÁTRICA}

Podemos considerar, sem exagero, o escritor Machado de Assis como o primeiro crítico da psiquiatria brasileira e do sistema asilar, ainda que ele tenha escrito o texto $O$ Alienista, cuja primeira publicação data de 1881 , antes que essa disciplina médica adentrasse ao Asilo de Alienados. Já no início do século XX, encontramos outro escritor, Lima Barreto, retratando de forma crítica e pungente a sua própria experiência de interno em Cemitério dos Vivos.

No começo do século XX, encontramos igualmente os trabalhos do dr. Ulisses Pernambucano, considerado um dos pioneiros da psiquiatria social brasileira. No hospital psiquiátrico de Juqueri, nos anos 20, o dr. Ozório César utilizava-se da expressão artística como instrumento terapêutico. Nessa mesma linha, nos anos 40, temos o importante trabalho da psiquiatra Nise da Silveira e o Museu de Imagens do Inconsciente e, nos anos 60 e 70, têm relevância as experiências de comunidades terapêuticas desenvolvidas em diversos estados, em especial São Paulo e Rio Grandes do Sul.

Houve ainda dezenas, provavelmente centenas de experiências pontuais, localizadas, muitas efêmeras, espalhadas pelo país, realizadas ao longo do século XX, que buscavam humanizar o atendimento ou se contrapunham ao modelo hegemônico e, se pouco ou quase nada conseguiram mudar, serviram para lançar sementes e produzir pequenos brotos. 
O modelo hegemônico se caracteriza por ser essencialmente hospitalocêntrico e excludente. Desde a inauguração do Hospício Pedro II, em 1852, no Rio de Janeiro, até a década de 1960, a assistência psiquiátrica brasileira se constituiu por sua oferta exclusiva e compulsória de internação em hospitais psiquiátricos públicos. Para Resende (1987), com o golpe militar de 1964, a psiquiatria adquiriu o status de prática assistencial de massa, com o início da mercantilização da loucura, por meio da celebração dos convênios com o Instituto Nacional de Previdência Social (INPS), criado em 1967. A psiquiatria começou a transformar-se em um lucrativo negócio e, para defendê-lo, formou-se um poderoso lobby que atuava, e ainda atua, impedindo qualquer tentativa de mudança.

Destaque-se que a transformação da saúde em produto de consumo, em mercadoria, não foi exclusividade da psiquiatria, mas parte de um projeto mais amplo de implantação de um modelo médico-previdenciário, que, por um lado, estendeu a assistência médica a amplos setores da classe trabalhadora, em substituição às caixas de aposentadoria e à assistência médica dos sindicatos, extintas pelo governo militar. Por outro, incentivou a prática privada na saúde financiada pelo erário, como analisado por Oliveira e Teixeira (1986) e Braga e Paula (1981).

$\mathrm{Na}$ assistência psiquiátrica, Luiz Cerqueira (1984) apresenta os seguintes dados: em 1941, havia 3.034 leitos privados, enquanto, em 1978, esse número era de 78.273. Um crescimento de quase vinte vezes, em menos de quarenta anos. Em contrapartida, o número de leitos oficiais permaneceu quase inalterado no mesmo período: 21.079, em 1941, e 22.603, em 1978. ${ }^{4}$ O tempo médio de permanência oscilava sempre acima dos noventa dias, indício de uma duração média de internação alta, favorecendo a institucionalização dos pacientes, isto é, a constituição de uma população cativa de "consumidores compulsórios" das internações psiquiátricas. Saliente-se que, nos anos 60, segundo Cerqueira (1984) e Resende (1987), houve uma modificação no perfil nosológico da clientela dos hospitais psiquiátricos, surgindo uma proporção expressiva de pacientes neuróticos e alcoolistas, patologias cuja necessidade de internação psiquiátrica é, no mínimo, questionável. Cerqueira sublinha:

4 Apenas a título de comparação, em 1992, segundo dados obtidos no site <www.datasus.gov.br>, havia 90.163 leitos psiquiátricos no Brasil, sendo 68.652 leitos privados (76\%) conveniados ao SUS e 21.511 públicos e universitários (24\%). 
A empresa de saúde sempre viu o lucro e só o lucro. Não nos iludamos, porque esse é o seu papel. Não pode ver a saúde sob outro prisma. Em psiquiatria já tem o monopólio da assistência curativa individual através do leito hospitalar exatamente por ser a opção mais rendosa. Para ampliar tal monopólio, usa de todos os meios historicamente empregados pelo capitalismo selvagem. (Cerqueira, 1984: 226)

Paradoxalmente, é nesse contexto que começaram a surgir diversos documentos oriundos de encontros nacionais e internacionais, os quais apontavam para uma necessária mudança no modelo da assistência em saúde e em saúde mental.

Cerqueira, em texto escrito no ano de 1973, destaca esta lista de documentos nacionais e internacionais: "documentos irreversíveis, firmados por nossas autoridades e consagradores de uma assistência psiquiátrica não tradicional" (Cerqueira, 1984: 242).

Muitos tratavam da reorientação da saúde para as Américas, como, por exemplo, a III Reunião de Ministros da Saúde, em Santiago no Chile, em 1972, promovida pela Organização Pan-Americana de Saúde (Opas) e pela Organização Mundial de Saúde (OMS). Costa-Rosa destaca a apresentação do ministro da Saúde brasileiro, presente ao evento, situando o teor das formulações pretendidas e suas metas no campo da saúde mental:

O sistema nacional permanece profundamente alicerçado na assistência hospitalar, oferecendo poucos e minguados recursos extra-hospitalares (...). Há necessidade de uma reformulação de fundo e forma (...). A atuação preventiva com base em práticas, atividades e com a participação da comunidade é fundamental para que na década de 70/80 possamos suplantar as práticas asilares ou custodiais ainda presentes. (Mario Machado de Lemos apud Costa-Rosa, 1987: 69)

Firmou-se, a partir daquela reunião de ministros, um acordo para a execução de um programa de saúde mental no Brasil, com validade até 1974 e que propunha ênfase na formulação de uma política nacional de saúde mental. O Plano Decenal de Saúde para as Américas, firmado ao final do encontro, estabelecia as seguintes recomendaçôes para a saúde mental:

- Prevenção primária, secundária e terciária em saúde mental;

- Criação de serviços para diminuir a tendência de aumento de alcoolismo e fármaco-dependência;

- Planejamento de leitos psiquiátricos para cada 1.000 habitantes; 
- Priorizar o atendimento ambulatorial e hospitalização breve, de preferência em hospitais gerais;

- Criação de Centros Comunitários de Saúde Mental em cidades com mais de 100.000 habitantes e estimular a participação da comunidade em torno deles

- Modernização da legislação psiquiátrica;

- Modernização dos tratamentos, utilizando especialmente técnicas grupais;

- Estimular o ensino de saúde mental em escolas de medicina e de outras escolas que formam profissionais de saúde. (apud Figueiredo, 1996: 203)

Em 1973, o Ministério da Previdência aprovou o Manual para Assistência Psiquiátrica, que serviu de base para a portaria n. 32 de 1974, do Ministério da Saúde. Ambos os documentos enfatizavam princípios que orientavam para a psiquiatria de comunidade, como, por exemplo, incrementar a criação de unidades de saúde mental nas cidades com mais de 100.000 habitantes; dar prioridade ao tratamento ambulatorial e prioridade para hospitalização curta, de preferência em hospitais gerais e estabelecer uma relação de um leito para 1.000 habitantes nas zonas urbanas e um leito para 2.000 habitantes nas zonas rurais; capacitação de recursos humanos; promoção de investigações epidemiológicas e atividades de pesquisa em geral. Tanto o manual quanto a portaria, segundo Cerqueira, foram sabotados desde o primeiro dia. Em suas palavras:

Ambos (...) continuam letra morta, só para não diminuir os lucros da empresa de saúde nem demonstrar a fragilidade do modelo médico tradicional exclusivo, defendido por outros tantos psiquiatras reacionários encarrapitados nas cátedras, nas cúpulas administrativas e nos ricos consultórios privados. Conseguem leis, financiamentos, privilégios. (Cerqueira, 1984: 225)

Esses documentos demonstravam algumas semelhanças com as propostas da Reforma Psiquiátrica: crítica ao modelo hospitalocêntrico, participação da comunidade nos serviços, revisão da legislação psiquiátrica, criação e diversificação de novos serviços, ampliação da rede extra-hospitalar. Porém, com uma importante diferença: eles integravam um esforço internacional de implantar uma medicina de caráter preventivo, que, na psiquiatria, irá se concretizar mais claramente com o projeto norte-americano da psiquiatria preventiva de Gerald Caplan (1980). Na Reforma Sanitária, a análise crítica da medicina preventiva (Arouca, 2003) avançou para uma discussão sobre a saúde coletiva, questionando e redefinindo as noções fundamentais, tais como 
o processo saúde-doença, história natural das doenças, causalidade, clínica médica, com consequências técnicas, assistenciais, políticas, ideológicas e culturais. E, no processo da Reforma Psiquiátrica, as críticas sobre as reformas da psiquiatria nos anos 60 (Rotelli, Leonardi \& Mauri, 2001) e sobre a psiquiatria preventiva (Lancetti, 1989; Birman \& Costa, 1994) caminharam, também, para um profundo questionamento dos conceitos fundantes da psiquiatria, de suas instituições, de sua função ideológica de controle, com profundas repercussões não apenas na prática, com a construção de novos serviços, mas fundamentalmente com a construção de um novo paradigma, de que tratarei no capítulo a seguir.

Embora se constitua no discurso e na prática hegemônicos, o modelo psiquiátrico de assistência sempre recebeu críticas. Desde seu princípio, com Machado de Assis, passando pelas denúncias que frequentemente apareciam (e ainda aparecem) na imprensa, por meio de experiências inovadoras que questionavam, desde o interior do asilo, sua lógica de exclusão e de aniquilamento da subjetividade e, finalmente, nos documentos de organismos nacionais e internacionais nos anos 60. Contudo, não será a partir dos planos oriundos desde o aparelho estatal que a Reforma Psiquiátrica irá dar os seus decisivos passos iniciais.

Se todas aquelas críticas não conseguiram produzir um efeito de transformação ou mudança da política da saúde mental, deixaram sementes que serão regadas e fertilizadas por debates e discussóes realizados, principalmente, nas universidades que recebiam e repercutiam os ecos das notícias sobre, especialmente, dois grandes movimentos de ruptura com a psiquiatria: antipsiquiatria, de Laing e Cooper, e psiquiatria democrática italiana, de Franco Basaglia. ${ }^{5}$ Foi no final dos anos 70 que vários congressos e encontros possibilitaram a vinda ao Brasil desses importantes nomes, além de outros, como Michel Foucault, Robert Castel, Felix Guattari, Erwin Goffman.

Embora a presença de todos tenha sido de extrema importância, em distintas dimensões, Basaglia foi quem mais contagiou, produzindo um efeito de vontade e potência. A frase "contra o pessimismo da razão, o oti-

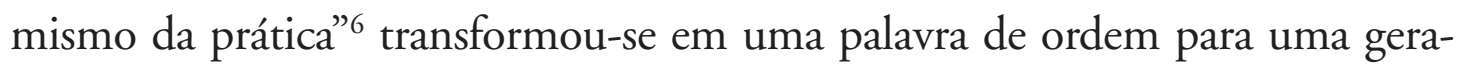
ção de profissionais, que ingressou nas instituições psiquiátricas, começou a

\footnotetext{
5 Fleming (1976) descreve esses movimentos, e Amarante (1998) retoma os paradigmas e sua articulação com o movimento da Reforma Psiquiátrica.

6 É o subtítulo da coletânea de suas conferências no Brasil (Basaglia, 1979).
} 
questioná-las e a buscar novas soluções concretas, fortalecendo a necessidade de politizar o discurso e a prática dos trabalhadores de saúde mental.

Foi a partir das reflexões e provocações produzidas por esses autores/ atores, especialmente por Basaglia, e de um clima de perseguição e repressão a manifestações de oposição ao regime, que a Reforma Psiquiátrica nasceu e se fortaleceu por meio, sobretudo, da mobilização dos trabalhadores que, ao recusarem o papel de funcionários do consenso (Basaglia \& Basaglia, 1977), tornaram visíveis os dispositivos de segregação e violência das instituições psiquiátricas.

Amarante (1998) aponta a greve dos médicos da Divisão Nacional de Saúde Mental (Dinsam), de 1978, como o evento que deu origem ao Movimento dos Trabalhadores de Saúde Mental, o primeiro gesto da Reforma Psiquiátrica. Naquele ano, médicos denunciaram as precárias condições às quais eram submetidos os pacientes nos hospitais psiquiátricos da Dinsam, órgão ligado ao Ministério da Saúde. Em abril, profissionais das quatro unidades do Rio de Janeiro deflagraram a primeira greve no setor público, após o regime militar, que logo recebeu o apoio de várias entidades. Vale lembrar que a primeira grande greve de metalúrgicos, liderada por Luiz Inácio Lula da Silva, foi realizada no $\mathrm{ABC}$ paulista, no mesmo ano.

Outro evento importante a destacar, ainda em 1978, foi o V Congresso Brasileiro de Psiquiatria, realizado em Camboriú (SC), conhecido como o Congresso da Abertura, em que,

pela primeira vez, os movimentos de saúde mental participam de um encontro dos setores considerados conservadores, organizados em torno da Associação Brasileira de Psiquiatria, estabelecendo uma 'frente ampla' a favor das mudanças, dando ao congresso um caráter de discussão e organização político-ideológica, não apenas das questôes relativas à política de saúde mental, mas voltadas ainda para a crítica ao regime político nacional. (Amarante, 1998: 53-54)

Ressalte-se que uma das moções aprovadas, ao final do congresso, foi pela "anistia, ampla geral e irrestrita". O congresso de Camboriú cumpriu função semelhante à do Movimento Democrático Brasileiro (MDB), ${ }^{7}$ no plano da política. Apesar de conservadora, a Associação Brasileira de Psiquiatria (ABP) acolheu e abriu espaço para o movimento da Reforma Psiquiátrica.

7 Um dos dois partidos permitidos pela ditadura militar, que representava a oposição. O outro partido era a Aliança Renovadora Nacional (Arena). 
E, assim como estes, em muitos outros eventos, congressos, encontros, ${ }^{8}$ enfim, onde houvesse a possibilidade de expressão para um público ainda que pequeno, havia um protesto, uma denúncia, uma moção de apoio. A negação do papel de carcereiros da loucura, de guardiôes da Razão e da Moral, implicava não apenas sua explicitação pública, mas a denúncia das condiçôes sociais, políticas, econômicas que determinavam e sustentavam aquele lugar.

Animado por uma nova geração de trabalhadores de saúde mental, a Reforma Psiquiátrica foi sendo construída por estes atores que vivenciavam o cotidiano de violência das instituições, sentiam a angústia das contradições que a prática impunha, mas que, inspirados pelo clima político-cultural, apostavam e acreditavam na possibilidade de transformação. Foram os atores envolvidos nesse processo que continuaram, nos anos 80 , ampliando a sua influência, ocupando espaços na administração pública e, principalmente, inventando novas instituições.

\section{ANOS 80: A REFORMA PSIQUIÁTRICA EM UM TEMPO QUE NÃO PARA}

Os últimos anos de governo militar foram vividos em uma conjuntura financeira internacional desfavorável, caracterizada pela recessão mundial, alta taxa de juros e a interrupção de créditos internacionais, colocando a economia brasileira, devedora e tomadora de empréstimos, em mais uma grande e grave crise. Internamente, houve acentuada queda do Produto Interno Bruto (PIB), elevado aumento dos juros internos, aumento da dívida externa e aceleração do processo inflacionário. Esse quadro, associado ao modelo concentrador de renda e a um grande arrocho salarial, gerou o fenômeno de 'estagflação', inflação sem crescimento econômico, que permeou a vida econômica brasileira ao longo dos anos 80 , os quais foram nomeados, por grande parte dos economistas brasileiros, como "a década perdida".

Paradoxalmente, foi nessa conjuntura desfavorável que a Reforma Sanitária e a Reforma Psiquiátrica começam a se apresentar, no cenário nacional,

8 Outros eventos importantes do período: I Congresso Brasileiro de Psicanálise de Grupos e Instituições, no Rio de Janeiro (1978); III Congresso Mineiro de Psiquiatria (1979); I Congresso Nacional dos Trabalhadores de Saúde Mental, em São Paulo (1979); I Encontro Regional de Trabalhadores em Saúde Mental, no Rio de Janeiro (1980); o Encontro Nacional dos Trabalhadores em Saúde Mental, paralelo ao VI Congresso Brasileiro de Psiquiatria, em Salvador/BA (1980). 
como um processo não apenas de transformação da assistência e de construção de uma nova agenda para a saúde pública, mas como um projeto de redemocratização. Noronha e Levcovitz enfatizam que o agravamento dos problemas econômicos enfrentado pelo país favoreceu o processo da Reforma Sanitária. Destacam a crise financeira da previdência, caracterizada por um forte déficit operacional que atinge seu ápice em 1981, decorrente da adoção de políticas econômicas recessivas. Ao mesmo tempo, intensificaram-se as críticas ao modelo de saúde, por parte dos movimentos populares emergentes e uma marcante produção científica "na crítica do modelo vigente, nas denúncias sobre as condiçôes de saúde da população e na proposição de uma nova política de saúde efetivamente democrática” (Noronha \& Levcovitz, 1997: 80). Institui-se, a partir desse quadro, uma agenda reformista do setor saúde, formulada e consolidada ao longo dos anos 70, sob a liderança das forças políticas democráticas, tendo como componentes essenciais a descentralização, a universalização e a unificação do sistema de saúde.

Um ator importante desse processo foi o Cebes, que, em outubro de 1979, apresentou o documento "A Questão Democrática na Área da Saúde", no 10 Simpósio sobre Política Nacional de Saúde na Câmara dos Deputados. No documento alinhavavam-se as diretrizes fundamentais que apontavam para "uma saúde autenticamente democrática": a saúde como direito; criação de um sistema único de saúde com a responsabilidade do Estado e a descentralização. Tratava-se de um documento histórico que se transformou na "plataforma programática do movimento sanitário, alcançando a adesão de parlamentares e sindicalistas, dando início a uma trajetória que culminaria com a inscrição destas propostas na Constituição federal de 1988" (Fleury, 1997: 28).

Para enfrentar a grave crise financeira, o governo militar buscou formular alternativas, como o Plano Prev-Saúde, que incorporou teses e propostas do Movimento Sanitário, tais como descentralização, hierarquização, regionalização e ênfase aos serviços básicos de saúde. ${ }^{9}$ Após suscitar debates e polêmicas, acabou por não ser implementado. Todavia, houve a incorporação de alguns atores do Movimento Sanitário na burocracia estatal, na tentativa de se buscar soluções para crise.

9 Teses que já haviam sido apresentadas no relatório final da conferência realizada pela OMS, na cidade de Alma-Ata, Cazaquistão, em 1978, da qual o Brasil foi signatário. Na ocasião, essas teses foram estabelecidas como características fundamentais da assistência pública à saúde. Propunham, também, o lema "Saúde para todos no ano 2000". 
Amarante (1998) relata que, no final de 1981, a Presidência da República criou o Conselho Nacional de Administração da Saúde Previdenciária (Conasp), um foro que contou com a participação, não paritária, de representantes governamentais, patronais, universitários da área médica e dos trabalhadores. Em agosto de 1982, o trabalho do Conasp se consubstanciou no Plano de Reorientação da Assistência Médica da Previdência, que propunha oficialmente modificações, as quais objetivavam a racionalização do sistema, a melhoria da qualidade dos serviços e a reversão do modelo assistencial privatizante, com a descentralização e a utilização prioritária dos serviços públicos federais, estaduais e municipais, na cobertura assistencial da população.

Como parte do Conasp, criou-se o projeto de Ações Integradas de Saúde (AIS). Constituiu-se em um importante instrumento de descentralização e de articulação institucional, possibilitando o repasse de recursos financeiros da União para os estados e prefeituras, utilizados de modo especial no reaparelhamento e reformas das unidades públicas, na contratação de pessoal para ampliação da rede de assistência e na implantação e ampliação de diversos programas de saúde (Noronha \& Levcovitz, 1997). A concretização das AIS, por meio dos convênios, ocorreu no momento posterior à eleição para governador, no ano de 1982, que marcou a vitória de vários partidos de oposição. Diversas experiências, principalmente a partir da política de saúde da Nova República, e a criação do Sistema Único Descentralizado de Saúde (Suds) serviram como laboratório de elaboração do projeto SUS.

Em alguns estados, como em São Paulo, o Suds já apresentava os princípios e diretrizes do SUS: universalidade; equidade; descentralização, regionalização e integração dos serviços de saúde; atenção integral; prioridade às ações básicas de saúde e à participação popular. Era o ideário da Reforma Sanitária se concretizando na capilaridade e no cotidiano dos serviços de saúde, na ampliação da rede, permitindo o acesso da população aos serviços básicos de saúde, a mudança nas relações entre as diferentes instâncias (municipal, estadual e federal), com uma maior implicação do nível municipal nas ações de saúde.

Em 1986, após uma intensa mobilização de diferentes atores e segmentos sociais, profissionais, quadros técnicos e - uma novidade - representantes de usuários, realizou-se a histórica $8^{\text {a }}$ Conferência Nacional de Saúde (CNS), ${ }^{10}$

${ }^{10}$ No total, participaram mais de cinco mil pessoas, sendo mil delegados. Significativamente, um único setor recusou-se a participar daquela conferência: os prestadores privados de saúde. 
que, em seu relatório final, expunha os princípios e diretrizes do SUS. Gerschman (2004) detalha o desdobramento dessa conferência, com a organização da Comissão Nacional de Reforma Sanitária (CNRS), de composição paritária governo/sociedade civil, e da Plenária Nacional de Entidades da Saúde, constituída pelas forças organizadas da sociedade civil.

Escorel afirma que a CNRS realizou um trabalho eminentemente técnico, com poucas repercussões políticas, enquanto a Plenária, visando à aprovação das propostas da $8^{\text {a }} \mathrm{CNS}$, fez-se representar intensamente na Constituinte e "obteve vitórias que culminaram na aprovação de um capítulo sobre saúde inédito na história constitucional, refletindo o pensamento e a luta histórica do movimento sanitário" (Escorel, 1998: 187).

Após essa vitória, a mobilização continuou para a consolidação do SUS com a criação, em 1987, do Suds e da Lei Orgânica da Saúde, concretizada em 1990.

Não é possível pensar a estratégia implementada pela Reforma Psiquiátrica desarticulada deste movimento da Reforma Sanitária. Assim, retornando à saúde mental, as AIS possibilitaram, em alguns estados, o princípio de uma reorganização da assistência.

No estado de São Paulo, isso ocorreu, principalmente, através do reaparelhamento dos hospitais psiquiátricos próprios, da contratação de profissionais e da ampliação da rede extra-hospitalar. Tal ampliação trouxe, para o campo da saúde mental, uma geração de jovens profissionais, ainda não contaminados pela inércia burocrática das instituiçōes públicas. Eles assumiram, com entusiasmo e de forma crítica, a tarefa de implantar as novas propostas e, fundamentalmente, trabalhar acreditando em mudanças. Em 1989, organizou-se, na cidade de São Paulo, a Plenária de Trabalhadores de Saúde Mental, um agente social coletivo que congregava diversas entidades ${ }^{11}$ e que atuou

${ }^{11}$ As seguintes entidades faziam parte da comissão organizadora: Associação dos Servidores da Secretaria de Saúde (Asses); Sindicato dos Assistentes Sociais de São Paulo; Sindicato dos Médicos de São Paulo; Sindicato dos Enfermeiros de São Paulo; Centro de Estudos do Hospital Pinel; Instituto Sedes Sapientiae; Grupo de Fonoaudiólogos de São Paulo; Sociedade de Psicodrama de São Paulo; Central Única dos Trabalhadores (CUT); Associação Paulista de Fonoaudiologia; Conselho Regional de Psicologia de São Paulo; Hospital das Clínicas da Faculdade de Medicina da Universidade de São Paulo (FMUSP); Grupo de Saúde Mental do Partido dos Trabalhadores (PT); Conselho Regional de Assistentes Sociais de São Paulo; Núcleo de Trabalho e Estudos de Psiquiatria Institucional; Centro Comunitário de Saúde Mental de Parelheiros; Trabalhadores de Saúde Mental de Osasco; Instituto de Psicologia da Pontifícia Universidade Católica (PUC); Grupo de Supervisores dos Ambulatórios de Saúde Mental; Sindicato dos Psicólogos de São Paulo. 
como um saudável e severo crítico das contradições da Coordenadoria de Saúde Mental de São Paulo. A plenária foi um lugar de encontro para a discussão e reflexão de muitas questões que emergiam de distintas dimensões da prática dos trabalhadores: dificuldades na implantação de serviços em áreas em que não havia nenhuma forma de atenção; inquietações teóricas e técnicas para atender às diferentes demandas dos usuários; lentidão nas respostas institucionais causadas pela inércia da burocracia estatal; críticas ao modelo psiquiátrico-preventivo da política de saúde mental; reivindicação da participação dos trabalhadores no processo de discussão das diretrizes dessa política. São questôes que se articulavam em torno de um importante eixo: a necessidade de mudar, de transformar a assistência psiquiátrica, tendo como perspectiva a transformação da saúde no contexto da transformação da sociedade.

A plenária organizou, no ano de 1986, o II Congresso de Trabalhadores de Saúde Mental do Estado de São Paulo, ${ }^{12}$ o qual surgiu como resposta ao realizado no ano anterior, organizado pela Coordenadoria de Saúde Mental (CSM), sem a participação dos trabalhadores de saúde mental em sua organização. Assim, buscava-se marcar uma diferença entre algumas das lideranças da Reforma Psiquiátrica, comprometidas com o aparato estatal, e o conjunto dos trabalhadores que desejavam imprimir uma dinâmica mais democrática e com maior participação na formulação da política de saúde mental.

Em março de 1987, foi inaugurado, em São Paulo, o Centro de Atenção Psicossocial (Caps) Professor Luiz da Rocha Cerqueira. Organizado, basicamente, a partir de um grupo de técnicos que atuavam na Divisão de Ambulatórios da CSM, ${ }^{13}$ ao longo dos anos, o centro incorporou diversos profissionais, oriundos de importantes experiências de transformação institucional que participavam da Plenária de Trabalhadores de Saúde Mental. O Caps acolheu, na composição de sua equipe, profissionais de diferentes formações teóricas e de atuação. Do confronto entre a diversidade de ideias e do encontro com a prática com os usuários foi-se construindo uma das mais importantes experiências institucionais daqueles anos. "O surgimento do Caps (...) passou a exercer forte influência na criação ou transformação de muitos serviços por todo o país" (Amarante, 1998: 82).

${ }^{12} \mathrm{O}$ congresso teve os seguintes temas-eixo: Saúde Mental e Trabalho; Saúde Mental e Movimentos Sociais; Saúde Mental e Constituinte.

${ }^{13}$ Instância técnica e administrativa responsável pela assistência psiquiátrica extra-hospitalar. Do grupo que elaborou o projeto do Caps, faziam parte a diretora daquela divisão, dra. Ana Pitta, e diversos técnicos responsáveis pela supervisão das unidades da CSM. 
Em junho de 1987, como desdobramento da histórica $8^{a}$ CNS de 1986, realizou-se, na cidade do Rio de Janeiro, a I Conferência Nacional de Saúde Mental (I CNSM), tendo como temas básicos: Economia, Sociedade e Estado: impactos sobre a saúde e doença mental; Reforma Sanitária e Reorganização da Assistência à Saúde Mental; Cidadania e Doença Mental: direitos, deveres e legislação do doente mental.

A conferência foi realizada em um clima de intensas polêmicas e discussões, e o relatório final demonstra a força de articulação da Reforma Psiquiátrica, fazendo prevalecer suas teses em praticamente todos os itens dos temas da conferência. No tema I - Economia, Sociedade e Estado -, denunciava-se o modelo econômico altamente concentrador brasileiro, apontando para a necessidade de se ampliar o conceito de saúde, considerando em seus determinantes as condiçóes materiais de vida. No tema II - Reforma Sanitária e Reorganização da Assistência -, o relatório reafirmava as teses do Movimento Sanitário, introduzindo a especificidade da saúde mental no contexto de suas diretrizes e princípios. No plano assistencial, reiterava a reversão da tendência hospitalocêntrica, com prioridade para o sistema extra-hospitalar, propondo o fim do credenciamento de novos leitos e a redução progressiva dos leitos psiquiátricos existentes. Por fim, no tema III - Cidadania e Doença Mental -, o relatório reafirmava, também, teses do Movimento Sanitário, sugerindo inclusões no texto constitucional, no que se referia ao direito à saúde e propondo reformulações da legislação ordinária que tratava especificamente da saúde mental, ou seja: código civil, código penal e legislação sanitária.

O texto final refletia o momento de intensos debates que vivíamos. É um relatório que colocava claramente a Reforma Psiquiátrica em um lugar marcado ideologicamente, assumindo a luta de classes como tensão social mais importante e afirmando, como urgente,

o reconhecimento da função de dominação dos trabalhadores de saúde mental e a sua revisão crítica, redefinindo o seu papel, reorientando a sua prática e configurando a sua identidade ao lado das classes trabalhadoras (...) É mister (...) resgatar para saúde sua concepção revolucionária, baseada na luta pela igualdade de direitos e no exercício real da participação popular, combatendo a psiquiatrização do social, a miséria social e institucional. (Brasil, 1988: 15)

De maneira geral, pode-se afirmar que aquela conferência apresentou uma ênfase nas proposições políticas e ideológicas. O relatório final alinha- 
vou argumentos que produziram as bases para as propostas e experiências práticas que viriam, na sequência, exercitar outras lógicas contrárias à asilar. Deve registrar-se, ainda, que a proposição antimanicomial, que vai atravessar os passos de boa parte das práticas da Reforma Psiquiátrica, até os dias de hoje, já se mostrava ali bem clara e plenamente afirmada.

Ao expor argumentos e proposições que articulavam o processo de transformação de um setor específico da saúde, a saúde mental, em uma luta que transcendia essa especificidade e a aproximava da luta pela transformação da sociedade, a Reforma Psiquiátrica se posicionava em uma estreita vinculação com a Reforma Sanitária. Ambas assumiam o pressuposto da saúde como uma questão revolucionária, tal como analisado por Escorel (1995), para quem a luta pela transformação da situação de saúde da população brasileira é parte privilegiada da luta pela transformação da sociedade, pois a arena da saúde é um campo de múltiplas interseçôes e relações com as demais esferas do desenvolvimento das sociedades. A saúde possui um valor universal e, por ser considerada como parte integrante das condições mínimas de sobrevivência, é componente fundamental da democracia e da cidadania. Assim como os outros direitos sociais, a saúde é um elemento potencialmente revolucionário, uma vez que se constitui em um campo privilegiado de luta de classes, em que se podem dar a formação e a transformação da consciência (luta ideológica), lugar onde se chocam as concepções de vida das diferentes classes sociais.

Mantendo as críticas ao asilo e à violência institucional, no ambiente da contestação ao regime militar, e fortalecendo o processo de redemocratização, a Reforma Psiquiátrica buscou ampliar as discussões técnicas para uma perspectiva política e social, expressa no relatório da I CNSM, o primeiro documento brasileiro oficial a colocar a questão da saúde mental nessa perspectiva da luta entre os interesses de classes.

Igualmente, a exemplo da Reforma Sanitária, a Reforma Psiquiátrica conquistou espaços dentro do aparelho estatal, no sentido de introduzir mudanças no sistema de saúde. Amarante (1998) observa que, a partir de 1985, uma significativa parcela dos postos de chefia de programas estaduais e municipais de saúde mental e, do mesmo modo, a direção de importantes unidades hospitalares públicas, sobretudo na região Sudeste do país, estavam sob a condução de fundadores e ativistas do Movimento dos Trabalhadores de Saúde Mental. Como exemplo, podemos citar os encontros de 
coordenadores de Saúde Mental da região Sudeste, realizados em 1985, na cidade de Vitória (ES), e em 1987, na cidade de Barbacena (MG), nos quais era possível encontrar vários militantes na posição de gestores. Dessa forma, ocupando praticamente todos os espaços,

encarregaram-se de elaborar novas propostas, produzir e reproduzir novas idéias, formar novos militantes. Operaram uma substituição de uma prática psiquiátrica conservadora ou voltada para interesses privados, por uma ação política de transformação da psiquiatria como prática social. (Amarante, 1998: 69)

A Reforma Psiquiátrica principiou, assim, seu processo de institucionalização, intensificando-se nos anos 90 e confundindo-se com o Estado. Tal processo já preocupava alguns atores que, nos intervalos e bastidores da I CNSM, articularam a realização, em dezembro de 1987, do II Congresso Nacional de Trabalhadores em Saúde Mental, na cidade de Bauru (SP). A escolha da cidade paulista deveu-se ao fato de ela estar sob uma administração progressista (à época), o que favoreceu o apoio para a organização e para a realização do evento. Além disso, havia várias lideranças expressivas da Reforma Sanitária, como David Capistrano, secretário municipal de Saúde, e da Reforma Psiquiátrica, como Roberto Tykanori, que lá tinham implantado o primeiro Núcleo de Atenção Psicossocial (Naps).

Dentre os eixos de discussão do congresso, ${ }^{14}$ um apontava para uma nova estratégia a ser desenvolvida pelo movimento: o lema "Por uma sociedade sem manicômios". Adotado nacionalmente, a partir desse evento, o lema colocava em destaque a questão da loucura no âmbito sociocultural. Tratava-se de: produzir uma utopia norteadora das propostas assistenciais; resgatar a discussão sobre segregação e a violência institucional; repensar as práticas e inventar possibilidades para ampliar o campo de atuação. Tratava-se, também, de uma profunda e radical ruptura com o modelo hegemônico médico-centrado de produção de um saber técnico, de uma Razão instrumental, sobre a loucura.

O congresso contou com a presença de lideranças municipais, técnicos, usuários, familiares, estudantes e muitas outras pessoas, em um clima

${ }^{14}$ Os outros eixos eram: Organização dos Trabalhadores de Saúde Mental: a relação com o Estado e com a condição de trabalhadores da rede pública e Análise e Reflexão das nossas Práticas Concretas: uma instância crítica da discussão e avaliação (a quem servimos e de que maneiras). 
de muita vitalidade e participação. Dentre as deliberações, uma estabeleceu o dia 18 de maio como o Dia Nacional de Luta Antimanicomial. ${ }^{15}$ No encerramento, realizou-se uma passeata pelas ruas de Bauru, com mais de trezentas pessoas pedindo a extinção dos manicômios. O Manifesto de Bauru, aprovado na plenária e distribuído no dia da passeata, marcou o nascimento de um novo movimento: o Movimento Nacional da Luta Antimanicomial, cujas ideias podem ser assim expressas:

Nossa atitude marca uma ruptura. Ao recusarmos o papel de agentes da exclusão e da violência institucionalizadas, que desrespeita os mínimos direitos da pessoa humana, inauguramos um novo compromisso. Temos claro que não basta racionalizar e modernizar os serviços nos quais trabalhamos. O Estado que gerencia tais serviços é o mesmo que impõe e sustenta os mecanismos de exploração e de produção social da loucura e da violência. O compromisso estabelecido pela luta antimanicomial impóe uma aliança com o movimento popular e a classe trabalhadora organizada. O Manicômio é a expressão de uma estrutura, presente nos diversos mecanismos de opressão deste tipo de sociedade. A opressão nas fábricas, nas instituições de menores, nos cárceres, a discriminação contra os negros, homossexuais, índios, mulheres. Lutar pelos direitos de cidadania dos doentes mentais significa incorporar-se à luta de todos os trabalhadores por seus direitos mínimos, à saúde, justiça e melhores condiçōes de vida (Conselho Regional de Psicologia, 1997: 93)

Desde o congresso, esse nascente movimento, talvez a face mais politicamente ativa da Reforma Psiquiátrica, organizou-se em vários estados e caminhou para uma articulação nacional. O Movimento da Luta Antimanicomial (MLA) buscou manter, ao longo dos anos, uma singular e importante peculiaridade: a de existir como um movimento, sem se tornar uma instituição: não há uma sede, fichas de inscrição ou rituais de filiação. Existe como uma utopia ativa, prenha de desejos e ideais de transformação, e como materialidade na prática cotidiana de profissionais, familiares, usuários e tantos outros que se identificam com seu ideário. É, fundamentalmente, um dispositivo social que congrega e articula pessoas, trabalhos, lugares.

Com a eleição para prefeitos, em 1989, a cidade de Santos, na gestão do Partido dos Trabalhadores (PT), produziu uma experiência singular que,

${ }^{15}$ Após algumas discussões, uma das primeiras datas sugeridas foi 13 de maio, data da aprovação da lei n. 180 da Itália e da libertação da escravatura. Mas a escolha acabou recaindo no dia 18 de maio, sem nenhum motivo mais relevante. Apesar disso, a escolha marca uma grande coincidência: 18 de maio é também o dia da inauguração do Hospital Psiquiátrico de Juqueri. 
de certa forma, abrangeu as duas características mais marcantes da Reforma Psiquiátrica ao longo da década de 1980: a ocupação dos espaços de decisão e de poder do aparelho estatal e, como decorrência, a possibilidade de produzir e sustentar politicamente um processo de transformação radical da assistência em saúde mental.

Em maio de 1989, a Casa de Saúde Anchieta, hospital psiquiátrico privado, sofreu uma intervenção da Secretaria Municipal de Saúde, em função das atrocidades, incluindo-se mortes, cometidas com os pacientes lá internados. Iniciou-se, a partir da "desmontagem do manicômio", um processo de transformação exemplar, com implantação de uma rede de atenção em saúde mental substitutiva. Para Fernanda Nicácio (1994: 24):

A transformação da Saúde Mental em Santos tem se configurado como processo social complexo ancorado na desconstrução do paradigma psiquiátrico; partindo da desmontagem manicômio, como síntese da "instituição a ser negada", projeta a construção da Saúde Mental como território de cidadania, emancipação e reprodução social. (grifo meu)

Esta foi, durante muitos anos, a experiência de maior repercussão, tanto nacional quanto internacionalmente. Pela primeira vez, tínhamos em um município a prática concreta de uma organização de serviços e ações de saúde mental efetivamente substitutiva à internação psiquiátrica. Construiuse uma rede territorial constituída por: 1) Naps, unidades de cuidado, regionalizados, funcionando 24 horas por dia e sete dias na semana e que respondiam à demanda de saúde mental em sua área de abrangência; 2) o Pronto-Socorro Psiquiátrico Municipal, o qual tinha como objetivo ser retaguarda do sistema na atenção à crise e urgência/emergência, em particular no período noturno; 3) a Unidade de Reabilitação Psicossocial, que coordenava e desenvolvia os empreendimentos de trabalho; 4) o Centro de Convivência Tam-Tam, iniciado a partir da Rádio Tam-Tam, que desenvolvia projetos culturais e atividades artesanais; 5) o Lar Abrigado República Manoel da Silva Neto, moradia e espaço de atenção para usuários gravemente institucionalizados, com debilidades clínicas e físicas importantes. Esta organização colocou em ação conceitos e dispositivos, hoje, consagrados que fazem (ou deveriam fazer) parte do cotidiano dos serviços de saúde, tais como: território, responsabilização, cooperativas de trabalho e residência terapêutica. 
Durante oito anos, de 1989 a 1994, Santos representou o que de mais emblemático e paradigmático se podia realizar, no sentido da transformação não apenas das ações de saúde mental, mas do sistema de saúde. Porém, as sucessivas derrotas eleitorais, nos anos seguintes, para partidos políticos de orientação conservadora, desarticularam essa experiência, retirando dela muito de sua vitalidade inovadora e de seu compromisso ético e político com a transformação social. Os valores que constituem a essência da Reforma Psiquiátrica não fazem parte, via de regra, nem do ideário, nem da prática política dos partidos conservadores, refratários às noções e valores de participação popular, controle social, autonomia dos indivíduos. Nesse sentido, uma experiência como a de Santos se nutre da militância aguerrida dos trabalhadores, que é absolutamente necessária, porém insuficiente para sustentar um projeto ambicioso como aquele, o qual requer uma implicação, uma articulação e uma sustentabilidade política. Não se tratou apenas da construção de uma rede de novos serviços, os Naps, mas da organização de um complexo sistema de saúde que implicou a tessitura de uma rede intersetorial, ativando e provocando outras secretarias e outras instituiçôes, em um projeto de transformação social.

A definição de 'conservador' apresenta, nesta passagem de um milênio a outro, grandes dificuldades que não cabe aprofundar neste trabalho. Bobbio, Matteucci e Pasquino (2000) afirmam que, para a ciência política, o conservadorismo designa ideias e atitudes que visam à manutenção do sistema político existente e dos seus modos de funcionamento, contrapondo-se às forças inovadoras. Sublinham que é essa tensão que o definirá sempre em relação ao 'progressismo', de modo que ambos os termos só podem ser entendidos em seu contexto histórico. Complementando, argumentam: "Com o advento da sociedade de massas no curso do século XX, os termos do problema se modificaram de tal modo que a antítese conservadorismoprogressismo (...), conquanto ainda presente na linguagem política, se poderia considerar em crise" (Bobbio, Matteucci \& Pasquino, 2000: 245-6).

Levando em conta esse alerta, tomo neste trabalho a ideia de um par antitético conservadorismo/progressismo como representantes políticos, de um lado, dos interesses da sociedade em manter a estrutura social; de outro, das forças sociais que lutam para a transformação da sociedade. Luz, ao analisar o processo histórico de descentralização nas políticas sociais do Brasil, apresenta a seguinte hipótese: 
a concentração política apenas exprime a enorme concentração sócio-econômica persistente na sociedade brasileira, manifestando a resistência de poderes particularistas regionais (avessos a mudanças no sentido universalista) profundamente arraigados no solo social. Esses poderes, geralmente de base local, corporativos e conservadores, estão dominantemente representados nos três poderes do Estado em seu nível central. E tendem a inviabilizar as tentativas de descentralização/desconcentração nas políticas públicas propostas em mais de uma conjuntura no desenvolvimento secular da República. (Luz, 2000: 301)

Nessa perspectiva, as experiências mais interessantes, inovadoras e avançadas que tivemos em gestôes municipais foram implantadas por lideranças políticas ligadas, geralmente, a partidos progressistas que se opuseram aos poderes conservadores locais. $\mathrm{O}$ que não significa dizer que os partidos com perfil progressista garantam por si sós propostas de avanço na perspectiva da implementação de políticas redistributivas ou da transformação social. Pelo contrário, por vezes, no poder, reproduzem os mesmos dispositivos e comportamentos conservadores. Afinal, a prática política é, parafraseando Nietzsche, um ato humano, demasiadamente humano.

Retornando ao ano de 1989, a Prefeitura de São Paulo também desenvolveu um processo de mudança na assistência em saúde mental da capital, mas de natureza distinta. $\mathrm{O}$ projeto baseou-se na constituição de uma rede de serviços e de estratégias, tais como centros de convivência, hospital-dia, emergências psiquiátricas, leitos psiquiátricos em hospital geral, em que cada equipamento visava a dar conta de um determinado nível de complexidade de atenção à saúde mental, em uma organização baseada no princípio da hierarquização dos serviços de saúde. A experiência dos centros de convivência ${ }^{16}$ foi inovadora, pois levava aos equipamentos públicos de lazer da cidade, principalmente aos parques municipais, a possibilidade da criação de um espaço de convivência com a diferença.

E, ainda em 1989, a Reforma Psiquiátrica, sob o impacto da intervenção do Hospital Anchieta em Santos e da exemplaridade do processo que lá se desenvolvia, conquistou uma importante vitória, ainda que parcial: a aprovação pela Câmara dos Deputados do projeto de lei n. 3.657, de autoria do deputado Paulo Delgado, cuja proposta defendia a extinção progressi-

\footnotetext{
${ }^{16}$ Espaços localizados em áreas de lazer, onde eram desenvolvidas atividades de diversos tipos: aulas de tai-chi-chuan, de canto, artesanato etc. Além dos pacientes das diferentes unidades, qualquer pessoa podia participar daquelas atividades.
} 
va dos hospitais psiquiátricos e sua substituição por outros recursos assistenciais. Este fato estimulou, nos anos seguintes, uma mobilização em estados e municípios, para a elaboração e promulgação de leis com conteúdo e direção do projeto do deputado Paulo Delgado.

No final dos anos 80, surgiu um novo ator na Reforma Psiquiátrica: as associações de usuários e familiares. Além da pioneira Sociedade de Serviços Gerais para a Integração (Sosintra) do Rio de Janeiro (criada em 1978) e do Grupo Loucos pela Vida de Juqueri, nasceram a Associação Franco Basaglia (São Paulo), a Associação Franco Rotelli (Santos), o SOS Saúde Mental, entre outras. A reforma deixou de ter a participação majoritária de trabalhadores da saúde e passou a contar com familiares, usuários e outras pessoas não ligadas diretamente ao campo da saúde mental. As associações atuaram na construção de novas possibilidades de atenção e cuidados e na luta pela transformação da assistência em saúde mental. Amarante (1998: 82) acrescenta:

Com o processo da reforma psiquiátrica saindo do âmbito exclusivo dos técnicos e das técnicas, e chegando até a sociedade civil, surgiram novas estratégias de ação cultural com a organização de festas e eventos sociais e políticos nas comunidades, na construção de possibilidades até então impossíveis.

Ao finalizar os anos 80, tínhamos um panorama muito distinto daquele encontrado no final dos anos 70. Era um país diferente, com a eleição direta para Presidência da República, com uma nova Constituição, com a perspectiva e a esperança da construção de uma nação mais soberana e democrática. No campo da saúde, a mobilização continuava em torno da institucionalização da Reforma Sanitária, especialmente na luta pela aprovação da Lei Orgânica da Saúde. No âmbito da saúde mental, a partir de uma situação em que havia apenas o hospital psiquiátrico, encontramos, no raiar dos anos 90, os seguintes fatos: a exemplaridade de algumas importantes experiências singulares e paradigmáticas, como a do Caps Luiz Cerqueira, a organização da saúde em Santos e os centros de convivência; um movimento organizado nacionalmente, representado pelo Movimento da Luta Antimanicomial; a ampliação da organização de associações de usuários e familiares; o início da mudança na legislação federal e a criação de leis em vários estados e municípios, e o começo da institucionalização da Reforma Psiquiátrica. 
Tínhamos, fundamentalmente, um amplo e complexo movimento social, com múltiplas faces. Para Cohn (2003: 11), os movimentos sociais se caracterizavam

\begin{abstract}
por se constituírem em "novos" sujeitos coletivos no cenário político em distintas e diferenciadas arenas e espaços que não aqueles tradicionalmente definidos pela concepção clássica da democracia. Por outro lado, constituem igualmente sintomas de conflitos presentes na própria sociedade na medida em que se caracterizam por um forte traço reivindicativo na luta por conquistas na efetivação de demandas sociais, vale dizer, dos direitos sociais.
\end{abstract}

A Reforma Psiquiátrica constituiu-se do mesmo processo de discussão, debates e ações políticas para a redemocratização do país, para a conquista de direitos sociais, para a mudança da relação entre Estado e sociedade civil. Surgiu como um 'novo' sujeito coletivo, implicando centenas de atores no processo de desconstrução crítica do manicômio, de rupturas conceituais e invenção de propostas assistenciais, de articulação e conquista de espaços para a sua concretização. Foi uma década de construção de um grande projeto político de transformação, que se consolidou como política oficial do Ministério da Saúde, ao longo dos anos 90.

\title{
OS ANOS 90: REMANDO CONTRA A CORRENTE DA INSTITUCIONALIZAÇÃO DA REFORMA
}

O tom dos anos 80 foi dado pelo processo político de redemocratização e pela construção de um novo pacto social consubstanciado na nova Constituição. Porém, os problemas econômicos do país agravaram-se. Com o processo democrático consolidado, o tom dos anos 90 seria dado por uma agenda política que colocou a estabilidade econômica como prioridade número zero, subordinando todos os outros aspectos da vida social ao cumprimento dessa meta.

No plano internacional, as décadas de 1980 e 1990 se caracterizam por uma onda conservadora de reformas no plano político, econômico e social, que fortaleceu o que se tem nomeado, não sem controvérsias, de pensamento neoliberal, produzindo impactos no papel do Estado como executor e responsável pelas políticas sociais. Essa proposta de uma nova engenharia do Estado, reduzindo drasticamente seu papel, implementada 
especialmente nos países europeus, teve consequências para os países da periferia.

No final dos anos 80, em função da crise da dívida externa dos chamados países emergentes (Rússia, países da América Latina e do sul da Ásia), um grupo de intelectuais elaborou uma série de formulações que foram sistematizadas por John Williamson, ${ }^{17}$ do Institute for International Economics, no texto "What Washington means by policy reform", publicado, em 1990, no livro Latin American Adjustment: how much has happened?. Essas formulações, que ficaram conhecidas como Consenso de Washington, foram adotadas e utilizadas como receituário aos países devedores pelo governo norte-americano e pelas organizações financeiras como o Fundo Monetário Internacional (FMI) e o Banco Mundial. Williamson concebe o Consenso como uma estratégia de reformas da economia, orientadas para o mercado, composta por dez pontos: disciplina fiscal, visando a eliminar o déficit público; mudança nas prioridades para despesas públicas, abolindo subsídios e investindo em áreas sociais, como saúde e educação; reforma tributária; liberalização do sistema financeiro, com taxas de juros determinadas pelo mercado; taxa de câmbio competitiva; liberalização comercial, com ênfase no comércio exterior; liberalização da entrada do investimento direto; privatização das empresas estatais; desregulamentação da economia; direitos da propriedade assegurados.

Esse modelo de reforma, por exigência das instituições financeiras internacionais, foi amplamente adotado, especialmente pelos países latinoamericanos. Podemos identificar, nesses dez pontos, a agenda de reformas que se implantou no Brasil, ao longo da década de 1990 e que, infelizmente, ainda continua, no raiar deste século XXI. Em 2003, Williamson e Kuczynski (2003) organizaram o livro After the Washington Consensus: restarting growth and reform in Latin America, no qual diversos autores buscam respostas às razões que levaram os países da América Latina a resultados tão decepcionantes do crescimento econômico, da estabilidade e dos índices sociais, após a adoção das medidas do Consenso. Tais autores apontam para o fato de as reformas propostas pela agenda do Consenso não terem sido implementadas na região de forma completa ou, quando implementadas, foram inconsistentes e ocorreram em uma ordem não satisfatória. Williamson

${ }^{17}$ Economista que conhece bem o Brasil. Já lecionou na PUC-RJ (1978 a 1981) e é casado com uma brasileira. 
(2003) propõe que o objetivo da política econômica não deve ser apenas a estabilidade dos preços, mas também a estabilidade da economia, o que significa: manter uma severa política fiscal (aumentar receita, gerar superávit e cortar gastos); implementar uma política cambial flexível para aumentar a competitividade internacional; aumentar a poupança interna; maior flexibilização da economia, especialmente em relação às leis trabalhistas; reformas institucionais (sistemas políticos, administrações públicas, sistemas judiciais, instituições financeiras, sistemas de educação, de saúde, segurança etc.). Como se pode ver, continuamos com a mesma agenda.

A adoção e a defesa desse modelo, especialmente a disciplina fiscal, para a estabilidade econômica do país, converteu-se em um grande obstáculo na implementação e na consolidação de políticas sociais abrangentes e redistributivas, como a proposta da Reforma Sanitária.

Foi, e ainda é, neste panorama desfavorável, que se consolidou o processo de organização e implantação do SUS, principal bandeira de luta do Movimento Sanitário, que, como já destacamos, tomou o campo do aparelho de Estado como palco privilegiado de luta.

No Brasil, os anos 90 começaram com a posse do presidente Fernando Collor de Mello, que logo apresentou os aspectos que marcariam a sua administração: início da implementação da política neoliberal, que teve como resultado o desmonte das políticas públicas, uma atuação de caráter autoritário e centralizador, bem como escândalos relacionados à corrupção, que levariam ao seu impeachment.

Tais aspectos retardaram o avanço da Reforma Sanitária, que havia obtido importantes conquistas nos anos anteriores. O autoritarismo e a falta de respeito às regras democráticas evidenciam, como aponta Gerschman, a íntima, profunda e necessária relação da Reforma Sanitária com a democracia. Prossegue Gerschman (2004: 180),

Entendemos que o avanço da implementação da Reforma poderia necessariamente requerer o afiançamento do processo político-democrático, considerando que ela previa um espaço considerável de participação social na gestão do sistema de saúde e, particularmente, no processo de descentralização do sistema, o qual constitui a coluna vertebral desse processo.

O centralismo autoritário do governo Collor valeu-se de todos os dispositivos disponíveis para emperrar e impedir o processo da Reforma Sanitária. 
Como exemplo, podemos citar a aprovação da Lei Orgânica da Saúde, obtida graças a uma intensa mobilização e articulação das forças políticas em favor da reforma, agrupadas na Plenária das Entidades de Saúde. Contudo, todos os artigos referentes à participação social foram vetados, obrigando a uma nova mobilização e à aprovação de uma outra lei (lei 8.142/ 1992), que dispõe sobre a realização das conferências e sobre os Conselhos de Saúde, tornando-os obrigatórios. A 9a CNS foi organizada e realizada após intensas pressões e já sob o quadro de crise institucional que levariam Collor ao impeachment, no ano de 1992. O lema não oficial daquela conferência, retirado de um documento preparatório foi: "A ousadia de fazer cumprir a lei".

Mesmo após o impeachment, a política econômica continuou a seguir o modelo de reforma neoliberal imposto pelos organismos internacionais. É nesse quadro economicamente desfavorável e de retrocesso, nos anos iniciais, que a Reforma Sanitária foi implementando um de seus mais importantes eixos do SUS: a descentralização.

Para Hortale, Pedroza e Rosa, a descentralização possui uma dimensão política e é uma condição necessária para melhorar o acesso, a adequação da resposta social, a participação, a qualidade, a sustentação e a equidade no campo da saúde. Consideram que

um sistema de saúde descentralizado, em uma dinâmica de transferência de recursos e autoridade às diferentes instâncias do sistema de saúde, causa um impacto positivo na gestão e nas diferentes modalidades de atenção e dá oportunidade para que os processos de reforma permitam a geração e desenho de novos modelos de atenção, papéis e funções, modalidades de capacitação, sistemas de remuneração e novas formas de participação das instituiçōes, sindicatos e setores acadêmicos. (Hortale, Pedroza \& Rosa, 2000: 232)

Já Levcovitz, Lima e Machado frisam que, apesar das diferenças nas análises, há um consenso sobre os avanços no âmbito da descentralização em saúde predominante no Brasil, caracterizando-a como sendo do tipo político-administrativo, envolvendo não apenas a transferência de serviços, mas também de responsabilidades, poder e recursos da esfera federal para a estadual e municipal. Ressaltam, porém, que a descentralização "não garante o caráter democrático do processo decisório e necessita ainda do fortalecimento das capacidades administrativas e institucionais do governo central na condução do processo" (Levcovitz, Lima \& Machado, 2001: 272). 
A consolidação do SUS, portanto, requer a existência de mecanismos de regulação que deem conta do dinamismo desse processo. Nesse sentido, as Normas Operacionais Básicas (Noas), que tratam dos aspectos de divisão de responsabilidades, relaçóes entre gestores e critérios de transferência de recursos federais para Estados e municípios, passaram a representar instrumentos fundamentais para a concretização da descentralização estabelecida pela Constituição e pela legislação do SUS.

Tal processo colocou em cena milhares de gestores municipais de saúde que passaram a se constituir, por vontade própria, ou compulsoriamente, por força da função que exerciam, em atores fundamentais no campo da saúde. O Conselho Nacional de Secretarias Municipais de Saúde (Conasems), o Conselho Nacional de Secretários de Saúde (Conass) e os Conselhos de Secretarias Municipais de Saúde (Cosems) passaram a desempenhar um importante papel, sobretudo a partir de 1994, ano em que foram constituídas as Comissóes Intergestores Bipartites, reunindo municípios e governos estaduais, e a Comissão Intergestores Tripartite, reunindo municípios, governos estaduais e governo federal. Essas comissões são órgãos colegiados deliberativos sobre as questôes referentes à implantação e implementação do SUS e fórum de discussão sobre os impasses entre as partes envolvidas no processo.

No âmbito dos municípios, a descentralização fortaleceu a constituição dos conselhos municipais de Saúde, órgãos colegiados, de composição paritária entre representantes do governo e da sociedade, com a função de controle e de deliberação sobre a implantação e implementação das ações de saúde do SUS. São mecanismos de participação e controle popular e buscam democratizar as relações entre Estado e sociedade.

Todavia, o que vamos encontrar caminhando ao lado do processo de descentralização é um tema central e recorrente: o financiamento e a falta de recursos para a saúde. A universalização da assistência, a reorganização do sistema para eliminar as barreiras do acesso e garantir a integralidade das ações de saúde, a mudança do modelo médico hegemônico pela implementação de estratégias como o Programa Saúde da Família (PSF) e o Programa de Agentes Comunitários (Pacs), a democratização dos mecanismos decisórios por meio do controle social exercido pela comunidade nos conselhos de Saúde, enfim, todos temas relevantes que compõem o mais essencial e valioso existente na Reforma Sanitária, ficaram subordinados ao tema do financiamento. 
A descentralização colocou o Ministério da Saúde e as secretarias municipais e estaduais de Saúde como os principais atores indutores do processo da reforma, deslocando os movimentos sociais para um papel secundário, quase de estorvo. A definição do arcabouço jurídico-legal e da engenharia institucional, associada à questão sempre problemática do financiamento, transformou esse complexo processo em uma questão administrativo-gerencial. A lógica do financiamento e da administração tomou o lugar das mudanças.

Arouca criticava a paralisia e o conformismo frente aos efeitos que a relevância da lógica do financiamento estava produzindo no SUS, declarando:

O momento que estamos vivendo revela a paralisia do pensamento crítico nacional. O movimento sindical está paralisado e a universidade não tem feito nenhum debate crítico mais avançado. Isso exige que retomemos a Reforma Sanitária, enxergando o SUS a partir dessa reforma, e não vendo o SUS pelo umbigo do SUS. O umbigo do SUS vai apenas tentar regular o que está aí. Outro dia, ouvi um médico dizer com maior orgulho que tinha triplicado o número de amputaçôes de diabéticos. Se o conceito é de produtividade e serviço, então ele amputa mais para ganhar mais. Para mim, isso é a falência. $\mathrm{O}$ conceito fundamental dessa última fase do SUS é o faturamento. Foi uma distorção na implantação do SUS. (Arouca, 2002: 21)

O processo de consolidação do Estado democrático, que restaurou os direitos inscritos na Constituição cidadã, como afirmava Ulysses Guimarães, não conseguiu incorporar uma parcela significativa da população, a qual continuou à margem do mundo dos direitos e do "mundo maravilhoso do capitalismo globalizado". A política econômica tem afrontado esse processo, ao propor, seguindo as orientaçôes do Consenso de Washington impostas pelos organismos internacionais, a desregulamentação e a redução das tarefas do Estado, implantando o chamado "Estado mínimo", entregando suas atribuições à lógica de uma onipresente figura denominada "mercado", que, em nossa dependente economia, têm-se revelado extremamente perversas, já que aumentam a acumulação de riquezas das elites, aprofundando a mais do que injusta distribuição de renda e agravando a crise social.

Segregação, violência e exclusão continuam, mais do que nunca, sendo pautas na agenda da discussão nacional. Desse modo, a defesa da noção de "saúde direito de todos e dever do Estado" cumpre um importante papel. Além de transformar a saúde em questão nacional, como afirma Escorel 
(1995), lança uma contraofensiva de caráter ideológico em defesa não só de um direito constitucional, mas de uma perspectiva de entendimento de uma sociedade que garanta efetivamente os direitos básicos de acesso à saúde, ao trabalho, à educação, à moradia.

$\mathrm{Na}$ Reforma Psiquiátrica, essa defesa se construiu na articulação dos novos serviços com outros segmentos dos movimentos sociais, tais como as associações de usuários e familiares, organizações não governamentais (ONGs), sindicatos etc. Essa estratégia estabeleceu uma diferença, especialmente nos anos 90, entre a Reforma Psiquiátrica e a Reforma Sanitária: por um lado, ocupou espaços no aparelho estatal e, por outro, manteve uma identidade de movimento social, por meio do Movimento da Luta Antimanicomial e das associações de usuários. Nutrindo-se das cotidianas questôes que surgiam no embate da construção da transformação da assistência, a Reforma Psiquiátrica se atualizava, também, com as questões sociais de seu tempo histórico.

A ocupação dos espaços no interior do aparelho estatal guiou-se pelas mesmas trilhas da Reforma Sanitária, com os mesmos riscos e problemas. No contexto da descentralização e da municipalização, a transferência de recursos financeiros da saúde mental era oriunda apenas da internação e das consultas ambulatoriais. Serviços altamente complexos e modelos de propostas assistenciais, como o Caps e os Naps, não existiam para o SUS. Em novembro de 1991, a Secretaria Nacional de Assistência à Saúde do Ministério da Saúde publicou a portaria n. 189/1991, que modificou a sistemática de remuneração das internações hospitalares, procurando reduzir o tempo de internação, ${ }^{18}$ e criou diversos procedimentos, buscando contemplar as diferentes experiências assistenciais que estavam sendo realizadas: Naps/ Caps, oficinas terapêuticas, visitas domiciliares, dentre outras. Logo, em janeiro de 1992, foi publicada a portaria n. 224, que estabeleceu diretrizes e normas para a assistência em saúde mental.

Essas portarias incentivaram a criação de diversas unidades assistenciais espalhadas pelo país, com o nome de Naps ou de Caps. Contudo, muitos municípios encontraram, nos procedimentos de saúde mental, uma oportunidade para aumentar os recursos financeiros repassados à saúde, devido

\footnotetext{
${ }^{18}$ A portaria estabeleceu um número máximo de diárias a serem pagas por cada Autorização de Internação Hospitalar (AIH), abrindo a possibilidade de um controle maior, por parte do gestor estadual ou municipal.
} 
ao seu elevado valor, comparativamente aos outros da tabela de remuneração do SUS. Ou seja, estavam mais preocupados com as finanças municipais do que em implantar um modelo de assistência em saúde mental. Esse panorama se amplia a partir de 2002, como veremos mais à frente.

Por outro lado, aquelas e outras portarias publicadas nos anos subsequentes, pelo Ministério da Saúde, permitiram aos estados e municípios exercer maior fiscalização, controle e uma intervenção nos hospitais psiquiátricos privados ou filantrópicos prestadores de serviço ao SUS que não apresentassem condições mínimas de funcionamento. No estado de São Paulo, todos os hospitais psiquiátricos foram submetidos a uma supervisão de avaliação, que resultou no fechamento de vários deles, com significativa redução de leitos psiquiátricos. ${ }^{19}$

Em dezembro de 1992, foi realizada a II Conferência Nacional de Saúde Mental. Precedida de etapas municipais, regionais e estaduais, que contaram com o envolvimento direto de cerca de vinte mil pessoas, a fase nacional reuniu quinhentos delegados eleitos nas conferências estaduais, com composição paritária dos dois segmentos: usuários e sociedade civil, governo e prestadores de serviço. Contou, ainda, com a presença de 320 observadores credenciados, 150 participantes, na condição de ouvintes, 100 convidados (sendo 15 estrangeiros), totalizando mais de mil pessoas ${ }^{20}$ de diferentes partes do país. Eram trabalhadores, gestores estaduais e municipais, políticos, representantes dos hospitais psiquiátricos, representantes de entidades de saúde, associações de usuários e familiares de pacientes, entidades de autoajuda, representantes de universidades, que debateram ativamente os temas propostos.

Em sintonia com o momento do país, ${ }^{21}$ a II CNSM discutiu três grandes temas: crise, democracia e reforma psiquiátrica; modelos de atenção em saúde mental; e direitos e cidadania. $\mathrm{O}$ relatório final subdividia-se em três partes: marcos conceituais; atenção à saúde mental e municipalização; e direitos e legislação.

\footnotetext{
${ }^{19}$ Segundo dados obtidos no site <www.datasus.gov.br), em dezembro de 1992, havia 33.698 leitos psiquiátricos credenciados ao SUS. Em dezembro de 2002, esse número tinha se reduzido a 19.456 leitos.

${ }^{20}$ Dados constantes na apresentação do relatório da conferência.

${ }^{21}$ Todas as etapas da conferência foram realizadas durante o processo de impeachment do presidente Collor.
} 
Realizada em circunstâncias históricas distintas da I CNSM, cujo relatório apresentava diversas proposições de caráter político, o relatório final da II $\mathrm{CNSM}^{22}$ não foi tão contundente na crítica ao modelo econômico, nem ao momento político em que se estava vivendo. Embora aquelas questôes estivessem como pano de fundo, o texto era mais extenso e específico nas questôes da saúde mental. A II CNSM ocorreu em um momento em que diversas experiências estavam consolidadas e espalhando-se pelo país; já existia um projeto de lei federal, aprovado na Câmara dos Deputados e tramitando no Senado, e leis estaduais aprovadas ou em tramitação; ${ }^{23}$ havia dispositivos institucionais (portarias ministeriais) voltadas para a implantação de novos serviços e aumentavam a fiscalização dos hospitais; existiam diversas associações de usuários atuando ativamente pelo país, isto é, estava em curso um processo de transformação da saúde mental no campo assistencial, no campo jurídico, no campo institucional e no campo cultural. O relatório apresentava importantes elementos para compreender esses diferentes aspectos do processo de transformação. Destaca-se o seguinte trecho, o qual focaliza o entendimento sobre o processo saúde-doença adotado e defendido pela Reforma Psiquiátrica:

III. O processo saúde/doença mental deverá ser entendido a partir de uma perspectiva contextualizada, onde qualidade e modo de vida são determinantes para a compreensão do sujeito, sendo de importância fundamental vincular o conceito de saúde ao exercício de cidadania, respeitando-se as diferenças e as diversidades. (Brasil, 1994: 11)

O relatório sintetiza ainda alguns pontos importantes na articulação entre a atenção integral e a cidadania, com claros reflexos naquilo que hoje nomeamos como mudança do modelo assistencial:

IV. A vida exige uma abordagem abrangente no campo da Saúde Mental, capaz de romper com a usual e ainda hegemônica concepção compartimentalizada do sujeito, com as dissociações mente/corpo e trabalho/prazer (...). Refletida em: a) Mudança no modo de pensar a pessoa com transtornos mentais em sua

${ }^{22}$ Em trabalho anterior, Costa-Rosa, Luizio e Yasui (2001) analisam o relatório final das duas conferências nacionais de Saúde Mental.

${ }^{23}$ Aprovaram leis com orientação semelhante ao projeto do deputado Paulo Delgado os estados: Rio Grande do Sul (1992), Pernambuco (1992), Espírito Santo (1992), Ceará (1993), Minas Gerais (1995) e Paraná (1995); o Distrito Federal (1995), além de municípios, como, por exemplo, Ribeirão Preto-SP, Belém-PA e Londrina-PR. 
existência sofrimento, e não apenas a partir do seu diagnóstico; b) Diversificação das referências conceituais e operacionais, indo além das fronteiras delimitadas pelas profissões clássicas em Saúde Mental; c) uma ética da autonomia e singularização que rompa com o conjunto de mecanismos institucionais e técnicos em Saúde, que têm produzido, nos últimos séculos, subjetividades proscritas e prescritas. (Brasil, 1994: 11-2)

Muitas das propostas apresentadas se concretizaram, como, por exemplo, a criação da Comissão Nacional de Reforma Psiquiátrica em dezembro de 1993. Nesse sentido, o relatório da II CNSM apontou para a consolidação das conquistas e para onde avançar.

Nos anos 90, utilizando-se da mesma estratégia do Movimento Sanitário, a Reforma Psiquiátrica institucionalizou-se enquanto política oficial, conquistando seu território no interior do aparelho estatal. E procurou não se afastar de suas raízes, suas origens. Na mesma II CNSM, a presença de centenas de delegados, usuários e familiares indicava para as novas alianças que a reforma estabelecia e fortalecia: as associações e organizações sociais. Dessa forma, setores do movimento mais identificados com o Movimento da Luta Antimanicomial retomaram a sociedade civil e o plano cultural como palco de lutas e conquistas. Privilegiando a articulação e a ampliação das alianças com outros segmentos da sociedade, estenderam o movimento para além do campo da saúde mental, incorporando definitivamente novos atores, buscando obter o apoio da sociedade a essa luta. Os anos 90 foram férteis, também, em encontros e eventos com a participação ativa das associaçôes de usuários e familiares, além de outros setores da sociedade.

Em setembro de 1993, foi realizado, em Salvador, o I Encontro Nacional da Luta Antimanicomial. Os trabalhos se desenvolveram em torno de um tema comum que caracterizava o MLA como um movimento social, plural, independente, autônomo e que devia manter alianças com outros movimentos sociais. Marcava um avanço de movimento identificado como dos Trabalhadores de Saúde Mental para um movimento social mais amplo, "saindo de um caráter meramente teórico e técnico, para uma intervenção política na sociedade" (Relatório do I Encontro da Luta Antimanicomial, apud Conselho Regional de Psicologia, 1997: 65).

O relatório final do encontro detalhava ainda os seguintes aspectos: afirmava que a situação social, política e econômica do país era produtora de sofrimento e indicava a necessidade de inserir a questão da saúde mental 
em todos os movimentos sociais; apresentava uma reflexão sobre o fazer clínico, que "deve ser pensado como ato político" (idem, p. 68); destacava a assistência em saúde mental como a construção de práticas de atenção integral à saúde num processo coletivo, contemplando a cultura, a interdisciplinaridade, os movimentos populares, sindicais, comunitários e legislativos.

De maneira geral, o MLA denunciava que "a política ministerial procura ser uma equação entre a perspectiva do movimento e os interesses empresariais no setor; o que na prática tem favorecido a permanência do parque asilar do Brasil” (idem, p. 79). Buscava, assim, colocar-se em uma posição de independência em relação ao aparelho estatal, sendo cuidadoso quanto à participação na política oficial de saúde mental. Por outro lado, colocou-se como importante interlocutor do Ministério, ao compor a Comissão Nacional de Reforma Sanitária, do Conselho Nacional de Saúde, como um dos representantes do segmento da sociedade, ao lado de representantes dos usuários, dos hospitais etc., seguindo a mesma distribuição paritária entre segmentos da sociedade e do governo das demais comissões da Saúde.

Essa foi e é uma questão permanente para o MLA, que tentava manter uma característica predominantemente de movimento social, ainda que muitos de seus importantes atores estivessem exercendo o papel de gestores de políticas municipais de saúde. Isso assinalou uma importante diferença em relação a outros segmentos da Reforma Psiquiátrica, que aderiram ou se instalaram no aparelho de Estado, afastando-se do cotidiano da assistência.

No ano de 1993 foi realizado, na cidade de Santos (SP), o III Encontro Nacional de Usuários e Familiares, ${ }^{24}$ no qual foi redigida a "Carta de Direitos dos Usuários e Familiares de Serviços de Saúde Mental”. De forma geral, o texto da "Carta de Direitos" não traz novidades em relação a outros documentos, reafirmando, basicamente, os princípios e diretrizes defendidas pela Reforma Psiquiátrica. A novidade foi o processo de sua elaboração. Um texto discutido e debatido pelos usuários e familiares. O louco, destituído de sua condição de cidadão, afirma-se como sujeito de seu tempo e escreve, literalmente, uma página de sua história. Os vários encontros que precederam e a própria Carta reiteram a identidade dos movimentos dos

${ }^{24}$ O I Encontro Nacional foi realizado na cidade de São Paulo, em 1991; o II Encontro, na cidade do Rio de Janeiro, em 1992. 
familiares e usuários como um movimento social que vai conquistando espaço e características próprias.

Desse momento em diante, houve uma frequência de encontros nacionais a cada dois anos, tanto do Movimento da Luta Antimanicomial, quanto do Movimento dos Usuários e Familiares.

Desde seu início, nos anos 70, a Reforma Psiquiátrica se apresentou com um temário de caráter social e estabeleceu estratégias para ampliar os limites de sua atuação para além dos muros dos asilos e das universidades. Em um constante processo dialético, foram sendo criados novos paradigmas e novas práticas institucionais, especialmente os Naps e os Caps, que acabaram por influenciar e inspirar mudanças na estrutura normativa das ações de saúde, através das portarias e normatizações do Ministério da Saúde, constituindo-se, assim, como uma política pública de saúde. Tensionando essa característica burocrático-administrativa, o Movimento da Luta Antimanicomial, a face política mais ativa da Reforma Psiquiátrica, manteve 'os pés na origem' como movimento social, congregando diversos setores da sociedade, tais como: associaçóes de usuários e familiares, conselhos de profissionais, sindicatos, centrais sindicais, parlamentares e outros mais, formando um amplo leque de alianças.

Enquanto a Reforma Sanitária optou por continuar a investir prioritariamente na estratégia de ocupação estatal, a Reforma Psiquiátrica, ao contrário, superando os limites de um movimento específico animado por trabalhadores, foi ampliando alianças, atualizando e renovando a sua luta, radicalizando, segundo Amarante (1999), os princípios da Reforma Sanitária descritos pelo médico-sanitarista Nelson Rodrigues dos Santos: inclusão, solidariedade, cidadania.

\section{O NOVO MILÊNIO: DESINSTITUCIONALIZAR A REFORMA PSIQUIÁTRICA}

O milênio se iniciou com uma vitória de sabor amargo. Após quase doze anos tramitando no Senado Federal, em 2001, ano escolhido pela OMS como o ano da saúde mental, foi finalmente assinada a lei n. 10.216, que dispõe "sobre a proteção e os direitos das pessoas portadoras de transtornos mentais e redireciona o modelo assistencial em saúde mental", a 
chamada lei da Reforma Psiquiátrica. Seu texto final está muito distante do saudável radicalismo do projeto original, aprovado em 1989, o qual propunha claramente a "extinção progressiva do manicômio e sua substituição por outros serviços". No primeiro, temos uma proposta de substituição de modelo e, no outro, de proteção, de direitos e redirecionamento. A mudança não foi apenas semântica, mas de essência. Transformada em um texto tímido, a lei aprovada mantém a estrutura hospitalar existente, regulando as internações psiquiátricas, e apenas aponta para uma proposta de mudança do modelo assistencial. Como revelador dessa característica, podemos destacar o fato de sete $\left(4^{\circ}\right.$ a $\left.10^{\circ}\right)$, de seus treze artigos, referirem-se exclusivamente à regulamentação da internação psiquiátrica, enquanto dois $\left(1^{\circ} \mathrm{e}\right.$ $\left.2^{\circ}\right)$ aludem aos "direitos e à proteção das pessoas acometidas de transtorno mental". A mudança de modelo de atendimento aparece como uma sugestão no item IX do parágrafo único, do artigo $2^{\circ}$, expressa como direito da pessoa em "ser tratada, preferencialmente, em serviços comunitários de saúde mental". Os outros artigos se relacionam à responsabilidade do Estado, às pesquisas científicas e à criação de uma comissão para acompanhar a implementação da lei.

No mesmo ano, ocorreu a III Conferência Nacional de Saúde Mental em Brasília. Em um curto período de tempo, já que foram apenas seis meses para organizar o processo, realizaram-se 163 conferências municipais e 173 microrregionais e regionais. $\mathrm{Na}$ segunda etapa, todos os 27 estados da federação organizaram as conferências estaduais, totalizando cerca de 20.000 participantes. Na conferência nacional em Brasília, houve 1.480 inscritos regulares, aos quais se somaram cerca de 220 pessoas, que transitaram nas atividades, totalizando a cifra geral de 1.700 participantes. A plenária final para a votação das propostas durou extenuantes 23 horas.

O relatório final é extenso, e a leitura de seus itens já demonstra a complexidade em que se transformou o campo da Reforma Psiquiátrica. Os aspectos mais importantes e as questôes mais polêmicas estão contidos em suas páginas.

Em seu capítulo I, sobre "Reorientação do Modelo Assistencial em Saúde Mental", sustenta, entre os princípios e diretrizes, que a reorientação do modelo assistencial "deve estar pautada em uma concepção de saúde compreendida como processo e não como ausência de doença, na perspectiva de produção de qualidade de vida, enfatizando ações integrais e promocionais de saúde" (SUS, 2002: 23). 
Em seguida, conclama os municípios a desenvolverem políticas de saúde mental que implementem

uma rede de serviços substitutivos ao hospital psiquiátrico, territorializados e integrados à rede de saúde que realize ações de proteção, promoção, prevenção, assistência e recuperação em saúde mental. É fundamental, também, que as novas modalidades assistenciais substitutivas desenvolvam práticas pautadas em relaçóes que potencializem a subjetividade, a auto-estima, a autonomia a cidadania e busquem superar a relação de tutela e as possibilidades de reprodução de institucionalização e/ou cronificação. (SUS, 2002: 23)

O documento apresenta ainda inúmeras propostas dividas em 13 subitens, dos quais destaco: política de saúde mental e organização de serviços; responsabilidades do gestor; desinstitucionalização (superação do modelo asilar; organização e produção da rede e dos serviços substitutivos; serviços residenciais terapêuticos; trabalho e geração de renda); controle da internação psiquiátrica; atenção básica; intersetorialidade; atenção à criança e ao adolescente; e atenção aos usuários de álcool e outras drogas.

No capítulo II, sobre a "Política de Recursos Humanos", destaca a importância da formação desses recursos, de forma integrada, nas três esferas, que valorize e considere a importância do trabalhador de saúde mental na produção dos atos de cuidar, favorecendo o exercício ético da profissão. Expõe diversas propostas subdivididas em itens, dos quais sublinho: política de contratação de recursos humanos; coordenação e gestão das equipes de saúde mental; política de formação, pesquisa e capacitação de recursos humanos em saúde mental no SUS; e capacitação através de parcerias com instituições formadoras e outras instituições.

No capítulo III, sobre o "Financiamento", o relatório propõe que

os recursos financeiros devem acompanhar o usuário nos diferentes espaços de reprodução social e ser viabilizadores de processos emancipatórios. Assim, os recursos devem ser centrados nas pessoas e não nos serviços. O financiamento deve contemplar todas as ações necessárias e decorrentes da implantação, implementação e sustentação de uma nova política de saúde mental, em especial a rede de serviços e a capacitação de recursos humanos. (SUS, 2002: 84)

São contempladas, nos diversos subitens, propostas para financiamento: dos serviços substitutivos; de novas iniciativas, ações e procedimentos 
em saúde mental; de ações intersetoriais de suporte social; da assistência farmacêutica; para pesquisa, formação e capacitação de recursos humanos em saúde mental; e dos mecanismos de comunicação e informação e visibilidade da política de saúde mental.

No capítulo IV, sobre "Acessibilidade", o relatório reafirma a meta de garantia de equidade de acesso a todos os serviços de saúde do SUS aos portadores de transtorno mental, incorporando-a nas agendas de saúde e na programação das ações de saúde.

No capítulo V, sobre "Direitos e Cidadania", ressalta a prioridade para a formulação de políticas que fomentem a autonomia dos portadores de transtornos mentais, incentivando, deste modo, o exercício de cidadania plena, no lugar de iniciativas tutelares. Destaca, também, as propostas relacionadas à inserção no mundo do trabalho, por meio de projetos de geração de renda ou de formação de cooperativas sociais.

No capítulo VI, sobre "Controle Social", como modo de garantir a substituição do modelo hospitalocêntrico e o avanço da Reforma Psiquiátrica, o relatório enfatiza a importância dos conselhos de Saúde, das comissões de Saúde Mental e de outras formas de organização e participação social.

Em 2002, como consequência da III CNSM, uma nova portaria foi publicada, a 336/2002, com importantes diferenças em relação à anterior: abandonou o termo Naps, propondo um novo modelo de assistência, definindo os Caps como "serviço ambulatorial de atenção diária que funcione segundo a lógica do território"; criando três diferentes tipos: "Caps I, Caps II e Caps III, definidos por ordem crescente de porte/complexidade e abrangência populacional"; o Caps passa a ser o articulador central das ações de saúde mental do município ou do modulo assistencial, de acordo com a Norma Operacional de Assistência à Saúde (Noas).

Mudou o financiamento, que passou a ser realizado por Autorização de Procedimentos de Alto Custo (Apac), contando com verbas garantidas pelo Ministério da Saúde. Ou seja, os recursos financeiros para o Caps fazem parte do Fundo de Ações Estratégicas e de Compensação (Faec) do Ministério da Saúde, criado em abril de 1999, pela portaria GM/MS 531/1999, com o objetivo de garantir o financiamento, pelo gestor federal, de procedimentos de alta complexidade ou procedimentos decorrentes de ações consideradas estratégicas. Antes da criação do Faec, o Ministério da Saúde não dispunha de 
instrumentos que permitissem financiar e priorizar ações tidas como estratégicas, pois os recursos federais destinados ao custeio da assistência à saúde estavam alocados nos tetos financeiros dos estados e municípios. Souza (2003: 456) descreve as ações estratégicas como aquelas que

decorrem de políticas de saúde definidas em função das necessidades de grupos prioritários, como é o caso da prevenção do câncer de colo de útero no âmbito da saúde da mulher, ou da necessidade de ampliação do acesso aos serviços de saúde ofertados à população, a exemplo das campanhas de cirurgias eletivas (catarata, próstata, etc). Essas ações apresentavam uma grande demanda reprimida, em virtude da prioridade dada pelos gestores estaduais e municipais à utilização dos recursos financeiros dos seus tetos para outros procedimentos considerados mais urgentes.

Assim, os recursos disponíveis para o pagamento dos procedimentos do Caps, incluídos no Faec, não estão contidos nos tetos financeiros dos estados e municípios e funcionam como recursos 'extrateto'. Se, por um lado, esse modelo de financiamento representou um avanço, porque colocou a proposta de mudança de modelo assistencial implícita, no Caps, como uma política de relevância e uma ação estratégica do Ministério da Saúde; por outro lado, trouxe problemas, pois mantém a mesma lógica de produtividade, ao remunerar atos vinculados a um determinado diagnóstico psiquiátrico de um indivíduo, deixando de lado toda uma série de açôes realizadas no âmbito do território, todas previstas na portaria 336/2002, tais como a supervisão de unidades hospitalares, o apoio matricial a equipes da atenção básica, a articulação com outros setores e segmentos sociais etc. Continua-se a financiar a doença e não a promoção da saúde. Flávia Freire (2004) examina esse modelo de financiamento e suas implicações na assistência em saúde mental, detalhando essa análise.

Se, ao longo dos anos 90, a Reforma Psiquiátrica manteve estreita relação com os movimentos sociais, no raiar deste novo milênio começa a padecer do mesmo mal que acometeu a Reforma Sanitária. Como destaquei anteriormente, o processo de institucionalização da Reforma Sanitária, por um lado, foi um passo importante e decisivo para a consolidação de um projeto de saúde que se contrapõe ao modelo hegemônico, por outro, encaminhou-a para longe dos movimentos e das organizaçóes sociais, deslocando seu principal foco de luta da sociedade civil para o interior do aparelho estatal. Para Stotz (1994) o Estado passa a ser visto como um sujeito, diante 
do qual outros sujeitos se situam, despojados de suas encarnações sociais e de poder, para produzir a política pública. Tem-se a impressão de que os principais atores estão nos gabinetes ministeriais, produzindo normas e portarias, e não estão mais nas forças vivas da sociedade, nas instituições e nos serviços, como ativos protagonistas políticos.

Essa ênfase nos processos de regulação como indutores da política do SUS transforma a potencialidade criativa e transformadora daqueles atores em uma servidão às normas e portarias. Não há mais oposição, tensão, questionamento. Pelo contrário, as críticas, geralmente oriundas dos setores acadêmicos, passam a ser vistas como ataque ou obstáculo a um processo que, ao se institucionalizar, perdeu a sua dimensão histórica e parece obedecer apenas uma lógica de administração dos recursos financeiros disponíveis, afetando de maneira danosa o modelo assistencial. Arouca afirmava a urgente necessidade de se retomar os princípios básicos do SUS, dentre os quais o conceito saúde/doença ligado ao trabalho, ao saneamento, ao lazer e à cultura, o que implica discutir "a saúde não como política do Ministério da Saúde, mas como uma função de Estado permanente". Arouca (2002: 19) destacava o dano das políticas econômicas ao SUS, com a seguinte argumentação:

O modelo assistencial é anti-SUS. Aliás, o SUS como modelo assistencial está falido, não resolve nenhum problema da população. Essa lógica transformou o governo num grande comprador e todas as outras instituições em produtores. A Saúde virou um mercado, com produtores, compradores e planilhas de custos. O modelo assistencialista acabou universalizando a privatização.

Campos (1992) já alertava, no início dos anos 90, para a necessidade de se repensar a Reforma Sanitária, recolocando a importância do cotidiano dos serviços, com seus processos de trabalho e de gestão, com seus atores com necessidades, potencialidades e demandas, enfim, com sua micropolítica, como estratégia de transformação.

A Reforma Psiquiátrica se ressentiu do mesmo problema. A sua institucionalização transformou o Ministério da Saúde no principal ator e indutor-chefe dos ritmos e dos rumos desse processo. Parece não haver mais espaço para experiências que não sigam os parâmetros estabelecidos nas portarias, que, ironicamente, têm como inspiração as experiências do Caps e dos Naps, as quais trazem a marca da invenção e da criação com que se construíram e obtiveram seu reconhecimento antes de tais regulaçóes. 
Se as portarias 189/1991 e 224/1992 incentivaram a criação de diversas unidades assistenciais espalhadas pelo país, muitas com o nome de Naps ou de Caps, que acabaram por se transformar em sinônimos de unidades assistenciais de vanguarda, a portaria 336/2002, em função da mudança no financiamento, está contribuindo para a ampliação do número de Caps num ritmo muito mais veloz.

Uma primeira e óbvia questão surge: implantar um serviço com a 'marca' Caps não significa automaticamente uma adesão, tanto dos trabalhadores quanto dos gestores, aos princípios, às diretrizes e aos novos paradigmas propostos, nem é a garantia de um serviço de qualidade e de substituição aos manicômios. Um crucial equívoco é o fato de o Caps ser considerado e implantado como mais um serviço de saúde mental. Isto é, uma unidade isolada em que se executam ações de profissionais, ambulatorialmente. O Caps, mais do que um serviço, é uma estratégia de mudança do modelo de assistência que inclui necessariamente a reorganização da rede assistencial, a partir de uma lógica territorial, o que significa ativar os recursos existentes na comunidade para compor e tecer as múltiplas estratégias de cuidado implícitas nessa proposta. E, mais do que reorganização, essa estratégia relaciona-se intimamente com uma proposta política de organização e de assistência à saúde.

Como já mencionei anteriormente, Rotelli, Leonardi e Mauri (2001) chamam a atenção para um processo ocorrido na Europa e nos Estados Unidos, nomeado como psiquiatria reformada, no qual foram criados serviços territoriais que conviviam com a internação sem, no entanto, substituí-la. Como consequência, o sistema de saúde mental se transformou em um circuito autoalimentado, em que a segregação em uma instituição total foi substituída pela dinâmica da circulação entre serviços especializados pontuais e fragmentados. Segundo eles, houve uma desospitalização e não uma desinstitucionalização, ou seja, houve apenas um processo de mudança de instituição, sem nenhuma transformação. Rotelli, Leonardis e Mauri (2001: 24) acrescentam:

A intenção de liberar a Psiquiatria (e o seu objeto) da coação e da cronicidade que esta produzia para restituir-lhe o estatuto terapêutico resultou na construção de um sistema complexo de prestaçóes que, reproduzindo e multiplicando a lógica somente negativa da desospitalização, selecionam, decompõem, não se responsabilizam, abandonam. 
Este é um risco presente no atual processo da Reforma Psiquiátrica. Embora inspirados em ideais e princípios de transformação assistencial, corremos o risco de produzir apenas uma tímida desospitalização.

Do ponto de vista quantitativo, encontramos, hoje, um grande número de instituições cadastradas no SUS como Caps, ${ }^{25}$ o que poderia nos induzir a pensar que a assistência estaria melhor, na mesma proporção. Porém, a internação psiquiátrica, embora em declínio, ${ }^{26}$ ainda continua sendo a estratégia hegemônica de tratamento. ${ }^{27}$ Por outro lado, a minha prática profissional tem demonstrado que muitas das instituições nomeadas como Caps estão distantes de oferecer um serviço de qualidade, norteado pelos paradigmas da Reforma Psiquiátrica.

Em muitos casos, a lógica financeira prevalece sobre a proposta de mudança de modelo, por exemplo, quando gestores municipais implantam Caps apenas motivados pela possibilidade de um acréscimo de recursos ao seu teto financeiro. ${ }^{28}$ Certa ocasião, ouvi que o gestor de município estimulava os profissionais do Caps com um prêmio de incentivo por Apacs produzidas. Dessa forma, não importa a qualidade da assistência, importa que o paciente assine a Apacs, que o município receba o recurso financeiro, que, ao final, pode ser utilizado em outras açôes de saúde do município, que não a saúde mental, já que as verbas são sempre insuficientes etc. $\mathrm{O}$ trabalho dos profissionais acaba se precarizando, pois não há, por parte desse tipo de gestor, um investimento na organização e no fortalecimento das ações, levando as equipes a executar, em muitos casos, apenas as ações mais convencionais. $\mathrm{O}$ trabalhador, que era um ativo protagonista político, inventor de possibilidades de intervenção e produção de cuidados, tornou-se mero reprodutor acrítico das normas ministeriais. Muitos gerentes de serviços, por tal pressão, acabam

${ }^{25}$ De acordo com o informativo Saúde Mental em Dados n. 7 do Ministério da Saúde, disponível em <http://portal.saude.gov.br/portal/arquivos/pdf/smdados.pdf>, até junho de 2010 estavam cadastrados 1.516 Caps.

${ }^{26}$ Segundo o mesmo informativo, entre 2002 e 2009, houve uma redução de mais de 30\% no número de leitos psiquiátricos no país.

${ }^{27}$ Embora o mesmo informativo aponte para uma importante reversão do gasto com ações hospitalares, de 75\% do orçamento em 2002 para 32\% em 2009, há ainda uma lógica hospitalocêntrica que norteia as ações dos profissionais.

${ }^{28}$ Em função do tipo de financiamento, em alguns municípios pequenos, o recurso enviado pelo Ministério ao Caps era igual ou superior ao Piso da Atenção Básica (PAB). Isto até a mudança proposta e implementada pelo Pacto pela Saúde, a partir de 2006, que modificou este panorama. 
cedendo e estão mais preocupados com a sobrevivência econômica da engenharia institucional do que com a clínica dos casos.

Por outro lado, temos, com frequência, profissionais que se veem com a incumbência de implantar um serviço complexo como o Caps, sem os recursos teóricos e técnicos para tal tarefa. Em decorrência, não conseguem efetivar um trabalho que proporcione, minimamente, um espaço de acolhimento ao sofrimento, à diferença. Pelo contrário, acabam reproduzindo o saber e as práticas que conhecem, criando, assim, lugares onde o modelo hegemônico novamente prevalece: mantém uma rígida estrutura verticalizada; o saber e as condutas médicas preponderam; a divisão de trabalho é rígida; objetiva-se a supressão sintomática; enfoca-se exclusivamente a doença. Aquilo que deveria ser a atenção psicossocial é assim construída cotidianamente num processo que reproduz uma mesma lógica manicomial, perpetuando uma prática que, sem ser executada no interior dos altos muros dos asilos, exclui e segrega. No lugar de um processo de transformação assistencial, norteado por princípios éticos, temos a reprodução. Minimanicômios de portas abertas e mentes fechadas. Apenas uma psiquiatria reformada.

\section{PARA NÃO CONCLUIR...}

Em tempos de globalização econômica, radicalização da dependência internacional, o neoliberalismo aponta para um Estado mínimo que abandona os investimentos nas áreas sociais, bem como amplia e refina dispositivos de manutenção do poder econômico por meio de políticas de exclusão e controle. Há cada vez mais concentração de renda, mais injustiça social, mais desemprego, e menos manifestações populares de protesto, menos articulações de oposição. Sindicatos negociam redução de salários em troca de estabilidade de emprego. Capturados pela lógica econômica neoliberal, a solidariedade cede terreno ao individualismo. Cinismo e violência ganham destaque e relevância. Há menos cultura popular e mais narcisismo em tempos sombrios. ${ }^{29}$ Parece que nada há para além do jardim da globalização neoliberal.

Individualização excessiva, letargia, fascínio pelo banal apresentado como espetáculo, anti-historicismo do cotidiano são alguns dos elementos que se

${ }^{29}$ Referência ao texto de Jurandir Freire Costa (1988), "Narcisismo em tempos sombrios". 
apresentam para a produção de nossas subjetividades de final de milênio: desagregadas e isoladas, facilmente controláveis e, no mais das vezes, ávidas por se incluírem no restrito e inacessível grupo dos privilegiados.

Santos (2001) aponta para a crise da sociedade moderna, discutindo vários de seus aspectos e destacando o fracasso das promessas de progresso que, ao final do século XX, tinham se transformado em ameaças de destruição, salientando a crise epistemológica do paradigma dominante da racionalidade científicas, que, desde o início do século passado, vem sofrendo abalos profundos em suas verdades. Ele caracteriza a pós-modernidade, na falta de um outro termo melhor, como momento de transição paradigmática, de profundas e necessárias mudanças e transformaçôes.

É nesse cenário que os atores dos movimentos sociais - e dentre eles a Reforma Psiquiátrica - encontram seu grande desafio: não apenas negar o manicômio, mas produzir e inventar espaços de encontro para a problematização do cotidiano, para a formulação de novas questões; espaços para produção de rupturas, para radicalização das contradições; espaços para a afirmação da vida.

O campo da Reforma Psiquiátrica tornou-se complexo. Essa complexidade traz a marca da diversidade de atores que o constituem: trabalhadores de saúde, gestores, usuários, familiares, parlamentares, acadêmicos, pesquisadores, estudantes e simpatizantes de diversos segmentos sociais. Nascida sob a égide de uma luta política contra a ditadura e o autoritarismo, a Reforma Psiquiátrica nunca deixou de ser esse campo político por excelência: lugar de disputas, de confrontos, de alianças, de contradições. A proposta de ruptura radical com um determinado modelo de entendimento e de cuidado ao sofrimento humano produziu, no seu cotidiano histórico, discursos sobre esse sofrer, modos de cuidar e lugares que enunciavam esses mesmos discursos.

São discursos que se constituem como campos de saber, de produção de verdades. E, segundo Foucault (2004: 10), necessariamente, de produção de poder, visto que "o discurso não é simplesmente aquilo que traduz as lutas ou sistemas de dominação, mas aquilo por que, pelo que se luta, o poder do qual queremos nos apoderar".

Roberto Machado (1988: 199), ao analisar a genealogia do poder, em Foucault, enfatiza: 
Não há saber neutro. Todo saber é político. E isso não porque cai nas malhas do Estado e é apropriado por ele, que dele se serve como instrumento de dominação, desvirtuando seu núcleo essencial de racionalidade. Mas porque todo saber tem sua gênese em relações de poder (...) não há relação de poder sem constituição de um campo de saber, como também, reciprocamente, todo saber constitui novas relações de poder.

Se, nos últimos anos, a Reforma Psiquiátrica fortaleceu-se como política pública, conquistando reconhecimento que se transformou em poder técnico-administrativo de regulação, houve, por outro lado, um enfraquecimento como movimento social. As recentes cisões no Movimento da Luta Antimanicomial, tensões e antagonismos públicos de segmentos sociais com os condutores da gestão da política ministerial demonstram que parece haver uma luta pelo lugar da autoridade de quem possui a verdade do discurso sobre o campo das transformações produzidas pela reforma. Parece a instauração do lugar da autoridade e o estabelecimento de campos de domínio de saber e de poder. Eis o risco iminente de um lado negro e obscuro da reforma. Constituir-se como um campo de saber/poder e reproduzir, na prática de seus atores, uma mesma lógica de dominação e exclusão. Não são apenas os profissionais do Caps que devem estar atentos para a permanência do antigo paradigma.

Sempre corremos riscos. Como nos alerta Foucault (2003: 8),

meu objetivo será mostrar-lhes como as práticas sociais podem chegar a engendrar domínios de saber que não somente fazem aparecer novos objetos, novos conceitos, novas técnicas, mas também fazem nascer formas totalmente novas de sujeitos e de sujeitos de conhecimento. O próprio sujeito de conhecimento tem uma história, a relação do sujeito com o objeto, ou, mais claramente, a própria verdade tem uma história.

Se nossa prática gera saberes, não há como negar, também, que gera poderes nos microcosmos desses novos serviços, os quais hoje se transformaram em uma ação de Estado. Qual o efeito que tal poder estará produzindo? Efetivará uma ruptura que promova a emergência ou a constituição de novas subjetividades mais autônomas, mais livres? Ou, cooptado e esvaziado de sua potencialidade transformadora, será reduzido a mais um dispositivo de controle e de dominação? 
Nestes tempos difíceis, é hora de retomarmos a sociedade civil, atuar na "microfísica" das instituições e do poder, produzir efeitos e incitar os movimentos sociais. Com o olhar, a escuta e o pensamento crítico, produzir tensões e conflitos para enfrentar a mesmice, a pasmaceira e a servidão cega e voluntária que hegemonicamente dominam nossos horizontes. É tempo de voltar a fazer política, de sermos atores protagonistas na construção de um novo tempo. Não podemos esquecer que, se fizemos história, foi para construir outro rumo. Voltar a fazer dos nossos atos o milagre de produzir o novo, de acontecer, tal como formulado por Hannah Arendt e a que nos referimos, no início do capítulo.

É preciso desinstitucionalizar certos aspectos da Reforma Psiquiátrica para torná-la um conceito 'forte'. 



\section{2}

\section{A REFORMA PSIQUIÁTRICA E A TRANSIÇÃO PARADIGMÁTICA}

O real não está na saida nem na chegada, ele se dispóe pra gente é no meio da travessia.

Guimarães Rosa

“- Os raios de sol estão me atravessando."

Seu rosto crispado pela angústia denunciava o sofrimento de Zé. Em uma paulistana manhã fria de inverno, enquanto outros usuários estavam no sol para se aquecer, sentei-me ao seu lado. Essa frase, dita ao vento sem direção, me tomou por inteiro. Alucinação? Vivência psicótica? Todavia, logo meu pensamento se voltou para algo mais próximo. Lá estava ele, com aquela fisionomia marcada por uma profunda dor. A única coisa que pude pensar foi: “- Então vamos sair do sol”. Falei alto o que pensei. Olhou para mim e disse: “- Vamos! Fica comigo?". Caminhei ao seu lado para dentro do casarão do Caps. Na sombra, a angústia de seu rosto se desfez. Perguntou-me se não queria jogar tênis de mesa. Terminamos aquela fria manhã numa intensa e aquecedora partida.

Neste pequeno fragmento de cena que vivenciei no Caps Luiz Cerqueira, duas diferentes aproximações: na primeira, olhava para aquela dor, buscando defini-la e enquadrá-la em algum critério semiológico que me ajudasse a determinar um provável diagnóstico. Definido o quadro, poderia, então, pensar na melhor conduta, no melhor agir para aquele momento. Colocava em ação um arsenal teórico-conceitual, que busca objetivar aquelas sensaçôes e sentimentos, transformando-os em sintomas de uma doença. 
Em um segundo momento, percebi que havia algo mais a ser ouvido. Havia na dor e na angústia daquelas palavras algo que pedia tradução. Um sofrimento que buscava sentido. Um desafio complexo. Corri o risco e interferi na relação, propondo algo que pudesse ao menos possibilitar um encontro. Inventamos uma saída, ainda que momentânea, para aquela angústia ou para aquele frio.

Doença do corpo ou sofrimento psíquico? Relação positiva entre o sujeito do saber e o seu objeto ou encontro intersubjetivo? Padrões protocolados de conduta ou intervenção/invenção criadora? Diferentes formas de olhar e de ouvir que implicam diferentes formas de atuar e intervir. Modelos de discursos, de produções de saber e de práticas sobre a realidade: um, que representa um modelo hegemônico de pensar e nos fala de uma racionalidade científica médica com suas características (isolar, observar, classificar, determinar); outro, que se espanta com o acaso e o incorpora, buscando compreender esse complexo mosaico do viver e do sofrer.

Modos de pensar, ver, escutar e compreender a realidade que se contrapõem em muitos aspectos. Neste raiar do século XXI, os debates nascidos em meados do século passado sobre um profundo questionamento das bases da racionalidade moderna, fundamento da racionalidade médica, ganham na agenda da saúde um importante espaço. De Bachelard a Morin, de Canguilhem a Foucault, para ficar apenas em alguns autores, muito se tem produzido sobre uma crítica ao paradigma científico moderno e a sua crise que afeta e modifica a produção de saberes em distintos campos.

Credita-se a Thomas Kuhn a ampla divulgação e utilização do conceito de paradigma. Para o autor, a ciência caminha por rupturas ou revoluçóes. ${ }^{30}$ O interesse nesse conceito está em contrapor a ideia de que há uma linearidade e continuidade na produção científica que leva ao seu progresso. Kuhn (2000) estabelece um momento que nomeia de "ciência normal", no qual há uma série de suposiçôes, métodos e problemas típicos, que determinam para uma comunidade científica quais são as questōes importantes e qual a melhor maneira de responder a elas, ou seja, há um paradigma. Uma revolução científica acontece, quando surgem "anomalias", isto é, fenômenos ou fatos que não são explicados pelo paradigma vigente e que obrigam a comunidade científica a produzir um novo paradigma, inexistente até então.

${ }^{30}$ Gaston Bachelard foi o primeiro a utilizar o conceito de "ruptura epistemológica", conforme abordarei mais à frente. Destaco aqui que Almeida Filho (2000) aponta para algumas intrigantes coincidências conceituais entre o texto de Bachelard e o de Kuhn. 
Embora sofra muitas críticas por algumas limitações e imprecisões, especialmente por atribuir apenas à comunidade científica o processo de crise e de produção de um novo paradigma, deixando de lado os fatores e determinantes sociais (Vasconcelos, 2002), é um dos conceitos mais empregados em epistemologia. Vários autores, com usos e sentidos diferentes, o retomam como, por exemplo, no conceito de "transição paradigmática" de Boaventura Souza Santos (1987, 2001), e em Morin (2002), por meio do "paradigma da complexidade".

É em um contexto de crítica ao paradigma científico e de sua racionalidade que o processo da Reforma Psiquiátrica desvenda uma importante ruptura com o modo psiquiátrico de olhar e compreender essa estranha e complexa experiência humana que podemos genericamente nomear de loucura. Para Amarante (2003), há uma dimensão epistemológica na Reforma Psiquiátrica que se caracteriza pelo conjunto de questôes situadas na produção dos saberes e que demandam a desconstrução dos conceitos fundantes da psiquiatria, tais como doença mental, alienação, isolamento, terapêutica, cura, saúde mental, normalidade, anormalidade. Além disso, suscitam a reconstrução/invenção de um novo marco teórico e de novos operadores conceituais.

Trata-se não apenas de um novo olhar para o mesmo objeto, mas de uma ruptura epistemológica que descortina um campo complexo de dimensões do real e nos instiga a produzir conhecimento sobre as relações possíveis de serem feitas, construídas, tecidas. Produção de novos conceitos para novos problemas e objetos.

Produção em consonância com o debate sobre a ciência moderna que aponta, também, a uma "nova aliança”, entre as ciências humanas e naturais, como ressaltam Prigogine e Stengers (1997), e para a emergência de um novo paradigma nas ciências: um conhecimento prudente para uma vida decente, como proposto por Boaventura Souza Santos (1987, 2001, 2004); um paradigma da complexidade, como nomeia Morin (2002); ou um novo paradigma ético-estético-político, como postula Guattari (1992).

Neste capítulo, pretendo traçar algumas características do paradigma da racionalidade científica moderna e de seus efeitos na racionalidade médica e psiquiátrica. A seguir, situo o processo da Reforma Psiquiátrica no interior da crise dessa racionalidade, indicando para um período de transição entre paradigmas, destacando as características de um paradigma emergente. Longe de esgotar tão complexo tema, tenho como objetivo fornecer 
alguns elementos que possam contribuir para uma reflexão sobre as características, implicações e consequências dessa dimensão epistemológica.

\section{RACIONALIDADE CIENTÍFICA MODERNA}

Para Touraine (2002), a ideia da modernidade, em sua forma mais ambiciosa, é a afirmação de que o homem é o que ele faz, o que estabelece uma estreita correspondência entre a produção, tornada mais eficaz pela ciência, a organização da sociedade, regulada pela lei, e a vida pessoal, animada pelo interesse e pela vontade de se libertar de todas as opressóes.

Essa correspondência entre cultura científica e uma sociedade ordenada e de homens livres repousa sobre o triunfo da Razão. Somente ela estabelece uma relação entre a ação humana e a ordem do mundo, "anima a ciência e suas aplicações, comanda a adaptação da vida social às necessidades individuais e coletivas e substitui a arbitrariedade e a violência do Estado, pelo direito e pelo mercado" (Touraine, 2002: 9), proporcionando à humanidade o progresso rumo à abundância, à liberdade e à felicidade. Esse é o ideário da modernidade, que tem na racionalidade científica um dos seus pilares de sustentação. Um olhar mais atento sobre a condição da humanidade, neste início de milênio, o qual será retomado mais adiante, basta para demonstrar o quanto esse ideário, séculos após, não se cumpriu.

A racionalidade científica da modernidade nasceu no século XVI, não de uma evolução ou de um acúmulo de saberes, mas de uma ruptura de visão e de uma organização de mundo caracterizado como um saber contemplativo, teocêntrico, formal e finalista, no contexto de profundas transformações econômicas, sociais, políticas e culturais, iniciadas com a Renascença, que caracterizaram a transição do mundo feudal para a modernidade.

Tal ruptura não criou apenas uma cisão entre o divino e o humano. A Natureza não será mais vista como um conjunto de forças situado para além da compreensão humana, com a qual o homem deve relacionar-se com reverência, temor, cumplicidade, conjuração, identificação. Essa ruptura criou uma cisão "também entre ordem humana e ordem natural. Separam-se Deus, homem e natureza" (Luz, 2004: 45). Somente a Razão permite operar com os fenômenos naturais, para submetê-los ao poder do homem, à sua dominação. A Natureza foi esvaziada de uma alma, isto é, de um poder que tanto podia auxiliar quanto aterrorizar. A Razão produziu um "desencantamento" 
do mundo, como nos fala Max Weber (2004). Por isso, o progresso do conhecimento é o progresso do domínio e o Iluminismo é a passagem do mito à Razão esclarecida. O homem afirmou-se como senhor da Natureza.

Madel Luz cita Fritjof Capra, o qual, em seu livro Ponto de Mutação (2004), enfatiza as metáforas utilizadas no início do século XVII, pelo filósofo Francis Bacon, sobre a relação entre o homem da ciência e a Natureza, que deveria ser "acossada em seus descaminhos", "obrigada a servir", "escravizada", com o objetivo de "extrair da natureza, mesmo sob tortura, todos os seus segredos".

A existência objetiva e independente da Natureza é condição epistemológica e ontológica para que o homem possa exercer sobre ela o seu domínio, conhecendo, moldando, transformando, impondo a sua marca: a ordem da Razão. Ao perder o caráter de divino e ao ser dissociada do humano, a Natureza ganhou uma objetividade material, passou de força a coisa: tornou-se objeto. E a Razão, sujeito do conhecimento. Luz (2004: 52) complementa: "A razão torna-se, assim, condição fundamental de apropriação do objeto pelo sujeito, de sua sujeição. Mas trata-se de uma razão instrumentada pela observação repetida, repertoriada, tecnificada. Uma razão demiúrgica, construtora”.

Os filósofos da Escola de Frankfurt, como Adorno, Benjamin, Horkheimer, Marcuse e Habermas, ${ }^{31}$ nomearam essa relação entre o sujeito do conhecimento e o seu objeto, norteada pela necessidade de dominar e controlar, como Razão Instrumental ou Razão Iluminista. Domínio e controle se exercem sobre a Natureza, por meio de uma formalização metódica, matematizante, retirando sua força, sua vida: reificando-a. E se exercem também sobre a sociedade, sobre os homens. Os fenômenos da ordem humana submetem-se a essa Razão Instrumental, tornando-se objetos manipuláveis, negando a sua dimensão histórica e a sua dimensão humana. A reificação do sujeito é, nessa perspectiva, a única possibilidade de conhecêlo. Somos objetos, coisas, subjugados a uma administração regida pelos parâmetros da racionalidade instrumental. Como consequência, nós nos alienamos de nossas ações como sujeitos construtores da história. Na realidade sócio-histórico-cultural, não existem as contradições entre os diferentes interesses humanos. Existe apenas um grande projeto racional que, ao

\footnotetext{
${ }^{31}$ Algumas obras em que esse conceito pode ser encontrado: Adorno e Horkheimer (1985); Marcuse (1969) e Habermas, (1980). Para uma síntese da Teoria Crítica da Escola de Frankfurt, ver Freitag (1994).
} 
final e ao cabo, nos levará à felicidade. Trata-se aqui de um projeto ideológico. As ideias de progresso técnico e neutralidade científica sucumbem à lógica que determina a adequação dos meios aos fins, das necessidades do mercado da sociedade capitalista. Não mais reflexão sobre valores, porém, sim, sobre eficiência e eficácia.

Para Foucault (1979), a apropriação do objeto pelo sujeito do conhecimento tem seus ritos e critérios. A Verdade não é descoberta, elucidada como numa trama de investigação policial, em que se espreita à espera de um momento certo para desvendá-la, revelá-la. De forma diferente, tem instantes propícios, lugares privilegiados, não só para sair da sombra, como para realmente se produzir. Podemos encontrar toda uma 'tecnologia' desta verdade: levantamento de suas localizaçooes, calendário de suas ocasióes, saber dos rituais. A racionalidade científica, com seu rigor e critério, constitui-se em um modo de produzir verdades.

O laboratório é o lócus privilegiado dessa produção. Retira-se o objeto da complexidade da Natureza isolando, esquadrinhando, criando e controlando circunstâncias e momentos, busca-se reproduzir, observar e deduzir conclusões sobre ele. É entre quatro paredes que a verdade sobre o objeto deverá ser submetida ao ritual de sua prova final, de verdade, com critério, lógica e rigor.

O rigor científico é garantido pelo rigor dos cálculos e das medições. Ao extrair da matemática sua lógica de investigação e seu instrumento privilegiado de análise, têm-se duas principais consequências que caracterizam o método da racionalidade científica moderna: a primeira é que conhecer significa quantificar. As qualidades do objeto serão menos importantes do que as suas características que possam ser quantificadas e mensuradas. A segunda é que conhecer significa simplificar. Ou seja, o método científico assenta-se na redução da complexidade. Para conhecer é necessário dividir, classificar e, depois, estabelecer as relações entre as partes.

O conhecimento científico é causal e aspira à formulação de leis, à luz de regularidades observadas, com vista a prever o comportamento futuro dos fenômenos. Isso pressupóe a ideia de ordem e de estabilidade do mundo, a ideia de que o passado se repete no futuro. $\mathrm{O}$ mundo é uma máquina, cujas operações podemos determinar, decompondo suas partes e estabelecendo relaçôes. O modelo newtoniano do mundo-máquina é a melhor imagem para sintetizar a grande hipótese universal da época moderna: o mecanicismo. 
Santos (1987: 17) observa: "O determinismo mecanicista é o horizonte certo de uma forma de conhecimento que se pretende utilitário e funcional, reconhecido menos pela sua capacidade de compreender profundamente o real do que pela capacidade de o dominar e transformar".

As disciplinas naturais forneceram aos homens da ciência, tradutores do domínio da Natureza, os instrumentos mais indicados e eficazes para tornar real essa apropriação. Luz destaca três elementos de síntese epistemológica comuns aos filósofos e cientistas: o modelo explicativo (mecanicista), o método (experimentalista e dedutivista) e a linguagem (matematizante). Sublinha que

esta síntese converteu-se em um dos traços básicos da racionalidade moderna, sendo um exemplo para a totalidade das disciplinas, ampliando-se posteriormente do campo racional da produção de verdades para outros domínios da ação e da criação humanas: para as técnicas (com a tecnologia), para o trabalho (com a ergonomia, a administração do trabalho), para as artes (com a institucionalização das Academias), para a moral e os costumes (com a ética e a política racionalista), e mesmo para certas instituiçôes do período clássico (asilos psiquiátricos, prisão, escolas, hospitais) que adotaram como ideal ortopédicosocial o modelo racionalista mecanicista. (Luz, 2004: 80-81)

Modelo, método e linguagem que caracterizam um regime de produção de verdade, no qual as suas regras de produção são mais importantes do que os objetos que investigam. A partir do século XVIII, o modelo de racionalidade científica se impôs como modelo global e totalitário. Apenas uma certeza, um dogma: o da ciência como caminho único para obtenção da verdade, para o processo de sua produção. Estrada única que nega o caráter racional de todas as formas de conhecimento que não se pautam pelos seus princípios epistemológicos e por suas regras metodológicas.

\section{RACIONALIDADE CIENTÍFICA MÉDICA}

A medicina científica moderna nasceu a partir de uma ruptura com as velhas concepções sobre o organismo humano. A arte de curar indivíduos doentes se transformou, gradativamente, em uma disciplina sobre as doenças. Acrescenta Luz (2004: 122), 
O sistema classificatório das morbidades, conduzido pelos médicos do Renascimento e da época clássica, busca seu modelo, em termos de observação (sistemática, ordenatória, empírica) e de modo de pensar as doenças (classificatório, agindo também por analogias e metáforas de similaridades) nas disciplinas da botânica e - depois - da história natural.

Esse modelo impõe compreender a doença como um fenômeno da Natureza: com suas espécies, características observáveis, curso e desenvolvimento. A doença é Natureza, mas uma natureza que exerce uma ação particular sobre um corpo individual. Os clínicos procuraram, no leito dos doentes ou no microscópio do século XVII, as evidências que apontavam para esta ou aquela doença.

Ao longo da época clássica, a prática clínica foi se transformando, com a reorganização dos hospitais como espaço clínico, em uma ciência das entidades patológicas.

Antes do século XVIII, a função essencial do hospital era prestar assistência aos pobres e, também, separá-los e excluí-los. O pobre doente era perigoso e o hospital deveria estar presente tanto para recolhê-lo, quanto para proteger os outros do perigo que ele encarnava. É um lugar de internamento, onde se justapunham e se misturavam não apenas doentes, mas igualmente loucos, meliantes, devassos, prostitutas etc. - uma espécie de instrumento misto de exclusão, assistência e transformação espiritual, em que a função médica não aparece. Como se fez essa reorganização do hospital? Para Foucault (1979), não foi com base em uma técnica médica que o hospital foi reordenado, porém, essencialmente, a partir de uma tecnologia que pode ser chamada política: a disciplina. Segundo ele:

A disciplina é o conjunto de técnicas pelas quais os sistemas de poder vão ter por alvo e resultado os indivíduos em sua singularidade. É o poder de individualização que tem o exame como instrumento fundamental. O exame é a vigilância permanente, classificatória, que permite distribuir os indivíduos, julgá-los, medilos, localizá-los e, por conseguinte, utilizá-los ao máximo. Através do exame, a individualidade torna-se um elemento pertinente para o exercício do poder. (Foucault, 1979: 107)

A introdução dos mecanismos disciplinares no espaço confuso do hospital permitiu sua medicalização. Essa disciplina tornou-se assunto e poder confiado ao médico, visto que também houve uma transformação no saber 
médico. A formação de uma medicina hospitalar deveu-se, por um lado, à disciplinarização do espaço hospitalar e, por outro, à transformação, no século XVIII, do saber e das práticas médicas.

Em O Nascimento da Clínica, Foucault (1987) realiza uma investigação arqueológica sobre a produção do conhecimento da medicina e sobre a transformação operada na estrutura de sua racionalidade e no domínio de sua experiência. Ele se contrapõe à explicação das histórias factuais da medicina, que atribuem a sua transformação em ciência empírica por uma evolução conceitual e epistemológica advinda de um refinamento que determinou mais precisamente os conceitos e noções, e da utilização de instrumentos que permitiram ver melhor o que não se enxergava. A medicina moderna nasceu de rupturas: "o conflito não é entre um saber jovem e velhas crenças, mas entre duas figuras de saber" (Foucault, 1987: 144).

Roberto Machado, analisando esse texto de Foucault, destaca que

a ruptura que inaugura a medicina moderna é o recorte de um novo domínio, é a demarcação de um novo espaço: a passagem de um espaço da representação, ideal, taxonômico, superficial, para um espaço objetivo, real, profundo. Mais explicitamente, a passagem de um espaço de configuração da doença, considerada como espécie nosográfica, para um espaço de localização da doença, o espaço corpóreo individual. (Machado, 1988: 98)

É o "olhar de superfície" de Bichat ${ }^{32}$ que transpôs o olhar médico do espaço ideal das categorias nosográficas da medicina classificatória para a espessura e o volume do espaço corporal da medicina anatomoclínica. Foucault (1987: 155) enfatiza:

Na experiência anátomo-clínica, o olho do médico deve ver o mal se expor e dispor diante dele à medida que penetra no corpo, avança por entre seus volumes, contorna ou levanta as massas e desce em sua profundidade. A doença não é mais um feixe de características disseminadas pela superfície do corpo e ligadas entre si por concomitâncias e sucessões estatísticas observáveis; é um conjunto de formas e deformações, figuras, acidentes, elementos deslocados, destruídos ou modificados que se encadeiam uns nos outros, segundo uma geografia que se pode seguir passo a passo. Não é mais uma espécie patológica inserindo-se no corpo, onde é possível; é o próprio corpo tornando-se doente.

${ }^{32}$ François Xavier Bichat lançou as bases da medicina clínica do século XIX. Aprofundando o conceito de Magnani, Bichat afirmou que a doença não deveria ser vista como lesões de um órgão, mas sim como lesões de tecidos específicos. 
O hospital se constituiu como o lócus para a produção de uma verdade objetiva sobre o corpo doente. $\mathrm{O}$ grande laboratório que possibilita um olhar que esquadrinha, observa, anota, cataloga, classifica e intervém. Por um lado, o corpo humano, sede das doenças, será aberto, dissecado, objeto do olhar que investigará os órgãos, os tecidos e os sistemas. Por outro, a patologia clínica produzirá uma gramática dos signos do corpo, um discurso sobre a doença. Essa incessante busca das 'causas' das relações entre o corpo e a doença, por meio da observação, descrição e classificação, constitui o objeto fundamental de conhecimento da medicina moderna. Nesse sentido, argumenta Luz (2004: 128): "O mais importante aqui, a questão epistemológica fundamental, é que a medicina, tornando-se uma ciência das doenças, vivendo da morte, transforma a questão da vida - e do homem vivo, embora doente - numa questão metafísica, portanto supérflua para o conhecimento".

Eis a grande contribuição da medicina para a racionalidade moderna: a disciplina das doenças. A doença e o corpo se constituem em positividades, em objetos do discurso científico moderno, através de categorias como entidade mórbida, corpo doente, organismo, fato patológico, lesão, sintoma etc. Por outro lado, excluíram-se, como questôes positivamente tematizáveis, a vida, a saúde, a cura. "A saúde passará a ser vista não como afirmação da vida, mas ausência de uma patologia. A "cura” será substituída pela cessação de sintomas, sobretudo dos sintomas principais, ou "chaves" de uma doença (Luz, 2004: 130).

É assim, da eliminação da doença no corpo dos indivíduos, que nasce a saúde na medicina moderna.

\section{RACIONALIDADE PSIQUIÁTRICA}

Foi no mesmo momento histórico, passagem do século XVII ao XVIII, que o hospital se organizou como instrumento e lócus médico, que a loucura ganhou estatuto de doença mental.

Para Foucault (1979), no período da Revolução Francesa, suprimiu-se o internamento, símbolo da opressão do Antigo Regime (Ancien Régime), como marco de um novo mundo. Porém, os loucos restituídos à liberdade podiam ser perigosos à sua família e ao seu grupo. Assim, as casas de 
internamento foram paulatinamente reservadas aos loucos, que se tornaram os herdeiros naturais do internamento e das medidas de exclusão.

O nascente mundo moderno liberal efetuou uma profunda ruptura com o mundo antigo. Na teoria política e na filosofia, autores como Hobbes, Locke e Rousseau referem-se a um novo homem emergindo em uma nova configuração política, econômica e social. Temas como direitos naturais, livre iniciativa, liberdade individual configuravam o projeto iluminista que buscava, por meio do conhecimento, libertar o homem dos grilhôes que lhe eram impostos pela ignorância e pela superstição. Os homens eram livres e dotados de uma racionalidade que lhes permitia conhecer o real e agir livremente.

A liberdade e a racionalidade constituíam o que é naturalmente próprio do homem. Todavia, e o louco? Segundo Foucault (1979), o louco é aquele que, por sua irresponsabilidade inocente, vem abolir a liberdade, comprometendo a razão. Assim, seu confinamento constituía-se em uma medida, por um lado, de caráter jurídico, retirando dele uma liberdade que por sua própria conduta ele já aboliu. Por outro, internar era organizar a liberdade. A loucura deveria ser conduzida à verdade, à razão, por meio do encontro com o médico, personagem a quem cabia levar o louco de volta à liberdade. Dessa forma, o internamento ganhou uma nova significação: tornou-se medida de caráter médico. A casa de internamento foi transformando seu espaço interno, além de segregação/isolamento, também, em tratamento. A loucura tornou-se objeto médico: ganhou valor de doença.

Os nomes de Pinel e Tuke estão associados à humanização dos métodos do tratamento. Contudo, não romperam com as antigas práticas de internamento: pelo contrário, eles as estreitaram em torno do louco. Tuke, na Inglaterra, montou um asilo que é a reconstituição em torno do alienado de uma 'quase família', onde ele deveria sentir-se em casa. Era submetido, por isso mesmo, a um controle social e moral ininterrupto: a cura significava inculcar-lhe sentimentos de dependência e humildade. Os métodos eram ameaças, castigos, privações alimentares, humilhaçôes, em resumo, tudo o que poderia, ao mesmo tempo, infantilizar e culpabilizar o louco. Pinel, depois de haver "libertado os acorrentados", reconstituiu em torno deles um encadeamento moral, que transformou o asilo em uma espécie de instância perpétua de julgamento: o louco era vigiado nos seus gestos, rebaixado nas suas pretensões; contradito no seu delírio, ridicularizado nos seus erros: a sanção tinha de seguir imediatamente qualquer desvio em relação a uma conduta normal. 
A doença mental tornou-se uma forma de erro ou de ilusão que se confrontava com certa normalidade de condutas. Uma desordem que se manifestava pelas maneiras de agir e sentir, pela vontade e liberdade do homem. O médico estava encarregado de efetuar mais um controle moral do que uma intervenção terapêutica. Ele era, no asilo, o agente das sínteses morais.

Foucault (1979: 122) apresenta uma função que o hospital psiquiátrico teve no século XIX:

lugar de diagnóstico e de classificação, retângulo botânico onde as espécies de doenças são divididas em compartimentos cuja disposição lembra uma vasta horta. Mas também espaço fechado para um confronto, lugar de uma disputa, campo institucional onde se trata de vitória e de submissão. O grande médico do asilo (...) é ao mesmo tempo aquele que pode dizer a verdade da doença pelo saber que dela tem, e aquele que pode produzir a doença em sua verdade e submetê-la, na realidade, pelo poder que sua vontade exerce sobre o próprio doente.

Por outro lado, em 1822, surgiu um modelo médico para a concepção da doença mental que abalou as teses do tratamento moral. Bayle, ${ }^{33}$ na mesma linha de trabalho iniciada por Bichat, caracterizou as lesões cerebrais na paralisia cerebral, denominando-as de "aracnite" e "meningite crônica", e relacionou as perturbaçôes morais dos pacientes com essas lesões. Birman (1978: 52) afirma:

Construiu assim a primeira enfermidade mental de acordo com a racionalidade médica. Esta era fundada na Anatomia patológica, que dava a razão última de ser para as manifestaçóes clínicas: as enfermidades seriam um conjunto de sintomas e sinais, sendo estes os fenômenos superficiais que expressavam uma lesão corporal. A doença estaria localizada no plano profundo do corpo, nos órgãos e tecidos alterados, mas manifestando-se por signos aparentes.

Os estudos de Bayle ofereceram o argumento anatomopatológico para um diagnóstico objetivo e para a conduta terapêutica, possibilitando também um modelo de investigação. Há que enumerar e descrever exaustivamente as manifestações exteriores, os sintomas, para caracterizar as diferentes patologias que, em última análise, são os desregramentos das funções cerebrais. Era a psiquiatria em busca de um corpo para sua doença.

${ }^{33}$ Seu nome completo era Antoine Laurent Jesse Bayle e sua tese de 1822 intitulou-se "Recherches sur l'Arachinite Chronique". 
A subjetividade se exterioriza, se torna uma verdade positiva, ou seja, uma realidade passível de observação científica. Este é o fundamento para toda uma 'ciência' baseada nas evidências dos sintomas e sinais: a psicopatologia. E, como objeto de conhecimento, a loucura só poderá ser abordada pelo médico, delegado da Razão. A experiência humana da loucura desapareceu. Em seu lugar, surge um discurso da racionalidade que define quem está privado dela. As correntes que aprisionam a loucura já não são feitas de ferro, mas, sobretudo, de palavras.

Chauí (1980: 2) nomeia isso como "discurso competente", que pode ser assim caracterizado: "não é qualquer um que pode dizer qualquer coisa a qualquer outro em qualquer ocasião e em qualquer lugar”. Há assuntos, momentos e pessoas adequados para o saber ser enunciado. Foucault (2004), partindo de uma questão semelhante sobre o discurso, aponta para três tipos de interdição que se cruzam, se reforçam e se compensam, como consequência desse tipo de enunciado: há um tabu do objeto, um ritual da circunstância e um direito privilegiado do sujeito que fala. Só algumas pessoas, em circunstâncias especiais, podem falar sobre determinados objetos.

Falar cientificamente sobre a subjetividade humana expressa nas emoções, afetos, percepções, pensamentos é falar de um campo marcado por uma racionalidade que exclui qualquer outra forma de saber que não se guie pelos cânones da ciência: objetividade expressa na utilização do método científico que produza evidências experimentais que demonstrem a determinação material da patologia mental.

O discurso psiquiátrico como discurso do especialista sobre a loucura não é apenas uma prática médica, é uma Razão Instrumental. Para Adorno e Horkheimer (1985), a Razão, sujeito abstrato da história individual e coletiva do homem, afirmado em Kant e Hegel, converteu-se em uma razão alienada. $\mathrm{O}$ ideal iluminista da razão como instrumento de libertação, como realização da autonomia e da autodeterminação do homem, fracassou. Desviou-se de seu objetivo emancipatório e tornou-se uma Razão Instrumental, que submete a Natureza ao seu controle totalitário e exerce uma dominação incondicional dos homens. Conforme Marcuse (1969), a ciência e a técnica são usadas para dominar a natureza e, com isso, acelerar a produção por meio da dinamização das forças produtivas. A mesma ciência é utilizada para dominar os homens, pois eles se subordinam cada vez mais ao processo produtivo acelerado pela ciência e tecnologia. Nesse sentido, tornaram-se, 
elas mesmas, forças produtivas a serviço do capital, contribuindo para a manutenção das relações sociais. Afirma o autor que "talvez o próprio conceito de ciência e tecnologia seja ideologia" (Marcuse, 1969: 127). Habermas (1980) radicaliza essa tese, afirmando que ciência e técnica efetivamente se transformaram em ideologia, quer dizer, ambas passaram a ser a base de legitimação indispensável do moderno Estado capitalista.

Nessa perspectiva, afirmamos que a psiquiatria é o discurso que instrumentaliza e legitima uma intervenção política, uma prática disciplinadora, mediadora da sutil violência repressiva que caracteriza as sociedades contemporâneas. Após a Segunda Guerra Mundial, a psiquiatria vai deixar as grandes anomalias e voltar-se para a 'saúde mental', para a prevenção dos desvios. Não se trata mais de corrigir, mas de educar para produzir um indivíduo saudável e de prever a doença, antecipando-se onde houver comportamentos de risco, desviantes de norma. As reformas propostas pela psiquiatria comunitária norte-americana e pela psiquiatria de setor francesa concretizam esse ideal, como pode ser visto em Birman e Costa (1994), Amarante (1998) e Fleming (1976).

Com um afã de domínio e controle, a psiquiatria sempre buscou afirmar-se como um conhecimento científico, aplicando o modelo da racionalidade moderna ao funcionamento do psiquismo. Porém, sempre encontrou grandes dificuldades em se constituir como uma especialidade com um saber advindo da racionalidade médica. Birman (2001: 180-181) escreve: "O discurso da anatomoclínica, base epistemológica da dita medicina científica, não encontrava legitimidade no campo da psiquiatria. A psiquiatria buscava as causas físicas dos distúrbios mentais e apenas encontrava, desde Pinel e Esquirol, as causas morais".

As descobertas da psicofarmacologia, nos anos 50 do século $\mathrm{XX}$, e, sobretudo, nos anos 80 e 90, com o desenvolvimento das neurociências, renovaram as aspiraçóes da psiquiatria em conquistar seu status de ciência. Nessa pretensão, segue o modelo global e totalitário da racionalidade científica, negando e/ou invalidando toda forma de conhecimento sobre o psiquismo que não se guia pelos princípios epistemológicos e por suas regras metodológicas. Assim, as classificações adotadas oficialmente, como o Manual de Diagnóstico e Estatística das Perturbações Mentais, $4^{a}$ edição (DSM-IV), da Associação Psiquiátrica Americana, e o Código Internacional de Doenças, 10a edição (CID-10), da OMS, reproduzem um esforço para 
unificar de forma totalizadora os diagnósticos das doenças mentais. Pretendem que discurso, diagnóstico, raciocínio, método e terapêutica sejam claramente explicitados, baseados em evidência experimental e sustentados pela determinação consensual dos termos a serem usados, os quais representam, para seus formuladores, a tentativa de recuperar a identidade médica da psicopatologia e centrar-se em um sentido claro de ciência. Trata-se de uma classificação consensual que, com o apoio logístico e financeiro dos grandes laboratórios farmacêuticos, deve ser adotada em pacote, método e linguagem, por todos aqueles que, no mundo todo, pretendam praticar a 'boa psiquiatria'. Consensual e excludente, pois não há outra possibilidade de se pensar critérios diagnósticos.

A potencial descoberta e domínio dos processos cerebrais, responsáveis pelos diferentes estados da psique, reduzem o funcionamento psíquico a esses processos e são totalmente explicáveis em uma linguagem neurobioquímica. Assim, por exemplo, a depressão, nomeada por esse modelo de racionalidade como transtorno depressivo, é entendida como uma alteração do estado de humor produzida por uma disfunção na captação da serotonina no nível sináptico, cuja terapêutica adequada é a ingestão de uma classe específica de medicamento. Embora possa haver fatores externos intervenientes, serão sempre secundários e a 'boa conduta médica' indica uma primazia do tratamento psicofarmacológico. Segue-se, aqui, um dos princípios fundamentais da racionalidade científica moderna: simplificar para conhecer. A vida humana é por demais complexa, repleta de nuances, contradições e paradoxos. A tristeza que ela nos causa não pode ser compreendida se todos esses aspectos forem levados em consideração. Portanto, para essa racionalidade, o homem é uma máquina que deve possuir um funcionamento padrão ótimo, e tudo aquilo que se desviar desse padrão/normalidade deve sofrer uma intervenção para readequá-lo, readaptá-lo, corrigi-lo. A depressão é recortada da 'sujeira' da vida cotidiana, isolada e estudada naquilo que de fato conta para esse tipo de ciência: seus processos bioquímicos.

Como ser infeliz em uma sociedade industrial moderna que tudo possibilita? Há um ideal de felicidade contemporânea que pode e deve ser adquirido em pílulas. O sujeito não pode querer 'ficar de fora'. De acordo com Birman (2001: 191): "Na cultura da exaltação desmesurada do eu, não existe mais lugar para os deprimidos e os panicados. Estes são execrados, lançados no limbo da cena social, já que representam a impossibilidade de serem cidadãos da sociedade do espetáculo". 
Esse autor ressalta que as culturas do narcisismo e do espetáculo, ${ }^{34}$ marcantes em nosso tempo, construíram um modelo de subjetividade em que se silenciam as possibilidades de reinvenção do sujeito e do mundo, impondo ideais e padróes de comportamento totalitários e totalizantes. A psiquiatria, a psicologia, as ciências humanas, de maneira geral, como saber e conhecimento científico e racional sobre o humano, instrumentalizam e legitimam esses ideais e padrões, inseridos em uma lógica de mercado, em que não importa ser, mas consumir. Acena-se com promessas de rápida e imediata satisfação. Mesmo a 'peste' da psicanálise, a que um dia Freud acreditou estar levando a sociedade norte-americana, rendeu-se, ao menos em parte de sua comunidade, a essa lógica, neutralizando o seu potencial crítico e se transformando em uma prática homogeneizadora de subjetividades. Em outro texto, Birman (2005: 221) critica uma parcela da comunidade psicanalítica que, na atualidade, busca construir uma versão tecnológica da psicanálise, por meio da "bricolagem entre o discurso psicanalítico, as neurociências e o cognitivismo", almejando e prometendo o apaziguamento, a cura para os conflitos da existência.

Contudo, a busca solitária e desesperada permanece. A incômoda sensação de desamparo, de desassossego, insiste. $\mathrm{O}$ mal-estar resiste.

Não pretendo aqui menosprezar ou negar que a sociedade contemporânea deve muito aos avanços da ciência moderna, mas afirmar que esta mesma ciência atravessa hoje uma profunda crise e fracassou em suas promessas de progresso e de felicidade, transformando-se em ameaças de destruição. Santos (2001: 56) diz que

a promessa da dominação da natureza, e do seu uso para o benefício comum da humanidade, conduziu a uma exploração excessiva e despreocupada dos recursos naturais, à catástrofe ecológica, à ameaça nuclear, à destruição da camada de ozônio, e à emergência da biotecnologia, da engenharia genética e da conseqüente conversão do corpo humano em mercadoria última. A promessa de uma paz perpétua, baseada no comércio, na racionalização científica dos processos de decisão e das instituições, levou ao desenvolvimento tecnológico da guerra e ao aumento sem precedentes de seu poder destrutivo. A promessa de uma sociedade mais justa e livre, assente na criação da riqueza tornada possível pela conversão da ciência em força produtiva, conduziu a espoliação do chamado Terceiro Mundo e a um abismo cada vez maior entre Norte e o Sul. Neste século morreu

\footnotetext{
${ }^{34}$ Referência aos trabalhos de Lasch (1983) e Debord (1997), que, para Birman, são instrumentos teóricos agudos para realizar uma leitura das novas formas de subjetivação na atualidade.
} 
mais gente de fome do que em qualquer dos séculos anteriores, e mesmo nos países mais desenvolvidos continua a subir a percentagem dos socialmente excluídos, aqueles que vivem abaixo no nível de pobreza.

\section{CRISE DO PARADIGMA CIENTÍFICO DA MODERNIDADE}

Santos (1987) aponta para um interessante paradoxo: a identificação dos limites e das insuficiências estruturais do paradigma científico dominante só foi possível graças ao grande avanço que ele mesmo propiciou. Isso leva a ciência moderna a uma crise que, desde o início do século $\mathrm{XX}$, vem causando abalos profundos nos fundamentos que sustentam o discurso e as verdades produzidas por ela.

Esse autor vai buscar nas ciências naturais e na matemática, que alicerçam o modelo da racionalidade científica moderna, quatro condições teóricas da crise do paradigma dominante: a primeira é dada pela "teoria sobre a relatividade da simultaneidade" de Einstein, a qual estabelece uma distinção entre a simultaneidade de acontecimentos presentes no mesmo lugar e os acontecimentos separados por distâncias astronômicas. Ou seja, dois acontecimentos simultâneos em um sistema de referência não são simultâneos noutro sistema. Como exemplo, podemos citar o "paradoxo dos gêmeos". Um dos gêmeos parte em uma viagem espacial a uma velocidade próxima da luz, enquanto seu irmão permanece na Terra. Ao retornar do espaço, por causa de seu movimento, o gêmeo viajante descobrirá, vendo seu irmão mais envelhecido, que o tempo fluiu mais lentamente na espaçonave. Essa teoria revoluciona as concepções newtonianas de tempo e espaço absolutos.

A segunda condição teórica da crise é apresentada pela física quântica. Os estudos de Heisenberg e Bohr operam um profundo questionamento na noção de neutralidade e na separação entre o sujeito e o objeto do conhecimento, ao demonstrar que, no nível quântico, não é possível observar ou medir um objeto sem interferir nele, sem o alterar, e a tal ponto que a simples medição de um objeto o modifica. Do real só conhecemos aquilo que é nosso, quer dizer, a nossa intervenção sobre ele. Heisenberg postula, em seu "princípio da incerteza", que, quando conhecemos perfeitamente as propriedades geométricas de um átomo, não conseguimos conhecer suas propriedades físicas dinâmicas e vice-versa, sendo impossível determinar o 
estado passado e futuro do fenômeno estudado, isto é, suas causas e efeitos. Em todo fenômeno há incerteza e indeterminação.

Disso decorrem as seguintes importantes consequências: o nosso conhecimento está estruturalmente limitado e só podemos aspirar a resultados aproximados. Com isso, o determinismo mecanicista torna-se relativo porque a soma das partes em que dividimos o real, para melhor medir e observar, não corresponde à sua totalidade. Por fim, a separação entre sujeito/ objeto é muito mais complexa do que se supunha, ou seja, não há separação, pelo contrário, há um continuum.

A terceira condição refere-se ao principal instrumento da racionalidade científica moderna: o rigor da matemática. Santos (2001: 70) recorre ao "teorema da incompletude" de Gödel, o qual demonstra que, "mesmo seguindo à risca as regras da lógica matemática, é possível formular proposições indecidíveis, proposiçôes que se não podem demonstrar nem refutar". Quer dizer, em qualquer proposição axiomática consistente, baseada em aritmética, existem sentenças sobre as quais não é possível decidir se são verdadeiras ou falsas. Por exemplo, em um jogo criado a partir da aplicação perfeitamente lógica de um conjunto fixo de regras, surgirão lances que não podem ser julgados como válidos ou faltosos, de acordo com as suas próprias regras. Estamos frente a frente com um paradoxo. Isso significa que nenhum sistema lógico se basta a si mesmo, nem é capaz de compreender-se sozinho a si mesmo: sempre será necessário um sistema maior e mais complexo para dar conta de tudo que o sistema menor contém. Portanto, existem sentenças aritméticas, formuláveis em uma determinada axiomática baseada em aritmética, que não podem ser provadas ou refutadas.

Kubrusly (2005) apresenta uma situação que permite ilustrar esse paradoxo. Ele conta uma história sobre um barbeiro, em Sevilha, que mandou pendurar na porta de sua casa uma tabuleta com os seguintes dizeres: "Faço a barba de todos que não fazem a própria barba, e somente deles". A pergunta que se pode fazer é: quem faz a barba do barbeiro? Nota-se, primeiramente, que não há barbudos na cidade, pois todos que não fazem a própria barba, a terão feita pelo barbeiro. Logo, o barbeiro faz a própria barba se, e somente se, não fizer a própria barba. A afirmação: "O barbeiro faz a sua própria barba" é verdadeira se, e somente se, for falsa e vice-versa.

Para Santos, ao relativizar o rigor da matemática, estes estudos questionam a afirmação de Galileu de que "o grande livro da natureza está escrito 
em caracteres matemáticos", sintetizando o pensamento da racionalidade científica moderna que encontra o rigor de suas formulações na matemática. Os trabalhos de Gödel demonstram que "o rigor da matemática carece, ele próprio, de fundamento" (Santos, 2001: 70), o que, como consequência, abala a confiabilidade desta racionalidade que se sustenta na frieza e na lógica, até então, inabalável dos cálculos.

A quarta condição é constituída pelos avanços do conhecimento nos domínios da microfísica, da química e da biologia, nos últimos trinta anos, especialmente, a "teoria das estruturas dissipativas" do físico-químico Ilya Prigogine, o qual rompe com o mundo mecânico e determinista, introduzindo uma dimensão totalmente nova do tempo. Sua tese é a de que os processos químicos (da vida) são irreversíveis e dependentes do tempo e compõem o que denomina de estruturas dissipativas - estruturas caóticas, mas que não necessariamente conduzem à desordem. Esses processos irreversíveis são fontes de "novas ordens", que - associadas ao seu caráter randômico e de troca com o meio - levam a níveis mais elevados de organização: "Ordem e desordem mostram-se aqui não como opostos entre si, e sim indissociáveis" (Prigogine \& Stengers, 1992: 54).

A irreversibilidade nos sistemas abertos, ou seja, a quebra de simetria entre um antes e um depois, a noção de acontecimento como fruto de possibilidades, e não de determinação, introduzem a história nos processos físico-químicos. Santos (2001: 70-71) relata:

Em vez da eternidade, a história; em vez do determinismo, a imprevisibilidade; em vez do mecanicismo, a interpenetração, a espontaneidade e a auto-organização; em vez da reversibilidade, a irreversibilidade e a evolução; em vez da ordem, a desordem; em vez da necessidade, a criatividade e $\mathrm{o}$ acidente.

Tempo e espaços como não absolutos, interferência do observador no fenômeno, relativização do rigor matemático e auto-organização criativa dos sistemas. $\mathrm{O}$ antigo/moderno mundo estático e sujeito às leis imutáveis e deterministas vai sendo substituído pela visão de um universo instável e dinâmico, reino da incerteza, do acaso e da criatividade.

A esta análise podemos acrescentar a "ferida narcísica" proporcionada pela psicanálise. Em seu artigo "Uma dificuldade no caminho da psicanálise", de 1917, Freud (1980a) conta como o narcisismo universal dos homens sofreu três severos golpes: o primeiro foi dado por Copérnico, que destruiu a ilusão 
de que o domicílio do homem, a Terra, era o centro do universo, com o sol, a lua e os planetas girando ao seu redor, o que o tornava senhor do mundo; o segundo foi provocado por Charles Darwin, ao provar que o homem possui uma ascendência animal, não sendo um ser diferente dos outros animais ou superior a eles; e o terceiro golpe foi contra o amor próprio do homem. Um golpe psicológico desferido pelo próprio Freud, ao afirmar que o ego não é o senhor da sua própria casa, pois as nossas pulsões sexuais não podem ser inteiramente domadas, os nossos processos mentais são inconscientes e somente atingem o ego e a ele se submetem por meio de percepções incompletas e de pouca confiança. A consciência não é a essência da vida psíquica, mas apenas uma de suas qualidades. Com isso, o projeto iluminista que colocava a Razão como senhora absoluta do destino da vida e dos desejos do homem sofreu um forte abalo.

Para Freud, há um mais além (e aquém, acima e abaixo) do princípio da razão. Existe o mistério do inconsciente. No lugar do homem racional poderoso e autônomo frente à natureza, temos um sujeito dividido entre a consciência e o inconsciente; temos a incompletude do humano com sua falta inaugural e estruturante, que o lança na aventura da vida como ser desejante; temos o "desamparo" frente aos dilemas da existência.

Vale aqui salientar que Freud nem sempre foi um crítico da razão iluminista. Birman (2005) aponta para os textos freudianos iniciais, em que é evidente sua crença no poder do discurso científico, para promover o "progresso do espírito humano", e do papel que a psicanálise poderia desempenhar, proporcionando a cura das perturbações do espírito e do desamparo humano. Como prova dessa afirmação, Birman cita o texto de 1908, Moral Sexual "Civilizada" e a Doença Nervosa Moderna, no qual Freud (1980c) vislumbra a possibilidade de uma harmonia entre o registro da pulsão e o da civilização.

É a partir de 1915, especialmente com a segunda teoria das pulsões, enunciando o conceito de pulsão de morte, que a crença freudiana nessa harmonia cai por terra. Birman (2005: 213) ressalta:

Com efeito, pela mediação desse novo conceito de pulsão torna-se impossível a concepção de uma harmonia entre o registro da pulsão e o da civilização. Pelo viés da pulsão de morte, concebida agora como silenciosa e não inscrita originariamente no campo da representação, a harmonia com o registro da civilização não se torna mais possível. Portanto, no que tange à espécie humana, a vida seria 
algo a ser conquistado, um vir-a-ser e um destino possível, mas não um valor instituído de maneira originária.

É em Mal-Estar na Civilização, texto de 1930, que Freud demonstra sua descrença na ideia do progresso do espírito humano mediado pelo logos científico, como pode ser visto no trecho a seguir:

Ficamos inclinados a dizer que a intenção de que o homem seja feliz não se acha incluída no plano da Criação (...) nossas possibilidades de felicidade sempre estão restringidas por nossa própria constituição. Já a infelicidade é muito menos difícil de experimentar. O sofrimento nos ameaça a partir de três direçôes: de nosso próprio corpo, condenado à decadência e à dissolução (...); do mundo externo, que pode voltar-se contra nós com forças de destruição; e, finalmente, de nossos relacionamentos com os outros homens. (Freud, 1980b: 95)

E no mesmo texto, mais à frente, Freud (1980b: 102-103) afirma:

O programa de tornar-se feliz, que o princípio do prazer nos impõe, não pode ser realizado; contudo, não devemos - na verdade, não podemos - abandonar nossos esforços de aproximá-lo da consecução, de uma maneira ou de outra. Caminhos muito diferentes podem ser tomados nessa direção, e podemos conceder prioridades quer ao aspecto positivo do objetivo, obter prazer, quer ao negativo, evitar o desprazer. Nenhum desses caminhos nos leva a tudo o que desejamos. A felicidade, no reduzido sentido em que a reconhecemos como possível, constitui um problema da economia da libido do indivíduo. Não existe uma regra de ouro que se aplique a todos: todo homem tem de descobrir por si mesmo de que modo específico ele pode ser salvo.

Há uma dimensão trágica do existir humano. Nosso desamparo diante do mundo coloca a cada homem o desafio de inventar, criar seu próprio caminho. E, para a psicanálise, isso implica uma ética com consequências políticas. Contudo, uma parte da comunidade psicanalítica, conforme mencionei anteriormente, na crítica formulada por Birman (2005), abandonou essa perspectiva, optando por buscar uma articulação com as neurociências e a psicofarmacologia, com promessas de harmonia e de apaziguamento das angústias existenciais, da dor de viver.

A grande contribuição da psicanálise está justamente em apresentar o humano com uma dimensão não racional, inconsciente, marcado por uma falta inaugural que o produz como sujeito desejante, que se aventura pela 
vida, carecendo do Outro para produzir e reproduzir permanentemente sua subjetividade. E é esse sujeito que também produz ciência.

Somando-se à crise dos fundamentos que sustentam o discurso e as verdades produzidas pela ciência moderna, emerge a dimensão subjetiva, com as trajetórias coletivas e pessoais dos sujeitos. $\mathrm{O}$ mito de uma ciência neutra, objetiva, vai-se desfazendo, sobretudo quando se coloca em cena a subjetividade neste mundo frio dos cálculos e das experimentações. Surgem então as vaidades, as disputas, os interesses econômicos e políticos que influenciam e são decisivos na definição das prioridades e dos investimentos.

E, nessa ciência em crise, há uma mudança nas bases epistemológicas do paradigma científico se configurando. Como afirma Santos (2001), estamos em um momento de transição paradigmática.

\section{COMPLEXIDADE E O PARADIGMA EMERGENTE}

É a partir dos dilemas colocados à ciência pela física de Einstein, pela geometria não euclidiana, pelo princípio da incerteza de Heisenberg, que Gaston Bachelard propóe uma nova epistemologia, rejeitando a doutrina das naturezas simples e absolutas, apontando para uma complexidade essencial da filosofia científica. "A ciência cria, com efeito, filosofia" (Bachelard, 2000: 12). Pretende mostrar que a ciência contemporânea obrigou-nos a renunciar à pretensão de um saber universal. Vê o filósofo retomando o projeto de compreender a relação do homem com o seu saber.

Bachelard foi filósofo, historiador das ciências, físico, químico e epistemólogo. Hilton Japiassu (1976a: 21) caracteriza sua obra como de uma dupla vertente: uma científica, a outra poética. Ao longo de sua vida, sentiu-se atraído pelo encanto do imaginário poético e passou "a estudá-lo e a valorizá-lo como uma das formas possíveis, não somente de se apreender, mas de se recriar a realidade". Como espistemólogo, propôs um racionalismo 'aberto', uma razão continuamente reformulada pelo próprio progresso do saber científico. Para ele, a ciência é histórica. Sua noção de progresso científico está ligada à descontinuidade, faz-se por rupturas com o senso comum. Japiassu (1976a: 23) enfatiza alguns aspectos em Bachelard: "A ciência, como o homem, não é criação da necessidade, porém do desejo. Por outro lado, é intervencionista. Por isto deve ser feita em uma comunidade de pesquisas e de críticas para não se tornar totalitária”. 
O conceito que sustenta o projeto de Bachelard é o de obstáculo epistemológico:

Quando se procuram as condições psicológicas do progresso da ciência, logo se chega à convicção de que é em termos de obstáculos que o problema do conhecimento científico deve ser colocado. E não se trata de considerar os obstáculos externos, como a complexidade e a fugacidade dos fenômenos, nem de incriminar a fraqueza dos sentidos e do espírito humano. É no âmago do próprio ato de conhecer que aparecem, por uma espécie de imperativo funcional, lentidões e conflitos. É aí que aparecem causas de estagnação e até de regressão, causas de inércia às quais chamamos de obstáculos epistemológicos. No fundo, o ato de conhecer dá-se contra um conhecimento anterior, destruindo conhecimentos mal estabelecidos, superando o que, no próprio espírito, é obstáculo à espiritualização (...) Quando o espírito se apresenta à cultura científica, nunca é jovem. Aliás, é bem velho, porque tem a idade de seus preconceitos. Aceder à ciência é rejuvenescer espiritualmente, é aceitar uma brusca mutação que contradiz o passado. (Bachelard, 1967: 14-15)

Um outro pensador crítico da ciência, Edgar Morin, observa, no 'projeto’ de Bachelard, um conceito pouco trabalhado por ele, porém essencial: a noção de complexidade. Para Morin, o problema da complexidade se tornou uma exigência social e política para o pensamento contemporâneo. A noção de complexidade pode ser entendida como um tecido interdependente, interativo e inter-retroativo entre o objeto do conhecimento e seu contexto, as partes, o todo e as partes entre si. União entre unidade e a multiplicidade.

Por exemplo, se tentamos pensar no fato de que somos seres ao mesmo tempo físicos, biológicos, sociais, culturais, psíquicos e espirituais, é evidente que a complexidade é aquilo que tenta conceber a articulação, a identidade e a diferença de todos esses aspectos, enquanto o pensamento simplificante separa esses diferentes aspectos, ou unifica-os por uma redução mutilante. Portanto, neste sentido, é evidente que a ambição da complexidade é prestar contas das articulaçôes despedaçadas pelos cortes entre as disciplinas, entre categorias cognitivas e entre tipos de conhecimento. (Morin, 2002: 176)

A aspiração a um conhecimento multidimensional poderia aparentar uma formulação de uma totalização unificante e universalizadora. Morin nos alerta para o fato de que essa multidimensionalidade comporta o princípio da incompletude e da incerteza. Ou seja, a complexidade surge como dificuldade, incerteza e não como clareza, como resposta. É, fundamentalmente, o 
desafio de incorporar a desordem, a contradição, a incerteza, o acaso, enfim, todos esses resíduos descartáveis considerados não científicos, na problemática geral do conhecimento científico. Com efeito,

o pensamento complexo é (...) essencialmente o pensamento que lida com a incerteza e que é capaz de conceber a organização. Trata-se de um pensamento capaz de reunir, contextualizar, globalizar, mas ao mesmo tempo de reconhecer o singular, o individual, o concreto. $O$ pensamento complexo não se reduz nem à ciência, nem à filosofia, mas permite uma comunicação mútua, fazendo o intercâmbio entre uma e outra. (Morin, 2003: 77)

É pensando no desafio proposto pela ciência da complexidade, que Prigogine e Stengers (1997) propóem a tese de que o que é válido para a complexidade químico-física é também válido, ou pelo menos útil, para a complexidade que é objeto de estudo das ciências humanas - a sociologia, a história, a filosofia. O título do livro no qual apresentam essa tese resume essa nova possibilidade de confronto e de síntese entre as ciências exatas e as ciências humanas: uma "nova aliança" - entre homem e natureza e entre ciência e filosofia.

Em outro texto, com o sugestivo nome de O Fim das Certezas, Prigogine (1996) afirma:

Assistimos ao surgimento de uma ciência que não mais se limita a situações simplificadas, idealizadas, mas nos põe diante da complexidade do mundo real, uma ciência que permite que se viva a criatividade humana como a expressão singular de um traço fundamental comum a todos os níveis da natureza.

A Natureza se faz e refaz constantemente. Colocar em cena a criatividade nos remete a pensar na arte, que potencializa ao máximo a capacidade de invenção, de nos oferecer novas perspectivas, ainda não pensadas. Trata-se de uma criação que nasce de um incessante ir e vir entre a ordem, o caos e a complexidade. Guattari (1992) nomeia essa concepção de caosmose, para marcar uma relação de osmose ou de imanência entre o caos e a complexidade. Para se pensar essa potencialidade criadora, propõe também um novo paradigma estético, alertando:

O novo paradigma estético tem implicaçōes ético-políticas porque quem fala em criação, fala em responsabilidade da instância criadora em relação à coisa criada, em inflexão de estado de coisas, em bifurcação para além de esquemas 
preestabelecidos (...). Mas essa escolha ética não mais emana de uma enunciação transcendente (...). A própria gênese da enunciação encontra-se tomada pelo movimento de criação processual. Isto é bem nítido no caso da enunciação científica, que tem sempre uma cabeça múltipla: a cabeça individual, é claro, mas também cabeça coletiva, cabeça institucional, cabeça maquínica com os dispositivos experimentais, a informática com os bancos de dados e a inteligência artificial... (Guattari, 1992: 137)

A Reforma Psiquiátrica se caracteriza por uma ruptura em relação à racionalidade psiquiátrica, ao recusar-se a aceitar o sofrimento humano apenas como o objeto simples da doença mental, mas por considerá-lo em sua complexidade. É do diálogo entre as diferentes e diversas disciplinas que cuidam desse sofrimento que se cria uma nova maneira de olhar, de escutar, de cuidar. Para Rotelli, Leonardi e Mauri (2001), se o objeto não é mais simples (a doença), a tarefa é criar, inventar instituiçôes, as quais devem se renovar a cada novo encontro com os usuários, pois cada história de vida nos apresenta a complexidade da vida. Novamente recorremos a Riobaldo, personagem do livro Grande Sertão: veredas, de Guimarães Rosa (1985: 21), que sintetiza o que podemos pensar ser a meta mais radical de uma instituição inventada: "o mais importante e bonito, do mundo, é isto: que as pessoas não estão sempre iguais, ainda não foram terminadas - mas que elas vão sempre mudando. Afinam ou desafinam".

As palavras 'incerteza', 'desafios', 'riscos', 'curiosidade' estão sempre presentes ao se falar em complexidade. Essas mesmas palavras definem bem o sentimento daquele que busca compreender a aventura chamada loucura. Colocam-nos em movimento, na busca de construir pontes que nos levem à possibilidade de um diálogo com essa 'complexa vivência humana'.

Boaventura Souza Santos é outro autor que aponta para um período de transição de paradigma. Por ser uma transição, só podemos vislumbrar sinais de um novo conhecimento constituído pelo que ele chama de "paradigma de um conhecimento prudente para uma vida decente". Afirma a atual revolução científica como estruturalmente diferente daquela do século XVI, que marcou o nascimento da ciência moderna:

Sendo uma revolução científica que ocorre numa sociedade ela própria revolucionada pela ciência, o paradigma a emergir dela não pode ser apenas um paradigma científico (o paradigma de um conhecimento prudente), tem e ser também um paradigma social (o paradigma de uma vida decente). (Santos, 1987: 37) 
Para ele, o conhecimento produzido por esse novo paradigma deve apresentar as seguintes características:

- Todo conhecimento científico-natural é científico-social.

As contribuições da física e da biologia, já destacadas anteriormente, como os conceitos de auto-organização ou a teoria das estruturas dissipativas de Prigogine, introduzem na matéria os conceitos antes exclusivos da ordem do humano, como historicidade e autonomia, superando a distinção decretada no século XVI, entre o Homem e a Natureza. Santos (1987: 38) argumenta: "É como se o homem e a mulher se tivessem lançado na aventura de conhecer os objetos mais distantes e diferentes de si próprios, para, uma vez aí chegados, se descobrirem refletidos como num espelho".

Como exemplo, apresento as cenas finais do filme 2001: uma odisseia no espaço, de Stanley Kubrick, que podem ilustrar esse encontro. Depois de haver derrotado o supercomputador e após uma longa jornada, mergulhado em uma velocidade que sugere a da luz, o último astronauta chega a um ambiente futurista e encontra a si mesmo. Rapidamente o tempo passa e a cada corte de cena, ele envelhece, até o momento em que, em seu leito de morte, vislumbra a enigmática pedra negra e vê a si próprio como um feto, um porvir humano pleno de possibilidade, flutuando no espaço.

Santos (1987: 39-40) acrescenta:

O conhecimento do paradigma emergente tende assim a ser um conhecimento não dualista, um conhecimento que se funda na superação das distinçôes tão familiares e óbvias que até há pouco considerávamos insubstituíveis, tais como natureza/cultura, natural/artificial, vivo/inanimado, mente/matéria, observador/ observado, subjetivo/objetivo, coletivo/individual, animal/pessoa.

A superação da dicotomia ciências naturais/ciências sociais tende a revalorizar os estudos humanísticos. Assim, essa superação coloca a concepção humanística das ciências sociais como agente catalisador e a pessoa, enquanto autor e sujeito do mundo, no centro do conhecimento, todavia, ao contrário das humanidades tradicionais, dispóe o que hoje designamos por natureza no centro da pessoa. "Não há natureza humana porque toda a natureza é humana” (Santos, 1987: 44).

Vale ressaltar aqui que o processo da Reforma Psiquiátrica alinha-se com essa perspectiva, ao propor a desconstrução dos paradigmas fundantes 
da psiquiatria, que, sob a égide do racionalismo científico moderno, operam uma simplificação e estabelecem dicotomias entre saúde/doença e normal/patológico. Não há explicação baseada na causalidade biológica, capaz de dar conta da complexidade do existir e do sofrer humano. A ruptura epistemológica da Reforma Psiquiátrica propõe que o homem, e não a bioquímica dos neurotransmissores, esteja no centro.

- Todo conhecimento é local e total.

Uma das marcas mais evidentes da ciência moderna é a especialização. O conhecimento avança por ela e será tanto mais rigoroso quanto mais restrito seu objeto. Quanto a isso, Santos (1987: 46) ressalta:

Sendo um conhecimento disciplinar, tende a ser um conhecimento disciplinado, isto é, segrega uma organização do saber orientada para policiar as fronteiras entre as disciplinas e reprimir os que as quiserem transpor. É hoje reconhecido que a excessiva parcelização e disciplinarização do saber científico faz do cientista um ignorante especializado.

Já no paradigma emergente, o conhecimento é total e também local, pois se constitui ao redor de temas que,

em um dado momento são adotados por grupos sociais concretos como projetos de vida locais, sejam eles reconstituir a história de um lugar, manter um espaço verde, construir um computador adequado às necessidades locais, fazer baixar a taxa de mortalidade infantil, inventar um novo instrumento musical, erradicar uma doença, etc., etc. (Santos, 1987: 47-48)

A busca do conhecimento total nos leva não apenas a transpor as rígidas fronteiras entre as disciplinas, mas a reconstruí-las em uma perspectiva que supera os campos disciplinares, estabelecendo um constante diálogo transdisciplinar.

Novamente aqui temos uma grande aproximação com a Reforma Psiquiátrica. Ao romper com a visão biológica reducionista e produzir uma desmontagem dos conceitos basilares da psiquiatria, ela propõe construir/ tecer/inventar o seu campo teórico-conceitual, estabelecendo um amplo, profundo e radical diálogo entre as diferentes disciplinas e conhecimentos que tratam do humano.

Outro conceito-chave proposto pela Reforma Psiquiátrica e que constrói uma identidade com o proposto por esse paradigma emergente é o do 
território, que nos remete ao conceito do conhecimento local. Território é aqui entendido não apenas como a configuração de um espaço geográfico, mas refere-se às forças vivas de uma dada comunidade, com sua cultura, seus problemas, suas prioridades e potencialidades locais. O espaço, sobre o qual a ação da Reforma Psiquiátrica vai incidir, está intrinsecamente ligado a esse conceito. Um serviço substitutivo deve necessariamente ser pensado como um dispositivo que tece (no sentido de trabalhar a urdidura e a trama) e ativa uma rede de cuidados.

- Todo conhecimento é autoconhecimento.

A ciência moderna consagrou o homem enquanto sujeito epistêmico, mas expulsou-o, tal como a Deus, enquanto sujeito empírico. Um conhecimento objetivo, factual e rigoroso não tolerava a interferência dos valores humanos e religiosos. Foi nesta base que se construiu a distinção dicotômica sujeito/objeto. (Santos, 1987: 48)

Para as ciências humanas, essa distinção nunca foi pacífica, porque seus objetos de estudos eram homens e mulheres, tais como os pesquisadores que se propunham estudá-los. Para contemplar a distância epistemológica entre sujeito e objeto, criou-se uma distância empírica entre eles.

No paradigma emergente, assume-se a implicação do sujeito no processo de produção de conhecimento, tendo um caráter autobiográfico e autorreferenciável. Caracteriza-se como um conhecimento compreensivo e íntimo, que nos une pessoalmente ao que estudamos, aproximando a criação científica da criação literária ou artística. Temos assim uma ciência autoral que cria um conhecimento que nos ensina a viver e traduz-se num saber prático.

O campo da Reforma Psiquiátrica trata essencialmente do humano. Produzir uma radical ruptura com a dicotomia sujeito/objeto nos lança frente a frente com a complexidade do existir, com a dor em suas múltiplas dimensões, com nossos próprios limites e potencialidades como atores e agentes do cuidado e da produção de conhecimento. Não há como fazer do sujeito um objeto sem deixar de conhecê-lo como sujeito e sem considerar que aquele que olha está implicado nesse encontro.

Nesse sentido, somos todos um pouco autores de múltiplas narrativas dos encontros possíveis e impossíveis, buscando construir um conhecimento que ajude a inventar possibilidades mais autônomas de existir e de conviver. 
- Todo conhecimento científico visa a constituir-se em senso comum.

Para Santos (1987: 55), a ciência moderna produz conhecimentos e desconhecimentos. Com ironia, afirma que "se faz do cientista um ignorante especializado, faz do cidadão comum um ignorante generalizado".

Ao contrário, o paradigma emergente sustenta que nenhuma forma de conhecimento é, em si mesma, racional; somente a configuração de todas elas é racional. Tal paradigma tenta, pois, dialogar com outras formas de conhecimento, deixando-se penetrar por elas. E, de todas, a mais importante é o conhecimento do senso comum, o conhecimento vulgar e prático que orienta as nossas açôes no cotidiano e dá sentido à vida.

A ciência moderna constituiu-se em oposição ao senso comum, que a tomava por superficial, ilusória e falsa. Santos propõe a ideia de uma dupla ruptura epistemológica: após a diferenciação entre a ciência e o senso comum, um outro ato epistemológico; romper com a primeira ruptura e transformar o conhecimento científico em senso comum. Em outras palavras, significa "romper com o senso comum conservador, mistificado e mistificador, não para criar uma forma autônoma e isolada de conhecimento superior, mas para transformar a si mesmo num senso comum novo e emancipatório" (Santos, 2001: 107).

Um dos campos de transformação propostos pela Reforma Psiquiátrica é o campo sociocultural. Trata-se aqui de operar transformações no imaginário social sobre a loucura, a doença mental etc. Quer dizer, propóe-se que todo conhecimento produzido por esse processo seja incorporado como um bem cultural, que faça parte do senso comum.

Contrariamente à afirmação de que "lugar de louco é no hospício", busca-se provocar e transformar a cultura para uma concepção mais inclusiva e acolhedora à diferença.

\section{A REFORMA PSIQUIÁTRICA E A TRANSIÇÃO PARADIGMÁTICA}

A Reforma Psiquiátrica é um processo social complexo que transcende e supera as reformulações na organização dos serviços de saúde e as propostas de implementação de caráter exclusivamente técnicas. Supõe a renúncia da vocação terapêutica instituída por intermédio da superação do paradigma 
psiquiátrico, o que significa negar a instituição manicomial, romper com a racionalidade e o saber psiquiátrico sobre a doença mental, compreendido como um processo histórico e social de apropriação da loucura; questionar o poder do especialista (psiquiatra, psicólogo, enfermeiro etc.) em relação ao paciente e negar o seu mandato social de custódia e exclusão. Frisa Amarante (1997: 165):

Se fosse oportuno, neste contexto complexo, questionar-se quanto ao principal objetivo da Reforma Psiquiátrica, talvez fosse possível responder que seria poder transformar as relações que a sociedade, os sujeitos e as instituições estabeleceram com a loucura, com o louco e com a doença mental, conduzindo tais relações no sentido da superação do estigma, da segregação, da desqualificação dos sujeitos ou, ainda, no sentido de estabelecer com a loucura uma relação de coexistência, de troca, de solidariedade, de positividade e de cuidados.

Como já destaquei anteriormente, a palavra 'reforma', utilizada na designação da Reforma Psiquiátrica, ${ }^{35}$ não faz jus, pelos problemas que o termo provoca, à riqueza e à complexidade do que aqui estou a relatar. Em diálogo com Foucault, a respeito da relação entre os intelectuais e o poder, Deleuze critica a noção de reforma, afirmando:

Ou a reforma é elaborada por pessoas que se pretendem representativas e que têm como ocupação falar pelos outros, em nome dos outros, e é uma reorganização do poder, uma distribuição de poder que se acompanha de uma repressão crescente. Ou é uma reforma reivindicada, exigida por aqueles a que ela diz respeito, e aí deixa de ser uma reforma, é uma ação revolucionária que por seu caráter parcial está decidida a colocar em questão a totalidade do poder e de sua hierarquia. (Foucault, 1979: 72)

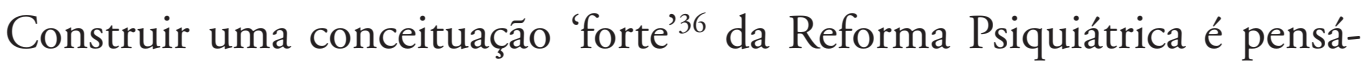
la como uma ação revolucionária desse tipo. Trata-se de uma radical ruptura com o modelo asilar predominante, por meio não só de um questionamento de seus conceitos, fundamentos e de suas práticas moldadas em uma questionável racionalidade científica, mas, principalmente, da construção de novo paradigma científico, ético e político. É nessa ruptura

\footnotetext{
${ }^{35}$ Amarante (2003), autor em parte responsável pela divulgação do termo Reforma Psiquiátrica, apresenta uma discussão na qual informa e contextualiza a sua origem, os seus usos e os sentidos.

${ }^{36}$ Conforme expus na Apresentação deste trabalho.
} 
que entendo o conceito de Reforma Psiquiátrica e não apenas no sentido de uma mudança de lócus e de técnicas de cuidado e gestão de serviços de saúde mental.

A crítica radical à psiquiatria tradicional, efetuada desde os anos 70 , produziu uma mudança na concepção do objeto, focado na doença, com uma decorrente prática centrada quase que exclusivamente na figura do médico, para uma concepção que busca superar as dicotomias saúde/doença, individual/social. Constituiu um campo complexo, composto por uma rede de fatores sociais, psicológicos, culturais e biológicos. Nessa perspectiva, trata-se de tomar o drama do existir humano em sua complexidade.

Costa-Rosa (2000) nomeia o conjunto das práticas promovidas pela Reforma Psiquiátrica como "modo psicossocial", em um movimento dialético de contradição ao modelo psiquiátrico tradicional, o qual chama de "modo asilar" predominante. Para o autor, a fim de caracterizar a mudança de paradigma de atenção capaz de superar o modelo asilar, é imprescindível que a prática preencha algumas condições relativas a transformações radicais em quatro âmbitos:

1) Concepção do objeto e dos meios de trabalho: contrapondo-se à ênfase nas determinações orgânicas e sua decorrente prática e ao meio de trabalho que reproduz modelo da divisão de trabalho correspondente à 'linha de montagem', o modo psicossocial caracteriza-se pela transformação nas concepções do objeto e na participação e implicação do sujeito no tratamento, tendo como meio de trabalho a equipe interprofissional, que, pelo intercâmbio entre seus saberes e práticas, supera radicalmente o modelo da linha de montagem.

2) Concepções das formas da organização institucional: opondo-se à organização verticalizada e a um fluxo de poder em sentido único do modo asilar, o modo psicossocial se caracteriza por uma organização institucional dos dispositivos de trabalho horizontal, no qual a participação, autogestão e interprofissionalidade são as metas radicais.

3) Formas do relacionamento com a clientela: enquanto o modo asilar se caracteriza pela separação entre doentes e sãos, com a instituição cumprindo uma função de depositária que interdita o diálogo, no modo psicossocial propõe-se que a instituição, por meio de seus agentes, adquira o caráter de espaço de interlocução, agenciadora de subjetividades. E, tendo 
em vista a dimensão de suas ações no âmbito da saúde coletiva, a instituição deve funcionar como ponto de fala e escuta da população.

4) Concepção dos efeitos típicos em termos terapêuticos e éticos: enquanto no modo asilar se observa uma hipertrofia nos 'defeitos de tratamento', como a cronificação asilar, decorrente de um entendimento do tratamento centrado na supressão ou no tamponamento dos sintomas, o modo psicossocial objetiva o reposicionamento subjetivo, levando-se em conta a dimensão coletiva e sociocultural. Deverá ser pensado na perspectiva de uma ética que se abra para a 'singularização'. Assim, implicação subjetiva e sociocultural, além da singularização, são as metas radicais quanto à ética das práticas no modo psicossocial.

Tenho como eixo central deste trabalho as quatro dimensões fundamentais do processo da Reforma Psiquiátrica apresentadas por Amarante (2003). Descreverei a seguir as características de cada uma delas, acrescentando minhas contribuições pessoais.

A DIMENSÃO EPISTEMOLÓGICA: é a que estou a tratar neste capítulo, e se refere ao campo da produção de saberes e à desconstrução dos fundamentos, das noções e dos conceitos fundantes da psiquiatria, como, por exemplo, a noção de doença mental. Não se trata apenas de negar, romper, mas também de produzir novas noções e conceitos, tecendo linhas que dialogam e articulam diferentes disciplinas, num esforço de construir um novo paradigma no campo da saúde mental.

A DIMENSÃO TÉCNICO-ASSISTENCIAL: em um constante movimento entre a prática e a teoria, ou seja, no movimento de uma práxis, propõe-se a construção de uma nova organização de serviços, articulando uma rede de espaços de sociabilidade, de produção de subjetividades, de geração de renda, de apoio social, de moradia, enfim, de produção de vida.

A DIMENSÃO JURÍDICO-POLíTICA: no primeiro capítulo, sugeri uma pequena alteração, renomeando-a como dimensão política. O termo jurídico colocado à frente, embora não seja essa a ideia fundamental, remete a uma ênfase nas mudanças das leis. $O$ sentido da alteração é salientar o processo de ação de protagonistas em diferentes segmentos sociais (movimento social, reforma do Estado, universidades etc.). São ações que objetivam construir uma nova pactuação de poder, lutando para dar voz a quem não tem direito, a quem não é cidadão. Trata-se, enfim, de uma luta política para uma transformação social. 
A DIMENSÃO SOCIOCULTURAL: há um imaginário social, construído historicamente, para a loucura, para a diferença. Um imaginário que desqualifica ("Isso é coisa de louco!"), que exclui ("Lugar de louco é no hospício!"), que teme ("Louco é perigoso e agressivo!"), que infantiliza ("Que bonitinho! Nem parece feito por louco!"). Provocar a sociedade a refletir sobre sua relação com a loucura, com objetos e ações culturais. Transformar, como diz Santos, o conhecimento e as práticas em um senso comum emancipatório. Enfim, produzir uma transformação desse imaginário é o grande desafio desta dimensão.

Em O Homem e a Serpente, Amarante sublinha a importante contribuição da produção de Franco Basaglia, psiquiatra italiano, referência teórica e prática da Reforma Psiquiátrica, a qual "pode ser entendida como um importante marco de referimento de uma 'fase de transição' do paradigma psiquiátrico-moderno, que se situa numa transição maior, que é a da ciência da modernidade" (Amarante, 1996: 24).

Como marco exemplar dessa transição, podemos destacar uma das principais proposiçôes basaglianas, inspirada na filosofia fenomenológica de Husserl, a de "colocar a doença entre parênteses". Trata-se de uma inversão da operação produzida pela racionalidade positivista da psiquiatria, que colocou o sujeito entre parênteses e se limitou à "definição das síndromes em que o doente, arrancado de sua realidade e apartado do contexto social em que vive, vê-se etiquetado, 'constrangido' a aderir a uma doença abstrata, simbólica e, enquanto tal, ideológica” (Basaglia, 2005: 35).

Com essa inversão, Basaglia propõe uma importante demarcação epistemológica que diz respeito ao saber psiquiátrico que se construiu em torno das definições abstratas de doença, as quais reduzem o sujeito a uma coleção de sintomas e sinais, a uma espécie catalogável e categorizável e que tem consequências éticas e políticas.

Para Amarante (1996: 84-85),

a doença entre parênteses é, ao mesmo tempo, a denúncia e a ruptura que permite a observação do duplo da doença mental, isto é, do que não é próprio da condição de estar doente, mas de estar institucionalizado (e não apenas internado), que reabre a possibilidade de um outro conhecimento sobre esta mesma condição. 
Nessa perspectiva, surge outro importante conceito para a Reforma Psiquiátrica: a desinstitucionalização. Formulado no âmbito da experiência italiana, tal conceito amplia os horizontes teóricos e técnicos do campo da saúde mental e tem inspirado e orientado boa parte dos trabalhos desenvolvidos no Brasil. Segundo o autor,

a desinstitucionalização na psiquiatria, na tradição basagliana, inscreve-se neste período de transição, onde se inicia uma fase de afastamento do paradigma clássico, com sua desmontagem, e a conseqüente abertura de um novo contexto prático-discursivo sobre a loucura e o sofrimento humano. Isso significa que, ao abrir um processo de recomplexificação da loucura, contribui com algumas estratégias cognitivas e práticas para o campo da teoria das ciências e do conhecimento (Amarante, 1996:31)

E, finalmente, o autor enfatiza uma característica do processo de desinstitucionalização, que podemos considerar como a face mais marcante e mais cotidiana do processo da Reforma Psiquiátrica brasileira: a possibilidade de

construir e inventar novas perspectivas de vida e subjetividade para aqueles mesmos sujeitos, e não apenas 'evoluçóes' e 'prognósticos' da doença mental (...) A complexidade, enfim, reporta ao problema ético das relaçôes entre os homens e para com a natureza, porque coloca o problema do pensar e agir em termos de relações e não de objetos. (Amarante, 1996: 33)

Esta não é apenas uma ruptura epistemológica aos fundamentos do saber e da prática da psiquiatria. A Reforma Psiquiátrica insere-se em um campo mais amplo, o da Reforma Sanitária, que tem configurado um novo campo, o da saúde coletiva.

Paim e Almeida Filho (1998) discutem o paradigma da saúde pública, concluindo que, apesar de não preencher as condições epistemológicas para se constituir em um novo paradigma, a saúde coletiva, enquanto movimento ideológico comprometido com a transformação social, evidencia possibilidades de articulação com novos paradigmas científicos capazes de abordar o objeto saúde-doença-cuidado respeitando sua historicidade e integralidade. Apresentam-na como um campo científico e um âmbito de práticas aberto à incorporação de propostas inovadoras. 


\section{Esclarecem os autores:}

A partir destas reflexôes, constata-se a afirmação de um campo interdisciplinar dinâmico, renovado e recomposto a partir de uma produção teórica ousada e consistente, ainda enfrentando diversas interrogações e dilemas. De fato, a conjunção das "crises da saúde" - científica, econômica, social e política - lança complexos desafios para a saúde coletiva quanto ao que fazer para efetivamente se articular aos novos paradigmas da saúde para o século XXI. (Paim \& Almeida Filho, 1998: 312)

Assim como na Reforma Psiquiátrica, trata-se aqui, no âmbito da produção de conhecimento, de reconfigurar o objeto privilegiado 'saúde'. Os autores destacam a necessidade de uma apreensão pragmática alimentando uma práxis, em vez de constituir-se em mera produção e incorporação de tecnologia:

Muito do que em um dado paradigma se pode tomar como um aparente paradoxo deve-se ao fato de que não se lida com um objeto obediente às determinações da predição, aquela das antecipaçôes limitadas e limitantes, rigorosas e precisas. Efetivamente, o objeto da saúde coletiva é muito mais tolerante a formas aproximadas de antecipação do seu processo, ressaltando a natureza nãolinear da sua determinação e a imprecisão (ou borrosidade) dos seus limites. (Paim \& Almeida Filho, 1998: 312)

A ruptura com os paradigmas vigentes não deve se restringir a um movimento de recusa e denúncia. A ruptura radical implica todos os atores envolvidos nesse amplo campo em intensos e incessantes movimentos de

crítica, elaboração e superação. É um movimento processual, que mobiliza os desejos dos atores e sujeitos no âmbito da práxis e que provoca uma transformação e uma construção no plano epistemológico, as quais retornam e alimentam o pensamento e a ação.

\section{CONCLUSÃO}

Ao longo deste capítulo, busquei explicitar as principais características do que poderia chamar de uma ruptura paradigmática. Embora, no transcorrer dos anos, encontremos inúmeras experiências singulares que, de certa forma, já se fundamentavam em alguns desses conceitos, é a partir da 
Reforma Psiquiátrica que essa ruptura, operada e concretizada cotidianamente na prática das novas instituições, conquistou maior visibilidade. Foi contagiando e contaminando outros operadores, outros profissionais, que foram criando e inventando outras instituições e outras novas práticas.

No Quadro 1, sintetizo alguns elementos que julgo essenciais para compreender essa transição de um modelo a outro. Em uma das colunas, caracterizo o modelo psiquiátrico tradicional que se fundamenta na racionalidade médica. Já para o novo paradigma, exatamente por estar sendo tecido, marcado por sua imprecisão, sua transitoriedade, irei nomeá-lo duplamente: como atenção psicossocial ${ }^{37}$ e como novo modelo assistencial, tal como propõem os documentos oficiais do Ministério da Saúde.

O modelo psiquiátrico tradicional, construído historicamente a partir do século XVIII, tem como objeto central de seu domínio e de sua intervenção a doença mental. Há um distúrbio que se localiza no corpo e que se manifesta em alterações nas formas de ser e de existir do sujeito, fugindo a um padrão de normalidade. Esse distúrbio pode ser reduzido, em sua determinação, a fatores localizáveis no organismo.

\section{Quadro I - Principais características do modelo psiquiátrico e da atenção psicossocial}

\begin{tabular}{|lll|}
\hline & Modelo psiquiátrico & $\begin{array}{l}\text { Atenção psicossocial/ } \\
\text { Novo modelo assistencial }\end{array}$ \\
\hline Objeto & Simples doença mental & $\begin{array}{l}\text { Complexo } \\
\text { existência-sofrimento }\end{array}$ \\
\hline Pressuposto teórico-conceitual & Campo das neurociências & Campo transdisciplinar \\
\hline Estratégias de intervenção & $\begin{array}{l}\text { Isolamento e } \\
\text { predominantemente biológica }\end{array}$ & $\begin{array}{l}\text { Predominância da diversidade } \\
\text { e da invenção }\end{array}$ \\
\hline Agente do cuidado & Médico & Coletivos \\
\hline Lugar do cuidado & Hospitalização & Rede e intersetorialidade \\
\hline Prática social & Exclusão/violência & Inclusão e solidariedade \\
\hline
\end{tabular}

Este olhar sobre o objeto pressupõe um marco teórico-conceitual e instrumentos de análise que se situam no campo da psiquiatria, que, ainda

${ }^{37}$ Conforme apresentado no texto Atenção Psicossocial: rumo a um novo paradigma na saúde mental coletiva, de Costa-Rosa, Luzio e Yasui (2003). 
carente de consistência científica, almeja estabelecer relações e ingressar no campo das neurociências.

A estratégia de intervenção, que daí decorre, será predominantemente biológica, ou seja, essencialmente psicofarmacológica, sendo que outras disciplinas comparecem apenas como coadjuvantes. $\mathrm{O}$ isolamento será a estratégia adequada para o enfrentamento das crises que não podem ser silenciadas.

Objeto, marco teórico e estratégia de intervenção definem uma lógica assinalada pela racionalidade científica, a qual terá, na figura do médico, o seu principal agente do cuidado, tendo como consequência a subordinação da prática de outros profissionais à sua decisão e orientação, caracterizando assim um modelo médico-centrado e uma hierarquização das profissóes no interior das instituições.

Isolar para conhecer e conhecer para dominar. Estes são os postulados que legitimaram o hospital psiquiátrico como lócus desse paradigma. Porém, sua lógica não se restringe ao espaço físico asilar e se atualiza mesmo nas instituições que, aparentemente, se propõem alinhadas com os modelos substitutivos.

A prática social decorrente desse modo é a do controle social, da exclusão do diferente e da violência institucionalizada.

Já a atenção psicossocial vem sendo tecida ao longo dos últimos anos, com os múltiplos fios de diversas disciplinas e experiências concretas. Rompendo com o paradigma psiquiátrico e, por conseguinte, com a racionalidade médica, trata-se aqui de tomar a existência humana em sua complexidade. E, nela, o sofrimento psíquico.

Falar de sofrimento significa falar da dor do corpo, da ansiedade, da angústia. Sofrimento também remete ao sofrimento de viver, das dificuldades impostas pelo modo de vida, marcado pela dimensão social, pela penúria, pela miséria. Do sertão que há em toda parte. Agregar o termo 'psíquico' à palavra 'sofrimento' não significa estabelecer uma divisão ou um corte entre mente/corpo. Significa enfatizar. Olhamos para a complexidade da existência humana por esse viés da singularidade, da subjetividade. Ou seja, incluímos essa dimensão que compreende uma intrínseca relação entre o conjunto de conteúdos da consciência e do inconsciente humano, que estão presentes nos estados e processos da experiência subjetiva e que se constituem/constroem/ tecem na relação do sujeito com o seu entorno social, familiar, cultural etc. 
Se entendemos o sofrer e a vida, em sua complexidade, só poderemos assumir, como pressuposto teórico, algo da ordem que contemple e sustente tal diversidade de olhares. Estamos, pois, no campo nomeado por Morin como o da complexidade, ou, por Santos, como de um paradigma prudente para uma vida decente, ou de Prigogine e Stengers, como o de uma "nova aliança". Adota-se uma postura de profunda humildade frente à diversidade e de um aberto e intenso diálogo, que cruza e perpassa as diferentes disciplinas.

Desta perspectiva e marco teórico, somente podemos então pensar em estratégias de cuidado que produzam e promovam a autonomia e a singularização do sujeito. E estas serão, também, da ordem da diversidade e da multiplicidade. Nesse sentido, o conceito de clínica se transforma. Não uma clínica inspirada no reclinar-se sobre o leito do paciente, com olhar de quem observa e busca a doença. Lugar onde as identidades dos participantes estão predefinidas. Mas uma clínica do encontro, da invenção e da produção de sentidos.

Assim, o lugar será qualquer um onde houver possibilidade de encontro com a vida e com a autonomização do sujeito. Um serviço substitutivo deve necessariamente ser pensado como um dispositivo que tece (no sentido de trabalhar a urdidura e a trama) e ativa uma rede de cuidados.

Os agentes serão os coletivos, mais do que as equipes multiprofissionais que apenas se constituem de profissionais compartilhando um mesmo espaço. Serão os cuidadores de distintas profissões e de distintas instituições dispostos a articular e a construir/inventar esse dispositivo de cuidado. $\mathrm{E}$ mais além: serão os familiares, os amigos, os colegas da escola, do trabalho, enfim, todo aquele que se puder implicar nesta ampla rede de cuidados.

Há uma ética que perpassa todo esse trabalho. Ele só pode ser concretizado como uma prática social que sonha utopias, que trabalha e acredita em uma sociedade mais justa e igualitária, que respeite radicalmente as diferenças. Só pode ser então uma prática norteada pela perspectiva da transformação social, ainda que ela seja uma utopia. Todavia, que seja uma utopia ativa, cujo percurso se concretiza a cada gesto cotidiano de cuidado com o sofrimento psíquico.

Se o sertão está em toda a parte, há que se encontrar as veredas e, igualmente, há que se construir veredas. Há que ser tão veredas. 


\title{
3 \\ CAPS
}

estratégia de produção de cuidados

\author{
Eu vou cuidar do seu jardim \\ Eu vou cuidar, eu cuidarei muito bem dele \\ (...) Eu cuidarei do seu jantar \\ Do céu e do mar, e de você e de mim
}

Nando Reis

Neste capítulo pretendo realizar uma reflexão sobre a dimensão técnicoassistencial, definida por Amarante $(1999,2003)$ como a constituição de uma rede de novos serviços, como espaços de trocas, de sociabilidade e de subjetivação, a partir da descontrução dos conceitos que sustentam a prática psiquiátrica e a reconstrução de novos conceitos.

Como já registrado neste trabalho, o processo da Reforma Psiquiátrica nasceu como um movimento social que traz a marca de seu tempo. No contexto das mudanças sociais e políticas nacionais, os protagonistas da reforma propõem transformações no modelo assistencial em saúde mental, com impactos e consequências que extrapolam esse subsetor da saúde. Tal processo se concretiza por meio da constituição de uma rede de serviços de atenção e cuidados que produziu e acumulou saberes e práticas, cujos princípios e conceitos mais importantes a caracterizam como uma ruptura com o modelo psiquiátrico tradicional. Ruptura consoante com a crítica aos paradigmas da ciência moderna, realizada por diversos autores que indicam, também, para a emergência de um novo paradigma nas ciências.

Temos aqui uma práxis: conceitos que nascem de uma prática de mudança da assistência em saúde mental e que se transmutam em instrumentos teóricos e técnicos para transformar essa mesma prática. 
Em seu Dicionário de Politica, Bobbio, Matteucci e Pasquino (2000: 991) destacam os diversos sentidos do conceito de práxis, afirmando que Marx

encara o problema da relação da teoria com a Práxis, ao expor a necessidade de mudar o mundo e não apenas o interpretar (tese undécima sobre Feuerbach). Na primeira tese, ao considerar a Práxis como atividade perceptiva (ou seja, como ação que éao mesmo tempo conhecimento) e não como contemplação, ele estabelece um nexo entre teoria e Práxis, nexo que apresenta como existente desde o início, desde o momento da percepção que constitui a base do pensamento teórico.

A práxis é o fundamento do conhecimento. Exprime, também, o poder que o homem tem de transformar o ambiente externo, tanto natural quanto social, e o de ser transformado por esse mesmo processo. Quer dizer, atividade que se modifica a si mesma, ao modificar o ambiente.

Há uma intrínseca relação entre os processos da Reforma Sanitária e o da Reforma Psiquiátrica e de ambas, com respeito às mudanças sociais. Parafraseando Teixeira (1995), que afirmava ser a Reforma Sanitária uma prática em busca de uma teoria, podemos também assim nomear a Reforma Psiquiátrica: é uma práxis em busca de uma teoria.

Práxis que vem sendo construída por profundas transformações, as quais constituem um novo olhar para a loucura, redefinindo e elaborando conceitos que orientam a construção de uma nova estratégia e modalidade de cuidado. É essa estratégia de cuidado e os conceitos-ferramentas que a instrumentalizam que tenho a pretensão de abordar no presente capítulo.

Antes de prosseguir, gostaria de ressaltar o sentido do conceito de 'estratégia'. Ele surge como uma importante ferramenta conceitual em diferentes campos da saúde. Por exemplo, é utilizado como um conceito central no planejamento das ações de saúde. Para Carlos Matus e Mário Testa, ${ }^{38}$ com diferenças e particularidades, o planejamento estratégico é necessariamente político e deve considerar a realidade local com suas demandas, seus recursos, seus atores e, principalmente, o jogo de conflitos, contradições e interesses que ocorre em um determinado cenário social, político e econômico.

Nos últimos anos, o Programa Saúde da Família, importante proposta de transformação da assistência em saúde no campo da atenção básica, também

${ }^{38}$ Conforme se encontra em Giovanella e Amarante, (1994). 
tem sido nomeado como Estratégia Saúde da Família, em substituição ao termo 'Programa', que leva a um entendimento de uma proposta acabada, vertical, predeterminada, que não considera a realidade local.

O conceito de estratégia, descrito como "a arte de aplicar com eficácia os recursos de que se dispõe ou de explorar as condições favoráveis de que porventura se desfrute, visando ao alcance de determinados objetivos" (Houaiss, 2001), para mim, define precisamente um dos aspectos mais importantes da proposta de mudança do modelo assistencial que se está a construir no campo da saúde mental. Em um lugar, em um tempo, com diferentes atores e com os recursos disponíveis, aplica-se a melhor maneira de combinar esses elementos, para provocar, proporcionar, produzir ou construir um processo de transformação.

Defendo aqui que o Centro de Atenção Psicossocial (Caps), o principal instrumento de implementação da política nacional de saúde mental, deve ser entendido como uma estratégia de transformação da assistência que se concretiza na organização de uma ampla rede de cuidados em saúde mental. Nesse sentido, não se limita ou se esgota na implantação de um serviço. O Caps é meio, é caminho, não fim. É a possibilidade da tessitura, da trama, de um cuidado que não se faz em apenas um lugar, mas é tecido em uma ampla rede de alianças que inclui diferentes segmentos sociais, diversos serviços, distintos atores e cuidadores.

A equipe de saúde mental pode ser pensada como a mão que urde, porém jamais será a trama. Tecer essa rede de alianças em torno do cuidado é uma das dimensóes essenciais do nosso processo de trabalho. $\mathrm{O}$ cotidiano de um Caps é o de pensar, para cada um que busca cuidado, um projeto terapêutico, considerando a sua singularidade, a sua complexidade. Projeto que contemple uma diversidade de estratégias de cuidado. Um Caps é a articulação dos diferentes projetos com os diferentes recursos existentes no seu entorno ou no seu território.

E, como estratégia de mudança de modelo, possui conceitos que orientam a compreensão dessa realidade complexa, tal como é o existir humano em suas manifestaçôes de sofrimento psíquico. Eles se configuram como 'princípios' que organizam a rede de atenção e as estratégias de cuidado. Conceitos-ferramentas para operar sobre a realidade na perspectiva de uma mudança do modelo.

Nesse sentido, pretendo aqui cartografar alguns desses conceitosferramentas que a prática da Reforma Psiquiátrica vem criando/inventando, 
por meio da apropriação, redefinição, usurpação de conceitos e noções de distintos campos do saber. Rolnik afirma que todo cartógrafo é antes de tudo um antropófago, utilizando uma referência ao escritor Oswald de Andrade e ao Movimento Antropofágico. Talvez não seja muito se pensar que somos um pouco assim: filosofia, sociologia, antropologia, psicanálise, política, geografia, física, biologia são disciplinas pelas quais transitamos como nômades antropófagos, assimilando e incorporando saberes que possam ajudar a construir nossa rota, nesta viagem. Rolnik (1989: 15) argumenta:

Para os geógrafos, a cartografia - diferentemente do mapa, representação de um todo estático - é um desenho que acompanha e se faz ao mesmo tempo em que os movimentos de transformação da paisagem. Paisagens psicossociais também são cartografáveis. A cartografia neste caso acompanha e se faz ao mesmo tempo em que o desmanchamento de certos mundos - sua perda de sentido - e a formação de outros: mundos que se criam para expressar afetos contemporâneos, em relação aos quais os universos vigentes se tornam obsoletos.

Como o imigrante da Apresentação, depois de passar pelo campo político e pelo campo epistemológico da Reforma Psiquiátrica, chegamos ao campo dos conceitos que operam sobre a realidade. Não esperem deste viajante definiçôes precisas e definitivas sobre tais conceitos. Sou um nômade que traz um diário de viagem com anotações para compartilhar.

Retomando o objetivo deste capítulo e considerando a complexidade do processo que estamos a caracterizar, não podemos compreender a Reforma Psiquiátrica, ainda que estejamos a refletir sobre essa dimensão técnicoassistencial, apenas como a transformação de serviços de saúde. É muito mais. Trata-se do estabelecimento de uma estratégia de cuidados que envolve o reconhecimento do território e seus recursos, bem como a assunção da responsabilidade sobre a demanda desse território. Implica estabelecer uma estratégia de acolhimento ao sofrer e à demanda que se apresentar; a criação de projetos de cuidado e de uma diversidade de estratégias de cuidado articuladas em rede a esse território.

Assim, nas próximas linhas, pretendo refletir sobre a essência fundamental de deste trabalho, que é a produção dos atos de cuidar, e sobre os conceitos-ferramentas que o implicam ou o pressupõem: 1) território; 2) responsabilização; 3) acolhimento; 4) projeto de cuidado e a diversidade de estratégias; 5) tecer uma rede. 
São conceitos presentes no principal documento do Ministério da Saúde que normatiza as ações de saúde mental no âmbito do SUS: a portaria 336/2002, a qual, em seu artigo $4^{\circ}$, alínea a, define a seguinte característica para todas as modalidades de Caps (Caps I, Caps II, Caps III, Capsi e Caps ad): "responsabilizar-se, sob coordenação do gestor local, pela organização da demanda e da rede de cuidados em saúde mental no âmbito do seu território" (grifos meus).

Meu principal desejo aqui é provocar uma reflexão para a abrangência e a complexidade que está pressuposta nessa característica e para o processo de construção, reconstrução e invenção dessas ferramentas conceituais, indissociável do cotidiano dos novos serviços, embora nem sempre claras para os atores que as operam. Conceitos que não são apenas instrumentos do campo da Reforma Psiquiátrica: são conceitos que fazem refletir sobre a produção do cuidado no campo da saúde.

\section{CUIDAR: A ESSÊNCIA DO NOSSO COTIDIANO}

O cuidar é a essência de nosso trabalho cotidiano. Somos profissionais produtores de atos do cuidar. Porém, ao longo de mais de dois séculos, a racionalidade que sustentou e legitimou o cuidar, na psiquiatria, criou instituiçôes e práticas que são mais bem definidas como produtoras de práticas da violência. Não houve cuidar, mas produção de silêncio, negligência, indiferença. As diversas mortes de pacientes nos hospícios, que ainda hoje ocupam as páginas dos jornais e os relatórios de sindicância que habitam as gavetas dos burocratas de plantão, são exemplos que atestam essas afirmações. A desqualificação social do louco produz práticas sociais, mais ou menos legitimadas pela ciência, nas quais ele tem uma importância equivalente ao lixo que se recolhe das ruas. ${ }^{39}$ Uma proposta como a da Reforma Psiquiátrica, que representa uma ruptura com essa racionalidade médica, deve também se apresentar como a construção de um cuidar que se distancie dos crimes da paz cometidos em nome da razão. ${ }^{40}$

${ }^{39}$ Em 2005, na cidade de São Paulo, um morador de rua foi recolhido e encaminhado ao Hospital Psiquiátrico. Uma das justificativas era o seu mau cheiro. A outra, e mais relevante, é que ficava aos olhos de quem se dirigia a um importante 'templo de consumo' de alto luxo da cidade.

${ }^{40}$ Referências ao livro de F. Basaglia e F. O. Basaglia - Os Crimes da Paz (1977) - e ao documentário de Helvécio Ratton - Em Nome da Razão. 
Em seu artigo sobre o cuidado e a integralidade, Mattos (2004) emprega uma analogia interessante e muito próxima ao que estou aqui a trabalhar. Parafraseando a proposição "uma ciência prudente para uma vida decente", de Boaventura Souza Santos, propõe, no título, "um cuidado prudente para uma vida decente", consoante a crítica à racionalidade científica que apresentei anteriormente. Reflete sobre a prudência que se deve ter, ao utilizar o conhecimento para a produção do cuidado: "o que caracteriza melhor o cuidado é sua contribuição para uma vida decente, e não a sua cientificidade" (Mattos, 2004: 121).

Mais do que uma essência do trabalho na saúde, o cuidado é uma dimensão da vida humana que se efetiva no encontro.

Nessa mesma perspectiva, podem-se encontrar contribuições do teólogo Leonardo Boff, cujas reflexões sobre o cuidado são interessantes e pertinentes para o nosso campo. Ele afirma que o cuidar "é mais que um ato; é uma atitude. Portanto abrange mais do que um momento de atenção, de zelo e de desvelo. Representa uma atitude de ocupação, preocupação, de responsabilização e de envolvimento afetivo com o outro" (Boff, 2002: 33).

Boff cita Martin Heidegger, para quem o cuidado significa um fenômeno ontológico-existencial, ou seja, é a base possibilitadora da existência humana. Para fundamentar essa afirmação, Heidegger, no seu livro $O$ Ser e o Tempo, recorre a uma metáfora, apresentando uma fábula-mito de Hygino sobre o cuidado. Eis a fábula:

Certo dia, ao atravessar um rio, Cuidado viu um pedaço de barro. Logo teve uma idéia inspirada. Tomou um pouco do barro e começou a dar-lhe forma. Enquanto contemplava o que havia feito, apareceu Júpiter. Cuidado pediu-lhe que soprasse espírito nele. O que Júpiter fez de bom grado. Quando, porém, Cuidado quis dar um nome à criatura que havia moldado, Júpiter o proibiu. Exigiu que fosse imposto o seu nome. Enquanto Júpiter e o Cuidado discutiam, surgiu, de repente, a Terra. Quis também ela conferir o seu nome à criatura, pois fora feita de barro, material do corpo da Terra. Originou-se então uma discussão generalizada. De comum acordo pediram a Saturno que funcionasse como árbitro. Este tomou a seguinte decisão que pareceu justa: "Você, Júpiter, deu-lhe o espírito; receberá, pois, de volta este espírito por ocasião da morte dessa criatura. Você, Terra, deu-lhe o corpo; receberá, portanto, também de volta o seu corpo quando essa criatura morrer. Mas como você, Cuidado, foi quem, por primeiro, moldou a criatura, ficará sob seus cuidados enquanto ela viver. E uma vez que 
entre vocês há acalorada discussão acerca do nome, decido eu: esta criatura será chamada Homem, isto é, feita de húmus, que significa terra fértil. (apud Boff, 2002: $45-46)^{41}$

É o ato de Cuidado que molda o corpo na massa disforme tirada da Terra. É o Cuidado que possibilita a vida, ao convidar Júpiter a dar seu sopro, para que a alma habite o corpo. E é o tempo-história, encarnado em Saturno, que nomeia o homem e dá a ele o seu destino. Aquilo que é humano se constitui, se mantém e se afirma pelo ato do Cuidado. Afirma Boff (2002: 190):

O espírito se humaniza e o corpo se vivifica quando são moldados pelo cuidado. Caso contrário, o espírito se perde nas abstrações e o corpo se confunde com a matéria informe. $\mathrm{O}$ cuidado faz com que o espírito dê forma a um corpo concreto, dentro do tempo, aberto à história e dimensionado para a utopia (Saturno).

A palavra deriva do latim coera, que era usada num contexto de relaçóes de amor e amizade, expressando a atitude de cuidado, de desvelo, de preocupação e de inquietação pela pessoa amada ou por um objeto de estimação. Prosseguindo, Boff (2002: 91) acrescenta:

Outros derivam cuidado de cogitare-cogitatus (...). O sentido (...) é o mesmo de cura: cogitar, pensar, colocar atenção, mostrar interesse, revelar uma atitude de desvelo e de preocupação. O cuidado somente surge quando a existência de alguém tem importância para mim. Passo então a dedicar-me a ele; disponhome a participar de seu destino, de suas buscas, de seus sofrimentos e de seus sucessos, enfim de sua vida.

Podemos encontrar condensados, nessas citações, elementos que parecem centrais para uma aproximação dessa essência de nosso cotidiano, que é a produção dos atos de cuidado. $\mathrm{O}$ cuidado é uma condição que permite, produz, mantém, preserva a vida humana frágil, fugaz. É uma atitude que se dá sempre na relação entre seres. Cuidar não pode ser apenas realizar ações visando a tratar a doença que se instala em um indivíduo. Ou seja, o cuidador não é somente um profissional especializado que executa um conjunto de ações técnicas. $\mathrm{O}$ sujeito não se reduz a uma doença ou a uma lesão que lhe causa sofrimento. Cuidar remete a um posicionamento comprometido e implicado em relação ao outro. Nesse sentido, aproxima-se

${ }^{41}$ A tradução é do próprio Boff. Há pequenas diferenças em relação à tradução que se pode ler na edição brasileira do livro de Heiddeger. 
muito da afirmação de Franco Basaglia de que é necessário colocar a doença mental entre parênteses, para que se possa enxergar o sujeito. ${ }^{42}$ Ver e ouvir aquele que tem uma história de vida pessoal, marcada pelas condições sociais, econômicas e culturais de um dado tempo e lugar. A doença deve ser colocada entre parênteses naquilo que esse conceito induz e tem como consequências olhares e práticas reducionistas. Como diz Ayres (2001: 71):

Cuidar da saúde de alguém é mais que construir um objeto e intervir sobre ele. Para cuidar há que se considerar e construir projetos; há que se sustentar, ao longo do tempo, uma certa relação entre a matéria e o espírito, o corpo e a mente, moldados a partir de uma forma que o sujeito quer opor à dissolução, inerte e amorfa, de sua presença no mundo. Então é forçoso saber qual é o projeto de felicidade que está ali em questão, no ato assistencial, mediato ou imediato. A atitude "cuidadora" precisa se expandir mesmo para a totalidade das reflexóes e intervençôes no campo da saúde.

Cuidar, em saúde, significa pensar em uma atitude de ocupação, preocupação, de responsabilização e de envolvimento com o outro. Para olhar e ouvir o outro, é preciso reconhecê-lo como alguém que represente mais do que um mero objeto de intervenção. Preciso reconhecê-lo como um sujeito, não como uma entidade, um objeto, uma doença. Isso representa uma ruptura epistemológica de grande importância, conforme abordei no capítulo anterior. Significa romper com uma racionalidade médica que instrumentaliza saberes e práticas hegemônicas centradas na doença, de caráter hospitalocêntrico, excessivamente farmacológico e de orientação biologizante. Ruptura que inaugura uma relação diferente entre o sujeito que sofre e o cuidador que toma o existir humano em sua complexidade. As estratégias de intervenção daí decorrentes ampliam-se para a construção de projetos marcados pela diversidade. Cuidar é montar, tecer projetos de vida. É uma relação.

Merhy e Franco definem o trabalho em saúde como relacional, porque depende do "trabalho vivo" em ato, isto é, trabalho no momento em que este é produzido. Chamam a atenção para características das relações produzidas por tal ato:

Estas relaçōes podem ser, de um lado, sumárias e burocráticas, onde a assistência se produz centrada no ato prescritivo, compondo um modelo que tem, na sua

${ }^{42}$ Como já destaquei no capítulo anterior, Amarante (1996) apresenta, de maneira detalhada e fundamentada em ampla pesquisa, essa proposta epistemológica de Basaglia. 
natureza, o saber médico hegemônico, produtor de procedimentos. Por outro lado, estas podem se dar como relações intersessoras estabelecidas no trabalho em ato, realizado no cuidado à saúde. (Merhy \& Franco, 2003: 318)

Merhy define "intersessores" 43 em alusão a Deleuze e utiliza o termo para designar o que se produz nas relações entre

"sujeitos", no espaço de suas interseçôes, que é um produto que existe para "os dois" em ato e não tem existência sem o momento da relação em processo, e na qual os intersessores se colocam como instituintes na busca de novos processos, mesmo um em relação ao outro. (Merhy, 2002: 51)

A proposta de ruptura com a racionalidade médica, que deveria estar presente no cotidiano dos novos serviços, encontra ainda inúmeras dificuldades em se efetivar. Tenho acompanhado o trabalho de muitos Caps, em diferentes regiōes do país e, mais de perto, em muitos municípios no interior do estado de São Paulo, que corroboram o alerta para as relações burocráticas. Com mais frequência do que gostaria, encontro uma organização dos processos de trabalho que ainda se norteia pelo modelo hegemônico da racionalidade médica, centrada nos fenômenos patológicos e no ato prescritivo. A presença do psiquiatra e os seus atos determinam a dinâmica e a estratégia terapêutica, via de regra, medicamentosa. As discussões de caso em equipe, quando existem, geralmente ocorrem sem a presença daquele profissional e tendem a reduzir o sofrimento psíquico ao quadro patológico. A utilização de outras estratégias não muda a lógica do modelo: a oficina terapêutica, por exemplo, transforma-se não em um campo relacional de trabalho vivo, de encontro, de criação, mas na mera reprodução de técnicas muitas vezes de caráter moralizante e de controle, que transformam a potencialidade criativa em trabalho repetitivo, sem sentido, burocrático. Encontro, também, o emprego de ferramentas conceituais das práticas hegemônicas: isolamento (ainda que em um serviço aparentemente aberto); discursos técnicos que calam o paciente (monólogo da razão sobre a loucura); a doença suplantando a complexidade da vida e a medicalização como estratégia terapêutica central.

${ }^{43}$ O termo é grafado como "intercessor" no livro Conversaçôes de Deleuze. Merhy usa a grafia "interseçores" no livro Saúde: cartografia do trabalho vivo e no artigo mencionado anteriormente usa "intersessoras", embora ambas as referências utilizem o conceito de Deleuze. Por fidelidade aos textos citados, mantive a grafia tal como ela aparece. Ao longo do capítulo, ao me referir ao conceito de Deleuze, utilizarei a grafia "intercessor" porque é a dicionarizada. 
Para romper essas relações burocráticas, é necessário ousar, inventar, correr riscos. A produção de novas relações e a construção de projetos de vida autônoma não se dão em lugares com relações mediadas pelo medo, pela covardia, pelo comum, na mesmice, na mediocridade. Entenda-se medíocre aqui algo de qualidade média, modesto, sem expressão ou originalidade, pouco capaz, sem qualquer talento, que, de modo geral, fica aquém. Quer dizer, serviços absolutamente comuns, que reproduzem as mesmas práticas que podemos nomear de manicomiais ou asilares.

Pelo contrário, produzir cuidado por meio do encontro de subjetividades, na perspectiva de uma ruptura epistemológica com as práticas hegemônicas, significa coragem para correr riscos, abrir-se para a potencialidade produtiva do encontro, do bom encontro, como nos fala Espinosa. Produção de afetos, como sentimento amoroso, mas também como instigação, mudança.

Não é meu intuito desenvolver ou detalhar a filosofia de Espinosa, contudo, gostaria de assinalar alguns pontos que merecem atenção, pois provocam reflexóes sobre o nosso cotidiano, como produtores de atos de cuidado.

$\mathrm{Na}$ filosofia de Espinosa, tudo na natureza participa de uma ordem comum de encontros, e os seres podem ser definidos pelo seu poder de "afetar" e de serem "afetados" por outros seres. Trata-se sempre de um encontro de corpos e, também, de ideias, que pode ser considerado bom ou mau. Um bom encontro é como um alimento, ou um ser amado, que se compõe com o nosso corpo e aumenta nossa potência de existir, de agir e pensar. Um mau encontro é, ao contrário, aquele em que um corpo, ou uma ideia, não se compõe com meu corpo e com minhas ideias, deixando-me, por isso, mais fraco. O mau encontro é como a ingestão de um veneno ou a relação com um inimigo: ele decompóe parcial ou totalmente os elementos que nos constituem e diminui ou destrói nossa potência de existir, agir e pensar.

Essa potência que se fortalece ou enfraquece com os encontros, esse poder de afetar ou ser afetado, que produz um movimento interno do corpo e o nexo das ideias na alma, constitui uma essência que Espinosa denomina conatus. Conatus é o esforço para perseverar na existência, poder para vencer os obstáculos exteriores a essa existência, poder para expandir-se e realizarse plenamente. Deleuze entende esse conceito como potência para agir e, para ele, toda a potência é em ato, é ativa. Ele explicita: 
Podemos dizer que a alegria aumenta nossa potência de agir, e a tristeza a diminui. E o conatus é o esforço para experimentar alegria, ampliar a potência de agir, imaginar e encontrar o que é causa de alegria, o que mantém e favorece esta causa: mas é também esforço para exorcizar a tristeza, imaginar e encontrar o que destrói a causa de tristeza. (...) O conatus é, pois, esforço para aumentar nossa potência de agir ou experimentar paixões alegres. (Deleuze, 2002: 106-107)

Nesse sentido, parece-me que o ato de cuidar será sempre uma busca em produzir bons encontros. $\mathrm{O}$ ato de cuidar deve ser uma produção regida pela alegria, pela beleza, pela poesia. São os afetos alegres que produzem os bons encontros, que produzem potencialidade, que produzem vida.

Olhar e ouvir desse lugar do cuidado, daquele que investe o seu afeto e a sua atenção para produzir efeitos para potencializar a autonomia, apresenta às vezes resultados surpreendentes. Certa ocasião, conheci um paciente, morador de um grande hospital psiquiátrico por mais de quarenta anos, que era tido como mudo. Convidado a participar de atividades de oficinas expressivas e de grupos, começou, lenta e discretamente, a balbuciar alguns sons. Após algum tempo, os sons já se transformavam em vogais, sílabas. Mais um tempo, em palavras, pequenas frases. E, 'milagre', o mudinho falou! A conclusão é óbvia. Submetido a um cotidiano de violência institucional que lhe tirou tudo o que era mais importante de sua vida, não lhe restou outra saída a não ser silenciar para, talvez, preservar o pouco de sanidade que lhe restava. Já ouvi histórias semelhantes se repetirem em muitos outros serviços de saúde mental. Não há milagre, apenas um bom encontro que produz efeitos, que faz a diferença na vida das pessoas de que tomamos o encargo de cuidar.

Falar sobre cuidado é falar de uma produção de atos, regidos pela alegria e pela beleza, que produzem bons encontros, potencializando a vida. Parafraseando o poeta Vinicius de Moraes: o cuidado, assim como a vida, "é a arte do encontro, embora haja tanto desencontro pela vida" ${ }^{44}$

Para evitar o desencontro, o ato do cuidado também possui uma medida justa. $\mathrm{O}$ excesso de cuidado pode sufocar, produzir dependência. $\mathrm{O}$ cuidado não pode exceder certo limite, correndo o risco de tornar-se assistencialismo, gesto de caridade que transforma o sujeito em um uma pessoa incapaz de suprir suas necessidades mais básicas, em um objeto de exercício de ações benfeitoras de seres pretensamente superiores. $\mathrm{O}$ cuidado deve nortear-se

${ }^{44}$ Trecho da música "Samba da Bênção", de autoria de Vinicius e Baden Powell. 
pela justa medida de uma ética solidária. Caponi (2000: 95) afirma que, para poder existir, a solidariedade precisa "do respeito, da admiração, do reconhecimento do outro como alguém capaz de reclamar, aceitar ou negar assistência”.

E isso se torna especialmente importante se considerarmos o Caps não só como um serviço, mas como uma ampla produção de atos de cuidado que se faz em rede, em uma diversidade de estratégias executadas para além das fronteiras do serviço, integradas e em associação a outras instituições e serviços. Isso pressupõe um olhar para além da 'doença'. Um olhar sobre as necessidades das pessoas que acorrem e demandam ao serviço. Entender a saúde como uma produção social, em que agir sobre esses determinantes significa romper limites assistenciais, ousar e ir além. Mas, ao mesmo tempo, atentar para um tênue limite, além do qual corremos o risco de criar uma estratégia que pode ter a pretensão de totalizar e controlar a vida do indivíduo. O sonho de uma psiquiatria preventiva era o de se infiltrar na trama cotidiana da sociedade e localizar a doença e o doente antes mesmo de sua emergência. $O$ justo limite é aquele que se equilibra na 'corda bamba' da produção da autonomia atenta para não produzir dependência ou tutela. Equilíbrio entre a produção da liberdade ou da servidão voluntária.

\section{TERRITÓRIO}

O cuidado se faz com pessoas e em um determinado lugar, ou seja, se faz em um território.

O lugar das práticas psiquiátricas sempre se revestiu de especial importância. No Brasil, a frase "aos loucos o hospício", enunciada em 1830, pela Sociedade de Medicina, denunciava a situação na qual viviam os loucos no Hospital da Santa Casa da Misericórdia e exigia a criação de espaços diferenciados para um "verdadeiro tratamento" da loucura. Uma doença especial requeria, para ser tratada, de um lugar especial, definido e dirigido pelo saber médico. Machado e colaboradores (1978) e Cunha (1988) demonstram como o alienismo participa, com seu projeto de organização do espaço urbano e da manutenção da ordem social, da construção da sociedade brasileira do século XIX e início do século XX. O lugar de construção da maior parte dos hospícios brasileiros possui uma mesma característica: são lugares distantes do principal núcleo urbano da cidade. Concretizam, na arquitetura e na localização, 
uma de suas principais funções: a exclusão de indivíduos não adaptáveis ou resistentes à ordem social.

Costa (1981) nos relata a história da Liga Brasileira de Higiene Mental, que, nos anos 20 e 30, tem a pretensão de se constituir em um projeto de regeneração nacional, tomando como tarefa o saneamento racial brasileiro. Com um discurso preventivo de ideal eugênico, alargava o campo de atuação da psiquiatria para as diversas instâncias do social: a família, o trabalho, a escola. Birman e Costa (1994) analisam a proposta da psiquiatria preventiva norte-americana, a qual, nos anos 60 do século $\mathrm{XX}$, sem a conotação eugênica, mas com forte viés de controle, toma a sociedade como seu lócus privilegiado, objetivando a prevenção da doença mental por meio da detecção dos comportamentos desviantes e de risco. A psiquiatria, na sua relação com a sociedade, sempre foi o mais bem acabado exemplo do dispositivo da sociedade disciplinar que investe na normalização dos corpos, como afirma Foucault $(1979,1983)$ e, posteriormente como acrescenta Deleuze (1992), da sociedade de controle: do corpo dócil ao corpo útil, cúmplice, aparentemente participativo, consumidor.

Se nos colocamos na perspectiva de uma ruptura com essa racionalidade que determina o lugar do cuidado da loucura como o do isolamento, da exclusão, da disciplinarização, e também como dispositivo que penetra na sociedade como estratégia de controle, vigilância, domesticação, devemos estar atentos para as relações entre a produção de cuidado e o território no qual se inscreve o serviço.

Essa relação vem claramente enunciada, em diversos documentos, como a portaria n. 336/2002, já citada neste livro, a qual indica, como característica do Caps, "responsabilizar-se, sob coordenação do gestor local, pela organização da demanda e da rede de cuidados em saúde mental no âmbito do seu território". Essa mesma portaria estabelece, no parágrafo $2^{\circ}$ do artigo $1^{\circ}$, que os "Caps deverão constituir-se em serviço ambulatorial de atenção diária que funcione segundo a lógica do território".

Entendo por "lógica do território" um conceito central, norteador das ações a serem construídas pelo serviço. Afirmo que a existência do Caps como uma estratégia de organização da rede de cuidados está intrinsecamente associada ao tempo e ao lugar em que esta se constitui. Porém, devemos estar atentos, já que o território possui igualmente outras lógicas que produzem sujeição e dominação, distintas daquela que desejamos implementar. 
O território é uma categoria central nas análises do geógrafo Milton Santos. Ele nega a visão tradicional da geografia que considera o território como um objeto estático, com suas formações naturais, e o concebe como um objeto dinâmico, vivo de inter-relaçōes. Critica a visão descritiva da geografia, propondo uma revisão de seus fundamentos e métodos, para detalhar as influências recíprocas do território com a sociedade, seu papel essencial sobre a vida do indivíduo e do corpo social. Para ele, território engloba as características físicas de uma dada área e as marcas produzidas pelo homem. E define:

O território não é apenas um conjunto de formas naturais, mas um conjunto de sistemas naturais e artificiais, junto com as pessoas, as instituiçóes e as empresas que abriga, não importando o seu poder. O território deve ser considerado em suas divisões jurídico-políticas, suas heranças históricas e seu atual conteúdo econômico, financeiro, fiscal e normativo. É desse modo que ele constitui, pelos lugares, aquele quadro da vida social onde tudo é interdependente, levando, também, à fusão entre o local, o global invasor e o nacional sem defesa (no caso do Brasil). (Santos, 2002: 84)

Há uma inseparabilidade estrutural, funcional e processual entre a sociedade e o espaço geográfico. Para Milton Santos, o território, tomado como um todo dinâmico, permite uma visão não fragmentada e unificada dos diversos processos sociais, econômicos e políticos, o que possibilita revelar os grandes problemas nacionais. "Lugares e regiōes tornam-se tão fundamentais para explicar a produção, o comércio, a política, que se tornou impossível deixar de reconhecer o seu papel na elaboração dos países e do mundo" (Santos, 2002: 99). Tece críticas severas ao processo de globalização e seus efeitos, instalando uma nova forma de uso do território, impondolhe modificações súbitas aos conteúdos quantitativos e qualitativos e alterando todas as relações mantidas dentro de um país. Ressalta a noção de território como "um limite à ação cega das finanças", uma resistência ao dinheiro como o "único pressuposto, que fragmenta a sociedade" e resulta em uma "federação ingovernável". E conclui:

O território é onde vivem, trabalham, sofrem e sonham todos os brasileiros. Ele é, também, o repositório final de todas as ações e de todas as relações, o lugar geográfico comum dos poucos que sempre lucram e dos muitos perdedores renitentes para quem o dinheiro globalizado - aqui denominado de "real" - já não é um sonho, mas um pesadelo. (Santos, 2002: 84) 
A partir do exposto, trilharei a perspectiva de um entendimento do território que supera a noção de uma delimitação geográfica sobre a qual um determinado serviço se torna responsável pelo atendimento das pessoas adscritas àquele local. $\mathrm{O}$ conceito de território, como bem nos mostra Milton Santos, é relacional: diz respeito à construção e à transformação que se dão entre os cenários naturais e a história social que os homens inscrevem e produzem. Memória dos acontecimentos inscrita nas paisagens, nos modos de viver, nas manifestações que modulam as percepções e a compreensão sobre o lugar. Relação que surge dos modos de apropriação e de alienação desse espaço e dos valores sociais, econômicos políticos e culturais ali produzidos. Modos múltiplos, contíguos, contraditórios. Modos de construção do espaço, de produção de sentidos ao lugar em que se habita, ao qual se pertence por meio das práticas cotidianas. Organizar um serviço substitutivo que opere segundo a lógica do território é olhar e ouvir a vida que pulsa nesse lugar.

Pensar na organização de um Caps na cidade de Tefé, situada na floresta Amazônica, às margens do rio Solimões e distante a $600 \mathrm{~km}$ de Manaus, aonde se chega apenas de barco (dois dias de viagem) ou de avião, é diferente de pensar o Caps em Criciúma, cidade da região carbonífera do estado de Santa Catarina, ou em São Miguel Paulista, bairro da periferia leste da cidade de São Paulo. São territórios distintos, com suas histórias sociais, políticas e econômicas de ocupação e usos dos espaços. Histórias que determinam os lugares e as formas de acesso: os bairros nobres interditados aos pobres, exceto aos serviçais; a região do comércio com suas ruas de intensa movimentação; o comércio enclausurado nos shoppings centers; os parques e equipamentos de lazer; os bairros pobres; a região do meretrício etc. Histórias sociais que produzem marcas e formas peculiares de se expressar na mesma língua portuguesa, com palavras e sons particulares. Modos de expressão cultural que revelam influências de diferentes culturas: nas festas e celebrações, na culinária, na dança, na música. Territórios com sua base econômica e as formas de exploração do homem com suas consequências no modo de viver e levar a vida. A oferta, a organização, a distribuição e o acesso aos serviços e instituições públicas também trazem as marcas locais da construção das políticas públicas.

O território não é somente permanência, perenidade, não é apenas tradição cultural. É também mutação, produção e modificação intensa, norteadas pela lógica do capitalismo globalizado que intervém dissipando e desintegrando as fronteiras entre o local e o global, modificando relaçóes, 
gerando modos conformados e consumistas de existir. É no território que se exerce o controle das subjetividades. É nele que se instala o olho vigilante do poder disciplinar que se ramifica e adere às rotinas cotidianas, transmutando-as ao sabor das conveniências do mercado. E o que se vende com as mercadorias são modos de ser, novos mundos e novas formas coletivas de conceber a vida e a existência. Subjetividades capturadas e ansiosas pelo consumo.

Guattari (1992) analisa a sociedade contemporânea como o mundo da técnica e da desterritorialização, da produção de uma homogênese capitalística, que impõe uma equivalência generalizada dos valores, uma padronização dos comportamentos. A partir dos processos intermitentes de desterritorializações e reterritorializaçôes, desenvolveu, junto com Deleuze, a noção de heterogênese, para afirmar que é por meio dela que se produz algo novo e inusitado. Podemos pensá-la como busca permanente, no âmbito da vida cotidiana, de subjetivação pelo cultivo do dissenso, processo contínuo de produção singular da existência. Heterogênese diz respeito à produção do diferente, do diverso, daquilo que escapa da homogeneidade, do comum, do medíocre. Recomposição de territórios existenciais, reterritorialização, ou seja, é desfazimento de um território existencial e produção de outros simultaneamente. Guattari (1992: 171) afirma:

Poderiam os homens restabelecer relaçôes com suas terras natais? Evidentemente isso é impossível! As terras natais estão definitivamente perdidas. Mas o que se podem esperar é reconstituir uma relação particular com o cosmos e com a vida, é se "recompor" em sua singularidade individual e coletiva.

Para Guattari e Rolnik (2005: 42), a subjetividade é produzida por instâncias individuais, coletivas e institucionais:

A subjetividade está em circulação nos conjuntos sociais de diferentes tamanhos: ela é essencialmente social, e assumida e vivida por indivíduos em suas existências particulares. $\mathrm{O}$ modo pelo qual os indivíduos vivem essa subjetividade oscila entre dois extremos: uma relação de alienação e opressão, na qual o indivíduo se submete à subjetividade tal como a recebe, ou uma relação de expressão e criação, na qual o indivíduo se reapropria dos componentes da subjetividade, produzindo um processo que eu chamaria de singularização.

Nessa perspectiva, entendo que esta é a lógica do território que o Caps como estratégia deve seguir. Território como relação entre o natural e o 
social, como produção de subjetividades aprisionadas, mas também como potencialidade de disrupção, de criação de novos territórios existenciais, de espaços de afirmação de singularidades autônomas. O que significa encontrar e ativar os recursos de singularização locais existentes. Por exemplo, estabelecer alianças com grupos e movimentos de arte ou com cooperativas de trabalho para potencializar as ações de afirmação das singularidades e de inclusão social. Trata-se de criar uma intensa porosidade entre o serviço e os recursos do seu entorno. Significa também - e especialmente nos locais precários e homogeneizados - criar outros recursos, inventar e produzir espaços, ocupar o território da cidade com a loucura. Do manicômio, lugar zero das trocas sociais (Rotelli, Leonardi \& Mauri, 2001), ao espaço público como lócus terapêutico, de intervenção, de montagens e instalações permanentes.

Organizar uma associação de amigos, familiares e usuários; organizar eventos de celebração do dia (ou semana) da luta antimanicomial, com a participação e a cooperação com outras instituições do território; realizar intervençôes culturais, tais como exposições de trabalhos, apresentaçôes de teatro, dança e música; produzir e colocar em circulação, na cidade, jornal ou informativo sobre a saúde mental; utilizar espaços nas feiras livres, para mostra e venda da produção artesanal, são exemplos de como podemos ter o território como cenário dos encontros, como matéria-prima de processos de subjetivação, de autonomização. Encontros e ações provocativas e locais para produzir atos de cuidado para além do serviço, a fim de construir uma outra lógica assistencial em saúde mental, que se contraponha a uma racionalidade hegemônica e à lógica do capitalismo globalizado, para criar um novo lugar social para a loucura.

Será um lugar cuja construção apresenta riscos e perigos:

Ao borrarmos essa fronteira simbólica e concreta entre a sociedade e seus loucos não estaremos, sob pretexto de acolher a diferença, simplesmente abolindo-a? Não estaremos, como um carinhoso abraço de urso, conjurando o perigo que os loucos representam? Não estaremos, através de uma tecnologia soft, baseada na brandura e na diluição, domesticando a fera que os habita e nos livrando da estranheza que eles transmitem? Para dizê-lo de modo ainda mais incisivo, será que a libertação do louco não corresponde, no fundo, a uma estratégia de homogeneização do social? (Pelbart, 1993: 104)

A racionalidade moderna, encarnada no gesto de Pinel, retirando os grilhōes, também se ergueu como a libertadora dos loucos. Eis um grande 
desafio: construir um lugar que não borre os limites, homogeneizando; não domestique ou dome a loucura, retirando dela sua potencialidade de disrupção. Ao contrário, construir um lugar em que essa radical diferença da desrazão possa habitar em toda a sua plenitude provocativa, permeável e porosa a um estranho diálogo com a nossa racionalidade 'careta', mas sem a qual ainda não sabemos direito como viver. Construir esse lugar implica e significa nos reinventarmos na relação com esse novo lugar. Pensar, sentir e viver de forma diferente, intensamente diferente.

O conceito de território é, assim, um objeto complexo que deve ser igualmente abordado na perspectiva de se libertar o conhecimento local, advindo das necessidades locais, das realidades locais. O conhecimento local expresso nas práticas cotidianas, heterogêneas, é o conhecimento que contribui na produção de sentidos, para uma nova semântica do território e de seu viver.

Já destaquei que, para Boaventura de Souza Santos, no paradigma emergente, o conhecimento é também local, pois deve se constituir ao redor de temas que

em um dado momento são adotados por grupos sociais concretos como projetos de vida locais, sejam eles reconstituir a história de um lugar, manter um espaço verde, construir um computador adequado às necessidades locais, fazer baixar a taxa de mortalidade infantil, inventar um novo instrumento musical, erradicar uma doença, etc. (Santos, 1987: 47-48)

Essa perspectiva do território como processo, como relação, rompe com a noção de esquadrinhamento da sociedade, delimitando áreas de abrangência, considerando apenas o frio mapa de uma cidade. Trata-se aqui de construir/inventar um espaço possível de subjetivação. Talvez não seja muito pensar que, para uma proposta de um Caps, haverá para cada Caps um território com sua singularidade e, em cada Caps, tantos territórios quantos os usuários que lá se encontrarão.

Afirmei que o cuidado é uma produção de atos, regidos pela alegria e pela beleza, que produzem bons encontros, potencializando a vida. Acrescento que essa potencialização se dá na apropriação e na produção de sentidos do território, aqui entendido na complexidade desse conceito. 


\section{RESPONSABILIZAÇÃO}

Território e responsabilização são conceitos que aparecem relacionados nas práticas dos serviços substitutivos e em diversos documentos da saúde mental. Por exemplo, retomo, novamente, a portaria n. 336/2002 a propósito da caracterização do Caps: "responsabilizar-se, sob coordenação do gestor local, pela organização da demanda e da rede de cuidados em saúde mental no âmbito do seu território".

A experiência de maior êxito, ao menos no período de 1989-1996, ${ }^{45}$ da Prefeitura de Santos, que considero a mais radical na organização de serviços substitutivos de base territorial, contribuiu para a disseminação dessa relação entre território e responsabilização. Para Roberto Tykanori Kinoshita (1997: 73), coordenador da saúde mental naquele período:

O território para o serviço é a área sobre a qual o serviço deve assumir a responsabilidade sobre as questões de saúde mental. Isso significa que uma equipe deve atuar no território de cada paciente, nos espaços e percursos que compóem as suas vidas cotidianas visando enriquecê-lo e expandi-lo.

Para Nicácio (1994), essa responsabilização pela demanda implica duas questôes essenciais: atender à crise e à não separação entre prevenção, tratamento e reabilitação como instâncias isoladas.

Nessa perspectiva, a organização dos serviços de saúde mental em Santos rompia com a lógica da hierarquização por níveis de complexidade. Os Naps eram responsáveis por toda a demanda de saúde mental de seu território, abrangendo, assim, todos os níveis de atenção, buscando evitar a burocratização e a fragmentação da assistência, em função de uma racionalidade técnica ou administrativa. Para tanto, funcionavam 24 horas por dia, todos os dias da semana, de portas abertas e atendendo prontamente às situaçôes de crise.

\footnotetext{
${ }^{45}$ A partir de 1996, a gestão da Prefeitura de Santos mudou de partido, o que significou uma profunda mudança na concepção do trabalho lá desenvolvido. Embora os Naps ainda existam, perderam muito da essência radical que possuíam. Um projeto como aquele não se sustenta isoladamente. É, antes de tudo, uma proposta política de gestão e organização de políticas públicas, norteada por princípios que não fazem parte do ideário conservador dos partidos políticos que sucederam à gestão do PT. Nesse sentido, estou utilizando os verbos no tempo passado, relatando uma experiência exemplar que existiu e que continua como estratégia de resistência dos profissionais que, renitentes, têm tentando manter um pouco da essência daqueles anos passados. Koda (2002) analisa aqueles tempos, na voz dos profissionais, como sendo um tempo "épico", "heroico".
} 
Cada Naps responsabilizava-se no plural e no singular. No plural, olhava para o território no qual estava incluído, reconhecendo-o em suas características e demandas, e como possibilidade de construção de estratégias de cuidados que não se restringiam ao espaço do serviço, mas se ampliavam para além, para os espaços da vida, da circulação. E, no singular, assumia a responsabilidade de cuidar daquela pessoa concreta que se apresenta com seu sofrer ao serviço, não apenas no momento da crise, como também fora dela, construindo projetos de vida, de subjetivação, de autonomização. Nicácio (1994: 91) afirma:

Nesta perspectiva, os NAPS não são estruturas simplificadas como as instituições totais; são centros de atenção, de encontro, de produção de sociabilidade, de comunicação, de convivência, de referência cultural. Um lugar no qual cotidianamente se realizam novas formas para reconstituir a complexidade dos sujeitos e de seu poder social, acolher o sofrimento, reapropriação de história e vínculos com o mundo, ruptura de códigos, conquista de autonomia, laboratório de linguagens, afetos, emoções, mensagens, poderes, produção de sentido.

Esse conceito de responsabilização pela demanda do território, apresentado pela organização dos serviços de saúde mental de Santos, estava inspirado na experiência italiana de desinstitucionalização. Dell'Aqua e Mezzina (2005) nomeiam como "tomada de responsabilidade" a assunção de toda a demanda de uma região, ou a área territorial de referência, sem seleção de clientela, o que pressupõe um papel ativo na sua promoção e a ativação de diferentes recursos, e que significa assumir todo o alcance social da demanda do paciente. A partir das necessidades do paciente, o serviço assume todo o alcance social dessa demanda, ativando as organizações sociais, acompanhando ou apoiando em seu percurso. Não há um lugar definido ou exclusivo no qual ocorre a tomada de responsabilidade. Ela acontece no serviço de saúde mental, em outras instituições de saúde ou não e, sobretudo, no ambiente da vida do paciente, no qual ele exprime, exerce ou tenta exercer a sua sociabilidade. Se considerarmos, nas palavras de Rotelli, Leonardi e Mauri (2001), o manicômio como o lugar zero das trocas sociais, um lugar social de desvalor, os serviços substitutivos tomam a responsabilidade de produzir dispositivos, ações que buscam intervir no poder contratual do paciente nos distintos espaços e nas relações de sua vida, aumentado positivamente seu poder de participação nos processos de trocas sociais. Para Benedetto Saraceno (1996: 16), trata-se aqui de "um processo de reconstrução, um exercício 
pleno da cidadania e, também, de plena contratualidade nos três grandes cenários: habitat, rede social e trabalho com valor social".

Retornando aos Naps, além da responsabilização, gostaria de destacar uma outra característica daquela proposta: a porta aberta. Mais do que um sentido simbólico de oposição às formas de contenção e controle das instituiçōes asilares, como muros, grades etc., havia um significado propositivo: a garantia da universalidade do acesso ao serviço.

Alves e Guljor, com base em uma formulação de Saraceno, discutem a acessibilidade como critério de qualidade dos serviços de saúde mental, tal como descrito a seguir:

O critério de qualidade éa acessibilidade, que é determinada por três quesitos. $O$ primeiro é a localização geográfica, se o serviço está perto ou não das pessoas - $\mathrm{o}$ que chamamos de território. O segundo é o tempo que ele permanece aberto. Se o funcionamento se dá 24,12 ou 8 horas por dia; se funciona todos os dias ou apenas três vezes por semana - isso pode espelhar a qualidade do serviço. $\mathrm{O}$ outro quesito de qualidade integrante da formulação de acessibilidade diz respeito a quais programas estão acessíveis às pessoas que procuram o serviço. No caso de nossa clientela, programas propriamente assistenciais, de inserção social, lazer, hospitalidade assistida, trabalho assistido, dentre outros. (Alves \& Guljor, 2004: 230)

Acrescentaria mais um quesito à descrição: a organização do processo de trabalho e sua articulação com a rede assistencial de saúde podem favorecer, dificultar ou até mesmo impedir o acesso do usuário ao serviço. Trata-se aqui de se pensar na porta de entrada, observando se o serviço de saúde mental somente aceita usuários por meio de encaminhamentos feitos por outras unidades de saúde; se há longas listas de espera para o atendimento; se aceita ou não a demanda espontânea; a forma como é realizada a recepção do usuário e de sua família. São, todos, exemplos que podem dificultar, e muito, o acesso do usuário ao serviço, na medida em que se interpóem obstáculos burocráticos entre a sua necessidade e a potencialidade cuidadora da equipe.

Assim, território, responsabilização e qualidade técnica de um serviço de saúde mental se articulam, necessariamente, ao conceito de acesso. Nos termos em que tenho trabalhado, neste capítulo, o encontro que produz o cuidado, regido pela alegria e pela beleza, na apropriação e produção de 
sentidos do território, apenas é possível se o usuário acessar o serviço, os recursos de que ele dispõe para essa produção da vida.

Neste ponto, gostaria de enfatizar uma outra dimensão tanto do conceito de responsabilização quanto do de acesso. De acordo com o artigo 196 da Constituição Federal, a saúde "é um direito de todos e dever do Estado". A garantia desse direito se dá, de um lado, por meio da implementação de "políticas sociais e econômicas que visem à redução do risco de doenças e de outros agravos" e, de outro, por meio do "acesso universal e igualitário às ações e serviços para sua promoção, proteção e recuperação". A utilização do termo "acesso universal e igualitário" reconhece, constitucionalmente, a importância e a relevância das açôes e serviços de saúde como bem público. Em 1990, esse dispositivo constitucional foi regulamentado pela promulgação da Lei Orgânica da Saúde n. 8.080/1990, que criou o SUS, ao dispor sobre as condições para a promoção, proteção e recuperação da saúde, a organização e o funcionamento dos serviços correspondentes e ao regular, em todo o território nacional, as ações e serviços de saúde.

O SUS está organizado em torno de três diretrizes: a descentralização, com direção única em cada esfera de governo; o atendimento integral e a participação da comunidade, a qual está assegurada pela lei 8.142/1990, que dispõe sobre a participação da comunidade na gestão do SUS e sobre as transferências intergovernamentais de recursos financeiros na área da saúde. São dispositivos legais que colocam a saúde como uma política pública de responsabilidade do Estado, em suas esferas federal, estadual e municipal.

Hortale, Pedroza e Rosa (2000), em artigo no qual discutem uma proposta de operacionalização das categorias acesso e descentralização, em um modelo de análise de sistemas de saúde, apresentam como pressuposto que a saúde do indivíduo é uma responsabilidade social e consideram duas dimensões para a operacionalização desse modelo: a social e a política. $\mathrm{Na}$ dimensão social, o acesso é, segundo os autores, uma

categoria fundamental, independente das justificativas que possam ser dadas para a sua não-efetivação (custos excessivos, habilidade técnica, características da organização, etc.). $\mathrm{O}$ acesso deve funcionar no modelo como uma categoriavalor, ou seja, uma referência a ser atingida em qualquer serviço e ser o orientador de todas as políticas. Sua avaliação não pode se dar de forma simples, portanto, não podemos perder de vista que ele também deve abranger os vários planos do processo de produção de serviços. (Hortale, Pedroza \& Rosa, 2000: 232) 
Território, responsabilização e acesso são conceitos que se articulam no contexto de uma política pública de saúde, que, no caso brasileiro, foi construída a partir de um processo histórico de lutas políticas travadas na arena nacional, desde os anos 70 , no cenário da luta pela redemocratização do país e da construção de uma sociedade mais justa. Nesse processo, forjaram-se os princípios e diretrizes (acesso universal e igualitário, descentralização, integralidade, dentre outros) que foram acolhidos no texto da Constituição, conforme apresentei no primeiro capítulo.

A experiência de Santos surge aqui com todo o seu valor, porque teve início em uma fase anterior à regulamentação e à efetiva implantação do SUS, trazendo em seu projeto todo o ideário da Reforma Sanitária. Se o financiamento é um dos temas mais polêmicos e fonte de problemas do SUS, as ações inovadoras implantadas naquele período foram financiadas quase que exclusivamente pelo Tesouro municipal, numa clara demonstração da real possibilidade de se colocar as políticas públicas como metas prioritárias do orçamento público. Organizou-se um sistema de saúde mental, iniciando com um ousado ato de fechamento do manicômio, com a concomitante implantação de serviços substitutivos e açôes inovadoras, segundo a lógica do território e o princípio de responsabilidade e acessibilidade. A experiência de Santos foi reconhecida, à época, como exemplar pela Organização Pan-Americana de Saúde (Opas) e ainda hoje nos guia como o paradigma do sonho possível de se concretizar.

Contudo, a experiência de Santos e de outros municípios, que, ao longo da década 1990 e nos anos iniciais deste novo século, efetivaram os princípios do SUS na organização de seus sistemas locais de saúde, ainda são honrosas exceções, se olharmos para a realidade dos serviços públicos de saúde, na esmagadora maioria dos municípios brasileiros. Vemos que, entre o preceito constitucional, a Lei Orgânica, as normas e portarias ministeriais e a realidade assistencial, ainda existe uma longa distância, muito maior do que aquela que há entre intenção e gesto. Temos enormes e complexos desafios e problemas a enfrentar e superar, para que a garantia da concretização da saúde como direito de fato possa estar efetivamente presente no cotidiano da vida das pessoas, por meio do acesso universal aos serviços e bens resolutivos, equânimes e de atenção integral.

Um desses grandes desafios refere-se à proposta da mudança do modelo assistencial hegemônico, com as seguintes características mais importantes: 
ênfase na doença por meio de práticas médicas individuais e curativas; visão essencialmente biologista e hospitalocêntrica; investimentos e priorização da especialidade e do desenvolvimento de tecnologias, em detrimento das relações nos processos de trabalho. O SUS caminha para a construção de um novo modelo, que pode ser assim caracterizado: ênfase nas ações básicas de caráter preventivo e de interesse coletivo; fortalecimento do cuidado e da promoção da saúde, orientado por uma concepção da relação saúde-doença como processo social; visão norteada pela interdisciplinaridade (ou transdisciplinaridade, como veremos à frente) e pela intersetorialidade; destaque para as relações nos processos cotidianos de trabalho e na busca da autonomia das pessoas e populações em relação à saúde.

Concordo com os trabalhos de Merhy (2002), Merhy e Franco (2003) e Campos (1994, 1997, 2000), quando ressaltam que o processo de mudança do modelo dimensão técnico-assistencial depende menos das normais gerais e dos processos de regulação do que da mudança nos espaços na micropolítica ${ }^{46}$ das organizaçóes e dos processos de trabalho, no cotidiano da produção da saúde.

É no cenário dos serviços de saúde, com seus diferentes atores (usuários, trabalhadores, gestores), cada qual com seus interesses, projetos e desejos, ora conflitantes, ora coincidentes, que acontecem os encontros, tensões são geradas, reproduz-se ou transforma-se a realidade, produzem-se as relações sociais.

Frisei que o trabalho em saúde é sempre relacional, pois depende do trabalho em ato. $\mathrm{O}$ processo de transformação do modelo assistencial, na perspectiva da promoção e da defesa da vida, acontece nesse cotidiano, nos encontros e nos atos da produção do cuidado.

Franco, Bueno e Merhy (1999: 347) afirmam que a responsabilização clínica e sanitária e a ação resolutiva, com o objetivo de defender a vida das pessoas, somente são possíveis quando se acolhe e se vincula,

Na medida em que, nas práticas de saúde, individual e coletiva, o que buscamos é a produção da responsabilização clínica e sanitária e da intervenção resolutiva, tendo em vista as pessoas, como caminho para defender a vida, reconhecemos que, sem acolher e vincular, não há produção desta responsabilização e nem otimização tecnológica das resolutividades que efetivamente impactam os processos sociais de produção da saúde e da doença.

\footnotetext{
${ }^{46}$ Os autores citados adotam esse conceito na acepção utilizada por Guattari (2005).
} 
Repetindo o que já disse anteriormente: o encontro que produz o cuidado, regido pela alegria e pela beleza, na apropriação e produção de sentidos do território, somente é possível se o usuário acessar o serviço e os recursos de que dispõe para essa produção da vida. E o primeiro verbo que ele deve encontrar sendo conjugado no serviço é acolher. Território, acesso, responsabilização se articulam agora ao acolhimento.

\section{ACOLHIMENTO}

Encontram-se, no Relatório da III Conferência Nacional de Saúde Mental, inúmeras referências ao conceito de acolhimento, dentre as quais destaco, no item "Organização e produção da rede e dos serviços substitutivos":

Os serviços substitutivos devem desenvolver atenção personalizada garantindo relações entre trabalhadores e usuários pautadas no acolhimento, no vínculo e na definição precisa da responsabilidade de cada membro da equipe. A atenção deve incluir açôes dirigidas aos familiares e comprometer-se com a construção dos projetos de inserção social, respeitando as possibilidades individuais e os princípios de cidadania. (SUS, 2002: 38)

E no item "Atenção básica": "Faz-se necessário ainda que a reorganização da Rede de Atenção Integral à Saúde Mental enfatize a Atenção básica, entendendo esta como um conjunto de unidades e açóes articuladas em um território, sob o eixo do acolhimento, vínculo e heterogeneidade" (SUS, 2002: 48).

No dicionário Houaiss (2001), encontram-se os seguintes significados para o verbo 'acolher': 1. oferecer ou obter refúgio, proteção ou conforto físico; 1.1 dar ou receber hospitalidade. 2. ter ou receber (alguém) junto a si. 3. p. ext. prestar cerimônia a; recepcionar. Sua etimologia é de origem latina e proveniente de accolligere, que significa acolher, colher, reunir, apanhar, juntar.

Já para o substantivo 'acolhimento', encontramos no mesmo dicionário: 1. ato ou efeito de acolher; acolhida. 1.1 maneira de receber ou de ser recebido; recepção, consideração. 1.2 abrigo gratuito; hospitalidade. 1.3 local seguro; refúgio, abrigo. 
Nos diferentes significados atribuídos, tanto ao verbo 'acolher', quanto ao substantivo 'acolhimento', há elementos que expressam importantes características do lugar a ser ocupado pelo serviço e pela equipe de saúde, na relação com aquele que busca cuidado.

Todos os que já sofreram alguma dor física ou psíquica intensa sabem o quanto ficamos frágeis, impotentes e dependentes. Nessa hora, o que mais desejamos é um lugar ou alguém que nos "ofereça refúgio, proteção ou conforto físico". Um lugar para "abrigar (-se)", "amparar (-se)". Se for um lugar estranho, novo, que haja pessoas que possam "dar hospitalidade". Que possamos ser recebidos com consideração.

Com certo atrevimento, gostaria de refletir sobre uma situação pessoal de busca de cuidado na saúde. Argumento utilizando um exemplo de Edgar Morin, ${ }^{47}$ sobre a complexidade, no qual ele descreve as características de uma taça de vinho do Porto, vendo em suas substâncias químicas a história do Universo e, ao mesmo tempo, tal combinação só pode ser encontrada em uma determinada região. Acrescentaria a singularidade da experiência de saborear a taça, única e intransferível. Do mesmo modo, uma situação singular, cuja combinação de elementos ocorreu em um determinado lugar, talvez possa contar uma história maior do que a sua singularidade.

Certa ocasião, acometido de uma crise de labirintite, fui atendido, em um pronto-socorro, por uma médica que me conhecia. Ela me cumprimentou, perguntou o que eu estava sentindo, fez exame de fundo de olho, auscultou meu coração e, dez minutos depois de um diálogo entre médico e paciente, ela finalmente me olhou com olhos de quem vê o sujeito e surpreendeu-se, ao me reconhecer: "Nossa! É você! Tudo bem?". A partir daquele instante, deixei de ser um corpo sem identidade. Era uma pessoa conhecida que estava à sua frente. Nos momentos iniciais, senti-me apenas um corpo doente, visto apenas como 'a' dor ou como 'o' sofrimento. Objeto sem fala, sem alma, sobre o qual procedimentos técnicos e tecnológicos iriam incidir. A ela interessava apenas o que o corpo dizia. Era apenas um corpo doente.

Outra ocasião, um amigo que faz sessões semanais de hemodiálise me contava sobre a sua sensação na relação com os profissionais que o atendiam: tratavam-no como alguém que estava vivendo uma espécie de bônus da vida, um corpo com algum tempo de sobrevida, nada mais. Como enfatizei no início deste capítulo, estes são exemplos de relações, nas quais o cuidado

${ }^{47}$ Exemplo extraído de Almeida (2002). 
é produzido como um ato burocrático, prescritivo. $\mathrm{O}$ modelo médico hegemônico se reproduz, centrado na doença e na técnica sobre o corpo. Não há possibilidade de um encontro entre sujeitos, entre subjetividades. Apenas entre o saber médico e seu objeto de estudo e de intervenção.

$\mathrm{Na}$ dor, na fragilidade, no sofrimento psíquico, o que se deseja é ser olhado e escutado por inteiro, como uma pessoa com vida e com história. Ser acolhido integralmente. Assim, a conjugação do verbo 'acolher' e a utilização de seu substantivo 'acolhimento' me parecem indissociáveis, no campo da saúde, do conceito de integralidade, que apenas tangenciarei neste capítulo.

Para ser acolhido, é necessário encontrar uma porta aberta, adentrar o serviço e ser recebido. $\mathrm{O}$ encontro produtor dos atos de cuidar pressupóe um momento de acolhida, de recepção, que considere aquele que busca nossa 'hospitalidade' ${ }^{38} \mathrm{em}$ sua totalidade. Assim como o cuidado, acolher é mais do que um ato - é uma atitude.

Tanto na experiência do Caps Luiz Cerqueira (Goldberg, 1996, 1998; Yasui, 1999), quanto na dos Naps de Santos (Nicácio, 1994), bem como na de muitos outros serviços substitutivos de saúde mental, encontra-se uma atenção, um especial cuidado com esse momento crítico, que é a chegada do usuário ao serviço. Atenção que se revela na organização de fluxos de encaminhamentos ágeis e não burocráticos, na disponibilidade e na abertura em atender à demanda espontânea, no estabelecimento de rotinas diárias de recepção (por exemplo, quem recebe e como recebe) e, fundamentalmente, na construção de um novo lugar. Lugar de ruptura com modelo médico hegemônico ocupado apenas em tentar ouvir os sons do corpo pelo silêncio dos órgãos. Construir um lugar na relação com aquele que busca os cuidados do serviço implica ouvir, fazer falar o sujeito e sua subjetividade, colocar a doença entre parênteses e olhar para a pessoa e a complexidade de sua existência.

Corbisier faz reflexões sobre o trabalho desenvolvido no acolhimento à crise em um serviço de emergência psiquiátrica, que, junto com outros autores, nomeia como a clínica da recepção. Tomo aqui as suas palavras, uma vez que elas traduzem essa perspectiva, esse caminho que estamos a trilhar:

\footnotetext{
${ }^{48}$ Sentidos na palavra obtidos no dicionário Houaiss: 1. ato de hospedar; acolhida de hóspedes; hospedagem 2. qualidade do que é hospitaleiro; boa acolhida. 3. derivação: por extensão de sentido: recepção ou tratamento afável, cortês; amabilidade, gentileza. Como diria o louco profeta Gentileza: "O mundo precisa é de gentileza".
} 
trata-se de ouvir os múltiplos sentidos que os sintomas do sofrimento mental podem revelar:

os sintomas eram frutos de uma desorganização na vida da pessoa como um todo; que tinham conexões com as dores da existência; que mostravam as linhas mais frágeis do esqueleto psíquico; que traduziam, em línguas novas, contornos emocionais pouco ou nada aceitáveis pelas famílias e pelas próprias pessoas; que arregalavam de formas esbugalhadas as entranhas para qualquer um, sem pudor; que rompiam escandalosamente com o bom senso, qualquer senso; que traziam à tona uma ruptura como conhecimento racional das doenças mentais; que, por tudo isso, nos confrontavam com uma necessidade imperiosa de conversar muito com estas pessoas para tentar começar a descobrir por que caminhos mentais andavam. Por onde se tecia a complexa rede de filamentos emocionais que num determinado momento se desfazia precisando ser retecida? (Corbisier, 2000: 60)

O desafio de traduzir esses múltiplos sentidos que os sintomas do sofrer psíquico evidenciam, de urdir essa teia ou, antes, de fiar esses invisíveis fios, remete-me aos encontros que tinha com cada novo usuário que recepcionava no Caps Luiz Cerqueira. Construir esse lugar, rompendo com os modelos hegemônicos, é abrir mão de cegas verdades e certezas absolutas, o que nos deixa, quase sempre, ansiosos, inseguros, na 'corda bamba' das ferramentas provisórias. A cada entrevista, um sutil cerimonial para possibilitar o encontro: troca de olhares, cuidado nas primeiras palavras, atenção nos detalhes dos gestos, nos silêncios. Um encontro com o sujeito e com seu mundo nem sempre é traduzível em palavras. Os mesmos olhares, gestos, silêncios podem pedir a nossa cumplicidade, a nossa ajuda, para se expressarem, para produzirem sentidos: "O que me faz sofrer? Por que a minha alma dói tanto?”.

Recepcionar e acolher são atitudes que pressupõem esse lugar especial de escuta, possuidor de uma plasticidade para se refazer de acordo com a demanda que se apresenta, e possibilitador do encontro como ponto de partida para a construção de um projeto de cuidados, específico e singular para o mundo que cada usuário apresenta. Talvez possa adaptar uma velha máxima da medicina, a qual afirma que "todo bom tratamento começa com um bom diagnóstico", para "todo bom projeto de cuidado começa com um bom acolhimento e uma boa recepção", porque é a partir desse momento inaugural que principia a relação/vínculo entre a equipe cuidadora e o usuário. 
Recepcionar e escutar o usuário são atributos essenciais para uma transformação não apenas da saúde mental. Para Franco, Bueno e Merhy (1999), o acolhimento é uma diretriz operacional para mudança do modelo "tecnoassistencial", que propõe inverter a lógica de organização e funcionamento dos serviços de saúde a partir dos seguintes princípios:

1) Atender a todas as pessoas que procuram os serviços de saúde, garantindo a acessibilidade universal. Assim, o serviço de saúde assume sua função precípua, a de acolher, escutar e dar uma resposta positiva, capaz de resolver os problemas de saúde da população.

2) Reorganizar o processo de trabalho, a fim de que este desloque seu eixo central do médico para uma equipe multiprofissional - equipe de acolhimento -, que se encarrega da escuta do usuário, comprometendo-se a resolver seu problema de saúde.

3) Qualificar a relação trabalhador-usuário, que deve dar-se por parâmetros humanitários, de solidariedade e cidadania. (Franco, Bueno \& Merhy, 1999: 347)

A produção do ato de cuidar se dá no encontro entre o usuário com suas necessidades e o trabalhador da saúde com seu repertório e suas ferramentas. $\mathrm{O}$ acolhimento, para os autores, permite focalizar analiticamente esse processo e possibilita pensar a micropolítica do processo de trabalho e suas implicações no desenho dos modelos de atenção.

Em caminho semelhante, Gastão W. Campos (1997) defende o "vínculo de acolhida" e o ato de "responsabilizar-se a equipe" como diretrizes que deveriam sobredeterminar todo o desenho do modelo assistencial. Ressalta que o termo 'acolhida' deve ser compreendido em um sentido mais amplo do que aquele empregado na prática clínica tradicional, referindo-se tanto a uma abertura dos serviços públicos para a demanda, como para a responsabilização dos problemas de saúde de uma região. Campos (1997: 63) afirma que

o "coeficiente" de acolhida deveria ser avaliado (...) em uma perspectiva dupla: segundo as possibilidades do ACESSO de novos e velhos pacientes ao atendimento, e ainda de acordo com a PLASTICIDADE do Modelo de atenção. Em outras palavras, conforme sua capacidade de mudança, de adaptação de técnicas e de múltiplas combinaçôes de atividades, objetivando sempre dar conta da variedade dos problemas de saúde, da inconstância dos recursos disponíveis e ainda do entrelaçamento da saúde com aspectos socioeconômicos e culturais. (grifos do autor) 
Já o termo 'vínculo' é um elemento essencial para uma prática clínica de qualidade, favorecendo o aumento da eficácia das ações de saúde e introduzindo um controle social realizado pelos usuários no momento mesmo em que os cuidados estão sendo produzidos. Propõe o autor que o vínculo doente/ família não se dê com um único profissional, mas com uma dada equipe localizada em um dado serviço. Ao que acrescenta a ideia do contrato de cuidado, de direitos e deveres do paciente/família e da equipe de saúde, que explicita o projeto terapêutico, em que são considerados os elementos técnicos, as possibilidades de acesso, de intercâmbio usuário/serviço etc.

Essa noção é muito semelhante ao que desenvolvíamos no Caps Luiz Cerqueira. Todo usuário, uma vez admitido no serviço, estabelecia um contrato com a equipe que se responsabilizaria por seu cuidado, no qual se explicitava o projeto terapêutico a ser executado, com a plasticidade de modificar, tanto o contrato quanto o projeto, sempre que surgisse um evento relevante para tal.

Acolher e responsabilizar-se não são importantes conceitos apenas para a produção de cuidado e para a organização dos serviços substitutivos de saúde mental: são instrumentos conceituais centrais para uma proposta de mudança de modelo assistencial na saúde.

Campos ainda salienta que a organização do sistema público, considerando as diretrizes do vínculo e de uma acolhida integral aos problemas de saúde,

será sempre um modelo tendente a instituição de um processo radical de descentralização, de produção de modos heterogêneos de cuidado, que exigiria a presença de serviços e de equipes de trabalhadores com um razoável grau de autonomia e de responsabilidade técnico-profissional-gerencial. Ou seja, o sucesso deste modelo depende de um razoável equilíbrio dialético entre a autonomia e responsabilidade dos trabalhadores de saúde. Conflitos e tensão permanentes, canalizados para soluções criativas, para a superação dos velhos e persistentes impasses dos serviços públicos: ineficácia, burocratização, apropriação privada do espaço público. (Campos, 1997: 64)

Nessa perspectiva, Campos (2000) sugere um método de organização dos serviços públicos de saúde, que nomeia como Método da Roda, para a análise e cogestão de coletivos. Partindo da hipótese de que, nos processos de produção de bens ou serviços, ocorre, de modo simultâneo, a coprodução 
de sujeitos e instituições, esse autor propõe montar sistemas de gestão que tenham como objetivo não apenas a produção de bens e serviços, mas, também, dos sujeitos e dos coletivos que se organizam para tal produção. Esse método vivificou-se na gestão 2001-2004 da Prefeitura de Campinas, da qual Campos foi secretário, com expressivos e importantes resultados, tais como a consolidação das seguintes diretrizes de saúde coletiva:

a descentralização com autonomia, tendo o nível local como o foco principal do sistema; estímulo ao desenvolvimento de sujeitos, na resolução de seus problemas de saúde; a integralidade das ações com mudanças das práticas e integração dos diversos serviços; o trabalho no território vivo; o enfoque de risco na tomada de decisão. (Campinas, 2004)

O Método da Roda radicaliza a ideia no investimento na micropolítica dos serviços de saúde, no cotidiano dos processos de trabalho, como produtores de subjetivação. Neste microuniverso, a equipe de trabalhadores é a responsável pela produção dos encontros e dos atos de cuidado. É ela que acolhe, recebe, responsabiliza.

\section{NOTAS SOBRE A EQUIPE DE SAÚDE MENTAL}

A equipe é o principal instrumento de intervenção/invenção/produção dos cuidados em saúde mental. Trata-se de uma produção que se dá no agenciamento de afetos para produzir vínculos, na negociação de interesses divergentes, na pactuação para um projeto de cuidado, enfim, nas relações que emergem no encontro entre a demanda e o sofrimento do usuário com o trabalhador, sua subjetividade e sua "caixa de ferramentas". ${ }^{49} \mathrm{O}$ usuário em crise que se recusa a ir ao serviço; a família que exige internação de seu membro em um hospital psiquiátrico; o morador de rua que incomoda os vizinhos; o usuário que estabelece uma relação de dependência com o serviço. Exemplos de situações que são desafios cotidianos encontrados pela equipe e nas quais se instaura a tensão permanente entre um modelo hegemônico de cuidados que já se conhece e um outro que se pretende construir. Retomando a citação mencionada linhas antes, o cuidado é a arte do encontro, embora haja tantos desencontros pela vida.

${ }^{49}$ Entendido aqui no sentido utilizado por Merhy (2002) como o conjunto de saberes de que se dispõe para a ação de produção dos atos de saúde. 
Desencontro que se manifesta no modelo psiquiátrico hegemônico que ainda prevalece nas ações de cuidado de muitos serviços, os quais apenas se nomeiam como Caps. Como resposta da equipe a essas situações, tenho ouvido com muita frequência as seguintes frases: - $\mathrm{O}$ usuário não quer vir? Não é mais de nossa responsabilidade então. - A família pede internação. Pois que se interne. Atenda-se a solicitação. - Morador de rua? Isto é problema da assistência social do município. - $\mathrm{O}$ usuário está em crise no serviço? Chama o psiquiatra para medicar! E quando está em crise no meio da rua? Chama-se a polícia. Além das características que já alinhavei sobre esse modelo hegemônico, apontaria uma outra que surge com desanimadora frequência nas ações, especialmente dos profissionais não médicos, que tenho presenciado nos muitos Caps com os quais mantenho contato: são atos norteados por valores e julgamentos morais. Frases como: - Não faça mais isso, fulano. É muito feio! - Quem não se comportar direito não ganha o ovinho de Páscoa! - Quem vai acompanhar os usuários? Eles não podem sair sozinhos! - Que gracinha, nem parece que são doentes mentais! revelam que o usuário é colocado em um lugar de infantilização e a atuação da equipe é no sentido de 'corrigir' e 'educar' os comportamentos. Ouvi, certa vez, um usuário afirmar irritado, a respeito de um Caps que ele frequentava: "- Isto aqui parece uma creche para doido!”. Sobre esse tema, Foucault (1975: 84) afirma que "a loucura encontra-se inserida no sistema de valores e das repressões morais. Ela está encerrada num sistema punitivo onde o louco, minorizado, encontra-se incontestavelmente aparentado com a criança, e onde a loucura, culpabilizada, acha-se originariamente ligada ao erro".

O desencontro que ocorre nessa reprodução de condutas submete o usuário e o trabalhador a um lugar de sujeição, de produção de subjetividades enquadradas, conformadas e bem-comportadas. Produção de afetos tristes. Renúncia à potencialidade criativa, ao desejo, à autonomia. Não há Caps aqui, apenas mais um serviço de saúde mental organizado segundo a mesma lógica hegemônica.

Em um determinado momento da história da Reforma Psiquiátrica, a constituição das equipes multiprofissionais era apontada como um promissor instrumento de mudança. No estado de São Paulo, no início dos anos 80, a Secretaria de Estado da Saúde elaborou um texto denominado "Proposta de Trabalho para equipes multiprofissionais em unidades básicas e ambulatórios de saúde mental," conhecido como a cartilha da Coordenadoria de Saúde Mental, explicitando uma série de sugestōes para a organização do 
trabalho das equipes de saúde mental nas unidades básicas de saúde e no ambulatórios, com uma abordagem bio-psicossocial. $\mathrm{O}$ trabalho em equipe constituía-se em uma espécie de terra prometida, onde afinal se poderia mudar o modelo e exercer uma boa assistência da saúde mental. Proposta, aliás, como assinalei no capítulo 1 , já contida em documentos oficiais desde a década de 1960 .

Entretanto, tivemos - e ainda temos -, para a concretização de uma proposta de trabalho em equipe multiprofissional, diversos problemas que a transformam em um dispositivo burocrático. Uma primeira questão refere-se ao fato de que a reprodução da divisão social do trabalho no campo da saúde gera uma hierarquização das relações, nas quais o saber médico prepondera sobre outros saberes, que cumprem um papel secundário. Essa mesma divisão produz uma compartimentalização de atividades e tarefas com pouca ou nenhuma relação entre si. Por exemplo, no cotidiano dos ambulatórios de saúde mental, que se propõem como espaços de trabalho em equipe multiprofissional, o reflexo dessa divisão se dá com a consulta do psiquiatra como a atividade prioritária e essencial, com agenda repleta, atendimentos de curtíssima duração, visando a uma alta produtividade; depois, há a consulta do psicólogo, geralmente individual e com longa lista de espera; depois os grupos de orientação coordenados pela enfermeira ou pela assistente social; e o grupo de atividades da terapeuta ocupacional. Os encaminhamentos de um profissional para outro, que trabalha na sala ao lado, se efetivam com o preenchimento de uma guia entregue na recepção, que agenda a consulta. Os diversos profissionais que trabalham em um mesmo lugar se reúnem (com dificuldade), uma vez por mês, e discutem questões administrativas. Nos cinco minutos finais, um ou outro caso mais grave merecerá a atenção da parte da equipe que ficou até o final da reunião.

A racionalidade implícita no modelo médico hegemônico determina um modo de organização das práticas de saúde que se caracterizam por atividades curativas, individuais, assistencialistas e especializadas. Pensar em ações preventivas, atenção integral, trabalho em equipe e práticas coletivas de saúde não faz parte dessa racionalidade, que está adequada para uma prática privada regida por uma lógica mercadológica. Nessa lógica, existe apenas sociedade ou parceria regida por interesses comerciais. Uma proposta de trabalho em equipe, apenas imposta como regra normativa, não reconhece os processos cotidianos de trabalho como campos de tensão e de interesses conflitantes entre distintos atores, nem considera que os profissionais que 
atuam foram formados para um mercado privado da saúde e não para a saúde coletiva.

E, por fim, temos problemas com o próprio conceito multidisciplinar, que inspira o termo 'multiprofissional', que entendo, assim como outros autores, ${ }^{50}$ como mero somatório de diferentes campos, que não estabelecem diálogo, não apresentam nenhuma cooperação entre si, mantendo seus limites e fronteiras e olhando desde suas perspectivas e lugares para um mesmo objeto: no nosso campo, a doença mental. Assim, a equipe multiprofissional, por essa caracterização, já está fadada a ser um apenas grupamento de profissionais de distintas áreas que ocupam o mesmo espaço físico.

Conforme apresentei no capítulo anterior, a Reforma Psiquiátrica, ao romper com a visão biológica reducionista e propor a desmontagem dos conceitos basilares da psiquiatria, alinha-se na perspectiva de uma crítica aos fundamentos da racionalidade científica moderna (relação sujeito-objeto, reducionismo, determinismo). Propóe inventar o seu campo teórico-conceitual, estabelecendo um intenso diálogo entre as diferentes disciplinas e conhecimentos que tratam do humano. Produz um borramento entre os limites e fronteiras, constituindo possibilidades diversas para pensar e fazer.

Essa é uma perspectiva semelhante a que Passos e Barros (2000: 76) nomeiam como transdisciplinaridade que "subverte o eixo de sustentação dos campos epistemológicos, graças ao efeito de desestabilização tanto da dicotomia sujeito/objeto quanto da unidade das disciplinas e dos especialismos".

É uma proposta ousada e de alto risco. Pode-se produzir algo disforme, sem contornos, que mais confunde e desorganiza, do que orienta e institui. Um pensamento que corre o risco de nada produzir, visto que pode se perder na indiferença e no relativismo, como se tudo ou nada valesse. É, portanto, um grande desafio, constituir esse saber/fazer nos interstícios dos campos disciplinares ou, como propõem Passos e Barros, empregando um conceito de Deleuze, a que já aludimos, nos intercessores, o que se dá no 'entre', no momento em que ocorre.

${ }^{50}$ Japiassu (1976b) afirma que a démarche multidisciplinar consiste em estudar um objeto sob diferentes ângulos, mas sem que tenha necessariamente havido um acordo prévio sobre os métodos a seguir ou sobre os conceitos a serem utilizados. Tem-se apenas uma justaposição de disciplinas sem fazer aparecer as relações que possam existir entre elas. Nessa mesma linha, Almeida Filho (2000) a descreve como uma justaposição de disciplinas em um único nível, sem cooperação sistemática entre os diversos campos disciplinares. 
Não são apenas diferentes disciplinas que olham para um mesmo objeto. Há que se abrir as fronteiras e fazer circular, transitar conceitos e categorias, transmudar os olhares dos sujeitos, transformar nossos modos de pensar, nos transformarmos nesse processo de construção. Inspirado em Edgar Morin, trata-se do desafio do pensar complexo.

E, no meio de tantos desencontros, como produzir encontros do usuário com a equipe? Como concretizar, nos processos cotidianos de trabalho e de produção de cuidado, essa transdisciplinaridade? O que posso dizer é da experiência no Caps Luiz Cerqueira em realizar um trabalho que se aproximou, e muito, dessa proposta transdisciplinar, e que poderia sintetizar da seguinte forma: o trabalho em equipe é aquele no qual os profissionais adotam uma posição de humildade frente a esse nosso objeto complexo, que é o sofrimento psíquico e o existir. Apenas uma solidária e despojada atitude de diálogo, de muito diálogo, pode começar a contemplar essa complexidade. Isso se reflete na organização dos processos do trabalho que será construído, considerando tudo o que já assinalei sobre território, responsabilização e acolhimento, como uma criação coletiva, de relações horizontais, aspirando à transversalidade ${ }^{51}$ proposta por Guattari, e com uma efetiva participação dos usuários e familiares. A concretização desse projeto implica uma maior responsabilidade de cada profissional, não apenas nas decisões e nas competências para o projeto de cuidados, mas também na gestão do serviço. Acarreta, de outra parte, uma flexibilidade na execução de tarefas distintas e intercambiáveis. É necessário não esquecer e reconhecer que somos atores de uma prática social que tem a potencialidade, por meio dos encontros que ensejamos no cotidiano de nossos serviços, de produzir processos de subjetivação, produzir um modo mais autônomo de viver, de fazer a diferença.

E, por isso mesmo, estamos sempre correndo riscos. Há que estar "sempre atento e forte", ${ }^{52}$ para que nas finas teias do cotidiano não sejamos capturados pela lógica do conformismo, da repetição do mesmo, porque este é um processo que se constrói em um movimento contínuo de desfazimento e fazimento, desconstrução e construção. Desconstruir conceitos e categorias, inventar novas possibilidade semânticas e teóricas, desfazer

51 "A transversalidade é uma dimensão que pretende superar os dois impasses: o de uma pura verticalidade e o de uma simples horizontalidade; ela tende a se realizar quando uma comunicação máxima se efetua entre os diferentes níveis e, sobretudo, nos diferentes sentidos. É o próprio objeto da busca de um grupo sujeito" (Guattari, 1981: 96).

52 Referência à música "Divino maravilhoso", de Caetano Veloso e Gilberto Gil. 
os limites disciplinares e fazer novas produçōes. Repetindo o que já assinalei, trata-se aqui de um agenciamento de afetos para produzir vínculos, negociação de interesses divergentes, pactuação para um projeto de cuidado que se faz nas relações que emergem no encontro entre a demanda e o sofrimento do usuário com a equipe, suas subjetividades e suas "caixas de ferramentas".

\section{PROJETO TERAPÊUTICO INDIVIDUAL E A DIVERSIDADE DE ESTRATÉGIAS DE CUIDADOS}

Em um texto escrito no ano de 1989, afirmava que o trabalho do Caps só era possível porque nos colocávamos no lugar daquele que busca entender que não é uma doença o que está em questão na demanda de quem nos procura, mas sim um sujeito com seu sofrimento, com sua singularidade. É a ele que é destinado o trabalho. O usuário é o centro da atenção. Rompendo com o paradigma psiquiátrico, com o modelo hospitalocêntrico, ou médico-centrado, propus, como Merhy (2002), um modelo usuáriocentrado.

Ao construir os novos serviços, as instituições não são mais unidades de produção de procedimentos médicos ou psicológicos, porém locais de produção de cuidados, de produção de subjetividades mais autônomas e livres, de espaços sociais de convivência, sociabilidade, solidariedade e inclusão social. Lugares para articular o particular, o singular do mundo de cada usuário, com a multiplicidade, com a diversidade de possibilidades de invençôes terapêuticas. E isso significa desenvolver, a cada demanda que se apresenta, a cada usuário que recorre ao serviço, uma complexidade de estratégias que contemplem distintas dimensões do existir, que se concretizam no que tem sido nomeado, no dia a dia de muitos serviços, como Projeto Terapêutico Individual (PTI).

O PTI é, ao mesmo tempo, particular, referido a uma subjetividade específica, mas não é um projeto solitário, isolado, pois se articula, na multiplicidade de suas açôes a outros projetos, com outras subjetividades, com propostas de produção de encontros em diversos espaços com diversos cuidadores. Apenas o diverso e o múltiplo para "dar conta" da complexidade do singular que se apresenta na demanda daqueles que buscam os serviços de saúde mental. 
A construção de um projeto terapêutico individual se reveste de um grande desafio. Inicia-se com a semeadura de um vínculo, no momento crítico de aproximação do usuário ao serviço, de sua recepção, do acolhimento e da escuta de seu mundo, seu modo de viver e de seu entorno (família, trabalho, amigos). A relação de um usuário com o serviço não se dá a priori. Vínculos iniciais são frágeis e demandam uma atenção e um cuidado especial. Um descuido, uma desatenção qualquer, e eles se rompem, se quebram.

Durante esse processo, desenha-se e explicita-se o PTI, uma proposta de um conjunto de ações pactuadas entre diferentes atores: o usuário, seus familiares, integrantes da equipe e profissionais de outros serviços, ativados a partir da necessidade do usuário. Pacto que pressupõe uma negociação a envolver a organização de uma nova rotina, definição de quais ações participar, assunção de responsabilidades e compartilhamento de tarefas entre os diferentes atores. Negociação que pressupõe, também, interesses nem sempre convergentes ou conciliáveis: por vezes, a família quer internar; ou o local de trabalho quer demitir o usuário; ou a escola não o aceita mais; quase sempre, divergências entre os integrantes da equipe sobre a melhor conduta e o melhor projeto; em outras ocasiões, temos a resistência do usuário em comparecer ao serviço ou às atividades propostas. Uma vez estabelecido o PTI, um profissional incumbe-se da tarefa de ser a referência, de responsabilizar-se por sua efetivação, ou seja, responsabiliza-se pela articulação das diferentes açōes dos profissionais, por acompanhar, verificar e avaliar os efeitos das ações no usuário. Ratifica ou propõe mudanças no projeto. Exerce um duplo papel: de cuidador e de administrador das múltiplas ações do PTI.

Como apresentei anteriormente, o menu de atividades de um serviço é um indicador da qualidade das ações. Isso significa não abrir mão de nenhuma ferramenta. Não querendo parecer óbvio demais, os medicamentos tradicionais ou de última geração, exames simples ou complexos e sofisticados devem ser usados, mas com parcimônia, sem transformá-los em fetiches, na justa medida do que realmente são: instrumentos, meios. O mesmo raciocínio vale para qualquer outro recurso terapêutico ou ação de cuidado. Talvez possamos recuperar aqui o sentido da palavra phármakon, que, para os gregos, designava uma substância capaz de operar transformações, podendo causar o bem e o mal, a vida e a morte. Para Platão, no diálogo Fedro, o sentido de remédio ou de veneno não está na substância em si, mas no fato de ser aplicada na hora certa, na dosagem certa e por quem conhece a arte e 
a ciência da cura. Platão aumenta a complexidade desse conceito, ao estabelecer uma analogia entre a medicina e a retórica, afirmando que a linguagem é também um phármakon. Manipulado pelo sofista, é veneno; pelo filósofo, é cura. Para Jacques Derrida (1997), em A Farmácia de Platão, a palavra phármakon é, ao mesmo tempo, veneno e antídoto, cura e morticínio, paradoxo ou ambiguidade, que depende de nossas escolhas. O phármakon não possui uma virtude própria, não se constitui apenas como a substância ativa, contudo, compreende também a pessoa que a administra. O phármakon é uma operação que se situa na relação, no entre, que é parte integrante dos efeitos que ele produz. Phármakon é encontro e, também, é um intercessor.

Voltando ao menu de atividades, quanto maior a diversidade e a quantidade de ferramentas, teremos mais possibilidades de construir projetos de cuidado adequados à complexidade de nosso ofício: medicamentos, atendimentos individuais, em grupo, oficinas expressivas, oficinas de geração de renda, projetos de residência terapêutica, articulação com outros serviços no território e o que mais puder ser inventado e criado. Rotelli, Leonardi e Mauri (2001: 91) afirmam que, se mudamos o objeto, se demolimos as antigas instituições, as novas devem "estar à altura do objeto, que não é mais um objeto em equilíbrio, mas está, por definição (a existência-sofrimento de um corpo em relação ao corpo social), em estado de não equilíbrio: esta é a base da instituição inventada (e nunca dada).

Cada profissional conta com uma caixa de ferramentas, ou seja, o conjunto de saberes e de técnicas de que dispõe para a produção dos atos de cuidado, tal como propóe Merhy (2002). Ao articularmos essa caixa com a proposta da transdisciplinaridade, podemos pensar não apenas nas múltiplas disciplinas ou profissões que dialogam, mas nos encontros que se realizam no cotidiano dos serviços que podem inventar diferentes e diversas ferramentas, como uma ferramentaria que, a partir das ferramentas já conhecidas - martelo, serrote, chave de fenda etc. - cria outras para as situações que vão se apresentando.

No cotidiano do Caps Luiz Cerqueira, organizávamos nossas atividades sempre em cúmplices alianças: um psicólogo e uma terapeuta ocupacional coordenando um grupo de atividades expressivas; um psiquiatra e uma assistente social organizando uma festa; uma enfermeira e um psiquiatra coordenando um grupo de familiares, e muitos outros encontros, por vezes inusitados, que produziam um rico momento de aprender saber e fazer 
junto. Eram alianças que se urdiam, pois cada profissional se despojava de suas certezas e de seu lugar instituído, rompendo com as fronteiras pessoais. Essa disponibilidade potencializava a capacidade de produzir encontros e a criatividade, porque cada qual recorria às outras habilidades e conhecimentos que possuía, aplicando como recurso para a construção de uma nova ferramenta, um intercessor. Um talento para tocar um instrumento musical pode criar um grupo de música e se transformar em uma banda para apresentaçôes e shows; um gosto por cinema, uma ideia na cabeça e uma câmera na mão podem inventar, com usuários, filmes e documentários; uma habilidade para jardinagem e decoração pode se transformar em um trabalho coletivo de organização e embelezamento do espaço da casa.

Pensar a transdiciplinaridade na prática significa pensar nesses intercessores que se apresentam em cada caso, em cada projeto terapêutico, e que nos provocam, nos levam a refletir em torno da utilização das potencialidades dos encontros, para aumentar a caixa de ferramentas e nos transformar nesse processo. Por exemplo, quando dois profissionais de distintas áreas elaboram uma determinada atividade e exploram não apenas as habilidades e competências técnicas de cada um, mas potencializam e investem em outras capacidades para criar, nos interstícios desses dois campos profissionais, criam uma nova ferramenta.

Ao produzir esses encontros, produzimos novas possibilidades de compreensão da loucura, da subjetividade humana, do sofrer psíquico; novas perspectivas de olhar para "aquilo que não faz sentido". Arriscar-se a essa aventura misteriosa que é trabalhar com a loucura, com a dimensão humana, nos provoca a permanecer em constante disponibilidade para perceber detalhes, acolher angústias, estar atentos ao inusitado, ao inesperado. Matérias delicadas que formam a possibilidade da criação de encontros, que constroem as práticas cotidianas de cuidado, que inventam o amor, como diz uma canção de Cazuza.

E, falando em amor e loucura, Guimarães Rosa (1985: 291) escreve:

Porque a cabeça da gente é uma só, e as coisas que há e que estão para haver, são demais de muitas, muito maiores diferentes, e a gente tem de necessitar de aumentar a cabeça, para o total. Todos os sucedidos acontecendo, o sentir forte da gente - o que produz os ventos. Só se pode viver perto de outro, e conhecer outra pessoa sem perigo de ódio, se a gente tem amor. Qualquer amor já é um pouquinho de saúde, um descanso na loucura. 
Toda construção das ações terapêuticas de um PTI é um desafio, pois, no mais das vezes, não sabemos bem direito que tipo de efeito esta ou aquela atividade pode produzir nos nossos usuários. No entanto, só é possível produzir quaisquer efeitos se arriscamos, se ousamos, se damos um passo à frente. Cada usuário demanda da equipe horas de reflexão sobre quais as estratégias mais adequadas. Não existem respostas simples. Objetos complexos demandam respostas complexas, mas não complicadas, rebuscadas, barrocas. Por vezes, açôes simples podem ser respostas complexas. Por exemplo, articular uma vaga em uma pensão para moradia de um usuário, que mantém com sua família conflitos permanentes e irreconciliáveis e o levam a ser internado com frequência, pode ser uma ação simples, mas é uma resposta complexa que impacta em múltiplas dimensões na vida do usuário, de sua família, do serviço, da pensão, da equipe de referência, de outras equipes de saúde da atenção básica. Ou seja, essa ação produz um efeito de criação de uma rede de cuidado e de responsabilização.

A reflexão sobre essa complexidade e a produção de uma diversidade de estratégias leva vários autores a denominar essa produção de cuidados, essa clínica, de maneiras distintas: clínica ampliada (Campos, 2001; Bezerra Jr., 1996), clínica antimanicomial (Lobosque, 1997), clínica do sujeito (Campos, 2003), clínica do sujeito ${ }^{53}$ (Tenório, 2001), clínica transdisciplinar (Passos \& Barros, 2000).

Com suas respectivas diferenças e singularidades, podem-se encontrar alguns elementos comuns em algumas dessas nomeações: buscam desconstruir ou questionar o conceito tradicional de clínica relacionado ao conceito de doença, superando um entendimento biologista e contextualizando o processo saúde-doença como resultante de uma multiplicidade de aspectos sociais, políticos, econômicos, históricos, culturais etc. Multiplicidade que incide e se configura na subjetividade de uma pessoa concreta, singular, que demanda cuidados, cujas estratégias e atos se fazem no encontro norteado por uma ética da autonomia, da singularização e da inclusão social. A elaboração de uma estratégia e de uma produção de atos, considerando a complexidade deste objeto, implica pensar na articulação e no diálogo de distintos saberes e fazeres que transbordem para além dos enquadres terapêuticos tradicionais em alianças e encontros com outros recursos do território.

${ }^{53}$ Aqui o conceito de sujeito refere-se ao sujeito do inconsciente. 


\section{CRIAÇÃO DE UMA REDE INTERSETORIAL DE CUIDADOS}

Como afirmei anteriormente, o processo da Reforma Psiquiátrica não pode se restringir à implantação de um determinado tipo de serviço, sob o risco de reduzir a complexidade desse processo a uma reforma administrativa e tecnocrática. Nesse sentido, retomo a ideia de que o Caps deve ser entendido como uma estratégia de transformação do modelo assistencial, que rompe com o paradigma psiquiátrico tradicional, promovendo uma profunda mudança na organização e na gestão dos processos de trabalho, envolvendo todos os atores na constituição de uma rede de produção de cuidados, estabelecendo alianças com outros setores das políticas públicas e com diferentes segmentos e atores sociais.

Mais uma vez, relembro a portaria n. 336/2002, que aponta a rede de cuidados como característica do Caps: "responsabilizar-se, sob coordenação do gestor local, pela organização da demanda e da rede de cuidados em saúde mental no âmbito do seu território".

Devemos entender a organização dessa rede de cuidados em duas dimensões: a primeira se refere à rede de serviços de saúde existente no território. A própria portaria aponta para essa dimensão, encarregando o Caps de

desempenhar o papel de regulador da porta de entrada da rede assistencial; coordenar as atividades de supervisão de unidades hospitalares psiquiátricas no âmbito do seu território; e supervisionar e capacitar as equipes de atenção básica, serviços e programas de saúde mental no âmbito do seu território.

A equipe do Caps inscreve-se na organização da rede assistencial do sistema local de saúde, ocupando o lugar de referência e, portanto, lugar de permanente diálogo, apoio e intercâmbio para o planejamento, organização, execução e avaliação das açôes de saúde mental.

Por sua vez, a segunda dimensão concerne a uma rede a ser tecida, ativando os diferentes recursos existentes no território que possam ser utilizados, estabelecendo alianças com outros setores e segmentos sociais. Para Saraceno (1999: 101), a inserção do serviço no território possibilita a libertação dos "recursos escondidos" e

o serviço pode contar com vários recursos, dentre eles as próprias pessoas que nele trabalham, os recursos materiais e os chamados recursos escondidos que 
podem ou não pertencer ao sistema sanitário, mas são potencialmente agregáveis e ao mesmo tempo geradores de transformação do estilo de trabalho.

Saraceno usa uma interessante analogia com a história de Robinson Crusoé, que nos faz pensar sobre a relação entre o serviço e o seu entorno. O personagem, ao chegar à ilha, vê apenas as sobras do naufrágio como recursos para a sobrevivência. A ilha lhe é desconhecida, ameaçadora e deserta. Com o passar do tempo, o personagem inicia um processo de aprendizado e de adaptação que lhe desfaz a cegueira de seus saberes precedentes, que não permitem ver nem usar os recursos que, desde sempre, lá estavam: a água, os frutos, os peixes e até a companhia do "selvagem Sexta-Feira". Combinando instrumentos que sobraram de seu barco, vai descobrindo materiais para inventar e criar outros instrumentos, construir seu abrigo, proteger-se. Assim como o personagem da história, o Caps pode estabelecer uma relação de cegueira com os recursos de seu território, ao ignorá-lo e olhar apenas para o 'barco' em que se está. O Caps, como uma estratégia, como uma proposta de construção de uma rede de cuidados, aprende a olhar para o território, buscando ver e usar os recursos que sempre lá estiveram, quer dizer, toda a complexidade da rede de relações e trocas que se pode efetuar com o entorno.

Descobrir e ativar os 'recursos escondidos' e implementar alianças representa mais um grande desafio. De um lado, temos a divisão social do trabalho, à qual me referi antes, que compartimentaliza as políticas públicas, cada qual com suas especificidades, seus campos de domínio de saberes e fazeres. Saber/fazer que pressupóe relações de poder (Foucault, 1979, 1983), interesses e vontades inerentes a cada campo. De outro lado, atores e segmentos sociais que não estão vinculados às ações das políticas públicas e que também têm seus domínios, seus poderes, seus interesses e vontades. O desafio está em negociar, articular e estabelecer alianças capazes de produzir uma força sinérgica para criar soluçôes e respostas aos problemas complexos que se apresentam, buscando superar a fragmentação dos conhecimentos e a separação das ações. Numa palavra, busca-se a intersetorialidade na urdidura da trama dessa rede de cuidados.

O relatório da III Conferência de Saúde Mental destina um item à intersetorialidade:

A formulação da política de saúde mental, orientada pelos princípios da Reforma Psiquiátrica, requer o desenvolvimento de ações integradas e intersetoriais nos campos da Educação, Cultura, Habitação, Assistência Social, Esporte, Tra- 
balho e Lazer e a articulação de parcerias com a Universidade, o Ministério Público e as Organizaçôes Não-Governamentais (ONGs), visando a melhoria da qualidade de vida, a inclusão social e a construção da cidadania da população. No desenvolvimento de trabalhos com a perspectiva da intersetorialidade, destaca-se, ainda, a necessidade de contemplar a singularidade de cada território. (SUS, 2002: 54)

Articular açõos integradas com os campos da "Educação, Cultura, Habitação, Assistência Social, Esporte, Trabalho, Lazer, com a Universidade, o Ministério Público e as Organizações Não-Governamentais (ONGs)" significa construir um processo que envolve um intenso diálogo, o qual pressupõe reconhecer e respeitar as especificidades e as diversidades de cada campo; explicitar os conflitos e os interesses envolvidos, para que se possam negociar e pactuar açóes; unir potências, produzir encontros ao redor dos temas que perpassem por todos esses campos, a saber: a melhoria da qualidade de vida, a inclusão social e a construção da cidadania da população.

É uma dimensão essencialmente política. Trata-se aqui de um convite e de uma provocação que, partindo de um setor (a saúde coletiva de forma mais genérica), inscreve na agenda dos atores dos diferentes campos essa necessidade de construir coletivamente caminhos para a ação, evidenciando a possibilidade real e concreta do reconhecimento e da convivência com a diferença, da articulação dos saberes/fazeres fragmentados e isolados, produzindo uma maior capacidade para enfrentar as situações que nascem da necessidade das pessoas e de seus problemas concretos. Ações que produzam efeitos em todos os atores envolvidos, construindo, assim, sujeitos e coletivos (Campos, 2000).

A intersetorialidade reveste-se de especial importância e de argumento fundamental para pensar o Caps como estratégia e não como um serviço isolado. Atribuir a responsabilidade da organização da rede de cuidados não significa dizer que a totalidade das tarefas deva ser executada pelo serviço. A organização de um Caps que assume isoladamente a responsabilidade de "dar conta" de toda a demanda e complexidade da vida do sujeito é muito semelhante à proposta pretensiosa e autoritária do hospital psiquiátrico. Um Caps, em decorrência, transforma-se em mais uma "instituição total" ${ }^{54} \mathrm{O}$ processo de organização do trabalho deve seguir a lógica do território, entendido aqui, igualmente, como o desafio da intersetorialidade,

${ }^{54}$ Conforme conceito formulado por Erwin Goffman (1974). 
que pode ser considerado como uma espécie de vacina contra a tendência onipotente dos serviços que querem cercar a vida do usuário de todos os lados, tornando-o um usuário-dependente de Caps. Afinal, "há tanta vida lá fora". ${ }^{55}$

Vida que acontece no processo de reapropriação desse mesmo território tantas vezes hostil e interditado ao usuário. Quase sempre o seu espaço de circulação restringe-se ao trajeto da casa ao serviço de saúde mental ou, com frequência, ao hospital. A produção de cuidados significa diversificar a rede de açôes, abrindo para novas possibilidades de encontro por meio da ampliação da rede de circulação e uso dos recursos existentes: a piscina do centro social municipal; cursos e atividades do centro cultural; os artesãos que se dispõem a compartilhar seus conhecimentos; organização de associação de usuários e familiares; alianças com projetos e ações de outros setores visando, por exemplo, à constituição de uma cooperativa de trabalho; açôes junto à Câmara Municipal, para a aprovação de projetos de lei; organização de moradias e/ou residências terapêuticas; realização de eventos culturais. Todo um conjunto de ações que provoque, instigue, convide o território, a cultura, a construir coletivamente novas formas de convivência com a diferença, construir um lugar mais solidário, mais justo, mais equânime. E de lugar em lugar, construir um novo mundo.

Enfim, uma rede possui um valor para múltiplos usos: pode servir para acomodar um corpo cansado que necessita de instantes de repouso; uma rede pode delimitar dois lados de um território e dar contornos para um bom jogo; uma rede pode nos ligar com muitas outras pessoas, para que nos comuniquemos e compartilhemos as nossas emoçóes; pode servir para produzir um cordão de gestos de solidariedade em um difícil momento para alguém; uma rede pode aparar a queda do corpo de um trapezista que ousou um salto mais arriscado; uma rede pode ajudar a criar açôes coletivas de transformação. Entretanto, devemos tomar cuidado, pois uma rede pode ser também uma armadilha, feita para capturar, para aprisionar. Contudo, ainda bem que redes, assim, dificilmente capturam o vento das ideias.

O Caps, que é o principal instrumento de implementação da política nacional de saúde mental, deve ser entendido como uma estratégia de transformação da assistência, produtora de cuidados, regidos pela alegria, pela beleza e pelos bons encontros. Cuidado que se inicia com o acolhimento,

55 Trecho da música "Como uma Onda", de autoria de Lulu Santos e Nelson Mota, que foi utilizada em cartazes de divulgação do Movimento da Luta Antimanicomial. 
agenciado pela equipe, e que se tece em rede em uma apropriação no território e na produção de sentidos que potencializam e transformam a vida.

\section{COTIDIANO E O TEMPO}

O pátio de hospital psiquiátrico é um lugar profundamente triste, de solidão, de abandono. Pode estar repleto de pacientes, mas o que se ouve são apenas o ruído do arrastar dos passos e os gemidos de angústia. E o que se vê são seres que ocupam um mesmo espaço, mas não se comunicam, não se veem. Corpos estirados no chão, sem movimento. O tempo se arrasta, quase se paralisa. Não fosse o ciclo do dia e da alimentação, nada alteraria o quadro. Certa vez, quando trabalhava no Juqueri, depois de muitas discussões e enfrentamentos, colocamos um espelho em uma enfermaria feminina. Quase todas as mulheres se espantavam, ao verem em seu rosto as marcas do tempo: - Nossa, quem é essa velha aí no espelho? Não pode ser! Eu era tão jovem! A imagem do espelho produziu naquelas mulheres um duro reencontro com a dimensão do tempo que a mortificante rotina do hospital destruiu. Goffman (1974) relata que, entre os internados de muitas instituições totais, existe um intenso sentimento de que o tempo passado no estabelecimento é tempo perdido, destruído ou tirado da vida da pessoa. É um sentimento de tempo morto.

Sentimento que pode estar também nas nossas práticas cotidianas de trabalho. José de Souza Martins apresenta as ideias de Henri Lefebvre, destacando que uma das características que demarcam o cotidiano é o tempo linear, capturado pela lógica da acumulação. Tempo determinado pela mediação do valor de troca das mercadorias e do trabalho mercantilizado. A vida cotidiana tornada modo de viver sem estilo, "tempo do homem desencontrado consigo mesmo, que se torna produto de seu produto, transfigurado de sujeito em objeto" (Martins, 2000: 103). Um tempo usurpado, controlado, destituído de sentido. Tempos Modernos, ${ }^{56}$ de gestos repetitivos, determinados pelo fluxo contínuo do modo de produção capitalista que se reproduz na passagem das horas de nossos processos de trabalho. Nesse cotidiano administrado e controlado, qual a governabilidade que o sujeito tem sobre seu tempo?

\footnotetext{
${ }^{56}$ Referência ao filme clássico de 1936, dirigido, produzido e interpretado pelo genial Charles Chaplin.
} 
O mesmo autor, ao citar Agnes Heller, nos aponta um caminho possível para essa questão:

só quem tem necessidades radicais pode querer e fazer a transformação da vida. Essas necessidades ganham sentido na falta de sentido da vida cotidiana. Só pode desejar o impossível aquele para quem a vida cotidiana se tornou insuportável, justamente porque essa vida já não pode ser manipulada. (Martins, 2000: 63-4)

É nesse paradoxo e contradição do nosso cotidiano reificado que talvez se possa encontrar a potência para construir caminhos de mudanças. É da contradição das relaçôes sociais, que pode nascer a força para questionar, desconstruir e destruir os valores e micropoderes que produzem nossa subjetividade mesquinha, conformada, triste e servil. Força para correr riscos, investir e afirmar uma produção da vida e de outros valores. Nosso trabalho de produção de cuidado abrange múltiplas áreas: saúde, educação, trabalho, moradia, lazer e cultura. São importantes áreas do humano, dentro de uma perspectiva de transformação no cotidiano, das relações sociais, operando com conceitos, valores e noções como cidadania, autonomia, solidariedade, inclusão, acolhimento, participação e outros mais. Como declara Martins (2000: 57): "O novo herói da vida é o homem comum imerso no cotidiano. É que no pequeno mundo de todos os dias está também o tempo e o lugar da eficácia das vontades individuais, daquilo que faz a força da sociedade civil, dos movimentos sociais".

Produzir atos de cuidado, montar projetos terapêuticos, negociar alianças são ações nas quais o tempo ganha uma dimensão importante. Não o tempo controlado, tempo fugidio e efêmero, tempo este da máxima aceleração, 'tempo sem tempo' do modo capitalista de produção. Não o breve tempo da consulta médica, da produção de procedimentos, seguindo a lógica "Time is money!". Mas outra relação com o tempo. Tempo para receber e acolher; um tempo para ouvir e ver, e outro para refletir. Um tempo para agir, para se modificar pela ação e voltar a refletir. Um tempo de criação, para afirmar a vida. Uma usuária, certa vez, perguntou angustiada: "- Como faço para ver as horas? Não consigo ver as horas!”. Por mais que lhe mostrássemos o relógio, os números e os ponteiros, ela continuava com a mesma pergunta. Até percebermos que sua dúvida talvez fosse outra. Conseguimos 'ver' as horas? Ver o tempo? Qual sua aparência? De quais matérias são formadas as horas? Como constituir um espaço vital, para que o tempo 
possa seguir um fluxo que não aliene? Como podemos nos apropriar do tempo, para que possamos afinal ver as horas?

Cada música possui notas que se arranjam em combinações harmoniosas no passar do tempo que marcam seu ritmo, com momentos de pausas, de acelerações, com suavidade ou vibração. Pensar na produção de cuidados significa ouvir a melodia e o ritmo da canção entoada (ou latente) de cada um, de quem tomamos a delicada e complexa tarefa de cuidar. Ouvir essa singular combinação de silêncios e sons, na qual o tempo acelera num ritmo alucinante, a loucura é uma "recusa de determinado regime de temporalidade, o protesto em forma de colapso frente ao império da velocidade e a reivindicação de um outro tempo" (Pelbart, 1993: 39). Pedido de uma temporalidade diferenciada, que transforma o cotidiano, que inventa uma canção, que possibilita habitar o tempo e a vida de um outro modo.

Goldberg salienta a importância do cotidiano, ressaltando-o e reconhecendo-o como instância terapêutica, a partir da qual o trabalho do Caps Luiz Cerqueira foi-se estruturando. O autor observa, ainda:

É preciso, portanto - se queremos reconhecer e trabalhar com o cotidiano desses pacientes - abordá-lo como instância construtiva, cuja estrutura de repetição não cessa de organizar mundos de vida, ou de permitir a eles a superação contínua de estados drásticos de dilaceração do aparelho psíquico. Mas cumpre observar desde já que, ao reconhecermos o cotidiano como instância simbólica de reconstrução contínua para o paciente, não poderíamos reduzi-lo a uma espécie de pano de fundo da doença, servindo-nos dele para aferir resultados de estratégias de tratamento. Ainda que uma das contribuições secundárias na consideração do cotidiano possa ser esta, não se pode obliterar que o interesse principal da estratégia terapêutica não é propriamente investigá-lo como "meio" conduzindo a certos "resultados" prefixados, mas conhecê-lo e talvez ampliá-lo como único espaço simbólico que de fato resta a esses pacientes, afluindo, além disso, como uma interface expressiva que lhes permite resgatar-se culturalmente. (Goldberg, 1998: 133)

A microfísica do poder ou a micropolítica do desejo se configuram, se constituem, se afirmam, se reproduzem no território, nos pequenos detalhes e na intimidade dos dramas do cotidiano. É nesse terreno que surge mais um desafio para tal proposta de mudança de modelo: romper com a monotonia, com a repetição sem sentido das coisas do dia a dia; produzir e inventar ações de ruptura, explodir o tempo com significados e sentidos; 
rearranjar a rotina do Caps, criando novos e outros caminhos. Assim, conhecer lugares na cidade por onde nunca se andou; experimentar sensações inéditas de fruição estética (ouvir música clássica, ir a um museu, assistir a uma ópera ou a uma peça de teatro); aprender a cozinhar e a degustar novos sabores; descobrir, no ato de fazer algo novo, habilidades para atividades e para expressão inimagináveis são todos exemplos de dispositivos para ampliar e intensificar modos diversos de estar no mundo. Redescobrir a dimensão do cotidiano como produção criativa da vida é produzir outra temporalidade, resgatar sua relação com o passado e o futuro, potencializar a vontade de fazer história.

A vida cotidiana não está "fora" da história, mas no "centro" do acontecer histórico: é a verdadeira "essência” da substância social. (...) As grandes ações não cotidianas que são contadas nos livros de história partem da vida cotidiana e a ela retornam. Toda grande façanha histórica concreta torna-se particular e histórica precisamente graças a seu posterior efeito na cotidianidade. (Heller, 1989: 20)

Como salienta Heller, os grandes acontecimentos históricos partiram da vida cotidiana e a ela retornam. Nesse sentido, os serviços substitutivos devem produzir, em sua prática cotidiana, os fios que tecem novas redes de ações, constituindo alianças com os movimentos sociais, sendo parte do processo de tornar possível a construção de um novo mundo. 


\section{PLANTADORES DE SONHOS}

\section{a Reforma Psiquiátrica é um processo civilizador}

Impossivel existir sem sonhos.

Paulo Freire

Nos capítulos anteriores, procurei caracterizar esse amplo e diversificado movimento de transformação da assistência em saúde mental, utilizando os mesmos termos adotados por Amarante (2003), que compreende a Reforma Psiquiátrica como um "processo social complexo". Esse autor informa que a palavra 'processo' remete a pensar em algo em permanente movimento, sem um fim predeterminado, nem objetivo último ou ótimo. Acrescentaria que, para o dicionário Houaiss (2001), a palavra significa ação continuada, realização contínua e prolongada de alguma atividade.

Assim, podemos considerar que, desde o final dos anos 70, de modo mais intenso e claro, com as primeiras críticas radicais ao manicômio, ao totalitarismo das instituições psiquiátricas, passando pelos anos $80 \mathrm{com}$ a invenção de novas instituições, de novas formas de produzir o cuidado em saúde mental, afirmando-se como movimento social, consolidando-se nos anos 90 como uma política pública nacional de saúde, temos uma diversidade de ações, que se prolongam neste tempo. Temos um processo.

Processo que não se restringe apenas ao subsetor da saúde mental, porém se amplia para outros setores da saúde. Abrange, implica e estabelece alianças com outros segmentos da sociedade, o que coloca em cena muitos e diferentes atores sociais envolvidos com proposições e interesses que entram em conflito, exigem negociação, superação, mudança. E isso nos leva 
ao segundo termo, 'processo social'. E a estes dois agrupa-se o termo 'complexo', pois

se configura na e pela articulação de várias dimensões que são simultâneas e inter-relacionadas, que envolvem movimentos, atores, conflitos e uma tal transcendência do objeto de conhecimento que nenhum método cognitivo ou teoria podem captar e compreender em sua complexidade e totalidade. (Amarante, 2003: 49)

Abrangência e complexidade de um processo social, o qual Amarante (1999, 2003) caracteriza em quatro dimensōes, que utilizei como eixo deste trabalho. Como já me referi anteriormente, o que diferencia o processo da Reforma Psiquiátrica de outras reformas da psiquiatria é uma característica essencial que imprime na palavra 'reforma' uma tensão paradoxal permanente: a ruptura. Nesse sentido, busquei construir uma conceituação 'forte' da Reforma Psiquiátrica, caracterizando-a como uma radical ruptura com o modelo asilar predominante e como construção de novo paradigma científico, ético e político.

Ao examinar a dimensão epistemológica, evidencio a ruptura com o modelo hegemônico de produção de saberes que fundamentam e autorizam o saber/ fazer psiquiátrico. A partir da reflexão crítica dos conceitos fundantes da ciência, tais como neutralidade e determinismo, procurei estabelecer as relações entre a racionalidade científica moderna e a produção dos conceitos e das práticas da medicina e da Psiquiatria. A análise crítica de diversos outros autores, tais como Boaventura Souza Santos, Edgar Morin, Ilya Prigogine, Isabelle Stengers, aponta que vivemos um momento de transição de paradigmas. Buscando encontrar a verdade definitiva sobre os mistérios da natureza e do homem, a ciência encontra apenas verdades provisórias, limitadas. Procurando encontrar imutabilidade, determinaçôes e simplicidade, encontra instabilidade, caos e complexidade. No lugar do fundamento último do saber, as certezas definitivas, ela encontra apenas possibilidades. No lugar de uma ciência autônoma e independente e de cientistas acima do bem e do mal, encontra a história do homem e a defesa de seus interesses, produzindo saber para legitimar poder. É nesse panorama de transição paradigmática que busquei situar a ruptura epistemológica proposta pela Reforma Psiquiátrica. Para Rotelli, Leonardi e Mauri (2001: 28-30),

o mal obscuro da psiquiatria está em haver separado um objeto fictício, a doença, da existência global complexa e concreta dos pacientes e do corpo social. 
Sobre esta separação artificial se construiu um conjunto de aparatos científicos, legislativos, administrativos (precisamente a instituição), todos referidos à doença (...). O processo de desinstitucionalização torna-se agora reconstrução da complexidade do objeto. A ênfase não é colocada no processo de "cura" mas no projeto de "invenção de saúde" e de "reprodução social do paciente".

Ruptura com o modelo psiquiátrico ou modo asilar, de acordo com Costa-Rosa (2000), baseado no isolamento, na tutela, na disciplinarização e que tem no manicômio uma de suas expressões, porém não a única. Seus conceitos permeiam a prática dos profissionais de saúde que, mesmo nos chamados novos serviços, podem reproduzir a mesma lógica que leva à exclusão.

Ruptura que nasce da invenção de saberes e fazeres que constroem um novo modo de cuidar do sofrimento psíquico. Estamos aqui na dimensão técnico-assistencial, a qual procurei apresentar, por meio de uma cartografia sobre alguns dos conceitos-ferramentas, instrumentos do trabalho cotidiano desses serviços que se constituem de coletivos de profissionais, os quais se responsabilizam pelo acesso e pela demanda de saúde mental de seu território, acolhendo e produzindo estratégias diversificadas de cuidado de saúde e de inclusão, construindo uma ampla rede social.

Processo social complexo, encarnado e concretizado pelas ações de protagonistas, imersos e implicados profundamente com o seu tempo histórico, que ampliaram o campo da Reforma Psiquiátrica, fazendo dela também uma luta política para uma transformação social, em estreita vinculação com a Reforma Sanitária. Conforme também já frisei, a saúde possui um valor universal. É parte integrante das condições mínimas de sobrevivência e, como direito, componente fundamental da democracia e da cidadania. Esta é a dimensão que renomeei como política, retomando o percurso histórico da Reforma Psiquiátrica, desde seu nascimento, no contexto de retomada dos movimentos sociais e da redemocratização do país, até a sua consolidação, com a atual política pública de saúde mental.

Neste capítulo final, abordo a dimensão sociocultural, definida por Amarante $(1999,2003)$ como o conjunto de práticas sociais que visam a transformar o imaginário social relacionado à loucura, alterando as relações entre sociedade e loucura, doença mental e anormalidade. E pretendo fazêlo, apontando para dois aspectos dessa dimensão: o dispositivo utilizado para provocar o processo de transformação, que são as ações culturais e artísticas produzidas por todos os envolvidos no campo - usuários, familiares, 
profissionais, estudantes - e pelos artistas que historicamente têm colocado, em suas obras, referências diretas à loucura. E outro, que se coloca no horizonte dessa dimensão e que articula todas as outras: a utopia de mudar o mundo, a Reforma Psiquiátrica como um processo civilizador.

Esses aspectos não esgotam, sequer contemplam a diversidade e complexidade dessa dimensão. Nesse sentido, o que pretendo é apenas provocar e chamar a atenção para aspectos que focalizam a Reforma Psiquiátrica em em dois aspectos especiais: a da arte e da utopia!

E se o leitor acaso exclamar: Arte! Poesia? "Ouvir estrelas? Certo perdestes o senso!" - responderei, citando Mário Quintana, em seu poema "Utopias": "Se as coisas são inatingíveis... ora! / Não é motivo para não querê-las... / Que tristes os caminhos, se não fora / A mágica presença das estrelas”.

\section{SERÁ ARTE?}

Ao final do II Encontro de Trabalhadores de Saúde Mental, realizado na cidade de Bauru, em dezembro de 1987, que marcou o inicio do Movimento Nacional da Luta Antimanicomial, os participantes realizaram uma pequena passeata pelas ruas da cidade. Era uma festiva celebração, caracterizando o princípio de uma utopia proposta por aquele evento: sonhar uma sociedade sem manicômios.

Naqueles dias quentes de dezembro, deliberou-se o dia 18 de maio como um dia especial: o Dia Nacional da Luta Antimanicomial. Como consequência, no dia 18 de maio de 1988 e nos anos seguintes, em uma crescente e contagiante onda, essa celebração transformou-se no estilo do movimento. Dezenas, por vezes, centenas de pessoas, entre usuários, familiares, profissionais, estudantes, docentes, simpatizantes, ocupam os espaços públicos da cidade, apresentam seus cantos, seus contos, suas danças, suas obras, para todos aqueles que passam e param para assistir. Produz-se uma marca, uma intervenção, no dia a dia da cidade, abrindo um espaço para um olhar diferente sobre esse outro, essa alteridade.

Amarante (2007) relaciona uma infinidade de ações e produções criadas a partir dos serviços de saúde mental ou de associações de usuários e familiares: blocos de Carnaval, programas de rádio e TV, músicas, grupos de teatro, bandas de música etc. Além disso, encontramos expressões cultu- 
rais e artísticas que tomam a questão da loucura e se alinham na perspectiva da Reforma Psiquiátrica. Podemos citar, como exemplos: os documentários Profeta das Águas, de Leopoldo Nunes, sobre o líder religioso Aparecido Galdino Jacintho, e Estamira de Marcos Prado, vencedor de vários prêmios, sobre uma mulher, cujo nome dá titulo ao documentário, que habita o universo da loucura e o 'lixão'. Além do filme Bicho de Sete Cabeças, de Laís Bodansky, sobre a história de Austregésilo Carrano. Isso apenas para ficar no cinema. Já no campo da literatura, pode-se retornar no tempo e encontrar, no século XIX, um texto precioso e clássico sobre a relação entre a loucura e a psiquiatria: O Alienista, de Machado de Assis. No começo do século XX, temos duas obras de Lima Barreto, Diário do Hospicio e Cemitério dos Vivos, retratando o cotidiano do hospício que o autor conheceu de perto. E, nas artes plásticas, pode-se citar como exemplo a obra de Arthur Bispo do Rosário, paciente da Colônia Juliano Moreira, no Rio de Janeiro: buscando produzir um sentido para sua existência (afirmava que recebeu a missão de recriar o universo para apresentar a Deus, no dia do Juízo Final), produziu uma obra que estabelece um diálogo com o universo das artes, especialmente com os trabalhos de Marcel Duchamp. Morreu sozinho, entre seus objetos, no quarto de um hospital psiquiátrico, sem sequer imaginar que seria considerado um grande artista plástico.

Do cinema às artes plásticas, produção reconhecida e legitimada pelo mundo e pelo mercado oficial da arte ou apenas produção estética e expressiva de singularidades. São obras que convidam, provocam, incitam quem toma contato e se dispõe a olhar de outro modo, não apenas para a experiência da loucura, mas para a diferença, a alteridade. Os serviços de saúde mental têm uma potencialidade estratégica vital: abrir-se para o mundo. Plagiando novamente a música já citada, neste trabalho: afinal, "há tanta vida lá fora!". Não há possibilidade de diálogo sem visibilidade, com produções armazenadas em armários empoeirados ou desqualificadas como "atividade para passar (matar?) o tempo”. Há um 'fora' a ser conquistado. Apropriar-se dos espaços interditados da cidade, mostrar a face outrora oculta. Nesse sentido, o Dia Luta Antimanicomial, a Parada do Orgulho Louco e outros eventos similares são celebrações de encontros, de diálogos possíveis e improváveis.

Olhar e reconhecer. É esse reconhecimento do outro como diferente que possibilita a emergência de um diálogo. Se, para Foucault (1978), a psiquiatria é monólogo da razão sobre a loucura, as produções culturais e 
artísticas dos atores sociais da Reforma Psiquiátrica desenham um diálogo possível. O mundo fechado, hermético, delirante da loucura, habitado pelos fantasmas de uma infinda solidão geradora de um caos, pode se transformar, pela criação, pela expressão, em um mundo que outros podem acessar, compartilhar, estabelecer trocas, conversas. Estamos próximos ao registro da arte? Essas produções e eventos antecipam, por entre os densos véus da rotina cotidiana, novas perspectivas, novos mundos. Tornarão as coisas mais belas?

Nos serviços de saúde mental, tais produções têm um espaço privilegiado para acontecer: são as oficinas terapêuticas, importantes instrumentos de produção de cuidado e que têm sido amplamente adotadas nos novos serviços substitutivos. Nesses espaços se desenvolvem atividades, artísticas e artesanais, que podem privilegiar tanto a expressão, quanto o aprendizado de alguma habilidade (marcenaria, papel reciclado etc.) ou privilegiar a possibilidade de uma circulação social.

As oficinas têm sido objetos de reflexão de diversos trabalhos (Araújo Lima, 1997; Rauter, 2000; Galleti, 2001; Costa \& Figueiredo, 2004, dentre outros). Embora a utilização de atividades esteja marcada historicamente com o asilo e com as estratégias de tratamento moral, na Reforma Psiquiátrica, no interior dos serviços substitutivos, ganhará uma dimensão radicalmente distinta de sua origem como ocupação do tempo ocioso.

Arte e trabalho são duas complexas categorias centrais, ao se refletir sobre as oficinas. Ambas têm uma função vital para o processo de humanização: a inserção no mundo da cultura. Ao criarem produtos, que podem assumir a forma de bens e serviços, estão gerando valor de uso e de troca, estão gerando valor social. Esse valor social produz a riqueza de uma nação, como se sabe, desde Adam Smith. ${ }^{57}$ É o trabalho do homem que gera a produção material da vida.

Porém, há dimensões subjetivas importantes a se destacar. Há produção de vida. Não se produz somente objetos de consumo, produzem-se relações entre indivíduos, produzem-se relações sociais. Relações marcadas pela alienaçãao, capturadas pelos processos sociais do modo de produção capitalista, mas potencialmente produtoras também de rupturas, de resistências, de lutas sociais. Deleuze e Guattari (1976) destacam essa relação

${ }^{57}$ Adam Smith (1723-1790), autor do livro A Riqueza das Naçôes (1988), considerado por Engels o primeiro economista a reconhecer o trabalho como fonte de riqueza. 
entre trabalho, capitalismo, subjetividade, desejo e produção de vida. Para os autores, o desejo é produtor não apenas de fantasias, mas de mundos.

Nessa perspectiva, Rauter (2000: 269-70) salienta que

as oficinas serão terapêuticas ou funcionarão como vetores de existencialização caso consigam estabelecer outras e melhores conexões que as habitualmente existentes entre produção desejante e produção da vida material. Caso consigam conectar-se com o plano de imanência da vida, o mesmo plano com base no qual são engendradas a arte, a política e o amor.

A palavra 'oficina', segundo o dicionário Aurélio, significa "lugar em que se verificam grandes transformaçôes". Talvez essa definição nos traga o essencial daquilo que se objetiva: possibilitar "grandes transformaçôes". Trata-se de construir um espaço de acolhimento ao sofrimento psíquico; de possibilitar a 're-significação' e construção de sentidos existenciais; de produção de uma subjetividade talvez menos oprimida; de circulação e de reconquista dos espaços sociais; de transformação da qualidade de vida.

Mais do que uma atividade de caráter técnico, essa proposta impóe-se como uma necessidade e uma exigência ética (Saraceno, 1996). Implica mais do que reinserir ou reabilitar por meio de uma técnica inovadora. Significa assumir uma responsabilidade sobre o ato de cuidar, que tem consequências de ordem política, social, cultural etc. Ao se assumir a perspectiva da complexidade do existir humano, o sofrimento se impõe com suas múltiplas facetas. É impossível separar o surto psicótico do Sr. José das suas condições de vida e de seus familiares; das condições históricas que fizeram da internação, dispositivo de exclusão e invalidação social; da cultura que estigmatiza e segrega. Tratar um surto é muito mais do que ministrar remédios e atividades. É pensar em como modificar a vida do Sr. José. As oficinas podem se constituir em um importante caminho para essa transformação.

É nessa perspectiva que entendo o trabalho com as oficinas terapêuticas. As oficinas não são um fim. São apenas trilhas, veredas. São possibilidades de construção de novos territórios existenciais, a partir de um encontro com alguém e da produção de um algo. Alguém que ocupe esse lugar de acolhimento, de respeito à singularidade, de escuta, por vezes de incentivo, por vezes de intervenção na relação. Um lugar de suporte de uma relação que aposta no bom encontro, na provocação, na criação. É um algo produzido que é muito mais do que a concretude do objeto. É um algo que 
condensa relações de troca, marcas subjetivas, afetos. Um algo que produz linguagem. Convida ao diálogo, convida a uma reinvenção. Trata-se de um compromisso com a construção e a produção de uma subjetividade aberta à alteridade, atenta ao que propicia a criação e potencializa os processos de transformação do cotidiano (Araújo Lima, 2004).

O caráter processual desse dispositivo de cuidado alinha-se em uma perspectiva com o campo da estética.

Com a arte aprendemos que as formas constituídas são sempre provisórias e finitas, datadas e inscritas no tempo, e a todo momento novas formas podem ser criadas. Se há um impedimento para esta criação, é este impedimento que deve ser tratado para que o processo de criação possa fluir, instalando um estado de acolhimento do estranho que liberta a potência criadora da vida. (Araújo Lima, 2004: 78)

Para Araújo Lima, tal estado de criação permanente não se instaura somente pela criação de uma obra de arte, mas através de qualquer criação objetiva ou subjetiva. Assim, a arte ocupa aqui o lugar de paradigma, como aponta Guattari (1992), como uma dimensão intrínseca a toda forma de produção e atividade humana: transformar a natureza, transformar o mundo em que se vive, criar a própria existência, criar-se a si mesmo, num processo autopoiético.

Arthur Bispo do Rosário, Emgydio, Estamira, Estela do Patrocínio encontraram um caminho para escapar de morte, escapar de sucumbir à velocidade infinita da angústia. Recontaram suas histórias, criando objetos, palavras, textos, cores. Recriaram em torno um mundo que não isola, mas estabelece com o fora um diálogo, por vezes não inteligível, por vezes sublime.

Nesse sentido, o encontro com alguém na oficina ou ateliers e a produção/criação de um algo a partir desse encontro pode produzir uma saída para o aprisionamento. Criar um mundo no qual se possa habitar precariamente, provisoriamente, porém que dialogue, produza sentidos, linguagem. 'Re-signifique'e organize essa vivência do sem sentido, da angústia, do aprisionamento terrorífico no corpo despedaçado. Habitar uma casa aberta, com portas e janelas.

A sabedoria da vida está neste interjogo constante entre deixar-se penetrar pelas formas culturais já constituídas e deixar-se fecundar pelo estranho que nos 
habita; da articulação entre esses dois movimentos surge a criação de novas formas. Nem fechar-se numa subjetividade enclausurada autônoma, que não se abre a nenhuma novidade, nem perder-se no que é exterior sem conseguir construir um mínimo de interioridade. (Araújo Lima, 1997: 176-7)

Para Araújo Lima, a clínica de psicóticos, a clínica de terapia ocupacional - e acrescentaria, o uso das atividades expressivas de um modo geral - deveriam orientar-se no interior de um campo balizado pelas forças da arte e da cultura, em um movimento incessante de constituição sempre precária das subjetividades. Movimento que produz e faz surgir linhas de fuga, transformação das formas vigentes, a criação do novo, a arte.

A oficina ou qualquer outro dispositivo que favoreça a criação pode favorecer a construção desse lugar, dessa morada, desse habitat. Construção que implica aquele que sustenta esse processo com sua subjetividade, com seu corpo.

Nessa perspectiva, somos aprendizes de um fazer/aprender. Aprender saberes e fazeres que se constroem no contato com o sofrimento do usuário, com as suas condiçôes de vida e de existência. Contato difícil, que revela as duras dimensões desse existir. Uma usuária gostou de uma visita ao aeroporto, porque a deixaram entrar. Sua vivência e percepção dos espaços urbanos era a de uma constante interdição. $\mathrm{O}$ usuário que, com sua aposentadoria, é arrimo da família, mas não pode sequer tocar no seu dinheiro; usuários que dormem no chão de uma edícula, no fundo da casa, e somente entram para realizar as refeições; a família que solicita internação toda vez que o usuário expressa algo de sua subjetividade. E sempre há o assombro, a dúvida que arrebata ao ouvir o delírio, ao sentir o olhar que atravessa e não nota a presença, ao entrar em contato com esse estranho modo de viver, de sentir, de tentar habitar o mundo. De que se trata? Como dialogar? Em decorrência, a oficina é um caminho que descortina um universo de possibilidade de intervenção e invenção e aponta para a complexidade que é o cuidar.

O poema "Traduzir-se" de Ferreira Gullar (s. d.) talvez possa nos auxiliar a pensar que uma parte desse nosso trabalho é como mergulhar em um universo diferente, que exige de nós uma tradução: "Uma parte de mim é todo mundo / Outra parte é ninguém, fundo sem fundo / Uma parte de mim é multidão / Outra parte estranheza e solidão / Uma parte de mim pesa, pondera / Outra parte delira / Uma parte de mim almoça e janta / Outra parte se espanta / Uma parte de mim é permanente / Outra parte se sabe de 
repente / Uma parte de mim é só vertigem / Outra parte linguagem / Traduzir uma parte na outra parte / Que é uma questão de vida e morte / Será arte?".

Esse contato vivo com tal universo de dramas da existência humana questiona a doença mental como categoria central do modelo psiquiátrico hegemônico e nos provoca a refletir criticamente sobre os recursos teóricos e técnicos que possuímos, levando-nos a buscar novas possibilidades, a inventar novos recursos. Nas oficinas e ateliers, busca-se, também, pensar as atividades em uma lógica de produção de cuidado que se oriente pelos problemas e pelas necessidades dos usuários, procurando acolher seu sofrimento, estabelecer estratégias para aumentar seu poder contratual, potencializar sua autonomia, melhorar a sua qualidade de vida.

Uma boa conversa à sombra de uma árvore ou uma caminhada pela cidade; ofertar uma atividade expressiva e descobrir potencialidades criativas; resgatar histórias de vida ao se preparar um bolo; apropriar-se do território, visitando locais e espaços da cidade; ajudar um usuário a organizar uma festa em sua casa; acompanhar um usuário a uma loja para comprar um rádio; pensar alternativas para moradia, projetos de geração de renda, projetos de inclusão social. Trata-se de um encontro produtor de vida. É estimulante ouvir de um usuário que, pela primeira vez, depois de meses de convite, participa da oficina e, ao final, nos olha e diz: "Semana que vem eu volto". Ou de outro, que não se comunicava com ninguém e, certo dia, passa a frequentar a oficina e começa a falar sobre sua vida, sobre sua história. Ou, ainda, aquela usuária, descuidada da aparência, que faz questão de nos dizer que naquele dia tomou banho e se arrumou para vir à oficina. São todos exemplos do cotidiano, de uma produção de cuidado feita de detalhes, de simples gestos que podem transformar uma vida, possibilitar ao usuário habitar o mundo, habitar seu tempo.

É na rotina dos encontros que questôes cruciais da vida de cada um vão sendo pensadas, discutidas, diversificando-se as estratégias de cuidado. Os projetos terapêuticos ampliam-se para o trabalho, moradia, lazer, ou seja, tornam-se cada vez mais projetos de vida.

Trata-se do exercício de uma diversidade de possibilidades de invenção de cuidados que se produzem a partir da construção de um lugar que olha e escuta o sofrimento psíquico como um objeto complexo, como uma dimensão do existir humano. Lugar da ousadia do criar, de correr riscos, do ir 
além. Lugar ético, de ruptura e desvios das práticas hegemônicas, de compromisso com a transformação, que olha para esse existir no futuro, sonhando com mudanças.

\section{UM OUTRO LUGAR PARA A LOUCURA?}

Para finalizar, gostaria de abordar outro aspecto da dimensão sociocultural. É uma dimensão que se refere à construção de um outro lugar social para a loucura em nossa cultura (Birman, 1992). E este não deve ser um lócus indulgente para a diferença. Um lugar no qual se suporta o louco, mas sem alterar as relações sociais. Indulgência cujo sentido remete a suportar e perdoar o erro alheio, absolvendo sua culpa. No entanto, prevalece a percepção de que houve erro, houve culpa. Perdoa-se em um gesto caridoso, que mantém tudo no mesmo lugar. Gesto condescendente com a incapacidade, o defeito, a ausência de obra. Transformar a relação da sociedade com a loucura é convidar a sociedade a refletir e provocá-la a transformar a sua relação com a diferença, com o estranho, com o estrangeiro. Mudar sua relação com essa alteridade não enquadrável, que escapa à racionalidade. Não há como conceber a criação desse lócus para a loucura, sem uma transformação social.

Os desafios decorrentes dessa dimensão são do tamanho das utopias que os militantes das Reformas Sanitária e Psiquiátrica, assim como sonhadores em geral aspiram para a sociedade. Nessa dimensão, constroem-se as ações e práticas mais audaciosas e pretensiosas e, por isso mesmo, estão em consonância com outros campos que também almejam profundas mudanças. Paulo Freire destaca a contribuição da prática educacional à luta política para a transformação da sociedade. "A educação consegue dar às pessoas maior clareza para 'lerem o mundo', e essa clareza abre a possibilidade de intervenção política. É essa clareza que lançará um desafio ao fatalismo neoliberal" (Freire, 2001: 36).

Fatalismo conformista de um pensamento neoliberal que proclama o desaparecimento das ideologias e o surgimento de uma nova história, sem interesses antagônicos, nem luta de classes, produto de uma economia globalizada, massificante e massificada, na qual todas as relações são regidas pela lógica regulatória do mercado. Fatalismo que, por isso, nega e destrói os sonhos e as utopias. A utopia é uma necessidade fundamental do ser humano, pois 
não há amanhã sem projeto, sem sonho, sem utopia, sem esperança, sem o trabalho de criação e desenvolvimento de possibilidades que viabilizem a sua concretização. É neste sentido que tenho dito em diferentes ocasiōes que sou esperançoso não por teimosia, mas por imperativo existencial. (Freire, 2001: 85-6)

Imperativo que faz compreender a história como possibilidade, como projeto da construção do amanhã (Freire, 1992). Utopia aqui não é modelo abstrato e imaginário de sociedade ideal, justa e generosa, porém impraticável, irrealizável, tampouco desejos, ideias e crenças que os seres humanos constroem e que aguardam a sua realização para um futuro distante. As utopias, como salienta Ernst Bloch (2005), formam-se dos sonhos de olhos abertos, sonhos diurnos, e têm como princípio básico a esperança. São da ordem dos projetos alternativos de organização social capazes de indicar potencialidades realizáveis e concretas, contribuindo dessa maneira para a transformação da sociedade. Sua realização se constrói no presente, nos gestos e nas ações cotidianas. São valores marcados pelo seu tempo histórico que os inspiram e, por isso, nunca completamente formulados. O Movimento Instituinte a nomeia como "utopia ativa" e "inclui como aspectos privilegiados a autoanálise e autogestão, ou seja, a Democracia Direta ao mesmo tempo como meio e como fim do processo". ${ }^{58}$

São dessas matérias primas de sonhos diurnos e de utopias ativas e possíveis que se concretizam, no cotidiano, que se formam as ações da dimensão sociocultural.

\section{NOTAS SOBRE BARBÁRIE E CIVILIZAÇÃO}

A Reforma Psiquiátrica, como já afirmei, não pode ser confundida com uma mudança nos serviços de saúde mental, quer dizer, uma modificação na organização institucional das formas de cuidado ou dos processos de trabalho. Ela é muito mais ampla e complexa. Refere-se à ousadia de inventar um novo modo de cuidar do sofrimento humano, por meio da criação de espaços de produção de relações sociais pautadas por princípios e valores que buscam reinventar a sociedade, constituindo um novo lugar para o louco. Isso implica transformar as mentalidades, os hábitos e costumes

${ }^{58}$ Conforme glossário da Fundação Gregório Baremblint. Disponível em: <www.fgbbh.com.br/ glossario.htm>. Acesso em: 3 out. 2005. 
cotidianos intolerantes em relação ao diferente, buscando constituir uma ética de respeito à diferença.

Benilton Bezerra Júnior (1992: 113) assim se expressa, quanto ao processo da Reforma Psiquiátrica:

Trata-se de não apenas de desfazer o aparato e a cultura manicomiais ainda hegemônicas no cenário psiquiátrico, mas, sobretudo, construir uma nova maneira de a sociedade lidar com a loucura. A desconstrução do manicômio implica necessariamente reinventar não só a psiquiatria, mas - no limite - a própria sociedade em que vivemos.

Como assinalei, o II Congresso de Trabalhadores de Saúde Mental, realizado na cidade de Bauru, no ano de 1987, que deu início ao Movimento Nacional da Luta Antimanicomial, destacava não somente a loucura em seu âmbito sociocultural, mas apontava também para a necessidade de se repensar as relações sociais e sonhar uma utopia expressa no lema "Por uma sociedade sem manicômios". Vale ressaltar, novamente, que o manicômio é tomado aqui como a expressão dos mecanismos de opressão de nossa sociedade. São muitos os "manicômios" que permeiam a nossa vida e que se manifestam de diferentes formas: nas instituiçôes que abrigam crianças; nos cárceres; nos atos sutis ou explícitos de discriminação e violência contra negros, homossexuais, índios, mulheres; e nos atos cotidianos que revelam intolerância contra o outro que é diferente, estranho. A luta política proposta pelo Movimento da Luta Antimanicomial, partindo da luta pelos direitos de cidadania aos loucos, incorporava naquele momento histórico de construção da Carta Constitucional a luta pelos direitos de todos trabalhadores à saúde, à educação, à habitação, à justiça, a melhores condições de vida.

Se, para Paulo Freire, a educação deve ser entendida como prática da liberdade, então, talvez possamos pensar a Reforma Psiquiátrica como promoção e produção da liberdade, como defesa radical da vida (Campos, 1994). Uma defesa impregnada de valores que almejam a transformação social. Trata-se, enfim, de processo social complexo que engendra um processo civilizador.

Vale aqui esclarecer que, ao aludir a "processo civilizador" não estou tomando como princípio o fato de existir uma civilização, ou uma cultura, superior a outra, nem me referindo a um processo de imposição de produ- 
tos culturais de uma economia mais desenvolvida sobre outra menos desenvolvida. Esse conceito de civilização que, grosso modo, se confunde com o de modernidade, surgiu para diferenciar a sociedade europeia, branca, masculina, cristã, dos povos do recém-descoberto "Novo Mundo". Nasceu para construir uma identidade em oposição ao estrangeiro, ao diferente, ao bárbaro, ao outro. Essa oposição, que apresenta uma grande ambiguidade, é tema de intenso debate, especialmente após os acontecimentos de 11 de setembro de 2001.

Não pretendo me aprofundar nesse debate, ${ }^{59}$ contudo, gostaria de lembrar as duas grandes guerras mundiais, as diversas guerras étnicas e separatistas, os vários genocídios e outros inúmeros fatos, para ficar apenas no século XX. Eles demonstram que encontramos atos bárbaros nas sociedades civilizadas, especialmente as que chamamos de modernas, cometidos em nome de sua própria defesa, muitas vezes com o "refinamento nos modos" e a "alta tecnologia". Os campos de extermínio da Alemanha nazista foram respostas "racionais" e "tecnológicas" a uma necessidade: o modo mais eficiente e eficaz de eliminação, uma mórbida linha de produção. Nesse sentido, o projeto iluminista de uma evolução civilizadora rumo à liberdade, à felicidade, engendrou, também, barbárie. Assim, uma dúvida pode ser colocada: quem é bárbaro e quem é civilizado?

Wolf (2004) busca responder a essa questão, analisando três diferentes sentidos do binômio civilização/barbárie: a primeira considera a civilização como um processo progressivo, no qual os povos são libertados dos costumes grosseiros e rudimentares de sociedades tradicionais e fechadas, para se 'civilizar', isto é, para abrir-se em uma sociedade mais complexa e urbanizada, permeada por costumes e modos polidos, elegantes, refinados. Norberto Elias (1993) descreve como, entre os séculos XI e XIX, se desenvolveu essa modelagem da sensibilidade e do comportamento humanos. Bárbaros serão aqueles que se comportam como brutos, grosseiros e desconhecem as boas maneiras. Uma segunda visão diz respeito à civilização como as ciências, as letras e as artes, como o patrimônio mais elevado de uma sociedade. Não propriamente toda a cultura, mas sua parte mais especulativa, contemplativa, espiritual. Aqui, bárbaros serão todos aqueles insensíveis ao saber ou à beleza pura. E, por fim, um terceiro sentido que designa tudo aquilo que nos costumes pressupóe o respeito pelo outro, assistência,

${ }^{59} \mathrm{O}$ conjunto de textos encontrados no livro Civilização e Barbárie (2004), organizado por Adauto Novaes, é uma boa fonte de consulta para diferentes aspectos desse debate atual. 
cooperação, compaixão, conciliação e pacificação das relações. Aqui, barbárie está relacionada a tudo o que supõe uma violência vista como primitiva ou arcaica, a uma luta impiedosa pela vida. Representa a perda de qualquer sentimento humanitário.

Após buscar os pontos comuns a esses três sentidos, Elias analisa duas posições teóricas que, por um lado, admitem um sentido etnocêntrico, uniformizador e expansionista para o conceito de civilização, quer dizer, civilizados "somos nós", bárbaros "são os outros". Por outro lado, uma posição relativista, que afirma ser impossível declarar qual povo é mais civilizado do que outro, o que nega qualquer valor humano como universal.

Já Wolf procura apresentar uma posição alternativa, buscando exatamente esse valor universal. Para ele, bárbara é toda cultura que não disponha, em seu interior, de possibilidades que lhe permitam admitir, assimilar ou reconhecer uma outra. E acrescenta:

Conseqüentemente, diremos que uma cultura específica é "civilizada" quando, independentemente da riqueza ou da pobreza de sua cultura científica, de seu nível de desenvolvimento técnico, ou da sofisticação de seus costumes, ela tolera em seu seio uma diversidade de crenças ou práticas (excluindo-se, evidentemente, práticas bárbaras). Uma cultura civilizada é sempre virtualmente mestiça. (Wolf, 2004: 41-2)

Bárbaros são aqueles que acreditam que sua cultura é a única forma de humanidade possível, aqueles que são incapazes de pensar no uno e no múltiplo. São incapazes de conviver com a alteridade, com o estrangeiro, com o outro. Portanto, existem práticas ou culturas bárbaras e civilizadas.

É nessa perspectiva que penso no processo civilizador: como movimento que busca construir essa sociedade mestiça, marcada pelo diálogo, pela convivência e por um profundo respeito às diferenças. Kehl (2004: 102) complementa:

Tolerar o estranho não significa apenas permitir que ele exista em algum lugar, longe de nós. Não significa apenas suportar que ele ocupe a periferia de um mundo no qual nós, modernos civilizados, supomos ocupar o centro. Abrigar e tolerar o estranho é permitir que ele nos desestabilize permanentemente, deslocando nossas certezas, borrando as fronteiras de nossa suposta identidade, oferecendo traços identificatórios que frustram o outro projeto moderno, de unicidade, e individualidade. Tolerar o estranho é tolerar também a incerteza que ele traz. 
Nesse sentido, penso aqui na sociedade que desejo para legar às gerações futuras. Nos valores éticos que sonho um dia se incorporarem ao cotidiano das pessoas. Sonho e desejo, igualmente, que os bens econômicos, culturais e científicos possam estar à disposição e serem compartilhados por todos que fazem parte da sociedade que os produziram.

\title{
AS REFORMAS E O PROCESSO CIVILIZATÓRIO
}

No material de divulgação da $12^{a}$ Conferência Nacional de Saúde, podem ser lidas as seguintes palavras de Sergio Arouca:

\begin{abstract}
A Reforma Sanitária não é um projeto técnico-gerencial, administrativo e técnicocientífico; o Projeto da Reforma Sanitária é também o da civilização humana, é um projeto civilizatório, que, para se organizar, precisa ter dentro dele valores que nunca vamos perder, pois o que queremos para a Saúde, queremos para a sociedade brasileira.
\end{abstract}

Ao me referir aos princípios da Reforma Sanitária, compartilhados pela Reforma Psiquiátrica - que são a universalidade, acessibilidade, igualdade, equidade, integralidade, descentralização, municipalização, intersertorialidade e controle social -, estou aludindo não apenas a princípios e diretrizes de um sistema gerencial, técnico-assistencial que organizam um sistema de produção de cuidados de saúde.

Estão aí implícitos valores que enfocam o projeto de uma sociedade com justiça social, com liberdade, igualdade e que todos os cidadãos possam ter acesso, na medida de suas necessidades e de maneira integral, aos bens, serviços e às açôes de promoção de saúde, entendida em seus múltiplos determinantes sociais. Isso implica acesso não apenas à especificidade da saúde, mas também a uma retistribuição justa dos bens e riquezas produzidas pela sociedade, por meio de políticas sociais e econômicas. Projeto que acarreta, também, uma ativa participação da comunidade na gestão e no controle. São princípios e valores que tensionam cotidianamente as relações sociais produtoras de desigualdades, de iniquidade, de heteronomias, de injustiça, de uma quase barbárie.

Valores que possuem a consistência concreta de atos e gestos cotidianos que podem fazer a diferença na vida daqueles que tomamos o encargo e a responsabilidade de cuidar. Por exemplo, atos de generosidade, de hospitalidade, 
de respeito à diferença. Estes são antônimos de avareza e hostilidade ao outro, valores tão cultivados pelo estilo de levar a vida regido pela busca frenética de acumulação e de competitividade. Busca, também, de uma autossuficiência que Birman aponta como característica do modelo de subjetivação contemporâneo, promovido pela cultura do narcisismo e do espetáculo. De acordo com o autor:

A auto-suficiência, como principio, implica uma hierarquia de base, segundo a qual alguém pode afirmar que pode prescindir dos outros, pois se bastaria. $\mathrm{O}$ que significa dizer que um tal sujeito se coloca em uma posição de superioridade ontológica em relação aos demais, tendo seu valor incrementado. Birman (2000: 184)

Para ele, a autossuficiência é uma ilusão, uma pretensão com a marca do absurdo, uma vez que pressupóe um autocentramento, alimentado ao colocar o outro em uma posição de coisa. O que importa é o engrandecimento do 'eu' às custas do outro, em uma cena construída para o olhar, para o espetáculo.

Se acreditamos, como Wolf (2004), que a barbárie se refere a essa posição de fechamento ao diferente, a uma autossuficiência, à cultura do narcisismo de que nos fala Birman, desvenda-se um traço de barbárie da sociedade contemporânea que tende a negar a possibilidade da diferença e vê, no outro, na alteridade, algo que ameaça, algo a ser destruído, eliminado. Barbárie é não aceitar o outro como diferente. Esse traço tem consequências cotidianas que estampam todos os dias as páginas dos jornais: da violência urbana cotidiana à guerra no Oriente Médio. Há claros indícios de barbárie em nossa sociedade com sua economia globalizada.

Os valores que proponho neste processo civilizatório são, assim, contra-hegemônicos. Valores que, quando colocados em ato, revelam a nossa disposição para a convivência, para a aliança, para a mudança. Valores que se constroem e se transmitem na relação, nos encontros que estabelecemos nos nossos locais de trabalho, nas nossas ações de cuidado, de docência, pela vida. Valores que tomamos como inspiração. Valores que nos fazem exemplos. Valores que nos levam a construir redes, laços de "fraternidade", de "solidariedade". Birman (2000: 178) afirma:

podemos dizer que a ênfase recentemente colocada na experiência da fraternidade é uma espécie de antídoto face aos imperativos da cultura do narcisismo e da 
sociedade do espetáculo, na medida em que a categoria ética da fraternidade enuncia uma outra concepção possível de subjetividade. Nesta, com efeito, o outro importa para o sujeito e muito até, estando ambos no mesmo barco da existência.

Importância que nasce da clara consciência de nossa efemeridade, de nossa incompletude. Fomos lançados na aventura humana da existência, desarmados. A fraternidade pressupõe essa igualdade dos sujeitos, nessa viagem pelo tempo e pelo cosmos, fundada na precariedade.

\begin{abstract}
Portanto, a solidariedade é a consequência imediata da ética do laço fraterno. A solidariedade entre as pessoas é o que se manifesta no registro tangível das relaçóes humanas, como o desdobramento da fraternidade. Por isso mesmo, esta como ética implica necessariamente uma política, uma ação coletiva mediante a qual os laços sociais são tecidos pressupondo a mútua precariedade dos agentes e que visa justamente a impedir que a usurpação da igualdade possa de fato se efetivar. (Birman, 2000: 185-6)
\end{abstract}

Talvez possamos pensar na fraternidade e na solidariedade como valores promotores de bons encontros. Encontros que produzem efeitos, ressonâncias. Produzem alianças. Os atores e as ações da Reforma Psiquiátrica urdem esse entrelaçamento de desejos de pessoas isoladas que, em um determinado momento histórico, se transforma em processo social constituído de desejo e vontade coletiva, que vai implicando mais atores, ampliando sua atuação para diferentes campos. Como exemplaridade, podemos assinalar que a arte incorpora e participa desse processo, por meio do reconhecimento das obras produzidas pelos loucos, ou de livros e filmes.

O processo civilizador possui uma dimensão de caráter essencialmente histórico. Trata-se da construção do homem. Isso remete a uma outra dimensão, que é a do cotidiano, já apresentada no capítulo 3. É no cotidiano que se encena essa construção. Para Agnes Heller (1989: 17),

a vida cotidiana éa vida do homem inteiro; ou seja, o homem participa na vida cotidiana como todos os aspectos de sua individualidade, de sua personalidade. Nela, colocam-se "em funcionamento" todos os seus sentidos, todas as suas capacidades intelectuais, suas habilidades manipulativas, seus sentimento, idéias, ideologias. 
É no cotidiano que a Reforma Psiquiátrica inventa permanentemente as suas ações, que se produzem os encontros com o drama do existir, que se constroem estratégias de cuidado, que se organizam modos de habitar o mundo. Essa arte do cuidar, que se concretiza na produção constante, no fazer-acontecer, produz relações sociais norteadas pelos valores da solidariedade, da coletivização, criando resistência à conformação, à mesmice. Michel de Certeau (1994) chamou a isso de "reinvenção do cotidiano". Ele examina aspectos da história, construída no cotidiano por indivíduos que não são considerados protagonistas dos relatos históricos. Ele resgata o indivíduo como personagem central, o qual se apropria de ideias dominantes para as adequar à sua realidade, no sentido de viver e sobreviver nesse cotidiano já dado. É uma arte do fazer que desfaz, do construir desconstruindo.

Tal aspecto remete novamente ao pensamento de Agnes Heller, para a qual só quem tem necessidades radicais pode querer e fazer a transformação da vida. Somente pode desejar o impossível aquele para quem a vida cotidiana se tornou insuportável.

É nesse paradoxo e contradição do nosso cotidiano que talvez se possa encontrar a potência para construir caminhos de mudanças. A hipótese de Marx (1978: 329) de que "os homens fazem a sua própria história, mas não a fazem como querem; não a fazem sob circunstâncias de sua escolha e sim sob aquelas com que se defrontam diretamente, legadas e transmitidas pelo passado", apresenta-se como desafio a todos os que desejam transformar o mundo. O cenário é a vida de todo dia.

Para Ernst Bloch, a esperança tem uma função utópica, que é a de antecipar/vislumbrar o possível, o diferente, a liberdade. Olhar que vê, por entre as densas brumas matinais da mesmice cotidiana, a possibilidade do alvorecer de um novo amanhã e que o autor chama de "otimismo militante". Ele salienta:

Redobrando-se a coragem e o saber, o futuro não virá como fatalidade sobre o ser humano, mas o ser humano virá sobre o futuro e ingressará nele com o que é seu. Aqui o saber, que necessita da coragem e, sobretudo da decisão, não pode assumir a forma mais comum do saber habitual, a forma contemplativa, pois o saber meramente contemplativo se refere forçosamente ao que já está concluído e já passou, não tem mais meios diante de coisas presentes e é cego para o futuro. (Bloch, 2005: 196) 
Mais uma vez nos lembramos de Marx, a propósito da práxis. Trata-se não de contemplar o mundo, mas de transformá-lo. E quem o transforma também é transformado por ele. $\mathrm{O}$ futuro se coloca como um campo de possibilidades que nos convoca, que nos incita, que nos provoca a agir.

E, para que esse otimismo não seja aqui entendido como aspiração romântica, alienada das condições históricas concretas, reafirmo que não acredito que uma proposta contra-hegemônica, como a da Reforma Psiquiátrica, avance para a mudança do modelo assistencial em gestôes politicamente conservadoras. Neste caso, há um limite ideológico dos protagonistas que os impede de avançar, com interesses e visões de mundo diferentes. Mesmo Bloch (2005: 203) alerta, declarando que, "no caminho para o novo, geralmente - ainda que não sempre - deve-se proceder passo a passo. Nem tudo é possível e executável a qualquer hora: condições ausentes não só atrapalham como também chegam a impedir”.

Nossa utopia, nossa esperança aposta nesse infinito campo aberto de possibilidades que é o existir. Mudar o mundo é nosso devir. E a esperança, nosso princípio ético. Desconstruir/desfazer os dispositivos sociais que produzem os diferentes manicômios e inventar/construir/fazer, ao mesmo tempo, novos dispositivos sociais, que trazem não apenas os loucos como protagonistas centrais de sua história, mas toda essa gente excluída, os humildes, os humilhados, aqueles que não contam. Fazer acontecer pequenas revoluções cotidianas que ousam sonhar com uma sociedade diferente. A Reforma Psiquiátrica é assim, feita de rupturas e encontros. 


\section{REFERÊNCIAS}

ADORNO, T. W. \& HORKHEIMER, M. Dialética do Esclarecimento. Rio de Janeiro: Zahar, 1985.

ALMEIDA, M. C. Complexidade, do casulo à borboleta. In: CASTRO, G.; CARVALHO, E. A. \& ALMEIDA, M. C. (Orgs.) Ensaios de Complexidade. 3. ed. Porto Alegre: 2002.

ALMEIDA FILHO, N. A Ciência da Saúde. São Paulo: Hucitec, 2000.

ALVES, D. S. \& GULJOR, A. P. O cuidado em saúde mental. In: PINHEIRO, R. \& MATTOS, R. A. (Orgs.) Cuidado: as fronteiras da integralidade. São Paulo, Rio de Janeiro: Hucitec, Abrasco, 2004.

AMARANTE, P. O Homem e a Serpente: outras histórias para a loucura e a psiquiatria. Rio de Janeiro: Editora Fiocruz, 1996.

AMARANTE, P. Loucura, cultura e subjetividade: conceitos e estratégias, percursos e atores da reforma psiquiátrica brasileira. In: FLEURY, S. (Org.) Saúde e Democracia: a luta do Cebes. São Paulo: Lemos, 1997.

AMARANTE, P. (Coord.) Loucos pela Vida: a trajetória da Reforma Psiquiátrica no Brasil. Rio de Janeiro: Editora Fiocruz, 1998.

AMARANTE, P. Manicômio e loucura no final do século e do milênio. In: FERNANDES, M. I. (Org.) Fim de Século: ainda manicômios? São Paulo: Instituto de Psicologia da Universidade de São Paulo, 1999.

AMARANTE, P. A (clínica) e a reforma psiquiátrica. In: AMARANTE, P. (Coord.) Archivos de Saúde Mentale Atenção Psicossocial. Rio de Janeiro: Nau, 2003. 
AMARANTE, P. Saúde Mental e Atenção Psicossocial. Rio de Janeiro: Editora Fiocruz, 2007. ARAÚJO LIMA, E. M. F. Clínica e Criação: a utilização de atividades em instituiçôes de saúde mental, 1997. Dissertação de Mestrado em Psicologia Clínica, São Paulo: Pontifícia Universidade Católica.

ARAÚJO LIMA, E. M. F. Oficinas, laboratórios, ateliês, grupos de atividades: dispositivos para uma clínica atravessada pela criação. In: COSTA, C. M. \& FIGUEIREDO, A. C. (Orgs.) Oficinas Terapêuticas em Saúde Mental: sujeito, produção e cidadania. Rio de Janeiro: Contra Capa, 2004.

ARENDT, H. O que É Politica? 5. ed. Rio de Janeiro: Bertrand Brasil, 2004.

AROUCA, S. Sergio Arouca: o eterno guru da Reforma Sanitária (Entrevista). Radis: comunicação em saúde, 3(18-21), out. 2002.

AROUCA, S. O Dilema Preventivista: contribuiçôes para a compreensão e crítica da medicina preventiva. São Paulo, Rio de Janeiro: Editora Unesp, Editora Fiocruz, 2003.

AYRES, J. R. C. M. Sujeito, intersubjetividade e práticas de saúde. Ciência \& Saúde Coletiva, 6(1): 63-72, 2001.

BACHELARD, G. La Formation de l'Esprit Scientifique: contribution a une psychanalyse de la connaissance objetive. Paris: Librairie philosophique J. Vrin, 1967.

BACHELARD, G. O Novo Espírito Científico. 3. ed. Rio de Janeiro: Tempo Brasileiro, 2000.

BASAGLIA, F. A Psiquiatria Alternativa: contra o pessimismo da razão, o otimismo da prática. São Paulo: Brasil Debates, 1979.

BASAGLIA, F. \& BASAGLIA, F. O. Los Crímenes de la Paz. México: Siglo Veinteuno, 1977.

BEZERRA JR., B. Cidadania e loucura: um paradoxo? In: BENILTON, B. \&AMARANTE, P. (Orgs.) Psiquiatria sem Hospicio: contribuiçôes ao estudo da reforma psiquiátrica. Rio de Janeiro: Relume Dumará, 1992.

BEZERRA JR., B. A clínica e a reabilitação psicossocial. In: PITTA, A. (Org.) Reabilitação Psicossocial no Brasil. 2. ed. São Paulo: Hucitec, 1996.

BIRMAN, J. A Psiquiatria como Discurso da Moralidade. Rio de Janeiro: Graal, 1978.

BIRMAN, J. A cidadania tresloucada: notas introdutórias sobre a cidadania dos doentes mentais. In: BEZERRA JR, B. \& AMARANTE, P. (Orgs.) Psiquiatria sem Hospicio: contribuiçôes ao estudo da reforma psiquiátrica. Rio de Janeiro: Relume Dumará, 1992.

BIRMAN, J. Insuficientes, um esforço para sermos irmãos! In: KEHL, M. R. Função Fraterna. Rio de Janeiro: Relume Dumará, 2000.

BIRMAN, J. Mal-estar na Atualidade: a psicanálise e as novas formas de subjetivação. Rio de Janeiro: Civilização Brasileira, 2001.

BIRMAN, J. O mal-estar na modernidade e a psicanálise: a psicanálise à prova do social. Physis: Revista de Saúde Coletiva, 15, supl.: 203-224, 2005. 
BIRMAN, J. \& COSTA, J. F. Organizações e instituições para psiquiátrica comunitária. In: AMARANTE, P. (Org.) Psiquiatria Social e Reforma Psiquiátrica. Rio de Janeiro: Editora Fiocruz, 1994.

BLOCH, E. O Princípio Esperança. Rio de Janeiro: Contraponto, Eduerj, 2005. v. 1.

BOBBIO, N.; MATTEUCCI, N. \& PASQUINO, G. Dicionário de Política. Brasília, São Paulo: Editora UnB, Imprensa Oficial do Estado, 2000.

BOFF, L. Saber Cuidar: ética do humano-compaixão pela terra. Petrópolis: Vozes, 2002.

BRAGA, J. C. \& PAULA, S. G. Saúde e Previdência: estudos de politica social. São Paulo: Cebes, Hucitec, 1981.

BRASIL. Ministério da Saúde. I Conferência Nacional de Saúde Mental: relatório final/ 8 Conferência Nacional de Saúde. In: CONFERÊNCIA NACIONAL DE SAÚDE MENTAL, 2, 1988, Brasília. Coletânea de Textos... Brasília: Centro de Documentação do Ministério da Saúde, 1988.

BRASIL. Ministério da Saúde. Secretaria Nacional de Assistência à Saúde. Portaria n. 224. Brasília, 1992.

BRASIL. Ministério da Saúde. Relatório Final da $2^{a}$ Conferência Nacional de Saúde Mental. Brasília: Ministério da Saúde, Secretaria de Assistência à Saúde, Departamento de Assistência e Promoção à Saúde, Coordenação de Saúde Mental, 1994.

BRASIL. Ministério da Saúde. Secretaria Nacional de Assistência à Saúde. Portaria n. 336. Brasília, 2002.

CAMPINAS. Secretaria Municipal de Saúde. Relatório de Gestão 2001-2004. Campinas, dez. 2004. Disponível em: <www.campinas.sp.gov.br/saude>. Acesso em: 12 set. 2005.

CAMPOS, G. W. S. Reforma da Reforma: repensando a saúde. São Paulo: Hucitec, 1992.

CAMPOS, G. W. S. A Saúde Pública e a Defesa da Vida. São Paulo: Hucitec, 1994.

CAMPOS, G. W. S. Considerações sobre a arte e a ciência da mudança: revolução das coisas e reforma das pessoas - o caso da saúde. In: CECÍLIO, L. C. O. (Org.) Inventando a Mudança na Saúde. São Paulo: Hucitec, 1997.

CAMPOS, G. W. S. Um Método para Análise e Co-gestão de Coletivos. São Paulo: Hucitec, 2000.

CAMPOS, G. W. S. Saúde Paidéia. São Paulo: Hucitec, 2003.

CAMPOS, R. O. Clínica: a palavra negada - sobre as práticas clínicas nos serviços substitutivos de saúde mental. Saúde em Debate, 25(58): 98-111, 2001.

CAPLAN, G. Princípios de Psiquiatria Preventiva. Rio de Janeiro: Zahar, 1980.

CAPONI, S. Da Compaixão à Solidariedade: uma genealogia da assistência médica. Rio de Janeiro: Editora Fiocruz, 2000. 
CAPRA, F. O Ponto de Mutação. 25. ed. São Paulo: Cultrix, 2004.

CENTRO BRASILEIRO DE ESTUDOS DA SAÚDE (Cebes). A questão democrática na área da saúde. Revista Saúde em Debate, 9: 11-13, 1980.

CERQUEIRA, L. (Org.) Psiquiatria Social: problemas brasileiros de saúde mental. Rio de Janeiro: Atheneu, 1984.

CERTEAU, M. A Invenção do Cotidiano: as artes do fazer. Petrópolis: Vozes, 1994.

CHAUÍ, M. Cultura e Democracia: o discurso competente e outras falas. São Paulo: Moderna, 1980.

$\mathrm{COHN}, \mathrm{A}$. Estado e sociedade e as reconfigurações do direito à saúde. Ciência \& Saúde Coletiva, 8(1): 9-18, 2003.

CONSELHO REGIONAL DE PSICOLOGIA. 6a Região. Trancar Não É Tratar: liberdade éo melhor remédio. São Paulo, 1997. (Caderno de textos alusivos ao dia da Luta Antimanicomial).

CORBISIER, C. RIPP: quando escutar é preciso. Cadernos IPUB, VI(17): 59-69, 2000.

COSTA, C. M. \& FIGUEIREDO, A. C. (Orgs.) Oficinas Terapêuticas em Saúde Mental: sujeito, produção e cidadania. Rio de Janeiro: Contra Capa, 2004.

COSTA, J. F. História da Psiquiatria no Brasil: um corte ideológico. Rio de Janeiro: Campus, 1981.

COSTA, J. F. Narcisismo em tempos sombrios. In: BIRMAN, J. (Org.) Percursos na História da Psicanálise. Rio de Janeiro: Taurus, 1988.

COSTA-ROSA, A. Saúde Mental Comunitária: análise dialética das práticas alternativas, 1987. Dissertação de Mestrado em Psicologia Social, São Paulo: Instituto de Psicologia, Universidade de São Paulo.

COSTA-ROSA, A. O modo psicossocial: um paradigma das práticas substitutivas ao modo asilar. In: AMARANTE, P. (Org.) Ensaios: subjetividade, saúde mental e sociedade. Rio de Janeiro: Editora Fiocruz, 2000.

COSTA-ROSA, A.; LUZIO, C. \&YASUI, S. As Conferências Nacionais de Saúde Mental e as premissas do modo psicossocial. Saúde em Debate, 58: 12-25, 2001.

COSTA-ROSA, A.; LUZIO, C. \&YASUI, S. Atenção psicossocial: rumo a um novo paradigma na saúde mental coletiva. In: AMARANTE, P. (Coord.) Archivos de Saúde Mentale Atenção Psicossocial. Rio de Janeiro: Nau, 2003.

CUNHA, M. C. P. O Espelho do Mundo: Juquery, a história de um asilo. Rio de Janeiro: Paz e Terra, 1988.

DÂMASO, R. Saber e práxis na reforma sanitária: avaliação da prática cientifica no movimento sanitário. In:TEIXEIRA, S. F. (Org.) Reforma Sanitária: em busca de uma teoria. São Paulo: Cortez, 1995.

DEBORD, G. A Sociedade do Espetáculo: comentários sobre a sociedade do espetáculo. Rio de Janeiro: Contraponto, 1997. 
DELEUZE, G. Conversaçôes. Rio de Janeiro: Editora 34, 1992.

DELEUZE, G. Espinoza: filosofia prática. São Paulo: Escuta, 2002.

DELEUZE, G. \& GUATTARI, F. O Anti-Édipo: capitalismo e esquizofrenia. Rio de Janeiro: Imago, 1976.

DELGADO, P. G. G. As Razôes da Tutela: psiquiatria, justiça e cidadania do louco no Brasil. Rio de Janeiro: Te Corá, 1992.

DELL'ACQUA, G. \& MEZZINA, R. Resposta à crise. In: AMARANTE, P. (Org.) Archivos de Saúde Mentale Atenção Psicossocial2. Rio de Janeiro: Nau, 2005.

DERRIDA, J. A Farmácia de Platão. São Paulo: Iluminuras, 1997.

ELIAS, N. O Processo Civilizador: formação do Estado e civilização. Rio de Janeiro: Zahar, 1993.

ESCOREL, S. Saúde: uma questão nacional. In: TEIXEIRA, S. F. (Org.) Reforma Sanitária: em busca de uma teoria. São Paulo: Cortez, 1995.

ESCOREL, S. Reviravolta na Saúde: origem e articulação do movimento sanitário. Rio de Janeiro: Editora Fiocruz, 1998.

FIGUEIREDO, G. R. A Evolução do Hospício no Brasil, 1996. Tese de Doutorado em Medicina, São Paulo: Escola Paulista de Medicina, Universidade Federal de São Paulo.

FLEMING, M. Ideologia e Práticas Psiquiátricas. Porto: Afrontamento, 1976.

FLEURY, S. A questão democrática da saúde. In: FLEURY, S. (Org.) Saúde e Democracia: a luta do CEBES. São Paulo: Lemos, 1997.

FOUCAULT, M. Doença Mentale Psicologia. Rio de Janeiro: Tempo Brasileiro, 1975.

FOUCAULT, M. História da Loucura na Idade Clássica. São Paulo: Perspectiva, 1978.

FOUCAULT, M. Microfisica do Poder. Rio de Janeiro: Graal, 1979.

FOUCAULT, M. Vigiar e Punir. Petrópolis: Vozes, 1983.

FOUCAULT, M. Nascimento da Clinica. 3. ed. Rio de Janeiro: Forense-Universitária, 1987.

FOUCAULT, M. A Verdade e as Formas Jurídicas. 3. ed. Rio de Janeiro: Nau, 2003.

FOUCAULT, M. A Ordem do Discurso. 10. ed. São Paulo: Loyola, 2004.

FRANCO, T. B.; BUENO, W.S. \& MERHY, E. E. O acolhimento e os processos de trabalho em saúde: o caso de Betim, Minas Gerais, Brasil. Cadernos de Saúde Pública, 15(2):345-353, 1999.

FREIRE, F. H. M. A. O Sistema de Alocação de Recursos do SUS aos Centros de Atenção Psicossocial: implicaçôes com a proposta de atuação dos serviços substitutivos, 2004. Dissertação de Mestrado em Saúde Pública, Rio de Janeiro: Escola Nacional de Saúde Pública Sérgio Arouca, Fundação Oswaldo Cruz.

FREIRE, P. Pedagogia da Esperança: um reencontro com a pedagogia do oprimido. São Paulo: Paz eTerra, 1992. 
FREIRE, P. Pedagogia dos Sonhos Possiveis. São Paulo: Editora Unesp, 2001.

FREITAG, B. Teoria Crítica: ontem e hoje. São Paulo: Brasiliense, 1994.

FREUD, S. Uma Dificuldade no Caminho da Psicanálise [1917]. Edição standard brasileira das obras psicológicas completas de Sigmund Freud. Rio de Janeiro: Imago, 1980a. v. XVII.

FREUD, S. Mal-Estar na Civilização [1930]. Edição standard brasileira das obras psicológicas completas de Sigmund Freud. Rio de Janeiro: Imago, 1980b. v. XXI.

GALLETTI, M. C. Oficina em Saúde Mental: instrumento terapêutico ou intercessor clinico?, 2001. Dissertação de Mestrado em Psicologia Clínica, São Paulo: Pontifícia Universidade Católica.

GERSCHMAN, S. A Democracia Inconclusa: um estudo da Reforma Sanitária brasileira. 2. ed. Rio de Janeiro: Editora Fiocruz, 2004.

GIOVANELLA, L. \& AMARANTE, P. O enfoque estratégico do planejamento em saúde e saúde mental. In: AMARANTE, P. (Org.) Psiquiatria Social e Reforma Psiquiátrica. Rio de Janeiro: Editora Fiocruz, 1994.

GOFFMAN, E. Manicômios, Prisóes e Conventos. São Paulo: Perspectiva, 1974.

GOLDBERG, J. Clínica da Psicose: um projeto na rede pública. 2. ed. Rio de Janeiro: Te Corá, 1996.

GOLDBERG, J. Cotidiano e Instituição: revendo o tratamento de pessoas com transtorno mental em instituiçôes públicas, 1998. Tese de Doutorado, São Paulo: Faculdade de Medicina, Universidade de São Paulo. v. 1.

GRANON-LAFONT, J. La Topologie Ordinaire de Jacques Lacan. Paris: Point Hors Ligne, 1988.

GUATTARI, F. Revolução Molecular: pulsaçõespolíticas do desejo. São Paulo: Brasiliense, 1981.

GUATTARI, F. Caosmose: um novo paradigma estético. São Paulo: Editora 34, 1992.

GUATTARI, F. \& ROLNIK, S. Micropolitica: cartografias do desejo. 7. ed. Petrópolis: Vozes, 2005.

GULLAR, F. Dentro da Noite Veloz. São Paulo: Círculo do livro, s. d.

HABERMAS, J. Técnica e ciência enquanto ideologia. In: Textos Escolhidos: Walter Benjamim, Max Horkheimer, Theodor W. Adorno, Jungen Habermas. São Paulo: Abril, 1980. (Coleção Os Pensadores).

HELLER, A. O Cotidiano e a História. São Paulo: Paz e Terra, 1989.

HORTALE, V. A.; PEDROZA, M. \& ROSA, M. L. G. Operacionalizando as categorias acesso e descentralização na análise de sistemas de saúde. Cadernos de Saúde Pública, 16(1):231-239, 2000.

HOUAISS, A. Dicionário Houaiss da Lingua Portuguesa. Rio de Janeiro: Objetiva, 2001. 
JACOBI, P. Movimentos Sociais e Políticas Públicas. São Paulo: Cortez, 1989.

JAPIASSU, H. Para Ler Bachelard. Rio de Janeiro: Francisco Alves, 1976a.

JAPIASSU, H. Interdisciplinaridade e Patologia do Saber. Rio de Janeiro: Imago, $1976 \mathrm{~b}$.

KEHL, M. R. Civilização partida. In: NOVAES, A. (Org.) Civilização e Barbárie. São Paulo: Companhia das Letras, 2004.

KINOSHITA, R. T. Em busca da cidadania. In: CAMPOS, F. C. B. \& HENRIQUES, C. M. P. (Orgs.) Contra a Maréà Beira-Mar. São Paulo: Hucitec, 1997.

KODA, M. Y. Da Negação do Manicômio à Construção de um Modelo Substitutivo em Saúde Mental: o discurso de usuários e trabalhadores de um núcleo de atenção psicossocial, 2002. Dissertação de Mestrado, São Paulo: Instituto de Psicologia, Universidade de São Paulo.

KUBRUSLY, R. S. Paradoxo \& Matemática \& Psicanálise (ou Um Pato Fora d’Água). Disponível em: <www.dmm.im.ufrj.br/ risk/Site_AI/matematica.htm>. Acesso em: 1 jun. 2005.

KUCZYNSKI, P. P. \& WILLIAMSON, J. After the Washington Consensus: restarting growth and reform in Latin America. Washington: Institute for International Economics, 2003. Disponível em: $<$ http://bookstore.iie.com/merchant.mvc?Screen=PROD\&Product_Code=350: Acesso em: 19 jul. 2005.

KUHN, T. A Estrutura das Revoluções Cientificas. São Paulo: Perspectiva, 2000.

LANCETTI, A. Prevenção, preservação e progresso em saúde mental. In: LANCETTI, A. (Org.) Saudeloucura. São Paulo: Hucitec, 1989. v. 1.

LASCH, C. A Cultura do Narcisismo: a vida americana numa era de esperanças em declínio. Rio de Janeiro: Imago, 1983.

LEVCOVITZ, E.; LIMA, L. D. \& MACHADO, C. V. Política de saúde nos anos de 90: relaçôes intergovernamentais e o papel da Normas Operacionais Básicas. Ciência e Saúde Coletiva, 6(2): 269-291, 2001.

LOBOSQUE, A. M. Princípios para uma Clínica Antimanicomiale Outros Escritos. São Paulo: Hucitec, 1997.

LUZ, M. T. Duas questôes permanentes em um século de políticas de saúde no Brasil republicano. Ciência e Saúde Coletiva, 5(2): 293-312, 2000.

LUZ, M. T. Natural, Racional, Social: razão médica e racionalidade cientifica moderna. 2. ed. São Paulo: Hucitec, 2004.

MACHADO, R. Ciência e Saber: a trajetória da arqueologia de Michel Foucault. 2. ed. Rio de Janeiro: Graal, 1988.

MACHADO, R. et al. Danação da Norma: medicina social e constituição da psiquiatria no Brasil. Rio de Janeiro: Graal, 1978.

MARCUSE, H. Ideologia da Sociedade Industrial. Rio de Janeiro: Zahar, 1969. 
MARTINS, J. S. A Sociabilidade do Homem Simples: o cotidiano e história na modernidade anômala. São Paulo: Hucitec, 2000.

MARX, K. O 18 Brumário de Luís Bonaparte. In: MARX, K. Manuscritos Econômicos-Filosóficos e Outros Textos Escolhidos. 2. ed. São Paulo: Abril Cultural, 1978. (Coleção Os Pensadores).

MATTOS, R. A. Cuidado prudente para uma vida decente. In: PINHEIRO, R. \& MATTOS, R. A. (Orgs.) Cuidado: as fronteiras da integralidade. São Paulo, Rio de Janeiro: Hucitec, Abrasco, 2004.

MERHY, E. E. Saúde: a cartografia do trabalho vivo. São Paulo: Hucitec, 2002.

MERHY, E. E. \& FRANCO, T. B. Por uma composição do trabalho em saúde centrada no campo relacional e nas tecnologias leves: apontando mudanças para os modelos tecnoassistenciais. Saúde em Debate: Revista do Centro Brasileiro de Estudos da Saúde, 27(64): 316323, 2003.

MORIN, E. Ciência com Consciência. 6. ed. Rio de Janeiro: Bertrand Brasil, 2002.

MORIN, E. A necessidade de um pensamento complexo. In: MENDES, C. \& LARRETA, E. (Orgs.) Representação e Complexidade. Rio de Janeiro: Garamond, 2003.

NICÁCIO, M. F. O Processo de Transformação da Saúde Mental em Santos: desconstrução de saberes, instituiçôes e cultura, 1994. Dissertação de Mestrado em Ciências Sociais, São Paulo: Pontifícia Universidade Católica de São Paulo.

NORONHA, J. C. \& LEVCOVITZ, E. AIS-SUDS-SUS: os caminhos do direito à saúde. In: GUIMARÃES, R. \& TAVARES, R. (Orgs.) Saúde e Sociedade no Brasil: anos 80. Rio de Janeiro: Abrasco, IMS-Uerj, Relume Dumará, 1997.

NOVAES, A. (Org.) Civilização e Barbárie. São Paulo: Companhia das Letras, 2004.

OLIVEIRA, J. A. A. \&TEIXEIRA, S. M. F. A (Im)Previdência Social Brasileira. Rio de Janeiro: Abrasco, Vozes, 1986.

PAIM, J. S. Bases conceituais da reforma sanitária brasileira. In: FLEURY, S. (Orgs.) Saúde e Democracia: a luta do Cebes. São Paulo: Lemos, 1997.

PAIM, J. S. \& ALMEIDA FILHO, N. Saúde coletiva: uma 'nova saúde pública' ou campo aberto a novos paradigmas? Revista de Saúde Pública, 32(4): 299-316, 1998.

PASSOS, E. \& BARROS, R. B. A construção do plano da clínica e o conceito de transdisciplinariedade. Psicologia: Teoria e Pesquisa, 16(1): 71-79, 2000.

PELBART, P.P. A Nau do Tempo-Rei: sete ensaios sobre o tempo da loucura. Rio de Janeiro: Imago, 1993.

PRIGOGINE, I. O Fim das Certezas: tempo, caos e leis da natureza. São Paulo: Editora Unesp, 1996.

PRIGOGINE, I. \& STENGERS, I. Entre o Tempo e a Eternidade. São Paulo: Companhia das Letras, 1992. 
PRIGOGINE, I. \&STENGERS, I. A Nova Aliança. Brasília: Editora da UnB, 1997.

RAUTER, C. Oficinas para quê? Uma proposta ético-estético-política para oficinas terapêuticas. In: AMARANTE, P. (Org.) Ensaios: subjetividade, saúde mental, sociedade. Rio de Janeiro: Editora Fiocruz, 2000.

RESENDE, H. Políticas de saúde mental no Brasil: uma visão histórica. In: TUNDIS, S. A. \& COSTA, N. R. (Orgs.) Cidadania e Loucura: politicas de saúde mental no Brasil. Rio de Janeiro: Vozes, 1987.

ROLNIK, S. Cartografia Sentimental: transformaçôes contemporâneas do desejo. São Paulo: Estação Liberdade, 1989.

ROSA, J. G. Grande Sertão: veredas. 18. ed. Rio de Janeiro: Nova Fronteira, 1985.

ROTELLI, F; LEONARDI, O. \& MAURI, D. Desinstitucionalização: uma outra via. In: NICÁCIO, F. (Org.) Desinstitucionalização. São Paulo: Hucitec, 2001.

SADER, E. Quando Novos Personagens Entraram em Cena: experiências, falas e lutas dos trabaIhadores da Grande São Paulo (1970-1980). 3. reimp. Rio de Janeiro: Paz e Terra, 1995.

SANTOS, B. S. Um Discurso sobre as Ciências. Porto: Afrontamento, 1987.

SANTOS, B. S. Para um Novo Senso Comum: a ciência, o direito e a politica na transição paradigmática. São Paulo: Cortez, 2001.

SANTOS, B. S. (Org.) Conhecimento Prudente para uma Vida Decente: 'um discurso sobre as ciências' revisitado. São Paulo: Cortez, 2004.

SANTOS, M. O País Distorcido. São Paulo: Publifolha, 2002.

SARACENO, B. Reabilitação psicossocial; uma estratégia para a passagem do milênio. In: PITTA, A. (Org.) Reabilitação Psicossocial no Brasil. São Paulo: Hucitec, 1996.

SARACENO, B. Libertando Identidades: da reabilitação psicossocial à cidadania possível. Belo Horizonte, Rio de Janeiro: Te Corá, Instituto Franco Basaglia, 1999.

SISTEMA ÚNICO DE SAÚDE (SUS)/CONSELHO NACIONAL DE SAÚDE(CNS). Comissão Organizadora da III CNSM. Relatório Final da III Conferência Nacional de Saúde Mental. Brasilia, 11 a 15 de dezembro de 2001. Brasília: Conselho Nacional de Saúde, Ministério da Saúde, 2002.

SMITH, A. A Riqueza das Nações: investigação sobre sua natureza e suas causas. São Paulo: Nova Cultural, 1988. (Coleção Os Pensadores).

SOUZA, R. R. Redução das desigualdades regionais na alocação dos recursos federais para a saúde. Ciência \& Saúde Coletiva, 8(2): 264-460, 2003.

STOTZ, E. N. Movimentos sociais e saúde: notas para uma discussão. Cadernos de Saúde Pública, 10(2): 264-268, 1994.

TEIXEIRA, S. F. (Org.) Reforma Sanitária: em busca de uma teoria. São Paulo: Cortez, 1995. 
TEIXEIRA, S. F. \& MENDONÇA, M. H. Reformas sanitárias na Itália e no Brasil: comparações. In: TEIXEIRA, S. F. (Org.) Reforma Sanitária: em busca de uma teoria. São Paulo: Cortez, 1995.

TELLES, V. S. Movimentos sociais: reflexões sobre a experiência dos anos 70. In: SCHERERWARREN, I. \& KRISCHKE, P. J. (Orgs.) Uma Revolução no Cotidiano? Os novos movimentos sociais na América Latina. São Paulo: Brasiliense, 1987.

TENÓRIO, F. Da reforma psiquiátrica à clínica do sujeito. In: QUINET, A. (Org.) Psicanálise e Psiquiatria: controvérsias e convergências. Rio de Janeiro: Rio Ambiciosos, 2001.

TOBAR, F. E. \&YALOUR, M. R. Como Fazer Teses em Saúde Pública: conselhos e idéias para formular projetos e redigir tese e informes de pesquisa. Rio de Janeiro: Editora Fiocruz, 2001.

TOURAINE, A. Crítica da Modernidade. 7. ed. Petrópolis: Vozes, 2002.

UNGLERT, C. V. S. Territorialização em sistemas de saúde. In: MENDES, E. V. (Org.) Distrito Sanitário: o processo social e mudança das práticas sanitárias do Sistema Único de Saúde. São Paulo: Hucitec, 1993.

VASCONCELOS, E. M. Complexidade e Pesquisa Interdisciplinar: epistemologia e metodologia operativa. Petrópolis: Vozes, 2002.

WEBER, M. A Ética Protestante e o Espirito do Capitalismo. São Paulo: Companhia das Letras, 2004.

WILLIAMSON, J. Latin American Adjustment: how much has happened? Washington: Institute for International Economics, 1990. Disponível em: <http:/www.iie.com/publications/papers/ paper.cfm?ResearchID=486>. Acesso em: 19 jul. 2005.

WILLIAMSON, J. Our agenda and the Washington consensus. In: KUCZYNSKI, P. P. \& WILLIAMSON, J. (Eds.) After the Washington Consensus: restarting growth and reform in Latin America. Washington: Institute for International Economics, 2003. Disponível em: <http:// bookstore.iie.com/merchant.mvc?Screen=PROD\&Product_Code=350>. Acesso em: 19 jul. 2005.

WOLF, F. Quem é bárbaro. In: NOVAES, A. (Org.) Civilização e Barbárie. São Paulo: Companhia das Letras, 2004.

YASUI, S. Construção da Reforma Psiquiátrica e o seu Contexto Histórico, 1999. Dissertação de Mestrado em Psicologia e Sociedade, Assis: Faculdade de Ciências e Letras de Assis, Universidade Estadual Paulista. 

Formato: $16 \times 23 \mathrm{~cm}$

Tipologia: AGaramond e ZapfHumnst BT

Papel: Pólen Bold 70g $/ \mathrm{m}^{2}$ (miolo)

Cartão Supremo $250 \mathrm{~g} / \mathrm{m}^{2}$ (capa)

Impressão e acabamento: Imprinta Express Gráfica e Editora Ltda.

Rio de Janeiro, julho de 2010

Não encontrando nossos títulos em livrarias,

contactar a EDITORA FIOCRUZ:

Av. Brasil, 4036 - 1ํo andar - sala 112 - Manguinhos

21040-361 - Rio de Janeiro - RJ

Tel.: (21) 3882-9039 e 3882-9006

Telefax: (21) 3882-9007

www.fiocruz.br/editora

editora@fiocruz.br 
Os estudos sobre loucura, processo saúde/doença mental, reforma psiquíátrica, subjetividade e comportamento humano conformam um vasto campo de conhecimentos que tem sido objeto de inúmeras áreas de saber. A natureza das questões envolvidas fazem deste campo um dos mais interdisciplinares e complexos dos tempos atuais, tamanha a diversidade de disciplinas que dele se ocupam (antropologia, sociologia, história, filosofia, psicanálise, psicologia, psiquiatria, dentre outros), e que, não obstante, requerem ainda permanentes rupturas nas fronteiras e territórios de tais saberes.

No Brasil, principalmente nos últimos anos, tais estudos vêm merecendo uma atenção e um debate visivelmente crescentes.

Não apenas nos centros acadêmicos, mas também no âmbito dos serviços e da cultura, na medida em que nosso país vem sendo palco de um dos mais importantes processos de transformação na área da saúde mental.

A coleção Loucura \& Civilização propõe-se a contribuir nesse debate e nessa produção, reunindo livros e coletâneas dos mais expressivos autores nacionais e internacionais que têm como objetivo não apenas qualificar o debate e a produção teórica, mas também a construção de novas formas sociais e técnicas no lidar com a loucura, a doença mental e o sofrimento humano. 